Universidade de São Paulo

Faculdade de Economia, Administração e Contabilidade

Departamento de Contabilidade e Atuária

\title{
DEMONSTRAÇÃO CONTÁBIL DO VALOR ADICIONADO - DVA - UM INSTRUMENTO DE MENSURAÇÃO DA DISTRIBUIÇÃO DA RIQUEZA DAS EMPRESAS PARA OS FUNCIONÁRIOS
}

Jacqueline Veneroso Alves da Cunha

São Paulo, 2002 
Universidade de São Paulo

Faculdade de Economia, Administração e Contabilidade

Departamento de Contabilidade e Atuária

\section{DEMONSTRAÇÃO CONTÁBIL DO VALOR ADICIONADO - DVA - UM INSTRUMENTO DE MENSURAÇÃO DA DISTRIBUIÇÃO DA RIQUEZA DAS EMPRESAS PARA OS FUNCIONÁRIOS}

Jacqueline Veneroso Alves da Cunha

Dissertação apresentada à Faculdade de Economia, Administração e Contabilidade da Universidade de São Paulo, para obtenção do título de Mestre em Controladoria e Contabilidade

Orientadora: Profa. Dra. Maisa de Souza Ribeiro

São Paulo, 2002 
Dedico este trabalho à minha filha Patrícia, meu marido Sávio, e a meus pais Maria Tereza e Onésimo, grandes amores da minha vida. 


\section{AGRADECIMENTOS}

A Deus, pelo dom da vida e por colocar no meu caminho pessoas tão especiais.

À minha filha Patrícia, que sempre compreendeu meus momentos de ausência e por entender a importância desta etapa na minha vida.

Ao meu marido Sávio, grande companheiro de todos os momentos, pelo apoio incondicional e por não me deixar desistir nunca.

Aos meus pais, por me ensinarem a acreditar, confiar e lutar pelos meus ideais. E por terem acreditado, confiado e lutado junto comigo.

À Glória, Eustáquio, Bruno e Flávio, que me receberam em sua casa em São Paulo, durante a minha permanência na cidade para conclusão do mestrado.

Ao Nelson e à Professora Valéria, grandes incentivadores e amigos.

À Professora Dra. Maisa de Souza Ribeiro, por aceitar ao convite de me orientar neste trabalho, mesmo sem me conhecer, e tê-lo feito com tanta sabedoria, competência e brilhantismo, mas principalmente com humildade, generosidade, entusiasmo e dedicação.

Ao Unicentro Newton Paiva, na pessoa dos seus diretores, por propiciarem apoio financeiro para a realização deste trabalho.

Ao Professor Carlos Joarestes das Graças Ferreira, pela amizade, incentivo e confiança em minha capacidade.

À FIPECAFI que, na pessoa do Professor Dr. Ariovaldo dos Santos, disponibilizou seu banco de dados para minha pesquisa. 
À Maria Lúcia - Malu - que secretariou o Programa de Mestrado e me acolheu com tanta amizade durante minha permanência na FEA/USP.

Aos Professores Drs. Gilberto de Andrade Martins e Luiz João Corrar, que durante a elaboração deste trabalho me auxiliaram sobre a melhor forma de sua apresentação e sobre as técnicas estatísticas que poderiam ser nele empregadas.

Aos Professores Drs. Ariovaldo dos Santos e Fernanda Gabriela Borger, que participaram da minha banca de qualificação e contribuíram para aumentar a qualidade desta dissertação.

A todos os professores dos quais tive o privilégio de ser aluna durante o Mestrado.

A todos os meus colegas de mestrado, pela convivência e, ainda que alguns tenham ficado no meio do caminho, pelo incentivo para continuar. 


\section{RESUMO}

A contabilidade, como veículo de informação, tem como um de seus grandes desafios colocar, à disposição de seus usuários, informações que retratem as relações das empresas com a sociedade. O Balanço Social, no todo, e a Demonstração do Valor Adicionado - DVA - como uma de suas vertentes, se apresentam como os instrumentos capazes de evidenciar tanto os aspectos econômicos, quanto os sociais, inovando o enfoque utilizado até então, e se constituindo nos mais ricos demonstrativos para aferição dessas relações. Entretanto, nenhum deles, apesar do poder informativo que possuem, vem sendo utilizado da forma esperada. Desmistificando o que vem sendo propagado, a realidade é que a utilização do Balanço Social e da DVA está muito aquém do desejado, seja no Brasil ou em âmbito internacional. Dessa forma, o principal objetivo deste estudo foi a realização de uma pesquisa junto a 198 empresas, retiradas do cadastro mantido pela FIPECAFI para edição anual de Melhores e Maiores da Revista Exame. Nessa pesquisa procurou-se avaliar o poder de aferição representado pela DVA, no que concerne a informações sobre a formação de riqueza pelas empresas e sua distribuição aos agentes econômicos que ajudaram a criá-la, como proprietário, sócios e acionistas, governo, financiadores externos, empregados e a própria empresa. Especificamente buscou-se, pelas informações prestadas na DVA, avaliar a relação existente entre a variação da riqueza criada e a remuneração paga aos funcionários. Algumas constatações foram possíveis durante a realização desse estudo, dentre elas: de 1996 a 2000 - período analisado - o número médio de pessoas empregadas nas empresas participantes da amostra, apresentou queda tanto no ramo industrial quanto no de serviços, onde se constatou a maior oscilação negativa no valor adicionado distribuído por empregado; dentro de um mesmo ano, as empresas consideradas como maiores criadoras de riqueza, não participaram do rol daquelas que mais distribuíram valor adicionado a empregados; em algumas empresas, setores ou ramos de atividade, a relação entre a evolução da riqueza e do valor adicionado distribuído por empregado se apresentou negativa, demonstrando que, enquanto uma das variáveis aumentava, com a outra ocorria exatamente o oposto. Ao final do estudo tornou-se possível afirmar que os indicadores retirados da DVA constituem-se num excelente avaliador da distribuição da riqueza, à disposição da contabilidade, no entanto sem nenhuma pretensão em substituir, ou até mesmo rivalizar, outros indicadores de riqueza já existentes. 


\section{ABSTRACT}

Making available to its users information about the relations between companies and society is one of the great challenges for Accounting as an information vehicle. The Social Balance Sheet in general and the Statement of Value Added - SVA - as one of its complements appear as the instruments capable of demonstrating the economic as well as social aspects, thus innovating on what had been focused until then, which turns them into the richest statements for verifying these relations. Nevertheless, in spite of their informative power, none of them has been used as expected. Demystifying what is said about them, actually, the use of the Social Balance Sheet and the SVA does not correspond to what is desired, neither in Brazil nor abroad. Thus, a research was realized in 198 companies that were taken from FIPECAFI's "Melhores e Maiores" database for the Magazine Exame. This survey aimed to evaluate the verifying power of the SVA with respect to information about companies' wealth formation and its distribution to those economic agents that helped to create it, such as proprietors, partners and shareholders, government, external financiers, employees and the company itself. Through the information provided in the SVA, a specific attempt was made to evaluate the existing relation between the variation in created wealth and employees' remuneration. During this study, some observations could be made, such as: between 1996 and 2000 - which is the period under analysis - the average amount of employees in the companies that made up the sample fell in the industrial as well as service areas, which demonstrated the highest negative variation in value added distributed to the employees; in one and the same year, the companies considered as the largest wealth generators were no part of the list of those companies that most distributed value added to employees; in some companies, sectors or activity fields, the relation between wealth evolution and distributed value added per employee turned out negative, which demonstrates that, while one of the variables increased, the other revealed exactly the opposite behavior. At the end of the study, it could be affirmed that the indicators taken from the SVA make up an excellent means of evaluating wealth distribution, which is available to accounting, although without any intent to substitute or even compete with other, already existing wealth indicators. 


\section{SUMÁRIO}

LISTA DE FIGURAS.....................................................................................IX

LISTA DE GRÁFICOS................................................................................

LISTA DE TABELAS ......................................................................................... XII

INTRODUÇÃO ...........................................................................................

CAPÍTULO 1 - O PROBLEMA DE PESQUISA ........................................................

$1.1 \quad$ Identificação do Problema............................................................................

1.1.1 O papel da contabilidade ...................................................................

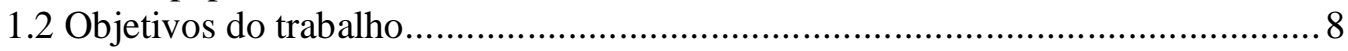

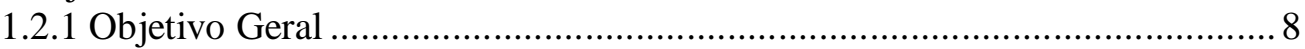

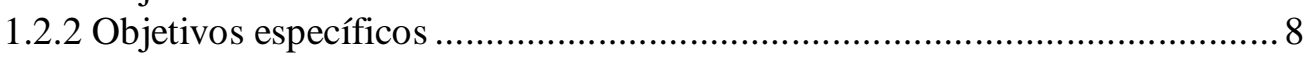

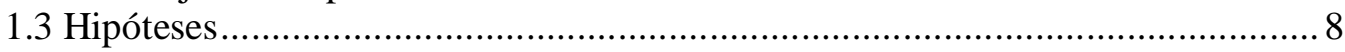

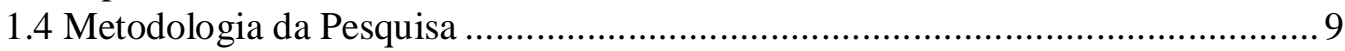

1.5 Estrutura do trabalho ……………………………………………………... 10

CAPÍTULO 2 - REVISÃO DA BIBLIOGRAFIA ………….............................12

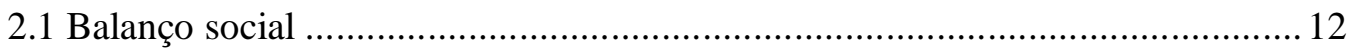

2.1.1 Aspectos conceituais ............................................................................. 14

2.1.2 O primeiro balanço social no mundo - o francês............................................ 17

2.1.3 O balanço social em outros países do mundo................................................ 19

2.1.4 O balanço social no Brasil.......................................................................2

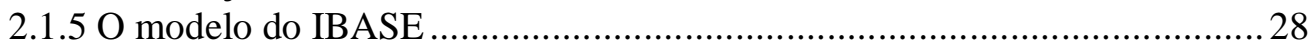

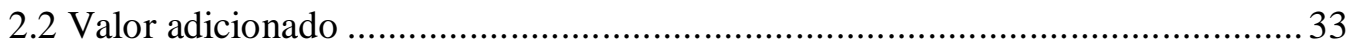

2.2.1 Conceito econômico ………………………………………………..........

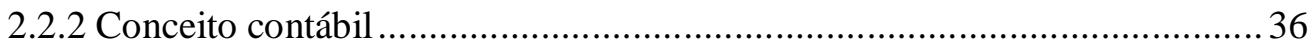

2.2.3 Demonstração do Valor Adicionado........................................................... 41

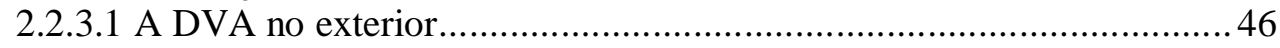

2.2.3.2 Exemplos de DVA publicadas por empresas no exterior........................50

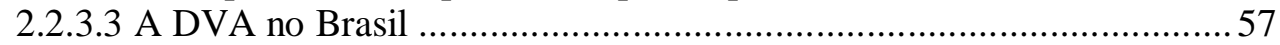

2.3 Renda

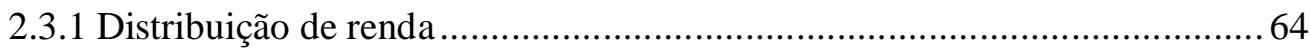

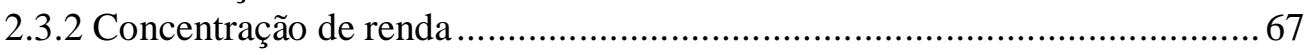

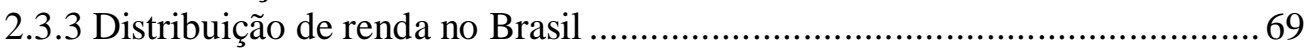

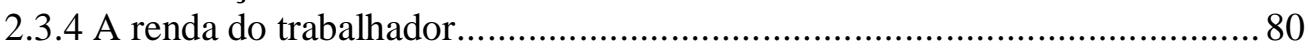

CAPÍTULO 3 - ASPECTOS PRÁTICOS DA DVA …………………………........85

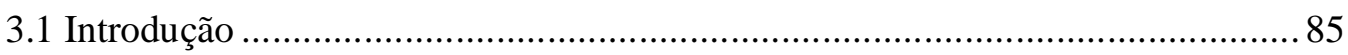

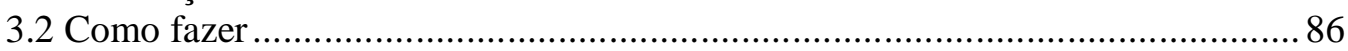

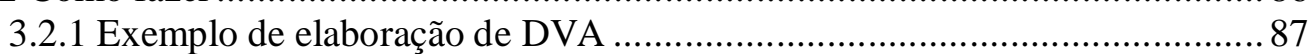

3.3 Tratamento de alguns dos elementos que compõem a DVA …………………....92

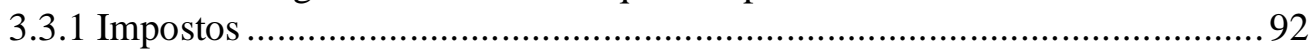

3.3.2 Vendas de mercadorias, produtos e serviços.............................................. 93

3.3.3 Provisão para devedores duvidosos - reversão/constituição...........................94

3.3.4 Depreciação, amortização e exaustão. ...................................................94

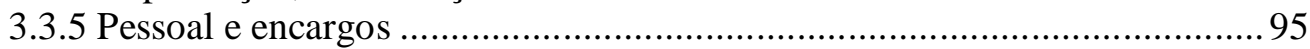

3.3.6 Remuneração do capital ..............................................................................96 
3.3.7 Receita financeira e receita de equivalência patrimonial............................97

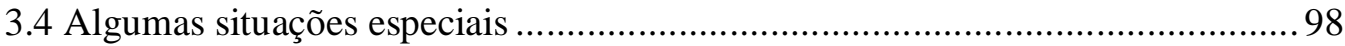

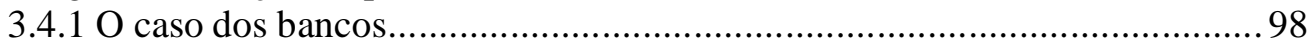

3.4.2 Empresas com prejuízos contábeis e/ou valor adicionado negativo.............99

CAPÍTULO 4 - PLANEJAMENTO E COLETA DOS DADOS........................101

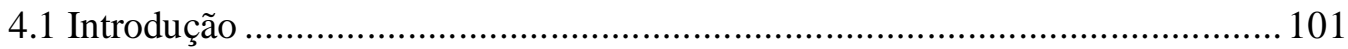

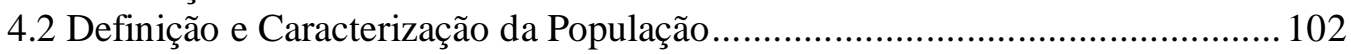

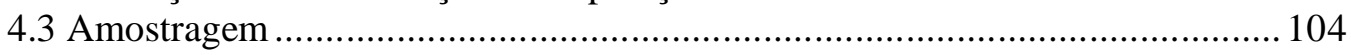

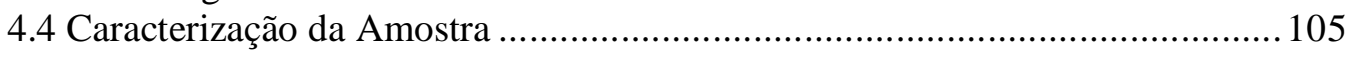

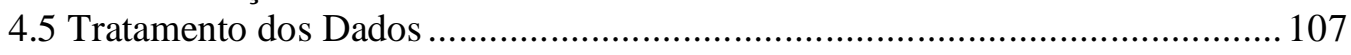

CAPÍTULO 5 - ANÁLISE DOS RESULTADOS ...................................................108

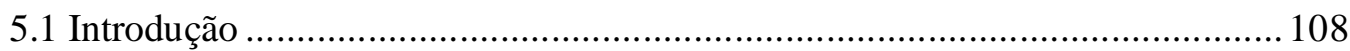

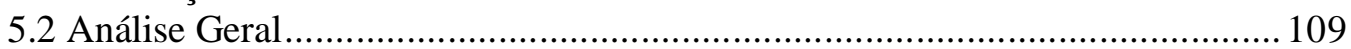

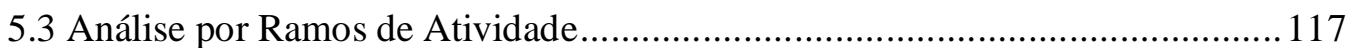

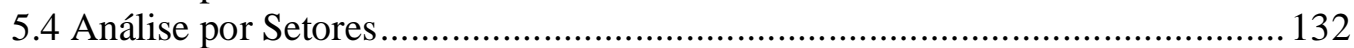

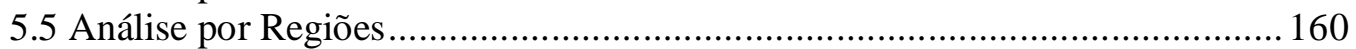

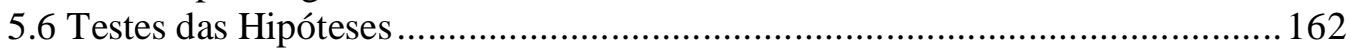

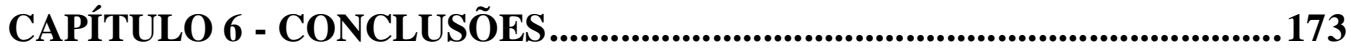

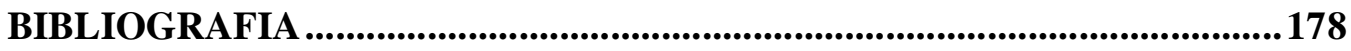

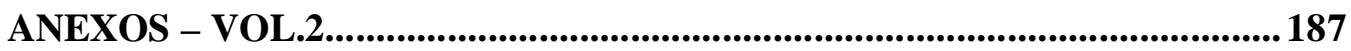

Anexo A - Modelo de balanço social francês .................................................... 188

Anexo B - Modelo de balanço social chileno ...................................................2234

Anexo C - Modelo de balanço social belga ......................................................2238

Anexo D - Modelo de balanço social português ..................................................2241

APÊNDICES - VOL.2 …...................................................................................2254

Apêndice A - Quadros e tabelas ................................................................. 255 


\section{LISTA DE FIGURAS}

Figura 1 - Modelo de balanço social do IBASE e instruções de preenchimento .......30

Figura 2- DVA da Lakeland Dairies Co-Operative Society Ltd. - 2000 .................. 51

Figura 3 - DVA da Times Publishing Limited - 30-09-2000 .................................. 52

Figura 4 - DVA da Allied Electronics Corporation Limited - Altron - 2001 ........... 54

Figura 5 - DVA da Gold Fields Limited - 2001 .................................................. 55

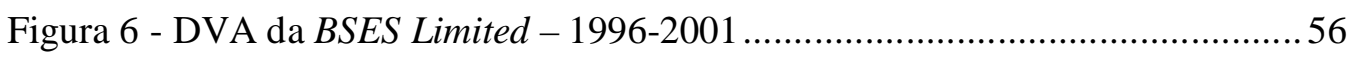

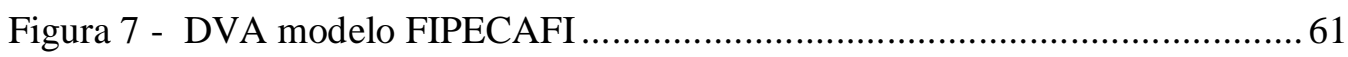

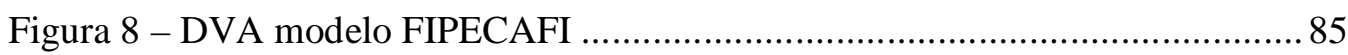

Figura 9 - Demonstração do Resultado do Exercício................................................ 88

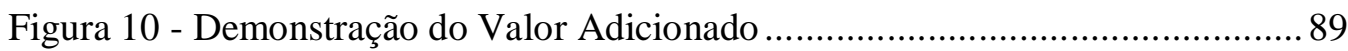




\section{LISTA DE GRÁFICOS}

Gráfico 1- Distribuição do valor adicionado em 1996 ..........................................110

Gráfico 2 - Distribuição do valor adicionado em 1997 ......................................... 110

Gráfico 3 - Distribuição do valor adicionado em 1998 ........................................ 111

Gráfico 4 - Distribuição do valor adicionado em 1999 ......................................... 111

Gráfico 5 - Distribuição do valor adicionado em 2000 ........................................ 112

Gráfico 6 - Número médio de empregados de 1997 a 2000 .................................. 112

Gráfico 7 - Valor agregado por empregado de 1997 a 2000................................. 113

Gráfico 8 - Distribuição da amostra por ramos de atividade ................................ 117

Gráfico 9 - Valor adicionado pelas empresas da amostra em 1996 ....................... 118

Gráfico 10 - Distribuição do valor adicionado em 1996 - Comércio ..................... 118

Gráfico 11 - Distribuição do valor adicionado em 1996 - Indústria.......................119

Gráfico 12 - Distribuição do valor adicionado em 1996 - Serviços ....................... 119

Gráfico 13 - Valor adicionado pelas empresas da amostra em 1997 ...................... 120

Gráfico 14 - Distribuição do valor adicionado em 1997 - Comércio ..................... 120

Gráfico 15 - Distribuição do valor adicionado em 1997 - Indústria........................ 121

Gráfico 16 - Distribuição do valor adicionado em 1997 - Serviços ........................ 121

Gráfico 17 - Valor adicionado pelas empresas da amostra em 1998 ...................... 122

Gráfico 18 - Distribuição do valor adicionado em 1998 - Comércio ..................... 122

Gráfico 19 - Distribuição do valor adicionado em 1998 - Indústria ....................... 123

Gráfico 20 - Distribuição do valor adicionado em 1998 - Serviços ....................... 123

Gráfico 21 - Valor adicionado pelas empresas da amostra em 1999 ..................... 124

Gráfico 22 - Distribuição do valor adicionado em 1999 - Comércio ...................... 124

Gráfico 23 - Distribuição do valor adicionado em 1999 - Indústria ...................... 125

Gráfico 24 - Distribuição do valor adicionado em 1999 - Serviços ....................... 125

Gráfico 25 - Valor adicionado pelas empresas da amostra em 2000 ...................... 126

Gráfico 26 - Distribuição do valor adicionado em 2000 - Comércio ..................... 126

Gráfico 27 - Distribuição do valor adicionado em 2000 - Indústria ...................... 127

Gráfico 28 - Distribuição do valor adicionado em 2000 - Serviços ...................... 127

Gráfico 29 - Média de empregados por ramos de atividade - 1997 a 2000 ........... 128

Gráfico 30 - Valor adicionado por empregado de 1997 a 2000 - Por ramos ......... 128

Gráfico 31 - Número de empresas por setor ...................................................... 132 
Gráfico 32 - Maiores geradores de valor adicionado em 1996 133

Gráfico 33 - Maiores e menores distribuidores a empregados em 1996 ................ 134

Gráfico 34 - Maiores geradores de valor adicionado em 1997 ............................ 135

Gráfico 35 - Maiores e menores distribuidores a empregados em 1997 ................. 135

Gráfico 36 - Maiores geradores de valor adicionado em 1998 ............................. 136

Gráfico 37 - Maiores e menores distribuidores a empregados em 1998 .................136

Gráfico 38 - Maiores geradores de valor adicionado em 1999 ............................ 137

Gráfico 39 - Maiores e menores distribuidores a empregados em 1999 ................ 137

Gráfico 40 - Maiores geradores de valor adicionado em 2000 ............................. 138

Gráfico 41 - Maiores e menores distribuidores a empregados em 2000 ................ 138

Gráfico 42 - Maiores e menores distribuidores ao governo em 1996 ..................... 139

Gráfico 43 - Maiores e menores distribuidores ao governo em 1997 .................... 140

Gráfico 44 - Maiores e menores distribuidores ao governo em 1998 .................... 140

Gráfico 45 - Maiores e menores distribuidores ao governo em 1999 .................... 141

Gráfico 46 - Maiores e menores distribuidores ao governo em 2000 .................... 141

Gráfico 47- Média de empregados dos maiores empregadores de 1997 a 2000..... 155

Gráfico 48- Setores com maior e menor distribuição de VA por empregado......... 155

Gráfico 49 - Empresas geradoras de maior valor adicionado em 1997 ................... 163

Gráfico 50 - Empresas distribuidoras de maior valor adicionado por empregado em

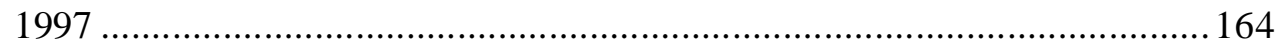

Gráfico 51 - Empresas geradoras de maior valor adicionado em 1998 .................. 164

Gráfico 52 - Empresas distribuidoras de maior valor adicionado por empregado em 1998 165

Gráfico 53 - Empresas geradoras de maior valor adicionado em 1999................... 165

Gráfico 54 - Empresas distribuidoras de maior valor adicionado por empregado em 1999 166

Gráfico 55 - Empresas geradoras de maior valor adicionado em 2000. 166

Gráfico 56 - Empresas distribuidoras de maior valor adicionado por empregado em 2000 167

Gráfico 57 - Coeficientes de correlação dos diversos setores. 172 


\section{LISTA DE TABELAS}

Tabela 1 - Evolução Temporal dos Indicadores de Desigualdade da Renda.............69

Tabela 2 - Evolução Temporal da Desigualdade da Renda.................................... 70

Tabela 3- Distribuição do rendimento, por Regiões e Unidades da Federação, dos $50 \%$ mais pobres e dos $1 \%$ mais ricos, em relação ao rendimento total ........... 71

Tabela 4 - Renda média familiar per capita, em reais e em salários mínimos, por Grandes Regiões e Unidades da Federação - 1992/1999................................ 73

Tabela 5 - Desigualdade da renda ao redor do mundo ........................................ 75

Tabela 6 - Distribuição da Renda ou do Consumo ................................................ 76

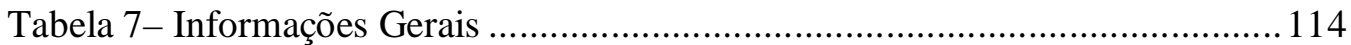

Tabela 8 - Número médio de empregados e percentual de 1997 a 2000 ................ 127

Tabela 9 - Informações gerais - por ramos de atividade ..................................... 130

Tabela 10 - Menores geradores de valor adicionado de 1996 a 2000 .................... 139

Tabela 11- Informações gerais por setores: Alimentos ….................................. 142

Tabela 12 - Informações gerais por setores: Atacado e comércio exterior ............. 142

Tabela 13- Informações gerais por setores: Automotivo.................................... 143

Tabela 14- Informações gerais por setores: Bebidas ........................................... 143

Tabela 15- Informações gerais por setores: Comércio varejista .......................... 144

Tabela 16- Informações gerais por setores: Comunicações................................... 144

Tabela 17 - Informações gerais por setores: Confecções e têxteis ......................... 145

Tabela 18- Informações gerais por setores: Construção ....................................... 145

Tabela 19- Informações gerais por setores: Diversos........................................... 146

Tabela 20- Informações gerais por setores: Eletroeletrônicos ............................... 146

Tabela 21- Informações gerais por setores: Farmacêutico................................... 147

Tabela 22- Informações gerais por setores: Fumo ........................................... 147 
Tabela 23- Informações gerais por setores: Higiene, limpeza e cosméticos 148

Tabela 24- Informações gerais por setores: Material de construção 148

Tabela 25- Informações gerais por setores: Mecânica 149

Tabela 26- Informações gerais por setores: Mineração 149

Tabela 27- Informações gerais por setores: Papel e celulose 150

Tabela 28- Informações gerais por setores: Plásticos e borrachas 150

Tabela 29- Informações gerais por setores: Química e petroquímica 151

Tabela 30- Informações gerais por setores: Serviço de transporte 151

Tabela 31- Informações gerais por setores: Serviços diversos 152

Tabela 32- Informações gerais por setores: Serviços públicos 152

Tabela 33- Informações gerais por setores: Siderurgia e metalurgia 153

Tabela 34- Informações gerais por setores: Tecnologia e computação 153

Tabela 35- Informações gerais por setores: Telecomunicações 154

Tabela 36 - Número médio de empregados e percentual dos setores responsáveis por mais de $50 \%$ das vagas no período. 154

Tabela 37 - Variações na evolução da riqueza e do valor adicionado por empregado por ramos de atividades 169

Tabela 38 - Variações na evolução da riqueza e do valor adicionado por empregado por setores 170 


\section{INTRODUÇÃO}

Pode-se afirmar que a contabilidade possui 3 grandes desafios: a identificação, a mensuração e a comunicação dos atos e fatos ocorridos em uma entidade.

O desafio em se comunicar, até então, vem sendo resolvido por meio da elaboração e divulgação das demonstrações contábeis ditas tradicionais, como: Balanço Patrimonial (BP), Demonstração do Resultado do Exercício (DRE), Demonstração das Origens e Aplicações de Recursos (DOAR), Demonstração das Mutações do Patrimônio Líquido (DMPL) e Notas Explicativas.

É por meio dessas demonstrações que as necessidades da maioria dos usuários da contabilidade, bem ou mal, vêm sendo atendidas, sejam eles sócios ou acionistas, fornecedores e financiadores, governo, administradores e empregados.

Estes últimos, entretanto, nunca obtiveram, por meio das demonstrações contábeis citadas, informações sobre suas próprias condições de trabalho, como higiene, segurança e salubridade, e sobre o peso de sua remuneração e respectivos encargos sociais, dentro do universo de agentes econômicos que colaboram para que a empresa atinja seu objetivo de gerar riqueza.

Também, a comunidade onde a entidade está inserida, e a sociedade de uma forma geral, jamais puderam contar com informações que as ajudassem a avaliar as vantagens e desvantagens em acolher essas entidades.

Nesse sentido, e principalmente com o surgimento de movimentos sociais iniciados na França, Alemanha e Inglaterra na década de 60, as exigências da sociedade em 
relação à cobrança de responsabilidade social por parte das empresas se tornaram mais intensas.

Estas exigências culminaram com a adoção, pela França no ano de 1977, do chamado Balanço Social, de forma obrigatória para as empresas com 300 empregados ou mais.

O Balanço Social é o instrumental que a contabilidade coloca à disposição da sociedade para demonstrar suas relações com a empresa.

Dentre as vertentes do Balanço Social, destaca-se a Demonstração do Valor Adicionado (DVA), que produz informações referentes à riqueza gerada pela empresa e a forma como foi feita sua distribuição aos agentes econômicos que ajudaram a produzi-la: os empregados, o governo, o proprietário, sócios e acionistas e a própria entidade, que retém os lucros.

Enquanto em alguns países do mundo não é sequer permitido que uma empresa se estabeleça em seu solo sem que apresente a DVA, no Brasil ela é pouco conhecida e divulgada, possivelmente por não tratar-se, ainda, de uma demonstração obrigatória. Dessa forma, um dos principais beneficiários de suas informações - os empregados por não contarem com nenhum tipo de informação semelhante, muitas vezes não a conhecem.

O caminho para a elaboração e, principalmente, divulgação da DVA, é longo. Muito se tem feito em prol disso, inclusive com a apresentação do Projeto de Lei $n^{\circ}$. 3.741/2000 pelo Poder Executivo, alterando a Lei 6.404/76 - a Lei das Sociedades por Ações - no que concerne às demonstrações contábeis obrigatórias. A DVA poderá passar a ser uma delas.

Entretanto, é necessário que se estabeleçam esforços, também, para a sua efetiva utilização, principalmente por aqueles que podem encontrar nela informações que, de outra forma, não estariam disponíveis. 


\section{CAPÍTULO 1 - O PROBLEMA DE PESQUISA}

\subsection{Identificação do Problema}

Dentre os males que se agravaram no final do século XX e início do século XXI, certamente a má distribuição de renda é dos mais relevantes. O problema é de âmbito mundial, mas em países ditos de terceiro mundo se apresenta mais acentuado, principalmente devido à queda no nível geral de empregos.

Na visão de Dupas ${ }^{1}$,

“...há algum tempo, a imagem do trabalhador repetindo o gesto de apertar parafusos - retratada por Charles Chaplin em Tempos Modernos - representava o pesadelo da modernidade. Hoje, esse posto de trabalho aparece como desejável e já quase um sonho distante de segurança e estabilidade."

Esta afirmativa ilustra claramente o paradoxo da situação vivida atualmente; o que já era uma conquista do trabalhador - o direito ao emprego - transformou-se em utopia. Continua, afirmando que

“...a percepção de que a dinâmica capitalista, que move a economia global neste final de século XX, pudesse estar agravando a exclusão social começou a se configurar como hipótese quando os índices de desemprego e marginalidade cresceram significativamente na França e Alemanha."

Especificamente no caso brasileiro, o que se observa é que, nas últimas décadas, grande parte do fardo representado pelos ajustes econômicos tem recaído sobre o mercado de trabalho, penalizando os trabalhadores com quedas de salário real, elevação do desemprego, deterioração das condições de trabalho e aumento da

\footnotetext{
${ }^{1}$ DUPAS, Gilberto. Economia global e exclusão social: pobreza, emprego, estado e o futuro do capitalismo. 2. ed. São Paulo: Paz e Terra, 2.000. p. 9, 19
} 
miséria. Além desses, um outro fato a ser considerado é a mudança setorial ocorrida no emprego, provocada pela queda na ocupação industrial e pela necessidade do setor em se tornar mais produtivo. $\mathrm{O}$ aumento da produtividade observado nos anos 90, oriundo, principalmente, da automação e reestruturação produtiva, provocou a migração de empregos. A economia sofreu fortes alterações: as empresas se transformaram e os empregos migraram, principalmente da área industrial para a comercial e de serviços. Em tempos de globalização, a forma encontrada para a elevação do produto passa pelo aumento da produtividade, e não mais pela expansão do emprego, como ocorria anteriormente.

Regra geral, o crescimento econômico de um país leva a um crescimento dos salários reais e, com ele, mais bens são colocados à disposição da sociedade. Com isso, ocorre uma elevação persistente na renda per capita da população, perceptível por meio de fatos tais como: diminuição das taxas de natalidade e mortalidade, aumento do sistema escolar e de saúde, maior acesso aos meios de transporte, de comunicação e culturais, dentre outros. Presume-se que a principal beneficiária do conjunto de transformações estruturais provocadas pelo desenvolvimento da economia seja a própria sociedade. No entanto, segundo Cacciamali ${ }^{2}$, no Brasil o que se observou foi que o crescimento econômico verificado a partir da década de 50: "áo contrário de outros países, mormente do leste asiático, que também cresceram de forma acelerada, a evolução dos indicadores sociais apresentou resultados pífios”. No seu entendimento, a má distribuição de renda no país tem como ponto de partida nosso passado colonial e escravocrata, onde a posse da terra caracterizou-se pela concentração na mão de poucos, pela violência na expropriação das terras ocupadas, e pelas dificuldades enfrentadas pelos novos ocupantes para legalizarem suas propriedades. Essa concentração se manteve ao longo dos séculos, chegando ao final do século XX nos mesmos moldes. Durante o período em que perdurou a inflação, esta se tornou um instrumento de transferência de renda a favor das camadas superiores da sociedade. O plano real, implementado a partir de 1994, apesar de

${ }^{2}$ CACCIAMALI, Maria Cristina. In: PINHO, Diva Benevides. VASCONCELOS, Marco A. Sandoval de (coord.). Manual de economia. 3. ed. São Paulo: Saraiva, 2.001. p. 437 
conseguir estabilizar o sistema de preços nacional e com isso ampliar o poder de compra dos estratos mais baixos da população, mantém restrições de ordem política e financeira que limitam a criação de políticas sociais que redistribuam os benefícios do desenvolvimento econômico à sociedade como um todo, principalmente nas áreas de educação, saúde e habitação.

Conforme observações da citada Cacciamali ${ }^{3}$ :

"As evidências empíricas sobre o Brasil mostram que o País vem ampliando os indices de desigualdades na distribuição da renda desde os anos 60 e apresenta um dos piores perfis de distribuição de renda do mundo (...). Ademais, indicadores sociais referentes à educação, saúde e habitação mostram-se inferiores àqueles de países com similar, ou até mesmo inferior, nível de renda per capita. Cada uma das décadas, desde 1.960, apresenta especificidades que ajudam a compor o quadro do aumento da concentração em cada um dos períodos."

Fato é que, de acordo com estudos realizados pela Organização das Nações Unidas ONU, publicados na Revista Veja ${ }^{4}$, o Brasil, considerado a décima maior economia do mundo, apresenta um Índice de Desenvolvimento Humano - IDH, próximo ao da Colômbia e do Suriname, sociedades com características de extrema pobreza. Esse índice é uma mostra de como vivem as pessoas, e é formado por indicadores sociais tais como taxa de mortalidade, de analfabetismo para pessoas com idade acima de 15 anos, taxa de expectativa de vida das pessoas que nascem, ou ainda qualidade de saneamento básico. Apesar de apresentar uma ligeira melhora com relação ao estudo anterior, o país continua no mesmo patamar, apresentando, quando se analisam regiões e cidades de forma isolada, municípios com taxa de desenvolvimento nos moldes africanos, com condições de vida subumanas. São José da Tapera, município do sertão alagoano do Brasil, é o vice-campeão mundial quando o assunto é a má qualidade de vida, perdendo o primeiro lugar apenas para Serra Leoa, Estado da África Ocidental.

${ }^{3}$ op. cit. p. 454

${ }^{4}$ LORES, Raul Juste. O que falta fazer. Revista Veja. São Paulo: ed. 1709. Abril, 2.001, 18jul.2001. p. 90-92 


\subsubsection{O papel da contabilidade}

A contabilidade, como veículo de informações, tem buscado se adaptar aos novos tempos, e atender à solicitação, ou diríamos imposição, de retratar as relações existentes entre as empresas e a sociedade, e principalmente de mostrar o retorno que essas empresas estão trazendo em benefício da melhoria da qualidade de vida da população.

Um dos instrumentos encontrados para isso é o Balanço Social que, num mesmo documento, evidencia tanto os aspectos econômicos quanto os aspectos sociais, inovando, com isso, o enfoque usado até então, onde a preocupação era basicamente com o capital. Para Tinoco ${ }^{5}$ :

'O Balanço Social tem por ambição descrever uma certa reali dade econômica e social de uma entidade, através do qual é suscetível de avaliação.

Em decorrência dele as relações entre o fator capital e o fator trabalho podem ser melhor regulados e harmonizados, na medida em que as forças sociais avancem e tomem posição, especialmente nos países de Terceiro Mundo, entre eles o Brasil, onde se observa a ocorrência de um capitalismo selvagem.

Nos países onde o capitalismo está mais desenvolvido várias empresas já vêm consagrando o balanço social como instrumento de gestão e de informação. Essas empresas divulgam normalmente informação econômica $e$ social a seus trabalhadores, pois sua estrutura não é posta em causa, sendo o lucro aceito como uma vocação normal da empresa, permitindo que a relação entre dirigentes $e$ assalariados torne-se consensual e não conflituosa.”.

Entretanto, diferentemente do que sentencia Tinoco, o que se observa é que os países em que o capitalismo está mais desenvolvido a selvageria econômica é a mesma, e o balanço social, quando utilizado, configura-se apenas como um instrumento de informações de recursos humanos e não de gestão, conforme poderá ser observado nos exemplos apresentados no item 2.1.3 O balanço social em outros países do mundo.

\footnotetext{
${ }^{5}$ TINOCO, João Eduardo Prudêncio. Balanço social - Uma abordagem sócio-econômica da contabilidade. Dissertação de mestrado - Faculdade de Economia e Administração da Universidade de São Paulo. São Paulo: FEA/USP, 1984.p. 45
} 
Dentro do objetivo de analisar a distribuição de renda dentro das empresas, importa apenas a parte desse conjunto de informações que evidencia o valor adicionado ou agregado, especificamente a Demonstração do Valor Adicionado, que mede o valor da riqueza gerada pelas empresas e a sua distribuição aos diversos setores, inclusive aos funcionários. A partir da mensuração da riqueza agregada pelas empresas por meio dessa demonstração, consegue-se, dentre outros, apurar o percentual de riqueza criado pela empresa em relação às suas vendas, o montante dos recursos gerados que foram repartidos ao governo por meio de impostos e contribuições, além da participação da empresa e também do setor na distribuição da renda no país.

No enfoque de distribuição de renda, é a referida demonstração que apresenta a contraprestação do fator de produção trabalho, representado pela remuneração paga aos empregados.

Um dos mais importantes elementos de distribuição de renda é a remuneração do trabalho. Ela engloba toda as despesas efetuadas pelos empregadores em contraprestação ao serviço realizado por esse fator de produção empregado em um período. Compreende pagamentos diretos aos assalariados, encargos sociais a cargo dos empregadores, além de outras vantagens como comissões, gratificações, participações nos lucros, planos de aposentadoria complementar, assistência médica, transporte, etc.

Devido à importância das informações geradas pela referida demonstração na busca por uma visão social do que antes era meramente econômico, o questionamento que norteará este trabalho será:

Existe relação entre a riqueza gerada pelas empresas, no Brasil, e a distribuição dessa riqueza aos seus funcionários, tomando-se como parâmetro as informações obtidas na Demonstração do Valor Adicionado? 


\subsection{Objetivos do trabalho}

\subsubsection{Objetivo Geral}

Considerando as informações prestadas na Demonstração do Valor Adicionado, avaliar a relação existente entre a variação da riqueza das empresas analisadas e a variação da remuneração dos empregados, verificando se a variação da riqueza tem efeito na remuneração paga aos funcionários, influenciando a distribuição de renda.

\subsubsection{Objetivos específicos}

Examinar a Demonstração Contábil do Valor Adicionado da amostra de empresas selecionadas.

Medir a participação dos funcionários na distribuição da riqueza gerada pelas empresas da amostra.

$>$ Analisar a variação existente na geração de riqueza das diversas empresas constantes da amostra e na distribuição dessa riqueza aos funcionários.

$>$ Aferir se as empresas geradoras de maior valor adicionado são as que mais distribuem riqueza por meio de remuneração aos seus funcionários.

\subsection{Hipóteses}

Segundo Martins ${ }^{6}$, 'Hipótese é um enunciado conjetural entre duas ou mais variáveis. Trata-se de suposições idealizadas na tentativa de antecipar respostas do problema de pesquisa."

Neste estudo as principais hipóteses que se apresentam para a orientação da pesquisa são:

${ }^{6}$ MARTINS, Gilberto de Andrade. Manual para elaboração de monografias e dissertações. 2. ed. São Paulo: Atlas, 2000. p. 33 
$\left.\mathrm{H}_{1^{-}}\right)$As empresas que geram maior riqueza, tomando como base as informações constantes na Demonstração do Valor Adicionado, são as que mais a distribuem aos seus funcionários.

$\mathrm{H}_{2}$-) Um incremento provocado na riqueza gerada pelas empresas resulta num aumento na distribuição dessa riqueza aos funcionários, considerando-se as informações da Demonstração do Valor Adicionado.

\subsection{Metodologia da Pesquisa}

Neste trabalho, pelas suas características, é utilizada uma abordagem EmpíricoAnalítica que, segundo Martins ${ }^{7}$ :

"são abordagens que apresentam em comum a utilização de técnicas de coleta, tratamento e análise de dados marcadamente quantitativos. Privilegiam estudos práticos. Suas propostas têm caráter técnico, restaurador e incrementalista. Têm forte preocupação causal entre variáveis. A validação da prova científica é buscada através de testes dos instrumentos, graus de significância e sistematização das definições operacionais."

Constitui-se de uma primeira parte onde é feita a fundamentação teórica e onde a técnica empregada é a pesquisa bibliográfica. Num segundo momento, são utilizados dados secundários para comprovação ou negação das hipóteses. Conforme Ferrari ${ }^{8}$, "As fontes secundárias são aquelas contribuições provenientes da documentação já analisada e publicada”. São também chamadas de documentos de segunda mão. Esses dados secundários foram levantados por meio do cadastro de empresas mantido pela Fundação Instituto de Pesquisas Contábeis, Atuariais e Financeiras FIPECAFI, órgão de apoio institucional ao Departamento de Contabilidade e Atuária da Faculdade de Economia, Administração e Contabilidade da Universidade de São Paulo - FEA/USP, que é o banco de dados usado na edição da 'Melhores $e$ Maiores" publicada anualmente pela Revista Exame. Compõe-se de 198 empresas, com informações dos anos de 1996 a 2000.

\footnotetext{
${ }^{7}$ op. cit. p. 26

${ }^{8}$ FERRARI, Alfonso Trujillo. Metodologia da pesquisa científica. São Paulo: McGraw-Hill do Brasil, 1982. p. 227.
} 


\subsection{Estrutura do trabalho}

Este trabalho está estruturado em 6 capítulos, além da introdução, da bibliografia e dos anexos e apêndices, em volume próprio, contendo as tabelas e quadros utilizados para as análises feitas, e os exemplos de balanço social de empresas em alguns países do mundo.

O Capítulo 1 - O Problema de pesquisa - procura identificar e caracterizar o problema a ser estudado. Inicia-se com o reconhecimento das dificuldades vividas atualmente, relacionadas à queda no nível geral de empregos, e estabelece-se o problema da distribuição de renda como estimulador do trabalho. Traçam-se os objetivos do estudo e define-se como propósito, a confirmação ou negação das hipóteses propostas e estabelece a metodologia da pesquisa.

No Capítulo 2 - Revisão da Bibliografia - são tratados os principais aspectos conceituais e referências bibliográficas. Procura-se abordar os itens específicos relacionados ao Balanço Social, Valor Adicionado e Renda, com enfoque na distribuição de renda e a legislação trabalhista no Brasil.

O Capítulo 3 - Aspectos práticos da DVA - apresenta a caracterização prática e a metodologia de elaboração dessa demonstração. Procura-se ressaltar, ainda, o tratamento dos elementos que a compõem.

O Capítulo 4 - Planejamento da Pesquisa e Coleta de Dados - descreve a metodologia e aplicação da pesquisa proposta, a caracterização da população e da amostra utilizadas e o tratamento a que foram submetidos os dados. São apresentadas informações sobre a Demonstração do Valor Adicionado de 198 empresas, nos anos de 1996 a 2000.

O Capítulo 5 - Análise dos Resultados - é destinado à divulgação e análise dos resultados da investigação proposta. 
Por fim, no Capítulo 6 - Conclusões - são apresentadas as deduções e recomendações próprias a este estudo. 


\title{
CAPÍTULO 2 - REVISÃO DA BIBLIOGRAFIA
}

\subsection{Balanço social}

Segundo Iudícibus ${ }^{9}$ :

\begin{abstract}
"o es tabelecimento dos objetivos da Contabilidade pode ser feito na base de duas abordagens distintas: ou consideramos que o objetivo da contabilidade é fornecer aos usuários, independentemente de sua natureza, um conjunto básico de informações que, presumivelmente, deveria atender igualmente bem a todos os tipos de usuários, ou a contabilidade deveria ser capaz e responsável pela apresentação de cadastros de informações totalmente diferenciados, para cada tipo de usuário."
\end{abstract}

Podemos considerar que a segunda abordagem é a desejável, inclusive defendida por Iudícibus, pois um cadastro de informações para atender às necessidades diversificadas dos diversos tipos de usuários tiraria da contabilidade o gesso representado pelas demonstrações tradicionais. Mas por enquanto podemos contar apenas com a primeira, ou seja, um conjunto básico de informações.

A contabilidade presta a seus principais usuários, aí incluídos sócios, acionistas, financiadores em geral, empregados, administradores e governo, informações econômico-financeiras, por meio das demonstrações tradicionais (como Balanço Patrimonial, Demonstração do Resultado do Exercício, etc.). O surgimento de movimentos sociais na França, Alemanha, Inglaterra, e ainda a aventura norteamericana na guerra do Vietnã, na década de 60, durante a administração Nixon, provocaram o repúdio da população e deram início a um movimento de boicote à aquisição dos produtos e ações daquelas empresas que se encontravam envolvidas com o conflito armado. A partir daí começou a ser requerida das empresas, uma

\footnotetext{
${ }^{9}$ IUDÍCIBUS, Sérgio. Teoria da contabilidade. 6. ed. São Paulo: Atlas, 2000. p. 19
} 
maior responsabilidade social, e a divulgação de informações sócio-econômicas juntamente com seus relatórios contábeis ${ }^{10}$.

Essa noção de responsabilidade social surgiu pela primeira vez nos EUA, na década de $30^{11}$, mas somente na década de 60 , suas empresas começaram a elaborar um modelo de demonstração social para a prestação de contas com o público, como forma de reagir às pressões sofridas da sociedade, na sua exigência por uma nova postura ética. Ao prestar contas de suas ações, visavam principalmente melhorar sua imagem perante consumidores e acionistas. Essa pressão partiu, principalmente, da influência exercida pelas igrejas, fundações, organizações caritativas, profissionais formadores de opinião, associações de ex-combatentes de guerra, dentre outros.

A partir desse momento, as empresas começaram a perceber que o fato de produzirem a preço justo e qualidade adequada não seria mais a única justificativa de sua existência perante a opinião pública. Conforme Délamo ${ }^{12}$, elas 'tem també $m$ que provar diante da sociedade que tal produção não se obteve à custa da pureza do seu ar, ou da dignidade dos seus habitantes, ou da fertilidade dos seus vales, ou da tranqüilidade das suas ruas e praças.”

E, ainda, que as variáveis sociais podem e devem fazer parte dos seus critérios de gestão, e a otimização do seu lucro não pode ser o único objetivo de suas atividades. Para Guerreiro ${ }^{13}$, a empresa tem objetivos sociais e econômicos e eles são perfeitamente conciliáveis. A empresa desempenharia duas funções integradas: a função econômica, que busca a maximização da taxa de retorno dos recursos

\footnotetext{
${ }^{10}$ DE LUCA, Márcia Martins Mendes. Demonstração do valor adicionado: do cálculo da riqueza criada pela empresa ao valor do PIB. São Paulo: Atlas, 1998. p. 23-24.

${ }^{11}$ TINOCO, João Eduardo Prudêncio. Balanço social e contabilidade de recursos humanos. In: SEMINÁRIO BALANÇO SOCIAL - UMA IDÉIA VIVA (3º. GRUPO). 1997, São Paulo. Apostila... São Paulo: JCA treinamentos e FIPECAFI - FEA/USP, 1997. p. 5.

${ }^{12}$ DÉLAMO, Alfonso Silva. O balanço social, utopia ou realidade na empresa Latino-Americana. In: GONÇALVES, Ernesto Lima (org.) Balanço social na América Latina.Tradução Maria Aparecida Ataliba de L.Gonçalves. Livraria Pioneira Editora. São Paulo: 1980. p. 2

${ }^{13}$ GUERREIRO, Reinaldo. Modelo conceitual de sistema de informação de gestão econômica: uma contribuição a teoria da comunicação da contabilidade. Tese de doutoramento-Faculdade de Economia e Contabilidade da Universidade de São Paulo. São Paulo: FEA/USP, 1989. p. 156
} 
financeiros investidos; e a função social, que busca promover o bem-estar dos grupos sociais que com ela interagem, mediante a distribuição da riqueza por ela gerada.

É preciso reconhecer, entretanto, que o sistema de informações contábeis disponível, representado pelas demonstrações tradicionais e voltado essencialmente para o desempenho econômico-financeiro, não possibilita a obtenção desses novos dados que interessam a tantos. Ele não mostra nem mensura o impacto do desempenho social da empresa e seu relacionamento com a comunidade onde está inserida, relegando a um plano secundário alguns usuários que contribuem, direta ou indiretamente, para a geração de riqueza das organizações. Dentre eles, os empregados e a própria comunidade, que cede os recursos para as organizações.

Para Gonçalves ${ }^{14}$ :

"A busca de um elemento básico na existência do homem moderno, representado pela qualidade de vida, estimulou em todos os centros acadêmicos e empresariais mais evoluídos o interesse por instrumentos de aferição do desempenho da empresa nesse campo de atividades. Nasceu aí a preocupação com elementos novos na vida da empresa e em seu âmbito administrativo traduzidos por denominações igualmente novas, como "Balanço social" e "indicadores sociais"."

Data dessa época, a década de 60, a realização das primeiras experiências das empresas relacionadas com a elaboração de relatórios que poderiam ser chamados de balanços sociais, nos diversos países do mundo, conforme será tratado no item 2.1.3 O balanço social em outros países do mundo.

\subsubsection{Aspectos conceituais}

Ao conjunto de informações que tem como principal objetivo mostrar em que grau se encontra o envolvimento das empresas em relação à sociedade e comunidade que a

\footnotetext{
${ }^{14}$ GONÇALVES, Ernesto Lima. Tentativa de um modelo básico de balanço social. In: GONÇALVES, Ernesto Lima (org.) Balanço social na América Latina.Tradução Maria Aparecida Ataliba de L.Gonçalves. Livraria Pioneira Editora. São Paulo: 1980. p. 49
} 
acolheram, dá-se o nome de balanço social. Esse aspecto é ressaltado por Ribeiro e Lisboa $^{15}$ :

'O Balanço Social é um instrumento de informação da empresa para a sociedade, por meio do qual a justificativa para sua existência deve ser explicitada. Em síntese, esta justificativa deve provar que o seu custo-benefício é positivo, porque agrega valor à economia e à sociedade, porque respeita os direitos humanos de seus colaboradores e, ainda, porque desenvolve todo o seu processo operacional sem agredir o meio ambiente."

Segundo o relatório do presidente do Conselho de Acionistas do Banco de Bilbao, escrito em junho de 1982 e citado por Kroetz ${ }^{16}$, o Balanço Social :

"e uma amostra da responsabilidade empresarial e a afirm ação concreta de que esta não se entende como algo absolutamente desligado da dimensão ética. Responsabilidade é o nome concreto da liberdade, correspondente àquele que sabe que atuou livremente. Mas, a responsabilidade de qualquer empresa tem sempre uma amplitude maior: a sociedade."

O caráter de embate entre capital e trabalho está evidenciado na afirmativa de Freire e Rebouças ${ }^{17}$ : 'O balanço social é o conjunto de informações com base técnico contábil, gerencial e econômica, capaz de proporcionar uma visão da relação capital-trabalho no que diz respeito a seus aspectos econômico-sociais.”

O balanço social se constitui, portanto, segundo justificativa do Projeto 39/97 ${ }^{18}$, apresentado por Aldaíza Sposati, num 'instrumento pelo qual as empresas demonstram através de indicadores, o cumprimento de sua função social”. Esses indicadores demonstram tanto a responsabilidade social das organizações e seus investimentos em seus empregados, quanto na comunidade em que está inserida.

\footnotetext{
${ }^{15}$ RIBEIRO, Maisa de Souza, LISBOA, Lázaro Plácido. Balanço social: instrumento de divulgação da interação da empresa com a sociedade. In: Encontro da ANPAD, 23ㅜ, 1999, Rio de Janeiro. Anais..., 1999. p. 1

${ }^{16}$ KROETZ, César Eduardo Stevens. Balanço social, teoria e prática. São Paulo: Atlas 2000. p. 66

${ }^{17}$ FREIRE, Fátima de Souza, REBOUÇAS, Tereza Raquel da Silva. Uma descrição sucinta do balanço social francês, português, belga e brasileiro. In: SILVA, César Augusto Tibúrcio, FREIRE, Fátima de Souza (organizadores). Balanço social: teoria e prática. São Paulo: Atlas, 2001. p. 104

${ }^{18}$ SÃO PAULO. Resolução 05/98 da Câmara Municipal da Cidade de São Paulo. Cria o dia e o selo da Empresa Cidadã às empresas que apresentarem qualidade em seu balanço social e dá outras providências.
} 
Segundo Souza ${ }^{19}$, esse instrumento de medição atende a todos. Oferece aos dirigentes os elementos necessários às tomadas de decisão, quando estas se referem aos programas e responsabilidades sociais desenvolvidos pelas empresas; aos empregados garante a possibilidade de verem suas expectativas chegando aos patrões de forma sistematizada e quantificada; aos investidores e fornecedores, leva o conhecimento sobre a maneira pela qual a empresa encara suas responsabilidades em relação ao seu quadro humano; aos consumidores oferece uma idéia do clima humano que reina na empresa, aproximando-a do seu mercado consumidor; ao Estado, o balanço social pode fornecer subsídios para elaboração de normas legais que regulamentem, da maneira mais adequada, a atividade das empresas, visando o bem estar da comunidade.

Ou ainda, conforme Sucupira ${ }^{20}$,

“...fazer e publicar o balanço social é mudar aquela visão tradicional em que a empresa deveria tratar apenas de produzir e obter lucro, sem se preocupar com a satisfação de sua força de trabalho e com o ambiente externo, para uma visão moderna em que os objetivos da empresa incorporam sua responsabilidade social."

Além de instrumento de medição, o balanço social se constitui num importante instrumento de planejamento e marketing, pois divulga a imagem da empresa em questões como, por exemplo, sua atitude ética no campo social. Mas ele não pode se resumir a isso, pois, segundo Taylor ${ }^{21}$,

'O balanço social não é, nem pode ser, um meio de dar publicidade ao fato de sermos muito bons no aspecto social. É um meio para verificar, realmente, como somos, objetiva e desapaixonadamente, por meio de uma avaliação asséptica dos resultados que vamos obtendo no campo social."

\footnotetext{
${ }^{19}$ SOUZA, Herbert de. Empresa pública e cidadã. Folha de São Paulo. São Paulo: 26 mar. 1997. p. 2

${ }^{20}$ SUCUPIRA, João A. Ética nas empresas e balanço social. In: SILVA, César Augusto Tibúrcio, FREIRE, Fátima de Souza (org.). Balanço social: teoria e prática. São Paulo: Atlas, 2001. p. 124

${ }^{21}$ TAYLOR, Robert. Balanço social: instrumental de avaliação de desempenho e correção do planejamento social na vida da empresa. In: GONÇALVES, Ernesto Lima (org.) Balanço social na América Latina.Tradução Maria Aparecida Ataliba de L.Gonçalves. Livraria Pioneira Editora. São Paulo: 1980. p. 32
} 
O Balanço Social possui pelo menos quatro ${ }^{22}$ vertentes, que são: a de Recursos Humanos, a Ambiental, a das Relações com a sociedade e a do Valor Adicionado. Conforme Ribeiro e Lisboa ${ }^{23}$, 'Estas vertentes podem ser tratadas isoladamente, como também em conjunto." Do balanço social, podem se obter indicadores tanto de ordem qualitativa quanto quantitativa, seja de caráter econômico, como a relação entre salários pagos ao trabalhador e as receitas brutas e a produtividade social da empresa, seja de caráter social, como nível de absenteísmo e evolução do emprego na empresa.

Para os objetivos deste estudo, a vertente que interessa é a do valor adicionado gerado pela empresa e a sua repartição e relação com um dos seus beneficiários, os empregados. Tinoco ${ }^{24}$ ressalta a importância do papel dos empregados na geração de riquezas, pois são aqueles que aportam seu trabalho às organizações e que recebem salários como contraprestação, favorecendo indiretamente a sociedade, por meio do sustento das pessoas dependentes da unidade familiar, e ao próprio Estado, que recebe os impostos sobre a renda.

\subsubsection{O primeiro balanço social no mundo - o francês}

O balanço social da França merece destaque, por se tratar do primeiro país no mundo a torná-lo obrigatório.

Sua elaboração é obrigatória desde o ano de 1977. A Lei 77.769 de 12 de junho de 1977, promulgada durante o governo de Valéry Giscard d'Estaing, instituiu a obrigatoriedade da elaboração e divulgação de um novo conjunto de informações sociais denominado de bilan social de l'entreprise - balanço social da empresa - a aquelas organizações com mais de 750 empregados a partir de 1979, e a partir de 1982 estendeu essa exigência às que contassem com mais de 300 empregados. Até

\footnotetext{
${ }^{22}$ Conforme o prof. Eliseu Martins In: BRAZ, Adriana. A importância do balanço social. Revista Mercado de Capitais. São Paulo: $\mathrm{n}^{\circ} .176,12-13$, jan/fev. 1999. p. 12

${ }^{23}$ op. cit. p. 14

${ }^{24}$ TINOCO, João Eduardo Prudêncio. Balanço social - Uma abordagem sócio-econômica da contabilidade. op. cit. p. 55
} 
então, apesar dos empregados serem considerados como usuários das informações contábeis, uma análise mais detalhada das Demonstrações Contábeis existentes revelava que, apesar destas contarem com uma quantidade bastante significativa de dados quantitativos e qualitativos, estes serviam principalmente aos acionistas, investidores, credores, clientes e fiscos, não trazendo, entretanto, essas peças, informações acerca de salários e outros benefícios.

Para Tinoco $^{25}$ "A lei francesa possui inegáveis méritos. Ela reconhece pela primeira vez de forma institucional a importância dos trabalhadores no seio da empresa, como usuário da informação contábil."

Entretanto, conforme pode-se observar no modelo de balanço social francês constante do Anexo A deste estudo, ele não contempla outras informações consideradas cruciais como, por exemplo, o valor adicionado bruto gerado pela empresa, concentrando-se nos aspectos de recursos humanos, o que não reduz, de forma alguma, seus méritos.

Evidencia, principalmente as relações dos empregados com a empresa. Além disso, diferentemente do que ocorre com as demonstrações contábeis tradicionais, que são elaboradas por um contador e, em alguns casos, conferidas por um auditor, o balanço social francês é geralmente feito por um empregado ligado à área de recursos humanos; não existindo nenhuma penalidade ou sanção aplicável em decorrência de irregularidades após sua preparação, o que segundo Freire e Rebouças ${ }^{26}$, gera incertezas quanto às suas informações e diminui sua credibilidade junto à comunidade.

Seu poder é apenas informativo, sem caráter de cunho decisório, o que o enfraquece para referenciar negociações. Entretanto, ele permite analisar a relação existente entre capital e trabalho, medindo a evolução da empresa nas questões relativas ao seu papel como célula social.

\footnotetext{
${ }^{25}$ op. cit. p. 37

${ }^{26}$ op. cit. p. $70-73$
} 
As linhas básicas de informação do balanço social, conforme a lei francesa, são: o emprego, as remunerações e os encargos acessórios, as condições de higiene e de segurança, as outras condições de trabalho, a formação profissional, as relações profissionais, e ainda as condições de vida dos empregados e de seus familiares, nas relações que dependam da empresa. Ele deve, ainda, ser submetido ao comitê da empresa, delegados sindicais e ao inspetor do trabalho, após ser aprovado em reunião de comitê, devendo ser afixado em local acessível a todos os funcionários da empresa. O balanço social do Anexo A, da France Telecom, apresenta as linhas de informação mencionadas, dentro de quatro itens. O primeiro, Empregados adaptabilidade e pragmatismo, trata dos empregados efetivos, do desenvolvimento das competências e da organização do tempo de trabalho; o segundo Remuneração individualização e descentralização, da remuneração individual e coletiva; o terceiro Relações Sociais - diálogo e proximidade, da representação das pessoas e atividades sociais; e o quarto Higiene, Segurança e Medicina Preventiva - prevenção e eficácia, das condições de higiene e segurança, dos acidentes de trabalho e no trajeto residência-trabalho-residência, das doenças profissionais e da medicina preventiva.

\subsubsection{O balanço social em outros países do mundo}

Na maioria dos países do mundo onde se encontra a figura do balanço social, sua elaboração e publicação é voluntária, mas em alguns outros, a exemplo da França, ele é obrigatório.

Conforme Tinoco ${ }^{27}$, a Holanda foi o primeiro país do mundo a ter publicados seus "social jarverslag" - relatórios sociais. Seu modelo se utiliza de medidas qualitativas para informar o impacto dos objetivos sociais da empresa, e quantitativas para programas sociais a serem implementados. As informações sobre trabalho e emprego ocupam posição de destaque, sem desprezarem as considerações de cunho econômico $^{28}$.

\footnotetext{
${ }^{27}$ op. cit. p. 96

${ }^{28}$ MENDES, Abadia Eleuza, et al. Balanço social: exercício de cidadania. Revista de Contabilidade do CRCSP . São Paulo:, ano II, n 6, 76-82, nov. 1998. p. 78
} 
Na Alemanha, a identificação do social à ecologia e às condições de trabalho faz parte de relatórios sociais. Os principais temas abordados nos relatórios alemães são os custos dos salários e encargos sociais, as despesas sociais voluntárias, a formação profissional, os esforços de informação interna, o número de acidentes, e ações para controle da poluição ambiental ${ }^{29}$.

$\mathrm{Na}$ Grã-Bretanha, várias empresas fornecem informações mais amplas aos seus usuários, dentre eles os empregados, não existindo um balanço para acionistas e outro para o pessoal. Estão reunidos, num mesmo documento, indicadores para julgamento tanto da situação econômica quanto dos dados sociais ${ }^{30}$.

Também na Espanha o balanço social é voluntário, sendo elaborado pelas empresas que julgam que devem ser transparentes. O Banco de Bilbao foi o pioneiro, publicando-o em $1978^{31}$.

No Chile, segundo Gonçalves ${ }^{32}$, a difusão da idéia de gestão social e de balanço social se iniciou na década de 70, a partir da iniciativa de um grupo de empresários. A empresa chilena pioneira na aplicação do balanço social foi a Associación Chilena de Seguridad (ACHS), em 1976. Conforme informações de Bárbara Délano ${ }^{33}$, diretora de relações institucionais da associação, seu balanço social já tem 26 anos e é feito rigorosamente a cada ano. Sua divulgação pública é feita na assembléia anual de sócios, mediante o auxílio da Memória Anual - o mesmo que relatório anual (onde é publicado junto com o balanço financeiro) e chega às 38.000 empresas filiadas (a associação é privada, sem fins lucrativos). Também é divulgado perante as mais altas autoridades governamentais do país, aos seus 3.700 trabalhadores, às cúpulas empresariais, às entidades acadêmicas e outras não-governamentais, sindicatos e comitês paritários. Sua metodologia é baseada no modelo francês, como pode ser observado no Anexo B, mas para sua adaptação à legislação, à mentalidade

\footnotetext{
${ }^{29}$ MENDES, Abadia Eluza, et al. op. cit. p. 77

${ }^{30}$ TINOCO, João Eduardo Prudêncio. op. cit. p. 98

${ }^{31}$ TINOCO, João Eduardo Prudêncio. op. cit. p. 99

32 op. cit. p. 55

${ }^{33}$ Informações fornecidas por meio de entrevista eletrônica, recebida por e-mail em 26/02/02.
} 
e à idiossincrasia do Chile, tem-lhe sido feitas algumas alterações, desde o início. Os indicadores sociais constantes do balanço social da ACHS, são priorizados pelos próprios trabalhadores, de forma voluntária e anônima. A cada um deles é atribuída uma pontuação que varia de 20 (equivalente à satisfação mínima) a 100 (equivalente à máxima satisfação). Os resultados são comparados com os do ano anterior, e calculados, então, o grau de avanço ou retrocesso nos índices dos indicadores sociais. O resultado é denominado de superávit ou déficit social, e é obtido pela diferença entre os ativos sociais - representados pelo crescimento no grau de satisfação dos trabalhadores - e os passivos sociais - representados pelo decréscimo no grau de satisfação. De acordo com a prioridade atribuída aos indicadores sociais pelos trabalhadores, os 4 níveis do balanço social da ACHS são, respectivamente: nível I segurança no emprego, satisfação no trabalho, sistema de remuneração, reconhecimento de méritos, e capacitação e desenvolvimento; nível II - imagem institucional, relações interpessoais, direito a opinião, benefícios de saúde, e sistemas de promoções e ascensões; nível III - qualidade da organização, grau de integração do pessoal, prevenção de acidentes de trabalho, condições físico-ambientais, e fundos de indenização; e nível IV - meios de comunicação interna, sistema de avaliação do desempenho, préstimos institucionais, e atividades extra trabalho. O resultado é medido em unidades padrão de satisfação (USS).

Enquanto nos EUA o enfoque dos "social audits" - relatórios econômico sociais - é o ambiente externo, como a satisfação dos consumidores/clientes, o controle da poluição, o acompanhamento da contribuição da empresa aos programas culturais, transportes coletivos e outros benefícios à coletividade, na Suécia a ênfase são as informações aos empregados ${ }^{34}$. Nos dois países a demonstração não é obrigatória.

Já na Bélgica e em Portugal o balanço social é obrigatório, conforme Freire e Rebouças $^{35}$. Na Bélgica ele é exigido de todas as empresas. Faz parte das demonstrações anuais e foi instituído em 1996 por meio de um decreto real, tendo,

\footnotetext{
${ }^{34}$ DE LUCA, Márcia Martins Mendes. Demonstração do valor adicionado: do cálculo da riqueza criada pela empresa ao valor do PIB. São Paulo: Atlas, 1998. p. 25

${ }^{35}$ op. cit. p. $79,80,95$
} 
para o governo, função decisória no que concerne à política de emprego. Segundo Gonzalez $^{36}$, várias empresas belgas informam que a publicação de balanços sociais tornou-se obrigatória, também, por exigência do mercado, visto que empresas que não o publicam não conseguem atuar vendendo seus produtos/serviços, pois a cada dia mais consumidores se recusam a consumir de empresas que não tenham balanço social ou que possuam, na sua cadeia produtiva, empresas que não o publicam. Um exemplo do balanço social belga se encontra no Anexo C. Esse modelo é dividido em 3 partes: a primeira demonstra o estado das pessoas efetivamente empregadas, as com trabalho temporário e as que se encontram a disposição da empresa - dados como, média de empregados, número de horas trabalhadas, gastos com pessoal, e número de empregados registrados no departamento pessoal - seja os que trabalham em tempo integral ou meio período; na segunda parte estão informações sobre o movimento do pessoal durante o período - saídas e entradas daqueles que trabalham por tempo integral e meio período; e na terceira parte consta a demonstração relativa à implementação de medidas que estimulam o emprego - relatando o número de pessoas empregadas envolvidas com uma ou mais medidas de estímulo ao emprego.

Finalmente, em Portugal, as empresas que tenham pelo menos cem empregados são obrigadas, desde 1985 pela Lei n. ${ }^{\circ}$ 141, a elaborarem o balanço social ao final do exercício social. Seu principal usuário é o Ministério do Emprego e da Seguridade Social, que envia cópias às associações, sindicatos dos empregados, e à Inspeção Geral do Trabalho. As empresas portuguesas devem, ainda, remeter o balanço social à comissão de trabalhadores e afixá-lo nos locais de trabalho ${ }^{37}$. Conforme modelo de balanço social português apresentado no Anexo D, pode-se observar que ele é composto de cinco capítulos, além de uma página inicial com a identificação da empresa e informações sobre o valor adicionado, custos com pessoal, dentre outras. No capítulo 1 constam informações sobre o emprego, como o número de pessoas em

\footnotetext{
${ }^{36}$ GONZALEZ, Roberto Souza. Balanço social - um disclosure necessário. In: SEMINÁRIO MERCADO DE CAPITAIS E BALANÇO SOCIAL. 2001, São Paulo. Apostila... São Paulo: AB AMEC, 2001. p. 8.

${ }^{37}$ FREIRE, Fátima de Souza, REBOUÇAS, Tereza Raquel da Silva. Uma descrição sucinta do balanço social francês, português, belga e brasileiro. In: SILVA, César Augusto Tibúrcio, FREIRE, Fátima de Souza (organizadores). Balanço social: teoria e prática. São Paulo: Atlas, 2001. p. 78-80
} 
serviço, de acordo com o tipo de contrato, as ausências verificadas, a estrutura etária e de habilitação do pessoal, além do nível de antigüidade, número de estrangeiros e deficientes. No capítulo 2 são especificados os custos com pessoal, seja com salário direto ou não. $\mathrm{O}$ capítulo 3 contém indicadores de higiene e segurança, dentre os quais, especificações sobre os acidentes de trabalhos, as ações de formação e sensibilização em matéria de segurança, e as atividades da medicina do trabalho. $\mathrm{O}$ capítulo 4 trata da formação profissional, com o número e o valor monetário das ações praticadas. E, finalmente, o capítulo 5, que traz os números da proteção social complementar, como os encargos suportados pela empresa, as prestações de ação social de apoio à infância e aos idosos, além de outras modalidades de apoio social (saúde, habitação, transporte, etc.).

Nos quatro modelos de balanço social pesquisados (francês, belga, chileno e português), constatou-se a presença de informações unicamente relacionadas com a área de Recursos Humanos, sem englobar as outras três vertentes já consideradas anteriormente: Valor Adicionado (exceto o modelo português, que contém a informação sobre o valor adicionado mas, não sua composição e cálculo), Ambiental, e Relações com a Sociedade.

Apenas no modelo chileno há a participação direta dos trabalhadores na sua elaboração pois, as informações são buscadas junto a eles, o que permite seu amplo envolvimento. Entretanto, de uma forma geral, todos apresentam informações que interessam particularmente à classe trabalhadora.

\subsubsection{O balanço social no Brasil}

No Brasil, as discussões sobre comportamento ético e responsabilidade social das empresas, tiveram início na década de 60, com a criação da Associação dos Dirigentes Cristãos de Empresas - ADCE. De acordo com Sucupira ${ }^{38}$, "Um dos princípios desta associação baseia-se na aceitação por seus membros de que a

\footnotetext{
${ }^{38}$ op. cit. p. 125
} 
empresa, além de produzir bens e serviços, possui a função social que se realiza em nome de trabalhadores e do bem-estar da comunidade."

Segundo informação de Flores ${ }^{39}$, apresentada por Torres, nesta mesma década de 60, uma empresa formada por Roberto Campos e outros técnicos ligados ao antigo Banco Nacional de Desenvolvimento - BNDE, de nome Consultec, realizava o balanço social para empresas multinacionais e nacionais, como base para avaliação interna e análise de risco, para implementação e expansão no país.

Há quem atribua à RAIS - Relação Anual de Informações Sociais, o papel de balanço social. Ela foi instituída pelo Decreto-Lei 76.900/1975, na primeira modalidade de relatório com destaque para aspectos sociais e de recursos humanos, e destinada a suprir as necessidades de controle, estatística e de informações das entidades governamentais da área social, além de atender ao pagamento do abono salarial aos trabalhadores que fazem jus a esse benefício, instituído pela Lei número 7.998/90. A RAIS, foi criada em plena era da ditadura militar, durante o governo Geisel, sendo obrigatória para todas as empresas atuantes no país a partir de 1977. Comparativamente ao balanço social francês, o relatório brasileiro é mais antigo, todavia, contém informações inferiores a ele, tanto qualitativa quanto quantitativamente, não exerce a função de balanço social, e principalmente não é divulgado para a sociedade como é ressaltado por Santos, Freire e Malo ${ }^{40}$ :

'Nas últimas três décadas, o Brasil vivenciou o que pode ser considerado conservadorismo político e social, combinado com abertura política e liberalismo econômico. A obrigatoriedade, instituída através de Decreto-Lei, em pleno regime militar, da apresentação pelas empresas sediadas no Brasil da RAIS, foi bastante insipiente, principalmente quando se compara com o modelo francês. De qualquer forma, deve-se salientar que, legalmente, foi uma das principais iniciativas que se tem conhecimento. Também deve ser destacado que os indicadores sociais produzidos através da utilização das informações advindas da RAIS são bastante

\footnotetext{
${ }^{39}$ FLORES, Jorge O. M. Na periferia da história. D' araújo, Maria Celina et al. Org.. Rio de Janeiro:FGV, 1999. p.130-133 In: TORRES, Ciro. Responsabilidade social das empresas (RSE) e balanço social no Brasil. In: SILVA, César Augusto Tibúrcio, FREIRE, Fátima de Souza (organizadores). Balanço social: teoria e prática. São Paulo: Atlas, 2001. p. 16

${ }^{40}$ SANTOS, Ariovaldo dos, FREIRE, Fátima S., MALO, François Bernard. O balanço social no Brasil: gênese, finalidade e implementação como complemento às demonstrações contábeis. In: Encontro da ANPAD, 23ㅜ, 1998, Foz do Iguaçu. Anais..., 1998. p. 6.
} 
limitados, e, pior, não são disponibilizados para os empregados das entidades ou suas associações de classe. A RAIS passará a ser uma verdadeira fonte de informações sociais, para os trabalhadores e a sociedade em geral, somente a partir do momento em que for elaborada de forma a permitir que todos possam acessá-la."

Cabe ressaltar que, apesar de há quase três décadas as empresas serem obrigadas a divulgar informações sobre seus funcionários, por meio da RAIS, estas se destinam ao Ministério do Trabalho e Emprego, exclusivamente para suprir as necessidades de controle e estatística das entidades governamentais na área social, principalmente no tocante ao cumprimento da legislação relativa ao Programa de Integração Social PIS, e Programa de Formação do Patrimônio do Servidor Público - PASEP, ao fornecimento de subsídios para controles relativos ao Fundo de Garantia por Tempo de Serviço - FGTS e Instituto Nacional de Seguridade Social - INSS, não sendo divulgadas à sociedade.

A RAIS contém informações dos estabelecimentos ou pessoas que, na condição de empregadores, mantiveram algum assalariado por qualquer período de tempo no decorrer do ano da declaração, seja por meio de contratos de trabalho regidos pela Consolidação das Leis Trabalhistas (CLT), temporários ou não, ou por meio do Regime Jurídico Único (RJU), no caso do funcionalismo público. O estabelecimento que não manteve empregados ou que permaneceu inativo também está obrigado à sua entrega. Seu conjunto de informações abrange, dentre outras: nome do empregado, código de inscrição no Programa de Integração Social (PIS) ou Programa de Formação do Patrimônio do Servidor Público (PASEP), raça, cor, tipos de salários contratuais, horas de trabalho semanais, pagamento do $13^{\circ}$. Salário, Classificação Brasileira de Ocupação (CBO), tipo de vínculo empregatício, grau de instrução dos empregados, contratações e desligamentos, e remunerações mensais.

Outro ponto a ser observado é que, tanto o balanço social francês, quanto a RAIS, se restringem a prestar apenas informações sobre recursos humanos, ou seja, não há diferenciação quanto a natureza das informações prestadas.

O que deve-se reforçar é que o balanço social, por sua vez, tem uma outra característica, a de divulgação voltada para o grande público em geral, possuindo, 
efetivamente, cunho social. Se a RAIS vier a se tornar de domínio público poderá passar a contar, também, com essa característica. Mas até o momento não existe nenhuma reivindicação nesse sentido, por nenhum setor da sociedade.

Ressalvada a obrigatoriedade da RAIS, o primeiro relatório de cunho social de uma empresa brasileira, publicado de forma totalmente voluntária, foi o da Nitrofértil, em 1984, destaca Torres ${ }^{41}$. Neste documento, que recebeu o nome de balanço social, a estatal localizada na Bahia tentava dar publicidade às ações sociais por ela realizadas, e também ao seu processo participativo desenvolvido durante o período. Também, em meados da década de 80 , foi publicado o relatório de atividades sociais do sistema Telebrás. Já no ano de 1992, o Banco do Estado de São Paulo (Banespa), produziu um relatório completo, denominado Balanço Social do Banespa, que foi publicado no início de 1993.

A partir de 1993, empresas de diversos setores passaram a divulgar, de forma mais recorrente, relatórios com um perfil mais social e humano, tornando os balanços sociais uma realidade para um número cada vez maior de empresas. Para Torres ${ }^{42}$ :

'Esse foi um importante período de consolidação da mudança de mentalidade de parcela expressiva do empresariado nacional, em que a visão de um capitalismo de cunho mais social, que busca maior negociação com amplas parcelas dos trabalhadores, está cada vez mais atenta aos problemas ambientais e sociais; e tem, de maneira crescente, levado em consideração a questão da ética e da responsabilidade social e ambiental na hora de tomar decisões."

Contudo, foi a partir do ano de 1997 que esse debate tomou lugar na mídia e começou a gerar resultados. Diversas organizações começaram a trabalhar ostensivamente com o tema, realizando seminários, palestras e cursos sobre ética, responsabilidade social e ambiental, e, principalmente, balanço social. O Departamento de Contabilidade e Atuária, da Faculdade de Economia, Administração e Contabilidade da Universidade de São Paulo, é um dos que têm estimulado estudos orientados para a área social, desde os anos 80.

${ }^{41}$ op. cit. p. 20

${ }^{42}$ op. cit. p. 21 
Em 26 de março de 1997, o jornal Folha de São Paulo publicou um artigo do sociólogo Herbert de Souza, o Betinho (1935-1997), intitulado "Empresa pública e cidadã", que serviu como um marco, dando origem à discussão, no Brasil, sobre a adoção do balanço social.

Motivadas pelos diversos eventos e artigos gerados desde então, as então Deputadas Federais Marta Suplicy (PT-SP), Sandra Starling (PT-MG) e Maria Conceição Tavares (PT-RJ), apresentaram à Câmara dos Deputados, o Projeto de Lei 3.116/97, datado de 14 de maio de 1997, que criava a obrigatoriedade de sua elaboração e publicação anual, pelas empresas privadas que tivessem cem empregados ou mais no ano anterior à sua elaboração e pelas empresas públicas, sociedades de economia mista, empresas permissionárias e concessionárias de serviços públicos, em todos os níveis da administração pública, independentemente do número de empregados. Esse Projeto de Lei foi arquivado em 01 de fevereiro de 1998.

No dia 16 de junho de 1997, o Instituto Brasileiro de Análises Sociais e Econômicas (IBASE), tendo à frente a figura carismática do mesmo Betinho, lançou uma campanha de mobilização pela divulgação do balanço social anual, que contou com o apoio de diversas organizações, como a Comissão de Valores Mobiliários (CVM), o Jornal Gazeta Mercantil, a Associação Brasileira de Companhias Abertas (ABRASCA), e a Associação Comercial do Rio de Janeiro, dentre outras, e lideranças empresariais.

De 1997 a 1998, alguns projetos sobre balanço social e responsabilidade social e ambiental das empresas foram apresentados em vários municípios brasileiros: Santo André (SP), Porto Alegre (RS), Santos (SP), João Pessoa (PB), Uberlândia (MG) e São Paulo (SP). Esse último, Projeto 39/97, foi aprovado em 23 de outubro de 1998, criando o "Dia e o Selo Empresa Cidadã do Município de São Paulo". Foi transformado na Resolução 05/98 e estabeleceu, em nível municipal, o dia 25 de outubro como o "Dia da Empresa Cidadã", e também a concessão de um 
selo/certificado para todas as empresas que apresentarem qualidade no seu balanço social anual ${ }^{43}$.

No ano de 1999, o deputado Paulo Rocha (PT-BA) apresentou um Projeto de Lei sobre o mesmo tema, o 0032/99, que atualmente se encontra em tramitação na Comissão de Economia, Indústria e Comércio da Câmara Federal, para apreciação e no aguardo de parecer. Esse Projeto de Lei é a reapresentação do Projeto de Lei $3116 / 97$.

O balanço social ainda é um instrumento pouco utilizado pelas empresas brasileiras, embora a quantidade de publicações cresça a cada ano. De acordo com dados do $\mathrm{IBASE}^{44}$, de 1997 para cá (2001), o número de empresas que publicam o balanço social saltou de 10 para 250 . Todas o divulgam de forma voluntária. Os motivos são vários. De acordo com Torres ${ }^{45}$, pode-se dizer que se trata de uma conjunção de interesse, vontade e necessidade do meio empresarial.

\subsubsection{O modelo do IBASE}

Não existe, ainda, consenso quanto à forma da apresentação do balanço social: se livre ou padronizado, se obrigatório ou voluntário, ou sobre quais informações, especificamente, ele deveria evidenciar. Algumas empresas, que vêm apresentando seus balanços sociais, o fazem no modelo do IBASE ou similar, com pequenas variações. Conforme dados coletados junto a esse instituto ${ }^{46}$, em 1997, ano de lançamento da campanha pela divulgação do balanço social pelas empresas, dos 10 balanços sociais apresentados no país, 4 foram feitos no seu modelo; em 1998, 8 dentre as 36 empresas divulgadoras; em 1999, o número saltou para 44 entre as 100,

\footnotetext{
${ }^{43}$ TORRES, Ciro. Responsabilidade social das empresas (RSE) e balanço social no Brasil. In: SILVA, César Augusto Tibúrcio, FREIRE, Fátima de Souza (organizadores). Balanço social: teoria e prática. São Paulo: Atlas, 2001. p. 28-29

${ }^{44}$ MANFREDINI, Camila. Mais empresas publicam o balanço social. Gazeta Mercantil. São Paulo: 23 mar. 2001, p. A10

45 op. cit. p. 22

${ }^{46}$ Informações fornecidas por Ciro Torres do Instituto Brasileiro de Análises Sociais e Econômicas - IBASE, por meio de entrevista eletrônica disponibilizada por e-mail em 01/02/02.
} 
atingindo 70 empresas com modelo IBASE, das cerca de 250 grandes empresas que publicaram seu balanço social no período de 2000 até julho de 2001.

A posição do Prof. Eliseu Martins, externada em $1998^{47}$, é de que "as empresas, $o$ mercado e a comunidade devem definir a evolução e o amadurecimento desta forma de comunicação sem imposições legais e sem engessar este balanço com um padrão que, não necessariamente, é o mais adequado para todas as empresas.”

A adesão espontânea das empresas também era defendida por Betinho ${ }^{48}$, que julgava ser esta a solução ideal e o argumento mais poderoso a seu favor, apesar de entender que a vantagem da regulamentação seria a legitimidade institucional.

Posição contrária é defendida por Sucupira ${ }^{49}$ :

"...se a forma de apresentação de informaçõ es for inteiramente livre, como tem sido a prática, torna-se difícil uma avaliação adequada da função social da empresa, já que ela tende a informar apenas o que lhe parece conveniente, geralmente, sem dimensionar valores de gastos. Dessa forma, o balanço social confunde-se com uma mera peça de marketing."

Objetivando a facilidade de comparação conseguida com a padronização, o IBASE, em parceria com técnicos, pesquisadores e diversos representantes de instituições públicas e privadas, concebeu e concluiu, no primeiro semestre de 1997, um modelo de balanço social que obteve o apoio da CVM. Tal modelo, com as modificações e adaptações ocorridas desde então se encontra na Figura 1. Segundo Torres ${ }^{50}$,

'Este modelo tem quatro particularidades que valem a pena se $r$ destacadas:

a) foi criado com base na iniciativa de uma ONG, que cobra transparência e efetividade nas ações sociais e ambientais das empresas;

b) separa as ações e os benefícios obrigatórios, dos realizados de forma voluntária pelas empresas;

c) é basicamente quantitativo; $e$

d) se for corretamente preenchido, pode permitir a comparação entre diferentes empresas e uma avaliação de uma mesma corporação, ao longo dos anos.”

${ }^{47}$ ELISEU quer balanço social sem imposições legais. São Paulo: SIA \& CIA, no ${ }^{\circ}$. 421, p. 3, 09 nov. 1998.

${ }^{48}$ SOUZA, Herbert de. Balanço social: voluntário ou obrigatório? Folha de São Paulo. São Paulo: 07 abr.1997

${ }^{49}$ op. cit. p. 127

50 op. cit. p. 26 
Figura 1 - Modelo de balanço social do IBASE e instruções de preenchimento

\begin{tabular}{|c|c|c|c|c|c|c|}
\hline 1) Base de Cálculo & 2001 & 1 Valor (Mil I & Reais) & & 0 Valor (Mil R & (eais) \\
\hline Receita Líquida (RL) & & & & & & \\
\hline Resultado Operacional (RO) & & & & & & \\
\hline Folha de Pagamento Bruta (FPB) & & & & & & \\
\hline 2) Indicadores Sociais Internos & $\begin{array}{c}\text { Valor } \\
\text { (Mil R\$) }\end{array}$ & $\begin{array}{c}\text { \%Sobre } \\
\text { FPB }\end{array}$ & \%Sobre RL & $\begin{array}{c}\text { Valor } \\
\text { (Mil R\$) }\end{array}$ & $\begin{array}{c}\text { \%Sobre } \\
\text { FPB }\end{array}$ & \%Sobre RL \\
\hline Alimentação & & & & & & \\
\hline Encargos sociais compulsórios & & & & & & \\
\hline Previdência privada & & & & & & \\
\hline Saúde & & & & & & \\
\hline Segurança e medicina no trabalho & & & & & & \\
\hline Educação & & & & & & \\
\hline Cultura & & & & & & \\
\hline Capacitação e desenvolvimento profissional & & & & & & \\
\hline Creches ou auxílio-creche & & & & & & \\
\hline Participação nos lucros ou resultados & & & & & & \\
\hline Outros & & & & & & \\
\hline Total - Indicadores Sociais Internos & & & & & & \\
\hline 3) Indicadores Sociais Externos & $\begin{array}{c}\text { Valor } \\
\text { (Mil R\$) }\end{array}$ & $\begin{array}{l}\text { \%Sobre } \\
\text { RO }\end{array}$ & \%Sobre RL & $\begin{array}{c}\text { Valor } \\
\text { (Mil R\$) }\end{array}$ & \%Sobre RO & \%Sobre RL \\
\hline Educação & & & & & & \\
\hline Cultura & & & & & & \\
\hline Saúde e saneamento & & & & & & \\
\hline Habitação & & & & & & \\
\hline Esporte & & & & & & \\
\hline Lazer e diversão & & & & & & \\
\hline Creches & & & & & & \\
\hline Alimentação & & & & & & \\
\hline Outros & & & & & & \\
\hline Total das Contribuições para a Sociedade & & & & & & \\
\hline Tributos (excluídos encargos sociais) & & & & & & \\
\hline Total - Indicadores Sociais Externos & & & & & & \\
\hline 4) Indicadores Ambientais & & & & & & \\
\hline Relacionados com a operação da empresa & & & & & & \\
\hline Em Programas e/ou projetos externos & & & & & & \\
\hline Total dos Investimentos em Meio Ambiente & & & & & & \\
\hline 5) Indicadores do Corpo Funcional & & & & & & \\
\hline $\mathrm{N}^{\circ}$ de empregados ao final do período & & & & & & \\
\hline $\mathrm{N}^{\circ}$ de admissões durante o período & & & & & & \\
\hline$N^{o}$ de empregados terceirizados & & & & & & \\
\hline $\mathrm{N}^{\circ}$ de empregados acima de 45 anos & & & & & & \\
\hline $\mathrm{N}^{\circ}$ de mulheres que trabalham na empresa & & & & & & \\
\hline$\%$ de cargos de chefia ocupados por mulheres & & & & & & \\
\hline $\mathrm{N}^{\circ}$ de negros que trabalham na empresa & & & & & & \\
\hline $\begin{array}{l}\% \text { de cargos de chefia ocupados por negros } \\
\mathrm{N}^{0} \text { de empregados portadores de deficiência }\end{array}$ & & & & & & \\
\hline $\mathrm{N}^{\circ}$ de empregados portadores de deficiência & & & & & & \\
\hline 6) Informações Relevantes quanto ao Exercíci & o da Cidadani: & a Empresaria & & & & \\
\hline $\begin{array}{l}\text { Relação entre a maior e a menor remuneração } \\
\text { na empresa }\end{array}$ & & & & & & \\
\hline Número total de acidentes de trabalho & & & & & & \\
\hline $\begin{array}{l}\text { Os projetos sociais e ambientais desenvolvidos } \\
\text { pela empresa foram definidos: }\end{array}$ & 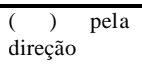 & $\begin{array}{l}\text { ( ) direção } \\
\text { e gerências }\end{array}$ & $\begin{array}{l}\text { ( ) todos os } \\
\text { empregados }\end{array}$ & 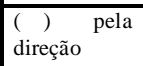 & $\begin{array}{l}\text { ( ) direção e } \\
\text { gerências }\end{array}$ & $\begin{array}{l}\text { ( ) todos os } \\
\text { empregados }\end{array}$ \\
\hline $\begin{array}{l}\text { Os padrões de segurança e salubridade no } \\
\text { ambiente de trabalho foram definidos: }\end{array}$ & $\begin{array}{l}(\stackrel{)}{ } \text { pela } \\
\text { direção }\end{array}$ & $\begin{array}{l}\text { ( ) direção } \\
\text { e gerências }\end{array}$ & $\begin{array}{l}\text { ( ) todos os } \\
\text { empregados }\end{array}$ & $\begin{array}{l}\left(\begin{array}{l}( \\
\text { direção }\end{array}\right. \\
\text { pela }\end{array}$ & $\begin{array}{l}\text { ( ) direção e } \\
\text { gerências }\end{array}$ & $\begin{array}{l}\text { ( ) todos os } \\
\text { empregados }\end{array}$ \\
\hline A previdência privada contempla: & ( ) direção & $\begin{array}{l}\text { ( ) direção } \\
\text { e gerências }\end{array}$ & $\begin{array}{l}\text { ( ) todos os } \\
\text { empregados }\end{array}$ & ( ) direção & $\begin{array}{l}\text { ( ) direção e } \\
\text { gerências }\end{array}$ & $\begin{array}{l}\text { ( ) todos os } \\
\text { empregados }\end{array}$ \\
\hline $\begin{array}{l}\text { A participação nos lucros ou resultados } \\
\text { contempla: }\end{array}$ & ( ) direção & $\begin{array}{l}\text { ( ) direção } \\
\text { e gerências }\end{array}$ & $\begin{array}{l}\text { ( ) todos os } \\
\text { empregados }\end{array}$ & ( ) direção & $\begin{array}{l}\text { ( ) direção e } \\
\text { gerências }\end{array}$ & $\begin{array}{l}\text { ( ) todos os } \\
\text { empregados }\end{array}$ \\
\hline $\begin{array}{l}\mathrm{Na} \text { seleção dos fornecedores, os mesmos } \\
\text { padrões éticos e de responsabilidade social e } \\
\text { ambiental adotados pela empresa: }\end{array}$ & $\begin{array}{l}\text { ( ) não são } \\
\text { considerados }\end{array}$ & 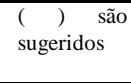 & \begin{tabular}{ll|}
$\left(\begin{array}{l}( \\
\text { exigidos }\end{array}\right.$ & são \\
\end{tabular} & $\begin{array}{l}\text { ( ) não são } \\
\text { considerados }\end{array}$ & $\begin{array}{l}(\quad) \text { são } \\
\text { sugeridos }\end{array}$ & $\begin{array}{ll}\left(\begin{array}{l}\text { ( }) \\
\text { exigidos }\end{array}\right. & \text { são } \\
\end{array}$ \\
\hline $\begin{array}{l}\text { Quanto à participação dos empregados em } \\
\text { programas de trabalho voluntário, a empresa: }\end{array}$ & $\begin{array}{l}\text { ( ) não se } \\
\text { envolve }\end{array}$ & ( ) apóia & $\begin{array}{l}\text { ( ) organiza } \\
\text { e incentiva }\end{array}$ & $\begin{array}{l}\text { ( ) não se } \\
\text { envolve }\end{array}$ & ( ) apóia & $\begin{array}{l}\text { ( ) organiza e } \\
\text { incentiva }\end{array}$ \\
\hline 7) Outras Informações & & & & & & \\
\hline & & & & & & \\
\hline & & & & & & \\
\hline & & & & & & \\
\hline
\end{tabular}




\begin{tabular}{|c|c|}
\hline \multicolumn{2}{|l|}{ Instruções para o preenchimento } \\
\hline Realização & $\begin{array}{l}\text { Este Balanço Social (BS) deve apresentar os projetos e as ações sociais e ambientais } \\
\text { efetivamente realizados pela empresa. } \\
\text { Sugestão: este BS deve ser o resultado de amplo processo participativo que envolva a } \\
\text { comunidade interna e externa. }\end{array}$ \\
\hline Publicação & $\begin{array}{l}\text { Este BS deve ser apresentado como complemento em outros tipos de demonstrações } \\
\text { financeiras e socioambientais; publicado isoladamente em jornais e revistas; amplamente } \\
\text { divulgado entre funcionários, clientes, fornecedores e a sociedade. Pode ser acompanhado } \\
\text { de outros itens e de informações qualitativas (textos e fotos) que a empresa julgue } \\
\text { necessários. }\end{array}$ \\
\hline Selo "Balanço Social Ibase/Betinho" & $\begin{array}{l}\text { A empresa que realizar e publicar o seu balanço social, utilizando este modelo mínimo } \\
\text { sugerido pelo Ibase, recebe o direito de utilizar o Selo Balanço Social Ibase/Betinho nos } \\
\text { seus documentos, relatórios, papelaria, produtos, embalagens, site e etc. Mais informações: } \\
\text { www.balancosocial.org.br } \\
\text { Restrições: o Selo Ibase/Betinho NÃO será fornecido às empresas de cigarro/fumo, } \\
\text { armas de fogo/muniçôes, bebidas alcoólicas ou que estejam comprovadamente } \\
\text { envolvidas com exploração de trabalho infantil. }\end{array}$ \\
\hline 1) Base de Cálculo & Itens Incluídos \\
\hline & $\begin{array}{l}\text { Receita bruta excluída dos impostos, contribuições, devoluções, abatimentos e } \\
\text { descontos comerciais }\end{array}$ \\
\hline Resultado Operacional & . Lucro ou prejuízo apresentado pela empresa no período \\
\hline Folha de Pagamento Bruta & Valor total da folha de pagamento \\
\hline \multicolumn{2}{|l|}{ 2) Indicadores Sociais Internos } \\
\hline & $\begin{array}{l}\text { Gastos com restaurante, vale-refeição, lanches, cestas básicas e outros relacionados à } \\
\text { alimentação dos empregados }\end{array}$ \\
\hline Previdência privada & $\begin{array}{l}\text { Planos especiais de aposentadoria, fundações previdenciárias, complementações de } \\
\text { benefícios aos aposentados e seus dependentes }\end{array}$ \\
\hline Saúde & $\begin{array}{l}\text { Plano de saúde, assistência médica, programas de medicina preventiva, programas de } \\
\text { qualidade de vida e outros gastos com saúde, inclusive dos aposentados }\end{array}$ \\
\hline Educação & $\begin{array}{l}\text { Gastos com ensino regular em todos os níveis, reembolso de educação, bolsas, } \\
\text { assinaturas de revistas, gastos com biblioteca (excluído pessoal) e outros gastos com } \\
\text { educação }\end{array}$ \\
\hline Cultura & $\begin{array}{l}\text { Gastos com eventos e manifestações artísticas e culturais (música, teatro, cinema, } \\
\text { literatura e outras artes) }\end{array}$ \\
\hline Capacitação e desenvolvimento profissional & $\begin{array}{l}\text { Recursos investidos em treinamentos, cursos, estágios (excluído os salários) e gastos } \\
\text { voltados especificamente para capacitação relacionada com a atividade desenvolvida pelos } \\
\text { empregados }\end{array}$ \\
\hline Creches ou auxílio-creche & Creche no local ou auxílio-creche aos empregados \\
\hline Participação nos lucros ou resultados & . Participações que não caracterizem complemento de salários \\
\hline Outros benefícios & $\begin{array}{l}\text { Seguros (parcela paga pela empresa), empréstimo (só o custo), gastos com atividades } \\
\text { recreativas, transportes, moradia e outros benefícios oferecidos os empregados podem ser } \\
\text { aqui enumerados }\end{array}$ \\
\hline \multicolumn{2}{|l|}{ 3) Indicadores Sociais Externos } \\
\hline Tributos (excluídos encargos sociais) & $\begin{array}{l}\text { Somatório dos investimentos na comunidade que aparecem discriminados. Não incluir } \\
\text { os gastos declarados nos Indicadores Laboriais. Os itens na tabela aparecem como } \\
\text { indicação de setores importantes onde a empresa deve investir, porém podem aparecer aqui } \\
\text { somente os investimentos e contribuições que a empresa realiza regularmente (ação } \\
\text { focalizada em educação, por exemplo) } \\
\text {. Impostos, contribuições e taxas federais, estaduais e municipais }\end{array}$ \\
\hline \multicolumn{2}{|l|}{ 4) Indicadores Ambientais } \\
\hline Relacionados com a operação da empresa & $\begin{array}{l}\text { Investimentos, monitoramento da qualidade dos resíduos/efluentes, despoluição, } \\
\text { gastos com a introdução de métodos não-poluentes, auditorias ambientais, programas de } \\
\text { educaçãao ambiental para os funcionários e outros gastos com o objetivo de incrementar a } \\
\text { qualidade ambiental na operação da empresa } \\
\text {. Despoluição, conservação de recursos ambientais, campanhas ambientais, educação } \\
\text { ambiental para a comunidade externa e para sociedade }\end{array}$ \\
\hline \multicolumn{2}{|l|}{ 5) Indicadores do Corpo Funcional } \\
\hline $\mathrm{N}^{\circ}$ de negros que trabalha na empresa & $\begin{array}{l}\text { Considerar como trabalhadores negros o somatório de indivíduos classificados como } \\
\text { pretos e pardos (conforme a RAIS) }\end{array}$ \\
\hline \multicolumn{2}{|l|}{ 6) Informações Relevantes } \\
\hline Relação entre a maior e a menor remuneração & Resultado da divisão da maior remuneração pela menor \\
\hline Número total de acidentes de trabalho & . Todos os acidentes de trabalho registrados durante o ano \\
\hline \multicolumn{2}{|l|}{ 7) Outras Informações } \\
\hline & $\begin{array}{l}\text { Este espaço está disponível para que a empresa agregue outras informações } \\
\text { importantes quanto ao exercício da responsabilidade social e da cidadania empresarial }\end{array}$ \\
\hline
\end{tabular}

Fonte: INSTITUTO BRASILEIRO DE ANÁLISES SOCIAIS E ECONÔMICAS - IBASE. Balanço social anual 2001. Disponível em http://www.balancosocial.org.br/downbs/bsMODELO2001.doc Acesso em 21/03/02. 
O modelo de balanço social, sugerido pelo IBASE, contém informações divididas em sete grandes grupos: no grupo 1, denominado base de cálculo, são requeridos dados sobre geração de receitas, resultado operacional e folha de pagamento bruta; o grupo 2 é o dos indicadores sociais internos, mostrando, dentre outros, os gastos com alimentação, educação, capacitação e saúde, relacionados aos empregados; no grupo 3 apresentam-se os indicadores sociais externos, ou seja, os gastos da empresa na comunidade e com os tributos; os indicadores ambientais fazem parte do grupo 4 e englobam os gastos com despoluição, educação ambiental e outros, seja com os empregados, comunidade externa ou sociedade; o grupo 5 é o dos indicadores do corpo funcional, como número de admissões, mulheres, negros e portadores de deficiência física; as informações relevantes quanto ao exercício da cidadania empresarial, como número de acidentes do trabalho e responsabilidade dos padrões de segurança e insalubridade existentes, estão definidos no grupo 6; e finalmente no grupo 7, a empresa declarará outras informações que julgar necessárias.

Quanto ao modelo reproduzido, cabe ressaltar que ele não evidencia qualquer tipo de informação relacionada ao valor adicionado, ou seja, não mostra como foi criada riqueza pela empresa e como esta foi distribuída aos agentes participantes do processo produtivo.

É questionável, também, o fato de ser denominado balanço social e apresentar o inconveniente de não se tratar de um balanço, no sentido contábil da palavra. Não demonstrar um Ativo, compreendendo as aplicações dos recursos, e nem um Passivo, abrangendo as exigibilidades e obrigações, a exemplo do balanço patrimonial tradicional. Restringe-se a evidenciar os gastos e as contribuições da empresa com a sociedade e a comunidade em que ela está inserida, sem considerar o quanto esta cedeu em prol disso, ou seja, trata-se de um relatório que demonstra o conjunto de ações consideradas ecologicamente corretas e socialmente responsáveis, o que não tira, de forma alguma, seu mérito. A utilização de outro termo para designá-lo, relatório contábil ou informação social, é mais precisa, mas, será que teria o mesmo impacto e repercussão? O modelo tem como vantagem a simplicidade, que permite o envolvimento de um número maior de empresas e 
diminui a resistência ao levantamento das informações para a produção do documento. Entretanto, não apresenta informações sobre valor adicionado que, conforme ressaltou-se anteriormente, é uma das 4 vertentes formadoras do balanço social.

\subsection{Valor adicionado}

No desempenho das atividades produtivas, acontece o consumo de recursos e, em contrapartida, a geração de produtos. Haverá geração de riqueza (ou agregação de valor) sempre que o valor econômico do produto que foi gerado for superior ao valor dos recursos consumidos para sua geração ${ }^{51}$. Quando o valor for inferior, não se criou riqueza.

O quanto as atividades produtivas agregaram de valor aos insumos adquiridos, é denominado de valor adicionado.

O conceito de valor adicionado, apesar de ser originalmente econômico, vem, mais recentemente, sendo utilizado também na contabilidade.

\subsubsection{Conceito econômico}

Dentro da visão econômica, De Luca $^{52}$, baseada em Rossetti, afirma que o valor adicionado (ou valor agregado) é utilizado para a avaliação do chamado Produto Nacional. O Produto Nacional, para o referido autor ${ }^{53}$, é 'a medida, em unidades monetárias, do fluxo total de bens e serviços finais produzidos pelo sistema econômico em determinado período.” (grifo da autora)

\footnotetext{
${ }^{51}$ SANTOS, Ariovaldo dos, LUSTOSA, Paulo Roberto B. Proposta de um modelo de DVA - Demonstração do Valor Adicionado - adequado ao novo desenho institucional e mercantil do setor elétrico brasileiro. São Paulo: Fundação Instituto de Pesquisa Econômica - FIPE, 1998. p. 3

52 op. cit. p. 28

${ }^{53}$ ROSSETTI, José Paschoal. Introdução à economia. 6. ed. São Paulo: Atlas, 1995. p. 518.
} 
Uma das preocupações dos estatísticos na apuração do Produto Nacional é evitar que um produto ou serviço seja incluído mais de uma vez no mesmo cálculo, já que alguns produtos são utilizados como insumos na produção de outros, ou seja, a chamada contagem múltipla ou dupla contagem. Sob este aspecto, Dornbusch e Fischer $^{54}$ ressaltam que não se pode incluir no cálculo do Produto Nacional, por exemplo, o preço total de um automóvel, e depois incluir, também, o valor dos pneus, peças, aço, ou quaisquer outros componentes que o fabricante adquiriu para a montagem do mesmo.

Para evitar tal problema, são computados no cálculo do Produto Nacional apenas os produtos e serviços de consumo final, conforme ficou ressaltado no conceito de Rosseti citado anteriormente, e não os consumos intermediários realizados durante as diversas etapas do processo produtivo. Entende-se por consumos intermediários os bens e serviços utilizados na produção de outros bens e serviços, e que, ou se incorporam ao produto durante o processo produtivo (a matéria-prima, por exemplo), ou desaparecem com ele (energia elétrica, por exemplo); e, por produtos e serviços de consumo final, aqueles que são produzidos e/ou comprados, mas não são revendidos ou consumidos durante o período corrente, ou, segundo Yoshioca ${ }^{55}$, aqueles que sirvam à satisfação das necessidades humanas.

A medição do valor do Produto Nacional, sem duplicações, é obtida, também, considerando-se em cada uma das etapas produtivas aquilo que foi acrescido ao valor dos bens de consumo intermediário utilizados, ou seja, somente a riqueza realmente criada pela entidade econômica, que é o valor adicionado. E é dessa forma que o problema da dupla contagem no cálculo do Produto Nacional é contornado, pelos estatísticos, utilizando-se do conceito de valor adicionado.

\footnotetext{
${ }^{54}$ DORNBUSCH, Rudiger, FISHER, Stanley. Macroeconomia. São Paulo: McGraw-Hill, 1982. p. 42. In DE LUCA, Márcia Martins Mendes. Demonstração do valor adicionado. Dissertação de mestrado - Faculdade de Economia e Contabilidade da Universidade de São Paulo. São Paulo: FEA/USP, 1.991. p. 33.

55 YOSHIOCA, Ricardo. Valor adicionado - Alguns conceitos econômicos que ajudam a entender a demonstração contábil. IOB informações objetivas . São Paulo: boletim TC 08/98, 1-5. p. 1
} 
O conceito de valor adicionado, elaborado pelo Instituto Brasileiro de Geografia e Estatística - IBGE ${ }^{56}$, ressalta bem essa abordagem:

'É o valor que a atividade acrescenta aos bens e serviços consumidos no seu processo produtivo. É a contribuição ao Produto Interno Bruto ${ }^{57}$ pelas diversas atividades econômicas, obtida pela diferença entre o valor de produção e o consumo intermediário absorvido por essas atividades".

No que é coincidente com o conceito de Rodríguez ${ }^{58}$, 'O valor adicionado, e $m$ Contabilidade Nacional ou Macroeconômica, é a diferença, para o produtor, entre o valor da produção avaliada a preços de mercado e aquele de seu consumo intermediário”.

De onde se apreende que o Produto Nacional é formado pelo somatório dos valores adicionados por todas as atividades econômicas durante as diversas etapas do processo produtivo, conforme é ressaltado por Simonsen ${ }^{59}$ :

'Denomina -se valor adicionado em determinada etapa de produção à diferença entre o valor bruto da produção e os consumos intermediários nessa etapa. Assim, o Produto Nacional pode ser concebido como a soma dos valores adicionados, em determinado período de tempo, em todas as etapas dos processos de produção do país".

Entendendo-se que o desenvolvimento econômico de um país está diretamente relacionado com a sua capacidade de gerar riqueza, o conceito de valor adicionado pode ser visto como essa medida da criação de valor, atendendo ao propósito de demonstrar, quantitativamente, o esforço produtivo de uma nação, servindo, inclusive, para avaliar seu desenvolvimento econômico, comparativamente ao de outras.

\footnotetext{
${ }^{56}$ IBGE. Sistema de contas nacionais - Brasil. Rio de Janeiro: Departamento de contas nacionais do IBGE, 1997. p. 302.

${ }^{57}$ Cabe fazer uma distinção entre Produto Nacional e Produto Interno, que não altera a abordagem desse estudo. O Produto Interno é todo gerado no interior do país, enquanto parte do Produto Nacional é ganha no exterior.

${ }^{58}$ RODRÍGUEZ, Alberto Almada. Quatro aspectos do levantamento da demonstração do valor adicionado nos setores públicos e privados. Revista Brasileira de Contabilidade. Brasília: ano XXIV, $\mathrm{n}^{\circ}$ 62, 4460, mar/abr 1996. p. 48.

${ }^{59}$ SIMONSEN, Mário Henrique. Macroeconomia. Rio de Janeiro: Apec, V. I, 1975. p. 83. In DE LUCA, Márcia Martins Mendes. Demonstração do valor adicionado. Dissertação de mestrado - Faculdade de Economia e Contabilidade da Universidade de São Paulo. São Paulo: FEA/USP, 1.991. p. 35, 36.
} 
Esses aspectos são ressaltados por Haller e Stolowy ${ }^{60}$ :

'Valor agregado (wertschöpfung, valeur ajouté) é uma medida do desempenho econômico de uma entidade econômica, utilizado há bastante tempo na economia. Tem sido reconhecido como um incremento na riqueza das entidades econômicas." (Tradução livre)

Além disso, o valor adicionado, entendido como o valor que cada segmento da atividade econômica produtiva agrega à produção, representa uma das variáveis que melhor expressa o comportamento do sistema como um todo, sendo possível, por meio dele, dimensionar, em termos de valor, com quanto cada setor econômico contribui para formar o conjunto de riquezas geradas por uma nação ${ }^{61}$. Ou seja, serve aos propósitos de medida de desempenho global do país, e ainda para avaliar o desempenho de cada setor ou etapa produtiva e a sua participação no todo.

Observa-se, então, que o conceito de valor adicionado, dentro da abordagem econômica, é utilizado para mensurar as atividades econômicas de um país, avaliando o Produto Nacional, ou seja, visão macroeconômica, quando se considera o ambiente analisado. E, com relação ao seu cálculo, considera-se a produção corrente de todo o sistema econômico num período.

\subsubsection{Conceito contábil}

De acordo com as premissas contábeis, a apuração do valor adicionado requer a mensuração das transações econômicas ocorridas dentro dos limites de uma empresa, visão microeconômica; e, no seu cálculo, considera o valor total das vendas de uma empresa num período, e não toda a produção. Para efeitos desse trabalho, interessa o valor adicionado pelas empresas, sob a visão contábil.

\footnotetext{
${ }^{60}$ HALLER, Axel. STOLOWY, Hervé. Valued added in financial accounting, a comparative study of Germany and France - Advances in international accounting. Vol. II. JAI press inc. 1998. p. 24.

${ }^{61}$ CARDOSO JR., José Celso. Geração e apropriação de valor adicionado na economia brasileira: um estudo da dinâmica distributiva no período 1990/1996. IPEA, Instituto de Pesquisa Econômica Aplicada. Rio de Janeiro: 2000, p. 8. (Texto para discussão $\mathrm{n}^{\circ}$ 733).Disponível em http://www.ipea.gov.br/pub/td/td_2000/td0733.pdf. Acesso em: 11/03/02.
} 
Tinoco $^{62}$ conceituou o valor adicionado contábil: "A diferença entre o valor das vendas e o valor das compras de bens, mercadorias e serviços intermediários representa o valor adicionado pela empresa para a sociedade.”

Esclarece, ainda, o significado disso para essa sociedade:

“...para exercer sua atividade toda empresa deve procurar no mercad o bens e serviços. Ela utiliza os equipamentos, seus capitais, o trabalho de seus assalariados para realizar outros bens e serviços, que por seu lado serão vendidos. A empresa se coloca pois entre dois mercados e agrega valor pela operação de transformação, via simples distribuição que ela opera." 63

Para Belkaoui ${ }^{64}$,

' $O$ valor adicionado se refere ao incremento na riqueza gerada pelo uso produtivo dos recursos das firmas antes da sua alocação entre acionistas, credores, trabalhadores, e o governo. Assim, enquanto o lucro é o retorno final ganho pelos acionistas, o valor adicionado se refere ao retorno total ganho pelos trabalhadores, provedores de capital, e o governo". (Tradução livre)

O valor adicionado permite, portanto, à sociedade, avaliar, principalmente por meio da análise de sua distribuição, se essa operação de transformação realizada pela empresa, e que cria riqueza, está devolvendo a ela pelo menos o equivalente aos recursos que lhe foram tirados, servindo, inclusive, como forma de incentivo ao comportamento de outras empresas, conforme é ressaltado por Ribeiro e Lisboa ${ }^{65}$ :

"A análise da distribuição do valor adicionado identifica a contribuição da empresa para a sociedade e os setores por ela priorizados. Este tipo de informação serve para avaliar a performance da empresa no seu contexto local, sua participação no desenvolvimento regional e estimular ou não a continuidade de subsídios e incentivos governamentais. E, em contexto maior, pode servir de parâmetro para definição do comportamento de suas congêneres".

\footnotetext{
${ }^{62}$ TINOCO, João Eduardo Prudêncio. Balanço social e contabilidade de recursos humanos. In: SEMINÁRIO BALANÇO SOCIAL - UMA IDÉIA VIVA (3ํ. GRUPO). 1997, São Paulo. Apostila...São Paulo: JCA Treinamentos e FIPECAFI - FEA/USP, 1997. p. 8.

${ }^{63}$ TINOCO, João Eduardo Prudêncio. Balanço social - Uma abordagem sócio-econômica da contabilidade. Dissertação de mestrado - Faculdade de Economia e Administração da Universidade de São Paulo. São Paulo: FEA/USP, 1984. p. 38 e 39

${ }_{65}^{64}$ BELKAOUI, Ahmed. The new environment in international accounting. Quorum Books, 1998. p. 1.

${ }^{65}$ op. cit. p. 12
} 
Essa característica do valor adicionado como medida de avaliação do desempenho da empresa $^{66}$ também é abordada por Rodríguez ${ }^{67}$ :

'O valor adicionado (...), vem sendo considerado pelos analistas um dos critérios que melhor indicam a medida da eficácia da gestão empresarial, superior àquele do lucro (ou cashflow líquido), valor misto, integrado que é por aquela parte que vai para os associados (lucro distribuído) e a outra retida na empresa (lucros em reserva e dotação de exercício), tudo isso dentro da concepção de que a missão moderna na empresa representa um papel econômico e social”.

E, também por Haller e Stolow ${ }^{68}$,

'Devido a suas características de mensuração de criação da riqueza, o conceito de valor agregado tem sido discutido como uma maneira para estimar a produtividade das entidades econômicas através de sua eficiência no uso dos fatores produtivos tais como força de trabalho e capital". (Tradução livre)

Ribeiro e Lisboa $^{69}$ apresentam de forma sucinta a operação de transformação realizada pelas empresas, partindo da receita de vendas e chegando ao total dos recursos distribuídos. O resultado da receita de vendas, deduzido dos custos dos recursos adquiridos de terceiros e consumidos durante o processo produtivo, corresponde à riqueza gerada pela empresa. Ou seja, o quanto a empresa adicionou aos insumos/serviços adquiridos de terceiros, e que podem ser constituídos por matéria-prima, mercadorias para revenda, serviços, energia elétrica, dentre outros, para chegar ao seu produto/serviço final. Esse resultado é chamado de valor adicionado bruto.

Durante seu processo produtivo, a empresa também utiliza máquinas, equipamentos, instalações, e outros ativos fixos, consumindo parcialmente seu potencial de uso. Esse fenômeno é refletido contabilmente pela depreciação, amortização e exaustão.

Como, para a geração da riqueza, foi necessário o consumo, mesmo que parcial, desses ativos, esse valor deve ser deduzido do valor adicionado bruto, refletindo,

\footnotetext{
${ }_{67}^{66}$ Aspecto ressaltado dentro da visão econômica como avaliador do desempenho do país.

${ }^{67}$ op. cit. p. 47

68 op. cit. p. 24.

${ }^{69}$ RIBEIRO, Maisa de Souza, LISBOA, Lázaro Plácido. Balanço social. Revista Brasileira de Contabilidade. Brasília: ano XXVIII, n 115, 72-81, jan/fev 1999, p. 19-20.
} 
efetivamente, o quanto a empresa gerou para a economia local, o que é denominado de valor adicionado líquido.

Entretanto, existem, ainda, aqueles valores que a empresa recebe de terceiros e que não representam sacrifícios operacionais. Em algum momento no passado a empresa realizou algum investimento que está sendo recompensado agora, como é o caso das receitas financeiras, dos ganhos com participações acionárias, do aluguel de imóveis para renda, etc. Esses valores recebem o nome de receitas recebidas em transferência e, somados ao valor adicionado líquido, vão demonstrar o total dos recursos gerados.

Os segmentos beneficiários desses recursos são os empregados, que recebem salários e outros benefícios como contraprestação à sua força de trabalho cedida à empresa; os acionistas, que recebem lucros em troca do capital que deixaram à sua disposição; os financiadores externos, que recebem o pagamento de suas dívidas; o Estado, que recebe os tributos para que possa equilibrar a desigualdade social; os investidores, que aportam recursos e são remunerados com juros; ou ainda, a própria empresa, quando os lucros ficam retidos para aplicações futuras.

Nesse momento, algumas considerações são necessárias:

- a economia trabalha com valores estimados (o PIB é apurado atualmente, pelo IBGE, por estimativa ${ }^{70}$ );

- os valores de produção utilizados pela economia não serão necessariamente vendidos;

- o PIB seria obtido automaticamente, por meio de soma, se todas as atividades econômicas calculassem o valor adicionado.

- os cálculos de valor adicionado realizados pela contabilidade são baseados em valores efetivamente realizados;

- as empresas, de uma forma geral, efetuam os registros de suas vendas, obedecendo ao princípio contábil da realização da receita, que também é utilizado para elaboração das demonstrações contábeis;

\footnotetext{
${ }^{70}$ RIBEIRO, Maisa de Souza. Balanço social. Jornal do Economista, São Paulo: no . 122, 19 abr. 1999.
} 
- na visão contábil, o valor adicionado aos produtos só é reconhecido no momento em que estes são vendidos, ignorando o fato de que a passagem do tempo e a conjuntura econômica, além de outros fatores, alteram continuamente a riqueza da empresa;

Independente da abordagem utilizada, econômica ou contábil, o valor adicionado pode ser calculado de duas maneiras: pelo método subtrativo e pelo método aditivo ${ }^{71}$. O método subtrativo expressa o valor adicionado aos produtos e serviços adquiridos de outras empresas por meio de suas próprias atividades produtivas, conforme demonstrado:

$$
\mathrm{VA}=\mathrm{S}-\mathrm{E}
$$

Onde,

$\mathrm{VA}=$ valor adicionado

$\mathrm{S}=$ saídas

$\mathrm{E}=$ entradas

Como toda riqueza é alocada, o valor adicionado também pode ser calculado pelo método aditivo, que representa o somatório das partes distribuídas da riqueza gerada, representando, em princípio, a remuneração dos fatores de produção que participaram da criação da riqueza:

$$
\mathrm{VA}=\mathrm{RE}+\mathrm{RG}+\mathrm{RCP}+\mathrm{NAP}
$$

Onde,

$\mathrm{VA}=$ valor adicionado

$\mathrm{RE}=$ remuneração dos empregados

$\mathrm{RG}=$ remuneração do governo

$\mathrm{RCP}=$ remuneração do capital dos provedores

NAP = lucros não apropriados (retidos)

${ }^{71}$ HALLER, Axel, STOLOWY, Hervé. op. cit. p. 24 e 25. 
Esses dois métodos permitem avaliar o conteúdo característico do conceito de valor adicionado, que aborda tanto o desempenho quanto o social. $\mathrm{O}$ aspecto do desempenho pode ser observado por meio do método subtrativo, que demonstra a capacidade da entidade em gerar riqueza pela sua atividade. O aspecto social é expresso pelo método aditivo, onde percebe-se que a informação dada pelo valor adicionado não é apenas econômica, pois identifica a parte da riqueza gerada que é entregue a cada participante do processo produtivo da empresa.

O instrumental posto à disposição dos usuários, pela contabilidade, dentro do enfoque de entendimento da geração e distribuição de riquezas e com o intuito de estreitar as relações entre empresas e sociedade, é indiscutivelmente a Demonstração do Valor Adicionado, que difere do conceito de valor agregado por mostrar a distribuição da riqueza criada pelos agentes econômicos que ajudaram na sua criação.

\subsubsection{Demonstração do Valor Adicionado}

Conceitualmente, a Demonstração do Valor Adicionado (DVA) é uma das peças formadoras do balanço social, mas em muitos casos o que se vê é sua apresentação dissociada dele e em conjunto com as outras Demonstrações Contábeis usuais, ou ainda, como o próprio balanço social.

Para De Luca ${ }^{72}$, "A Demonstração do Valor Adicionado (DVA) é um conjunto de informações de natureza econômica. É um relatório contábil que visa demonstrar o valor da riqueza gerada pela empresa e a distribuição para os elementos que contribuíram para sua geração."

Estabelecendo um paralelo com o conceito de valor adicionado utilizado pelo segmento econômico, Kroetz ${ }^{73}$ comenta, 'Por meio da Demonstração do Valor

\footnotetext{
${ }^{72}$ DE LUCA, Márcia Martins Mendes. Demonstração do valor adicionado: do cálculo da riqueza criada pela empresa ao valor do PIB. 1. ed. São Paulo: Atlas, 1998. p. 28

${ }^{73}$ op. cit. p. 42
} 
Agregado é possivel perceber a contribuição econômica da entidade para cada segmento com o qual ela se relaciona, constituindo-se no Produto Interno Bruto (PIB), produzido pela organização.” Ou seja, a demonstração do valor adicionado evidencia a riqueza que foi gerada individualmente por uma entidade.

E ainda, dentro da mesma visão, Santos e Lustosa ${ }^{74}$, avaliam:

"A distribuição do valor adicionado equivale ao conceito macroeconômico de Renda Nacional. A transformação de recursos intermediários em produtos e serviços finais só é possível pelo emprego dos fatores de produção (trabalho, capital, governo, empresa). Em termos gerais, a remuneração destes fatores (salário, juro, aluguel, imposto e lucro) pelas empresas constitui a renda em poder da sociedade, que retorna às empresas tanto na aquisição de seus produtos e serviços como sob a forma de novos financiamentos, reiniciando o ciclo econômico".

Trata-se, pois, de um relatório contábil, que demonstra tanto os benefícios que as organizações oferecem para a sociedade, por meio, por exemplo, da absorção da mão de obra da comunidade em que estão inseridas, quanto a sua capacidade de gerar riqueza para a economia, ou seja, contribuir para o desenvolvimento econômico.

Mas não é apenas isso. A DVA permite, além da identificação da riqueza gerada exclusivamente pela empresa, a identificação daquela riqueza recebida em transferência, apresentando, ainda, um mapeamento de como essas riquezas são distribuídas aos seus diversos beneficiários: empregados, governo, financiadores externos, acionistas e a própria empresa.

Há autores que não reconhecem o potencial social das informações contidas na demonstração, por exemplo, Freire e Rebouças ${ }^{75}$, "A DVA pode ser um importante componente contábil do balanço social, mas apresenta informações que estão muito aquém daquelas que seriam necessárias para seu reconhecimento como balanço social”.

\footnotetext{
${ }^{74}$ op. cit. p. 4

${ }^{75}$ op. cit. p. 105
} 
De fato, as informações prestadas pela DVA estão aquém daquelas prestadas pelo balanço social, porém, porque a mesma nunca teve pretensões de ser o próprio, mas apenas de compô-lo, como que é destacado por $\operatorname{Santos}^{76}$ :

"A Demonstração do Valor Adicionado, componente importantíssimo do balanço social, deve ser entendida como a forma mais competente criada pela contabilidade para auxiliar na medição e demonstração da capacidade de geração, bem como de distribuição, da riqueza de uma entidade”.

Uma empresa, normalmente, tem capacidade de geração de riqueza bem maior que o lucro que ela distribui aos seus sócios e acionistas. Tradicionalmente, o lucro obtido pela empresa tem sido apresentado por meio da Demonstração do Resultado do Exercício - DRE. Para Iudícibus, Martins e Gelbcke"77, "A Demonstração do Resultado do Exercício é a representação, em forma resumida, das operações realizadas pela empresa, durante o exercício social, demonstradas de forma a destacar o resultado líquido do exercício.” Entretanto, essa demonstração não analisa a contribuição dos agentes econômicos na geração da riqueza da empresa e, por isso, não evidencia a parcela que tocou a cada um deles no processo produtivo, pois está voltada para a apuração e divulgação do lucro, que pertence ao proprietário.

$\operatorname{Santos}^{78}$, discorrendo sobre a visão particular do lucro na Demonstração do Resultado do Exercício, conclui:

'Nesse aspecto, a Demonstração do Valor Adicionado - DVA é muito mais abrangente, pois não está exclusivamente voltada para a apuração do resultado, porquanto considera outros fatores de produção e aponta suas respectivas remunerações. São componentes dessa demonstração, além da informação relativa à riqueza gerada pela empresa, a forma com que essa riqueza é distribuída através de impostos pagos ao governo, juros e aluguéis destinados a financiadores externos, remunerações pagas aos trabalhadores e lucros e dividendos (ou juros sobre o capital próprio, como previsto na legislação brasileira) atribuídos aos proprietários, sócios e acionistas."

\footnotetext{
${ }^{76}$ SANTOS, Ariovaldo dos. Demonstração contábil do valor adicionado- DVA- Um instrumento para medição da geração e distribuição de riqueza das empresas. Tese de Livre Docência - Faculdade de Economia e Contabilidade da Universidade de São Paulo. São Paulo: FEA/USP, 1999. p. 98

${ }^{77}$ IUDÍCIBUS, Sérgio de, MARTINS, Eliseu, GELBCKE, Ernesto Rubens. Manual de contabilidade das sociedades por ações. São Paulo: 5 ed., Atlas, 2000. p. 290.

${ }^{78}$ op. cit. p. 20.
} 
Entretanto, na avaliação do autor retro citado ${ }^{79}$, DRE e DVA são demonstrações que se completam, tratando, inclusive, dos mesmos itens, apenas com enfoques diferentes. A DRE, por exemplo, trata juros, salários e outros, como despesas e/ou custos da empresa para gerar receitas, o que na visão do proprietário diminui seu lucro, enquanto na DVA esses itens representam a forma pela qual os beneficiários da riqueza receberam a sua parcela.

A Demonstração do Valor Adicionado, portanto, representa um novo rumo em comparação com as Demonstrações Contábeis tradicionais pois, enquanto estas têm como foco principal de preocupação a evidenciação, para os investidores, das informações sobre o lucro e sua forma de apuração, aquela mostra, além do lucro dos investidores, a quem pertence a outra parte da riqueza gerada pela empresa, refletindo, ainda, uma preocupação empresarial que é nova, e baseada na responsabilidade social, a remuneração dos fatores de produção que ajudaram a formar a riqueza da organização.

Da mesma forma que num passado próximo, os proprietários do capital sentiram necessidade de informações financeiras para decidir sobre o melhor investimento e que sofresse menor risco, surgindo, assim, as demonstrações contábeis na forma como são conhecidas hoje, surge agora a necessidade, não só de proprietários, mas também de empregados, governo, fornecedores e da comunidade como um todo, de informações que orientem a uma avaliação de desempenho baseada em conceitos que reúnem a preocupação com a responsabilidade social.

Constituem-se, ainda, num excelente suporte contábil, posto a disposição dos sindicatos de trabalhadores quando de suas negociações junto aos empregadores de questões relativas a salários, empregos, produtividade, segurança no emprego e outros benefícios, dando a estes poder de barganha pelo simples fato de serem também detentores das informações, não necessitando, portanto, continuarem reféns das informações que se encontram nas mãos dos detentores do capital.

\footnotetext{
${ }^{79}$ SANTOS, Ariovaldo dos. Demonstração de Resultados X Demonstração de Valor Adicionado. Anefac news. São Paulo: ano I, no 02, 3-4, maio 2001. p. 3
} 
No campo das análises macroeconômicas, existem, ainda, diversas aplicações e utilidades para a DVA, dentre as quais cabe destacar ${ }^{80}$ :

- cálculo do PIB - uma grande parte dos agentes econômicos, as empresas, pode calcular seu valor adicionado e apresentá-lo por meio da DVA, o que facilitaria, em muito, no cálculo e análise do PIB;

- análise de investimentos, concessões de financiamentos e subsídios governamentais - a contribuição da empresa, tanto à sociedade em geral quanto à comunidade em que está inserida, pode ser verificada por meio de: montante de pagamento de impostos ao governo, volume de distribuição de empregos, dentre outros, principalmente para estudos de viabilidade econômica de projetos de instalação de empresas em regiões, liberação de financiamentos e benefícios governamentais;

- avaliação de projetos de instalação de empresas transnacionais - o investidor estrangeiro, para se estabelecer, oferece capital, Know-how e estrutura que propiciam desenvolvimento econômico para o país. Em contrapartida, o país oferece acesso a seu mercado interno, seus recursos naturais, benefícios fiscais, dentre outros. Os resultados dessa relação podem ser avaliados por meio da DVA.

Segundo De Luca ${ }^{81}$ :

"À sociedade de um modo geral, a Demonstração do Valor Adicionado permite a avaliação das condições do Estado em proporcionar benefícios para a comunidade com base no valor dos impostos apresentados. Permite ainda, avaliar a contribuição da empresa para a região; se a empresa está gerando riqueza ou, se, vende muito mas compra muito e pouco agrega valor aos seus insumos gerando pouca riqueza para a comunidade onde está inserida."

Dessa forma, torna-se possível uma melhor avaliação do conjunto de empresas formadoras de uma sociedade. Os Valores Adicionados por elas, calculados por meio da DVA, constituem-se numa parte significativa de toda a riqueza gerada por um

\footnotetext{
${ }^{80}$ DE LUCA, Márcia Martins Mendes. A contribuição da demonstração do valor adicionado no processo de mensuração do PIB e em algumas análises macroeconômicas. Tese de doutoramento - Faculdade de Economia e Contabilidade da Universidade de São Paulo. São Paulo: FEA/USP, 1996. p. 141-145.

${ }^{81}$ DE LUCA, Márcia Martins Mendes. Demonstração do valor adicionado. Dissertação de mestrado Faculdade de Economia e Contabilidade da Universidade de São Paulo. São Paulo: FEA/USP, 1.991. p. 45-46.
} 
país. É também por meio da DVA que podemos mostrar e avaliar como essa riqueza está sendo distribuída por meio dos impostos pagos ao governo, lucros e dividendos aos acionistas, e ainda remunerações pagas aos trabalhadores, que é o foco desse estudo.

Parafraseando Ribeiro e Lisboa $^{82}$, em princípio, uma empresa só deveria ser autorizada a exercer suas atividades se o custo-benefício de sua existência para a sociedade se apresentasse positivo.

\subsubsection{A DVA no exterior}

A DVA surgiu na Europa, há anos atrás, apesar de ser encontrada, na literatura, referência sobre ela no tesouro americano no Século XVIII ${ }^{83}$. Seu desenvolvimento foi impulsionado pela urgência na introdução do imposto sobre valor agregado nos países europeus, e, a partir do final dos anos 70, atingiu uma grande popularidade no Reino Unido, com a publicação do Corporate Report pelo Accounting Standards Steering Committee, atualmente Accounting Standards Committee, em agosto de $1975^{84}$. Esse relatório recomendava, dentre outras coisas, a elaboração da DVA, para evidenciar como os benefícios e os esforços de uma empresa são divididos pelos empregados, provedores de capital, Estado e reinvestimentos. A justificativa para sua recomendação foi a seguinte:

"A mais simples e imediata maneira de colocar o lucro dentro de uma perspectiva apropriada, frente à frente à empresa entendida como um esforço coletivo do capital, administração e empregados é pela apresentação da demonstração do valor agregado. O valor agregado (isto é, resultado de vendas menos materiais e serviços comprados) é a riqueza que a entidade foi capaz de criar pelos esforços de seus proprietários e seus empregados. Essa demonstração revelaria como o valor agregado está sendo usado para pagar contribuições concedidas para sua criação...” (Tradução livre)

\footnotetext{
${ }^{82}$ RIBEIRO, Maisa de Souza, LISBOA, Lázaro Plácido. Balanço social: instrumento de divulgação da interação da empresa com a sociedade. In: Encontro da ANPAD, 23º 1999, Salvador. Anais..., 1999, p. 2.

${ }^{83}$ B. Cox. Value Added: an application for the accountant concerned with industry. London: Heinemann and the Institute of Cost and Management Accountants, 1978. In: BELKAOUI, Ahmed. The new environment in international accounting. Quorum Books, 1998. p. 4

${ }^{84}$ BELKAOUI, Ahmed. The new environment in international accounting. Quorum Books, 1998. p. 4
} 
A recomendação foi aceita e uma das propostas do legislativo do Reino Unido contidas no relatório The future of company reports, de 1977, foi para a DVA.

A DVA veio, então, se juntar ao balanço patrimonial, à demonstração de resultados, e às outras demonstrações contábeis.

Cresce, assim, o número de companhias que, a cada ano, elaboram sua DVA. Uma pesquisa realizada em 1980 relatou que mais de 1/5 das grandes companhias do Reino Unido divulgam esse relatório ${ }^{85}$. Esse aumento também pode ser creditado aos esforços empreendidos pelas associações de trabalhadores, que estimularam o crescimento do número de relatórios, por verem nele um bom veículo para evidenciar a informação e uma base para determinar salários e remunerações. Conforme Glautier e Underdow ${ }^{86}$ :

"Algumas companhias estão introduzindo conceitos de valor agregado no esquema de incentivo a salários à medida que melhore a produtividade. O primeiro passo é harmonizar uma meta para relacionar salários e valor agregado por um quociente. Se o desempenho exceder essa percentagem um bônus será pago, mas se o desempenho ficar abaixo dessa expectativa, não haverá bônus e o déficit será transferido para reduzir os bônus futuros." (Tradução livre)

Como a DVA evidencia a geração de riqueza pela empresa, e sua forma de distribuição aos agentes que colaboraram na sua criação, constitui-se numa visão nova para os trabalhadores sobre o desempenho das entidades. Por meio dessa demonstração é possível aos trabalhadores avaliarem a oscilação da riqueza que a empresa produziu e acompanhar a parcela que está sendo levada por eles. Dessa forma, conscientemente, lutar por aumentos reais de salários e de incentivos, em virtude desse acréscimo na riqueza. Como se observará ao longo deste estudo, esse relacionamento deverá ser feito não pelo montante de salários pagos aos trabalhadores, que poderá ser influenciado pelas contratações e demissões, e sim por meio do valor adicionado por empregado.

\footnotetext{
${ }^{85}$ S.J. Gray and K.T. Maunders. Value Added Reporting: uses and measurement. London: Association of Certified Accountants, 1980 In: BELKAOUI, Ahmed. The new environment in international accounting. Quorum Books, 1998. p.5

${ }^{86}$ GLAUTIER, M.W.E., UNDERDOW B. Accounting theory and practice. Great Britain: 3. ed. Pitman, 1986. p. 468.
} 
Foi durante o crescimento de popularidade, acontecido nos anos $70^{87}$, que a DVA foi considerada, em muitos países europeus, como uma das ferramentas centrais para a divulgação de informações tidas como relevantes para a sociedade. Não somente os acadêmicos, mas especialmente os comitês e institutos contábeis, passaram, então, a preocuparem-se com as proposições para a apresentação da DVA.

Esse aumento de popularidade, entretanto, não foi o que se observou durante a pesquisa efetuada, dada a dificuldade em conseguir exemplos de entidades que elaboram a demonstração.

Conforme De Luca ${ }^{88}$, o Grupo de Trabalho Intergovernamental de Especialistas em Padrões Internacionais de Contabilidade e Informação da Organização das Nações Unidas - ONU, também se posicionou sobre a elaboração da DVA. Recomendou, em 1988, na publicação Conclusion on Accounting and Reporting by Transnational Corporations, a divulgação do valor adicionado das operações da empresa, assim como de sua distribuição. Na avaliação desse grupo, o valor adicionado, normalmente, é derivado das vendas menos os custos dos materiais e serviços adquiridos de terceiros, resultados de outras empresas, lucros na realização de investimentos, itens extraordinários e ganhos e perdas na conversão.

Haller e Stolowy ${ }^{89}$ discorrem que a noção e o conceito de valor adicionado tem grande importância, tanto na França quanto na Alemanha. Neste último, desde a década de 50, o interesse acadêmico e prático aumentou substancialmente, possivelmente por razões políticas - uma tentativa da sociedade em livrar-se da herança do "Terceiro Reich". Mas foi nos anos 70 e início dos 80, quando as discussões sobre responsabilidade social das empresas tomaram corpo, que os conceitos de valor adicionado tiveram seu renascimento, não apenas na Alemanha, mas também na Grã-Bretanha, nos EUA e França, principalmente.

\footnotetext{
${ }_{88}^{87}$ BELKAOUI, Ahmed. op.cit. p. 4

${ }^{88}$ DE LUCA, Márcia Martins Mendes. Demonstração do valor adicionado. Dissertação de mestrado Faculdade de Economia e Contabilidade da Universidade de São Paulo. São Paulo: FEA/USP, 1991. p. 50-51.

${ }^{89}$ op. cit. p. $24-47$
} 
Esses autores realizaram um estudo comparativo sobre o valor adicionado na França e Alemanha, nos relatórios anuais de 1993 de grupos empresariais, e, embora tenham concluído que a definição básica de valor adicionado é similar nesses dois países, existem várias diferenças, principalmente quanto à sua divulgação.

Na França, apesar da utilização de conceitos de valor adicionado como ferramenta para análise das demonstrações contábeis, não existe uma demonstração de valor adicionado propriamente dita, e a maioria dos relatórios anuais analisados apresentam o montante do valor adicionado como parte de uma demonstração de resultados, inexistindo, na amostra, algum grupo que tenha apresentado uma informação completa (cálculo do valor adicionado e sua distribuição), ou mesmo incompleta (com apenas o cálculo ou a distribuição). Na Alemanha, todas as informações sobre valor adicionado são prestadas por meio da demonstração do valor adicionado, seja a demonstração completa (50\% da amostra), ou incompleta (50\% da amostra). Mas, principalmente, concluíram que, em ambos os países, as empresas relutavam bastante em divulgar informações sobre valor adicionado, ou mesmo a demonstração por inteiro, e que, na Alemanha, os relatórios apresentavam baixo nível de comparabilidade, o que reforçava o argumento à crítica, muitas vezes feita nesse país, de que a divulgação da demonstração de valor adicionado era usada, pelas empresas, mais com propósitos de relações públicas do que com o objetivo de aumentar o número de informações úteis.

Em vários países da África, e também na Índia, a DVA é considerada um relatório com informações tão relevantes, que é exigida sua apresentação de qualquer empresa que queira se instalar em seu território, para avaliar quanta riqueza ela é capaz de criar dentro do país. Para eles, pouco adianta quem vende muito, mas compra muito (a exemplo de algumas montadoras de automóveis), pois está gerando pouca riqueza nova $^{90}$.

\footnotetext{
${ }^{90}$ MARTINS, Eliseu.. Uma nova demonstração contábil no projeto de reforma da Lei das S/A: a do valor adicionado. IOB Informações objetivas. São Paulo: TC boletim 29/97. p. 4-5
} 
2.2.3.2 Exemplos de DVA publicadas por empresas no exterior

Conforme pesquisa conduzida pela autora por meio da Internet, a seguir serão apresentadas algumas demonstrações do valor adicionado de empresas situadas em países distintos.

A Lakeland Dairies Co-Operative Society Ltd. é uma empresa instalada no norte da Irlanda, e produz derivados do leite e outros gêneros alimentícios. Além do consumo interno, exporta grandes volumes para o Reino Unido, Europa, América do Norte e do Sul, Ásia, África, dentre outros. Está sendo mostrada, na Figura 2, sua DVA referente ao ano 2000, comparativa com a do período anterior. Nesse modelo, é apresentada, ainda, a margem percentual de cada item, em relação ao total da receita. Os valores estão grafados em milhares de libras irlandesas, que era a moeda oficial do país até a adoção do euro, em 2001. Observa-se que o valor adicionado é criado pela diferença entre as vendas e os pagamentos a fornecedores externos, não existindo mais nenhum valor que o compõe. A distribuição é feita aos empregados, governo, provedores de capital, e ainda retido para manutenção dos ativos (depreciação) e dos ganhos futuros. Os pagamentos efetuados aos fazendeiros também são tratados como distribuição, respondendo por mais de $80 \%$ dela.

Com sede em Singapura e com companhias subsidiárias e associadas localizadas em pontos chave do sudeste da Ásia, China, Japão, Austrália, Europa e Reino Unido, apresenta-se a Times Publishing Limited na Figura 3, empresa estabelecida em 1968, e considerada uma das pioneiras em publicações de língua inglesa no país. Seus principais artigos são publicações eletrônicas e impressas, distribuição de música gravada, áudio, vídeo tapes e acessórios de som, fornecimento de programas educacionais, organização de conferências e exposições, dentre outros. Sua demonstração está apresentada em milhares de dólares, e também é comparativa com a do exercício anterior. O total do seu valor adicionado é formado pela diferença entre as vendas e os materiais consumidos, e por outros itens não ligados à produção 
Figura 2- DVA da Lakeland Dairies Co-Operative Society Ltd. - 2000

Value added is a measure of the wealth created by the group and its employees by purchasing, processing and reselling its products and services.

\begin{tabular}{|c|c|c|c|c|}
\hline & $\begin{array}{r}2000 \\
\text { IR£' } 000\end{array}$ & $\begin{array}{r}\% \\
\text { Turnover }\end{array}$ & $\begin{array}{r}1999 \\
\text { IR£'000 }\end{array}$ & $\begin{array}{r}\% \\
\text { Turnover }\end{array}$ \\
\hline Sales Revenue & 173,207 & 100 & 163,191 & 100 \\
\hline Payment to External Suppliers & $(82,310)$ & 48 & $(83,063)$ & 51 \\
\hline \multirow[t]{2}{*}{ Value Added } & 90,897 & 52 & 80,128 & 49 \\
\hline & $\mathbf{R} \mathfrak{f}^{\prime} \mathbf{0 0 0}$ & $\begin{array}{r}\% \text { Value } \\
\text { Added }\end{array}$ & IR£'000 & $\begin{array}{r}\% \text { Value } \\
\text { Added }\end{array}$ \\
\hline
\end{tabular}

DISTRIBUTED AS FOLLOWS:

\begin{tabular}{|c|c|c|c|c|}
\hline Payments to Farmers & 74,257 & 81.7 & 65,613 & 81.9 \\
\hline \multicolumn{5}{|l|}{ Employees } \\
\hline - Wages \& Salaries & 9,502 & 10.5 & 8,551 & 10.6 \\
\hline \multicolumn{5}{|l|}{ Government } \\
\hline - Taxation & 369 & 0.4 & 305 & 0.4 \\
\hline \multicolumn{5}{|l|}{ Providers of Capital } \\
\hline - Interest on Borrowings & 362 & 0.3 & 178 & 0.2 \\
\hline - Dividends to Members & 54 & 0.1 & 54 & 0.1 \\
\hline \multicolumn{5}{|l|}{ Maintenance of Assets } \\
\hline - Depreciation & 2,663 & 2.9 & 2,619 & 3.3 \\
\hline \multirow[t]{2}{*}{ etained for Future Growth } & 3,720 & 4.1 & 2,808 & 3.5 \\
\hline & 90,897 & 100 & 80,128 & 100 \\
\hline
\end{tabular}

NOTE: Included in Payments to External Suppliers are Raw Material Purchases, Fertilizer Purchases, Transport Costs, Packaging \& Power

Fonte: Adaptado de Lakeland Dairies Co-Operative Society Ltd. Value added statement. Disponível em http://www.lakeland.ie/value.htm .Acesso em: 05/02/02 
Figura 3 - DVA da Times Publishing Limited - 30-09-2000

\begin{tabular}{|c|c|c|}
\hline Thous and of dollars & 30.9 .2000 & 31.8.1999 \\
\hline Group Turnover from trading & 469,113 & 493,460 \\
\hline Bought-in materials & $(309,940)$ & $(326,690)$ \\
\hline Value Added From Trading & 159,173 & 166,770 \\
\hline \multicolumn{3}{|l|}{ Non-production items } \\
\hline Investment and other income & 14,149 & 7,545 \\
\hline Share of profits of associated companies & 1,214 & 4 \\
\hline Extraordinary item & $(9,457)$ & 166 \\
\hline Profit on sale of fixed assets & $(132)$ & 9 \\
\hline Foreign exchange gain/(loss) from operations & 693 & $(2,158)$ \\
\hline Amortisation of intangible assets and preliminary expenses & 206 & (94) \\
\hline \multirow[t]{2}{*}{ Foreign exchange adjustment } & $(951)$ & 681 \\
\hline & 5,722 & 6,153 \\
\hline Total Value Added & 164,895 & 172,923 \\
\hline \multicolumn{3}{|l|}{ Applied as follows: } \\
\hline \multicolumn{3}{|l|}{ To Government } \\
\hline Income and other taxes & 18,180 & 19,001 \\
\hline \multicolumn{3}{|l|}{ To Employees } \\
\hline Salaries and other staff costs & 89,055 & 93,748 \\
\hline \multirow[t]{2}{*}{ Directors' fees and remuneration } & 5,393 & 4,427 \\
\hline & 94,448 & 98,175 \\
\hline \multicolumn{3}{|l|}{ To Suppliers of Capital } \\
\hline Interest on loan & 353 & 672 \\
\hline Dividends to shareholders & 13,776 & 13,529 \\
\hline \multirow[t]{2}{*}{ Dividends to minority shareholders } & - & 24 \\
\hline & 14,129 & 14,225 \\
\hline \multicolumn{3}{|l|}{ Retained in the business } \\
\hline Depreciation & 21,315 & 19,408 \\
\hline Bad debts & 29 & 43 \\
\hline \multirow[t]{2}{*}{ Retained earnings } & 9,271 & 12,347 \\
\hline & 30,615 & 31,798 \\
\hline \multicolumn{3}{|l|}{ Non-production costs and income } \\
\hline Provision for doubtful debts & 3,089 & 3,490 \\
\hline Investment and other income & 14,149 & 7,545 \\
\hline Extraordinary item & $(9,457)$ & 166 \\
\hline Foreign exchange gain/(loss) from operations & 693 & $(2,158)$ \\
\hline \multirow[t]{3}{*}{ Foreign exchange adjustment } & $(951)$ & 681 \\
\hline & 7,523 & 9,724 \\
\hline & 164,895 & 172,923 \\
\hline Value added per employee & 84.7 & 85.6 \\
\hline Value added per \$ employment cost & 1.75 & 1.76 \\
\hline Value added per $\$$ investment in fixed assets (before depreciation) & 0.43 & 0.48 \\
\hline Value added per $\$$ net sales & 0.35 & 0.35 \\
\hline
\end{tabular}

Fonte: Adaptado de Times Publishing Limited. Value added statement. Disponível em http://www.tpl.com.sg/tplhome/financial. Acesso em: 18/02/02. 
como, lucro em ações de companhias associadas, ganhos nas vendas de ativo fixos, amortizações de ativos intangíveis e despesas preliminares e ajustes por mudanças no câmbio. Sua distribuição é feita ao governo, empregados, investidores de capital, e é retido pela empresa por meio da depreciação e para fazer frente a devedores duvidosos, além dos lucros retidos. A demonstração apresenta ainda, informações sobre o valor adicionado por empregado, por custo do emprego, por investimentos em ativos fixos e por vendas líquidas.

Dois exemplos da República da África do Sul são mostrados a seguir. O primeiro deles, na Figura 4, da Allied Electronics Corporation Limited - Altron - estabelecida em 1924, para distribuição de componentes eletrônicos. Sua demonstração referente ao ano de 2001 é apresentada juntamente com a do período anterior, 2000, em milhões de rand, a moeda oficial do país. Conta com uma coluna onde estão apresentados os percentuais distribuídos a cada fator, totalizando os $100 \%$ de valor adicionado distribuível. O total do valor adicionado é formado pelas vendas diminuídas dos gastos com materiais e serviços, e de outros ganhos não explicitados. A distribuição é feita para os empregados, provedores de capital e governo, e, ainda, parte é retida pela empresa.

O outro exemplo desse país é da Gold Fields Limited, um dos maiores produtores de metais preciosos do mundo e líder sul-africano. A companhia foi formada em $1998 \mathrm{e}$ mantém uma produção de ouro anual de cerca de 3,66 milhões de onças. O demonstrativo consolidado de todo o grupo é referente ao exercício findo em 30 de junho de 2001 e é apresentado na Figura 5, comparativamente com o do período anterior. Seus valores também são apresentados em milhões de rand, e contam com uma coluna mostrando os percentuais referentes a cada item, em relação ao valor adicionado. $\mathrm{O}$ valor adicionado composto pelas receitas menos o custo de materiais e serviços e, pelos dividendos e lucros de outros investimentos, é distribuído aos empregados, provedores de capital, governo e reinvestido no grupo, pelas amortizações e depreciações, impostos diferidos, ganhos retidos, e outros. 
Figura 4 - DVA da Allied Electronics Corporation Limited - Altron - 2001

Value added is the measure of wealth the group has created in its operations by "adding value" to the cost of raw materials, products and services purchased. The statement below summarises the total wealth createdand showshowit was shared by employees and other parties who contributed to its creation. Also set out belowis the amount retainedand re-invested in the group for the replacement of assets and the further development of operations.

\begin{tabular}{|c|c|c|c|c|}
\hline & \multirow{2}{*}{$\begin{array}{c}2001 \\
\text { R million }\end{array}$} & \multicolumn{3}{|c|}{2000} \\
\hline & & $\%$ & $\mathrm{R}$ million & $\%$ \\
\hline Revenue & 8974 & & $\overline{6972}$ & \\
\hline \multirow[t]{2}{*}{ Suppliers of materials and services } & $(6530)$ & & (4 952) & \\
\hline & 2444 & & 2020 & \\
\hline Other income & 119 & & 163 & \\
\hline Total value added & 2563 & & 2183 & \\
\hline \multicolumn{5}{|l|}{ Applied as follows } \\
\hline To remunerate employees & 1656 & 64,6 & 1353 & 62,0 \\
\hline \multicolumn{5}{|l|}{$\begin{array}{l}\text { Salaries, wages, pensions and other } \\
\text { benefits }\end{array}$} \\
\hline To reward providers of capital & 249 & 9,7 & 190 & 8,7 \\
\hline Interest on loans & 6 & & 15 & \\
\hline Dividends to ordinary shareholders & 89 & & 81 & \\
\hline $\begin{array}{l}\text { Dividends to outside shareholders of } \\
\text { subsidiaries }\end{array}$ & 154 & & 94 & \\
\hline To the State & 157 & 6,1 & 189 & 8,6 \\
\hline Company tax & 130 & & 171 & \\
\hline Secondary tax on companies & 27 & & 18 & \\
\hline \multicolumn{5}{|l|}{ To replace assets } \\
\hline Depreciation & 160 & 6,3 & 126 & 5,8 \\
\hline To expand the group & 341 & 13,3 & 325 & 14,9 \\
\hline Net earnings retained - shareholders & 210 & & 174 & \\
\hline \multirow[t]{2}{*}{$\begin{array}{c}- \\
\text { outside shareholders }\end{array}$} & 131 & & 151 & \\
\hline & 2563 & 100,0 & 2183 & 100,0 \\
\hline
\end{tabular}

Fonte: Adaptado de Allied Electronics Corporation Limited Altron. Value added statement. Disponível em http://www.altron.co.za/valueadded.asp?subnav=yes\&menu=corp orate. Acesso em: 05/02/02. 
Figura 5 - DVA da Gold Fields Limited - 2001

For the year ended 30 June 2001

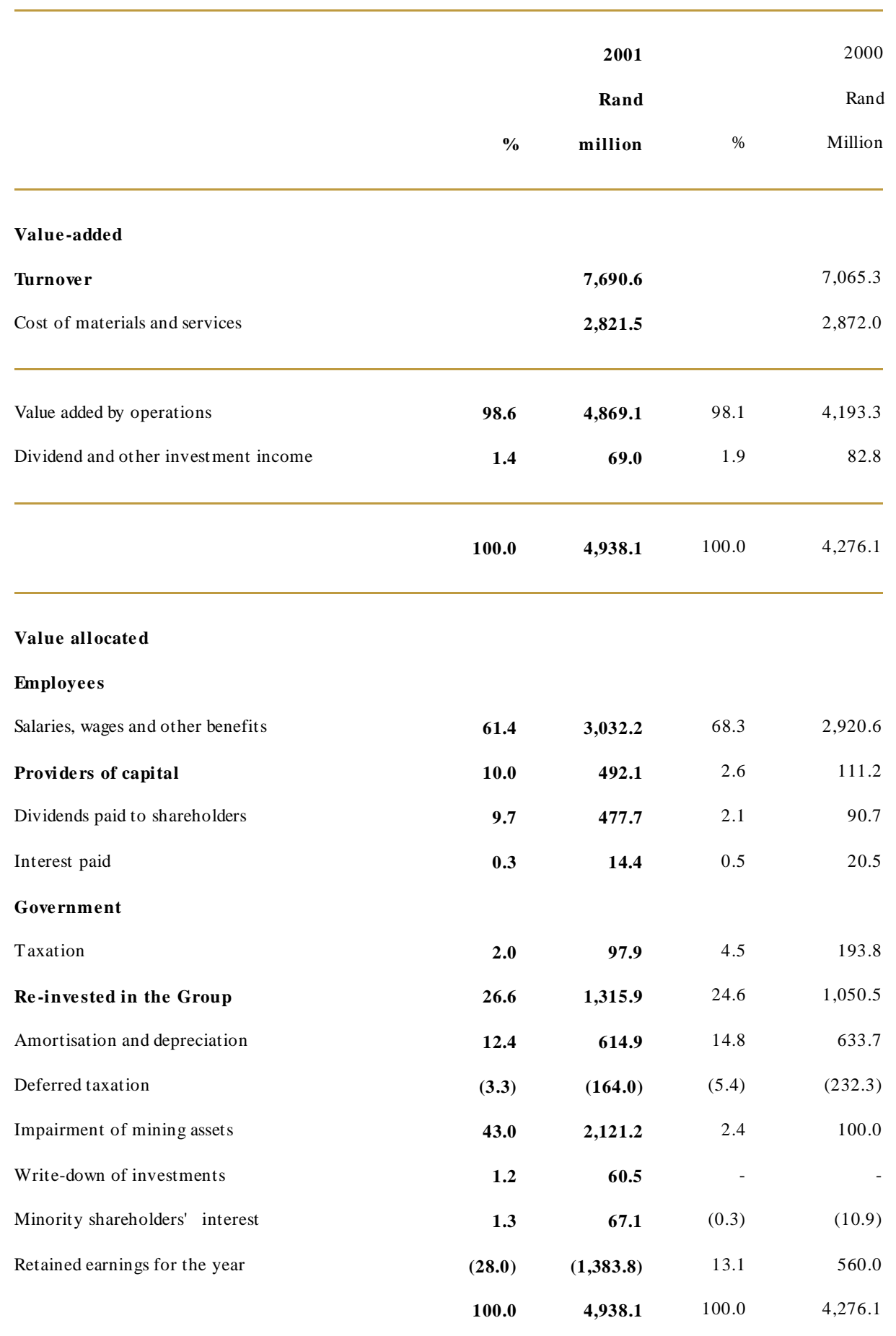

Fonte: Adaptado de Gold Fields Limited. Value-Added Statement. Disponível em http://www.goldfields.co.za/annual report. Acesso em: 21/03/02 
E, finalmente, na Figura 6, a BSES Limited, empresa indiana de geração, transmissão e distribuição de eletricidade, que fornece serviços de eletricidade para mais de 2,7 milhões de consumidores. A demonstração do valor adicionado é apresentada comparativamente aos anos de 1996 a 2001. Os valores estão expressos em rúpias indianas, moeda oficial do país. Consta do valor adicionado bruto formado pela diferença entre ganhos com vendas de energia, contratos e outros, menos seus custos. E, ainda do valor adicionado líquido, que é distribuído a pessoal, governo, juros, despesas extraordinárias, investidores e, ainda, retido pela empresa.

Figura 6 - DVA da BSES Limited - 1996-2001

\begin{tabular}{|l|c|c|c|c|c|}
\hline Particulars & $\mathbf{2 0 0 0 - 0 1}(\mathbf{P})$ & $\mathbf{1 9 9 9 - 2 0 0 0}$ & $\mathbf{1 9 9 8 - 9 9}$ & $\mathbf{1 9 9 7 - 9 8}$ & $\mathbf{1 9 9 6 - 9 7}$ \\
\hline Earnings from sale of Electricity Energy & $\mathbf{2 1 5 , 0 8 9 . 7 7}$ & 194786.97 & $175,976.64$ & $188,972.13$ & $177,206.84$ \\
\hline Income from EPC, Contracts and Computer & $\mathbf{5 3 , 6 4 2 . 3 7}$ & 39057.36 & $50,039.88$ & $10,908.36$ & $8,239.02$ \\
\hline Other Income & $\mathbf{7 5 7 8 . 3 2}$ & 9118.36 & $8,925.98$ & $6,851.12$ & $4,547.26$ \\
\hline Corporate Output & $\mathbf{2 7 6 , 3 1 0 . 4 6}$ & $\mathbf{2 4 2 9 6 2 . 6 9}$ & $\mathbf{2 3 4 , 9 4 2 . 5 0}$ & $\mathbf{2 0 6 , 7 3 1 . 6 1}$ & $\mathbf{1 8 9 , 9 9 3 . 1 2}$ \\
\hline Less : & & & & & \\
\hline Cost of Electricity Purchased & $\mathbf{1 0 0 , 5 3 6 . 0 8}$ & 70345.07 & $68,320.92$ & $78,058.50$ & $87,520.89$ \\
\hline Cost of Fuel & $\mathbf{3 9 , 3 5 5 . 9 6}$ & 41610.06 & $34,267.51$ & $37,830.49$ & $30,609.80$ \\
\hline Cost of Materials and other direct materials & $\mathbf{4 5 , 3 9 5 . 6 6}$ & 34664.68 & $43,489.94$ & $8,355.13$ & $6,008.14$ \\
\hline & $\mathbf{1 8 5 , 2 8 7 . 7 0}$ & $\mathbf{1 4 6 6 1 9 . 8 1}$ & $\mathbf{1 4 6 , 0 7 8 . 3 7}$ & $\mathbf{1 2 4 , 2 4 4 . 1 2}$ & $\mathbf{1 2 4 , 1 3 8 . 8 3}$ \\
\hline Gross Value Added & $\mathbf{9 1 , 0 2 2 . 7 6}$ & $\mathbf{9 6 3 4 2 . 8 8}$ & $\mathbf{8 8 , 8 6 4 . 1 3}$ & $\mathbf{8 2 , 4 8 7 . 4 9}$ & $\mathbf{6 5 , 8 5 4 . 2 9}$ \\
\hline Administrative \& Other Expenses & $\mathbf{2 1 , 2 4 1 . 4 3}$ & 21266.84 & $18,942.03$ & $19,977.45$ & $15,110.95$ \\
\hline Depreciation & $\mathbf{1 9 , 6 8 1 . 3 8}$ & 18347.08 & $17,139.41$ & $15,535.08$ & $13,145.77$ \\
\hline & $\mathbf{4 0 , 9 2 2 . 8 1}$ & $\mathbf{3 9 6 1 3 . 9 2}$ & $\mathbf{3 6 , 0 8 1 . 4 4}$ & $\mathbf{3 5 , 5 1 2 . 5 3}$ & $\mathbf{2 8 , 2 5 6 . 7 2}$ \\
\hline Net Value Added & $\mathbf{5 0 , 0 9 9 . 9 5}$ & $\mathbf{5 6 7 2 8 . 9 6}$ & $\mathbf{5 2 , 7 8 2 . 6 9}$ & $\mathbf{4 6 , 9 7 4 . 9 6}$ & $\mathbf{3 7 , 5 9 7 . 5 7}$ \\
\hline Allocation of net value added & & & & & \\
\hline To Personnel & $\mathbf{9 , 5 2 4 . 3 5}$ & 7619.28 & $6,291.85$ & $5,187.73$ & $4,478.85$ \\
\hline To Taxes & $\mathbf{2 , 9 0 3 . 8 1}$ & 9002.93 & $8,002.62$ & $3,501.62$ & 501.53 \\
\hline To Creditors (via interest) & $\mathbf{5 , 5 3 4 . 4 7}$ & 9424.20 & $11,463.66$ & $12,058.97$ & $11,287.34$ \\
\hline To Extraordinary Expenses/(Income) & $\mathbf{2 , 5 8 6 . 5 0}$ & 399.61 & 69.22 & $(81.40)$ & $1,380.48$ \\
\hline $\begin{array}{l}\text { To Investors (via dividend including dividend } \\
\text { tax) }\end{array}$ & $\mathbf{6 , 8 5 6 . 8 4}$ & 6811.52 & $6,205.29$ & $5,507.16$ & $5,121.92$ \\
\hline To Company (via retained earnings) & $\mathbf{2 2 , 6 9 3 . 9 8}$ & 23471.42 & $20,750.05$ & $20,800.88$ & $14,827.45$ \\
\hline Net Value Added & $\mathbf{5 0 , 0 9 9 . 9 5}$ & $\mathbf{5 6 7 2 8 . 9 6}$ & $\mathbf{5 2 , 7 8 2 . 6 9}$ & $\mathbf{4 6 , 9 7 4 . 9 6}$ & $\mathbf{3 7 , 5 9 7 . 5 7}$ \\
\hline
\end{tabular}




\subsubsection{A DVA no Brasil}

No Brasil, a lei societária que vigora atualmente - Lei 6.404 de 15 de dezembro de 1.976, e que dispõe sobre as sociedades por ações - não contempla a divulgação da demonstração do valor adicionado, conforme transcrição a seguir:

"Art. 176 - Ao fim de cada exercício social, a diretoria fará elaborar, com base na escrituração mercantil da companhia, as seguintes demonstrações financeiras, que deverão exprimir com clareza a situação do patrimônio da companhia e as mudanças ocorridas no exercício:

I - balanço patrimonial;

II - demonstração dos lucros e prejuízos acumulados;

III - demonstração do resultado do exercício; $e$

IV - demonstração das origens e aplicações de recursos."

No entanto, a partir das discussões sobre a responsabilidade social das empresas e sua prestação de contas para a sociedade, as empresas brasileiras passaram a sentir a importância do cálculo e da divulgação do valor adicionado e de sua distribuição. Seja por assumirem a responsabilidade social que lhes era embutida, seja por cobranças da própria sociedade, ou ainda como forma de marketing.

Fato é que se encontra na Câmara dos Deputados, o Projeto de Lei n. ${ }^{\circ}$ 3.741/2000, de autoria do Poder Executivo, que altera e revoga dispositivos da Lei 6.404/76 - a Lei das sociedades por ações. Dentre outras alterações previstas, o artigo 176 passará a vigorar com a seguinte redação:

"Art. 176 - Ao fim de cada exercício social, a diretoria da companhia fará elaborar, com base na escrituração mercantil, as seguintes demonstrações contábeis, que deverão exprimir com clareza a situação patrimonial e financeira e as mutações ocorridas no exercício:

II - demonstrações do patrimônio líquido;

IV - demonstrações dos fluxos de caixa; $e$

$V$ - demonstração do valor adicionado."

Além de incluir a DVA entre as demonstrações contábeis de elaboração obrigatória, o Projeto de Lei estende às sociedades de grande porte essa obrigatoriedade, mesmo quando não constituídas sob a forma de sociedades por ação. São consideradas de grande porte as sociedades ou conjunto delas - que façam parte de um mesmo grupo 
ou que estejam sob controle comum - que possuírem, no exercício social anterior, ativo acima de 120 milhões de reais ou receita bruta anual acima de 150 milhões de reais ${ }^{91}$.

Sendo assim, as sociedades por quotas de responsabilidade limitada, que são maioria e contam com legislação própria, o Decreto $\mathrm{n}^{\circ}$ 3.708, de 10 de janeiro de 1919, continuariam isentas da obrigatoriedade de publicação das demonstrações contábeis.

Mas já se encontra na Câmara dos Deputados, para apreciação do plenário, oriundo do Senado, o Projeto de Lei n. ${ }^{\circ}$ 2.813/2000, que dispõe sobre a criação da obrigatoriedade de publicação das demonstrações contábeis das sociedades por quotas de responsabilidade limitada, alterando o Decreto n. ${ }^{\circ} 3.708$, de 10/01/19, equiparando, assim, as empresas, em todas as suas obrigações para com a sociedade.

O Conselho Federal de Contabilidade - CFC, assim se pronunciou quanto ao Projeto de Lei:

'O CFC apóia o PL n $n^{\circ}$ 2.813/00 do Senado. A melhora de nossa economia é um item basilar para toda a sociedade. Só será possível atingir essa meta com a transparência nas informações básicas das empresas, em particular de seus atos contábeis. A obrigatoriedade da publicação desses informes, com base na escritura mercantil, servirá, não só para tornar diáfana a efetiva situação financeira da companhia, mas para incentivar os investimentos e o uso da poupança dos indivíduos que baseiam neles suas decisões econômicas. O CFC rejeita qualquer tipo de suprimento do PL ou sua alteração, já que qualquer mudança implicará no esvaziamento e desconfiguração do próprio $P L .,{ }^{92}$

A transcrição do Projeto de Lei é feita a seguir:

"Art. $1^{o}$ - As sociedades constituídas por quotas de responsabilidade limitada deverão, com base na escrituração mercantil da empresa, publicar as seguintes demonstrações financeiras, que, complementadas por notas explicativas deverão exprimir com clareza a posição patrimonial e financeira da sociedade e as mutações ocorridas no exercício:

I- balanço patrimonial;

II - demonstração dos lucros ou prejuízos acumulados;

\footnotetext{
${ }^{91}$ Conforme art. $2^{\circ}$ do Projeto de Lei 3.741/2000.

${ }^{92}$ CONSELHO FEDERAL DE CONTABILIDADE. Disponível em http://www.cfc.org.br/ .Acesso em 06 de fev. de 2002
} 
III - demonstração do resultado do exercício; e
$I V$ - demonstração das origens e aplicações de recursos.

Parágrafo único: o disposto no caput não se aplica às sociedades cuja receita bruta não ultrapasse o limite estabelecido para classificação como pequena empresa, nos termos da Lei $n^{\circ} 9.841$ de 5 de outubro de 1999." $93^{3}$

Cabe ressaltar que o avanço conseguido com o Projeto de Lei n. ${ }^{\circ} 3.741 / 2000$, a inclusão da DVA entre as demonstrações contábeis obrigatórias foi aqui totalmente esquecido. A realidade do país é feita de um número extremamente expressivo de sociedades por cotas de responsabilidade limitada que se manterão fora da obrigatoriedade de publicação da DVA, pois, como pode ser observado, essa demonstração não consta do projeto.

Nos meios acadêmicos, desde o ano de 1989, com a publicação do primeiro artigo sobre o assunto $^{94}$, o professor Eliseu Martins, da Faculdade de Economia, Administração e Contabilidade da Universidade de São Paulo - FEA/USP, vem incentivando as discussões e pesquisas sobre o cálculo e divulgação da geração e distribuição da riqueza das empresas por meio da DVA. Desde então, o número de empresas que publicam essa demonstração vem aumentando.

Conforme informações do próprio Martins ${ }^{95}$, a empresa Mappin Lojas de Departamentos S/A, controlada da companhia de capital aberto Casa Anglo Brasileira S/A, foi a primeira empresa brasileira a divulgar, referente ao ano de 1994, a DVA como nota explicativa de suas demonstrações contábeis, a nota de número 18. Até então, as demais empresas que vinham divulgando essa demonstração, o faziam dentro do relatório da administração, a exemplo do Banco Itaú.

\footnotetext{
${ }^{93}$ Considera-se empresa de pequeno porte conforme o art. $2^{\circ}$ da referida Lei, a pessoa jurídica e a firma individual que tiver receita bruta igual ou inferior a $\mathrm{R} \$ 1.2000 .000,00$.

${ }^{94}$ MARTINS, Eliseu. Uma nova demonstração contábil: a do valor adicionado. IOB informações objetivas. São Paulo: boletim TC 11/89. p. 4.

${ }^{95}$ MARTINS, Eliseu. Demonstração do valor adicionado - Alguns exemplos reais. IOB informações objetivas. São Paulo: boletim TC 31/97. p. 1.
} 
No ano de $1997^{96}$, os professores Ariovaldo dos Santos e L. Nelson de Carvalho, também da FEA/USP, responsáveis pela edição de Melhores e Maiores - MM - da Revista Exame, publicação respeitável nos meios empresariais e acadêmicos, que analisa e lista anualmente as 500 Melhores e Maiores empresas do ano, mediante critérios próprios e objetivos de domínio público, publicaram dois artigos intitulados "Balanço social, um indicador de excelência" e "DVA, uma forma de avaliar a criação de riqueza", destacando a grande importância das informações sociais e a utilidade da DVA.

A partir da edição de MM de 1998, dados relativos à DVA passaram a fazer parte desse critério de avaliação; por exemplo, o índice "valor adicionado por empregado" passou a constar do conjunto de índices utilizados para a escolha das Melhores e Maiores empresas do país, sob a égide da "excelência empresarial".

Para tanto, foi desenvolvido na Fundação Instituto de Pesquisas Contábeis, Atuariais e Financeiras - FIPECAFI, um modelo de DVA, para distribuição entre as empresas constantes do cadastro usado para a edição anual da MM, juntamente com as instruções de preenchimento. Esse modelo passou a ser usado como padrão por aquelas empresas que enviavam suas informações para participar do ranking da MM, e por muitas outras.

O modelo desenvolvido na FIPECAFI e suas instruções de preenchimento estão reproduzidos na Figura 7.

Os aspectos práticos, relacionados ao cálculo e modelo da DVA apresentado, serão discutidos no próximo capítulo.

\footnotetext{
${ }^{96}$ SANTOS, Ariovaldo dos. Demonstração contábil do valor adicionado- DVA- Um instrumento para medição da geração e distribuição de riqueza das empresas. Tese de Livre Docência - Faculdade de Economia e Contabilidade da Universidade de São Paulo. São Paulo: FEA/USP, 1999. p. 56-57
} 
Figura 7 - DVA modelo FIPECAFI

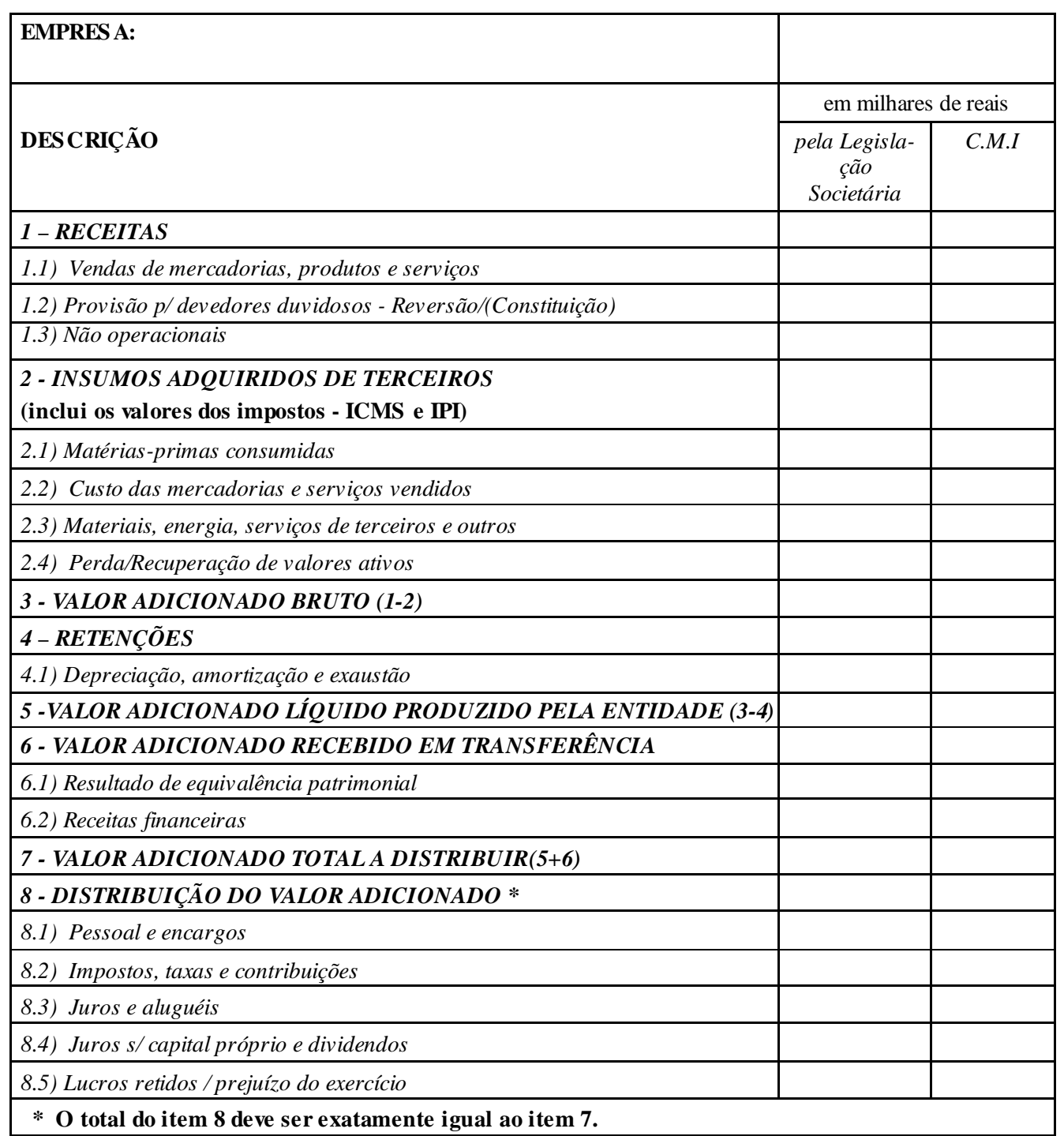

A DVA de verá ser referente ao exercício social da empresa. 


\section{Instruções para preenchimento}

As informações são extraídas da contabilidade e, portanto, deverão ter como base o princípio contábil do regime de competência de exercícios. Favor preencher com os dados da controladora.

1 - RECEITAS (soma dos itens 1.1 a 1.3)

1.1 - Vendas de mercadorias, produtos e serviços

Inclui os valores do ICMS e IPI incidentes sobre essas receitas, ou seja, corresponde à receita bruta ou faturamento bruto.

1.2 - Provisão para devedores duvidosos - Reversão/Constituição

Inclui os valores relativos à constituição/baixa de provisão para devedores duvidosos.

1.3 - Não operacionais

Inclui valores considerados fora das atividades principais da empresa, tais como: ganhos ou perdas na baixa de imobilizados, ganhos ou perdas na baixa de investimentos, etc.

2 - INSUMOS ADQUIRIDOS DE TERCEIROS (soma dos itens 2.1 a 2.4)

2.1 - Matérias-primas consumidas (incluídas no custo do produto vendido).

2.2 - Custos das mercadorias e serviços vendidos (não inclui gastos com pessoal próprio).

2.3 - Materiais, energia, serviços de terceiros e outros (inclui valores relativos às aquisições e pagamentos a terceiros).

Nos valores dos custos dos produtos e mercadorias vendidos, materiais, serviços, energia, etc. consumidos deverão ser considerados os impostos (ICMS e IPI) incluídos no momento das compras, recuperáveis ou não. 2.4 - Perda/Recuperação de valores ativos

Inclui valores relativos a valor de mercado de estoques e investimentos, etc. (se no período o valor líquido for positivo deverá ser somado).

3 - VALOR ADICIONADO BRUTO (diferença entre itens 1 e 2).

\section{4 - RETENÇÕES}

4.1 - Depreciação, amortização e exaustão

Deverá incluir a despesa contabilizada no período.

5 - VALOR ADICIONADO LÍQUIDO PRODUZIDO PELA ENTIDADE (diferença entre itens 3 e 4).

6 - VALOR ADICIONADO RECEBIDO EM TRANSFERÊNCIA (soma dos itens 6.1 e 6.2)

6.1 - Resultado de equivalência patrimonial (inclui os valores recebidos como dividendos relativos a investimentos avaliados ao custo). O resultado de equivalência poderá representar receita ou despesa; se despesa deverá ser informado entre parênteses.

6.2 - Receitas financeiras (incluir todas as receitas financeiras independentemente de sua origem).

7 - VALOR ADICIONADO TOTAL A DISTRIBUIR (soma dos itens 5 e 6 )

8 - DISTRIBUIÇÃO DO VALOR ADICIONADO (soma dos itens 8.1 a 8.5)

8.1 - Pessoal e encargos

Nesse item deverão ser incluídos os encargos com férias, 13ํㅗㄴ salário, FGTS, alimentação, transporte, etc., apropriados ao custo do produto ou resultado do período (não incluir encargos com o INSS - veja tratamento a ser dado no item seguinte).

8.2 - Impostos, taxas e contribuições

Além das contribuições devidas ao INSS, imposto de renda, contribuição social, todos os demais impostos, taxas e contribuições deverão ser incluídos neste item. Os valores relativos ao ICMS e IPI deverão ser considerados como os valores devidos ou já recolhidos aos cofres públicos, representando a diferença entre os impostos incidentes sobre as vendas e os valores considerados dentro do item 2 - Insumos adquiridos de terceiros.

\section{3 - Juros e aluguéis}

Devem ser consideradas as despesas financeiras e as de juros relativas a quaisquer tipos de empréstimos e financiamentos junto à instituições financeiras, empresas do grupo ou outras e os aluguéis (incluindo-se as despesas com leasing) pagos ou creditados a terceiros.

8.4 - Juros sobre o capital próprio e dividendos

Inclui os valores pagos ou creditados aos acionistas. Os juros sobre o capital próprio contabilizados como reserva deverão constar do item "lucros retidos".

8.5 - Lucros retidos/prejuízo do exercício

Devem ser incluídos os lucros do período destinados às reservas de lucros e eventuais parcelas ainda sem destinação específica.

Fonte: FIPECAFI: Fundação Instituto de Pesquisas Contábeis, Atuariais e Financeiras - FEA/USP. 


\subsection{Renda}

Apresenta-se, neste tópico uma brevíssima idéia dos conceitos econômicos sobre renda, sua distribuição e concentração. Assim sendo, não entrou-se no mérito das características de quais seriam os melhores indicadores existentes. Preocupou-se apenas em expressar a grandeza das diferenças nos indicadores de concentração e distribuição de renda que refletissem a abrangência local, regional e internacional para evidenciar as diferenças na distribuição e concentração de renda.

Segundo Rizzieri" ${ }^{97}$, a renda "mede o fluxo de pagamento dos fatores de produção, isto é, salário, juros, lucro e aluguel... ." No mercado, esses fatores são remunerados de acordo com a lei da oferta e da procura, determinando que algumas pessoas recebam mais renda que outras.

Conforme Seldon e Pennance ${ }^{98}$, renda, "de um modo geral, é o que é recebido pelos indivíduos, pelas companhias ou pelos governos, em um determinado período, e derivado dos ganhos individuais ou da propriedade de fatores de produção." Assim, para obter uma renda, os homens vendem as riquezas de que dispõem: os assalariados oferecem sua força de trabalho, os capitalistas os serviços do seu dinheiro, e os proprietários os serviços de sua terra.

Hicks apud Lucas $^{99}$ conceitua renda ressaltando a característica do excedente, que é uma visão econômica: “aquilo que é possível consumir sem se empobrecer”, e Brochier ${ }^{100}$, também citado por Lucas, acrescentou o caráter da poupança ao seu conceito: "o máximo que pode ser consumido economizando -se para o futuro possibilidades iguais de consumo."

\footnotetext{
${ }^{97}$ RIZZIERI, Juarez Alexandre Baldini. Teoria da determinação da renda e produto nacional. In: PINHO, Diva Benevides, VASCONCELlOS, Marco A. Sandoval de (coord.). Manual de economia. op. cit. p. 309

${ }^{98}$ SELDON, Arthur, PENNANCE, F. G.. Dicionário de economia. Tradução Nelson Vicenzi. 2. ed. Rio de Janeiro: Bloch, 1975. p.401-402

${ }^{99}$ HICKS, J. H. Value and capital. 2. ed. Oxford: Claredon Press, 1946. p. 172 In: LUCAS, Fábio. Introdução ao estudo da repartição de renda. Belo Horizonte: Faculdade de ciências econômicas da Universidade de Minas Gerais, 1959. p. 25

${ }^{100}$ BROCHIER, Hubert. Finances publiques et redistribution des revenues. Paris: Armand Colin, 1950. p. 10. In: LUCAS, Fábio. op. cit. p. 25
} 
A distribuição de rendas e sua concentração, ou distribuição desigual, tem como conseqüência a divisão da sociedade numa hierarquia de classes que traz prestígio e poder aos que estão no topo, e que tem permeado a maioria das lutas sociais ocorridas ao longo da história.

\subsubsection{Distribuição de renda}

O tema distribuição, ou repartição de renda, está necessariamente ligado aos grandes assuntos sócio-econômicos de nosso tempo: bem-estar, justiça, paz social e responsabilidade social. Tradicionalmente, ele é estudado sob o ponto de vista da distribuição funcional, isto é, da repartição da renda segundo os fatores de produção: terra, capital e trabalho, realizada por meio do pagamento de salários, juros, lucros e renda da terra ${ }^{101}$.

Conforme Lucas ${ }^{102}$, a maneira pela qual o montante dos bens e serviços produzidos pela coletividade é distribuído entre os indivíduos é que indica a distribuição da renda, e só há a repartição da renda porque a produção é coletiva, pois, se cada indivíduo produzisse o bastante para atender às suas necessidades, não existiria o problema da repartição, já que cada qual estaria consumindo apenas o produto do seu trabalho.

A distribuição desigual, ou diferenciada, da renda de um país ou região pelas diversas camadas sociais, é denominada de concentração de renda, existindo diversas teorias que a justificam. Dentre elas, a do capital humano, que explica a concentração de renda como reflexo dos diversos níveis de treinamento e escolaridade do indivíduo (o que necessariamente não é verdade, senão professores não ganhariam tão pouco); a matemática ou probabilística, que criou um modelo explicativo, segundo o qual a repartição de renda se alteraria influenciada por "choques aleatórios", que aumentariam ou diminuiriam a renda dos indivíduos; e a corrente

\footnotetext{
${ }^{101}$ SANDRONI, Paulo (Org.). Novíssimo dicionário de economia. 6. ed. São Paulo: Best Seller, 2001. p. 521 ${ }^{102}$ LUCAS, Fábio. Introdução ao estudo da repartição de renda. Belo Horizonte: Faculdade de ciências econômicas da Universidade de Minas Gerais, 1959. p. 15
} 
institucionalista, que define como determinantes da distribuição de renda as leis sobre herança, a força relativa dos sindicatos, e o papel do governo na fixação dos salários ${ }^{103}$.

Bouvier-Ajam apud Lucas ${ }^{104}$, listou, em 1948, nove causas da desigualdade e consequente concentração de renda, que englobam as três visões teóricas retro apresentadas:

'Causas da desigualdade das rendas:

1. as desigualdades de fortuna (heranças, legados, etc.);

2. as desigualdades físicas e intelectuais (porque geram desiguais aptidões para o trabalho e, conseqüentemente, diferentes remunerações);

3. as próprias desigualdades sociais (os filhos-famílias encontram mais facilmente uma boa colocação do que o homem saído do povo);

4. as variações das condições dos mercados (que tornam, seja pelo jogo da oferta e da procura, seja pelas restrições ou subvenções legais, seja pelas coalizões de interesse, um setor industrial ou comercial mais vantajoso do que outro);

5. os progressos técnicos supervenientes numa indústria (tornando-a repentinamente mais rentável) e as variações nas colheitas;

6. a concessão mais ou menos fácil de crédito;

7. as medidas fiscais, duaneiras e políticas;

8. o jogo da especulação;

9. a sorte ou o acaso (descobertas, invenções, ganhos de jogo)."

Wonnacott e Wonnacott ${ }^{105}$, também abordaram as razões pelas quais algumas pessoas recebem mais renda do que outras. Uma delas é decorrente das forças do mercado. A renda elevada de um profissional decorre do retorno pelo capital humano - uma compensação pelos anos em que sua renda foi postergada e pelos difíceis estudos para obtenção do diploma e de qualificação posteriores a ele (o que necessariamente não é verdade em todos os casos). Poderia, ainda, ser fruto do talento inato ou "dom" atribuídos a este profissional ou a outros que têm renda elevada, como alguns atletas ou artistas. As diferenças de renda também surgiriam devido ao estoque de riqueza; possuidores de títulos, ações, ou outros tipos de propriedade, recebem renda a partir delas, ou o fato das pessoas ocuparem uma

\footnotetext{
${ }^{103}$ SANDRONI, Paulo (Org.). Novíssimo dicionário de economia. 6. ed. São Paulo: Best Seller, 2001. p. 521 ${ }^{104}$ BOUVIER-AJAM, Maurice. Manuel d’economie politique. Paris: Arthur Rousseau, 1948. 2 Vols. p. 206207, Vol. 2, In: Lucas, Fábio. op. cit. p.37-38

${ }^{105}$ WONNACOTT, P., WONNACOTT, R. Introdução à economia. Tradução Nuno Renan L. F. Pinto et al. São Paulo: McGraw-Hill do Brasil, 1985. p. 505-506
} 
posição monopolista, em relação à oferta de trabalho, também seria responsável pelo aumento nas suas rendas.

Entretanto, existem razões para as diferenças observadas nas rendas, que não estão relacionadas às forças econômicas do mercado. Por exemplo, um profissional, por uma decisão pessoal, pode optar por sacrificar parte de sua renda em favor de seu lazer ${ }^{106}$, e um outro teria renda maior pelo fato de acertar na loteria (pura 'sorte").

Essa mesma idéia é defendida por Mankiw ${ }^{107}$, quando afirma: 'Os ganhos de uma pessoa dependem da oferta e da demanda por seu trabalho, que por sua vez dependem do talento natural, do capital humano, de diferenciais compensatórios, de discriminação e assim por diante.”

A diferença é que sua abordagem se resume à renda proveniente do trabalho, e todas as outras razões relacionadas à repartição de renda, são conseqüência direta da oferta e procura por ele. Continua afirmando que, de toda a renda da economia americana, três quartos são provenientes de ganhos do trabalho. Portanto, os mesmos fatores que determinam a renda proveniente do trabalho são também responsáveis por determinar como a renda total da economia se distribui entre os diversos membros da sociedade, ou seja, determinando quem é pobre ou rico. Para Lucas ${ }^{108}$, 'Uma sociedade é pobre ou rica, segundo é mais ou menos capaz de obrigar a natureza a fornecer o que é mister para a satisfação das necessidades humanas. A riqueza e a pobreza não exprimem senão a capacidade de um determinado grupo em satisfazer suas necessidades.” Com base no enfoque de Mankiw, apreende-se que a forma socialmente desejada de satisfazer essas necessidades, evitando a pobreza, seria obtida por meio dos rendimentos do trabalho.

\footnotetext{
${ }^{106}$ Segundo tese desses mesmos autores, a pessoa que diminui o trabalho em prol do lazer, está recebendo parte da sua renda em forma desse lazer, em lugar do dinheiro, ou seja, o lazer alcançado faria parte da renda.

${ }^{107}$ MANKIW, N. Gregory. Introdução à economia: princípios de micro e macroeconomia. Tradução Maria José Cyhlar Monteiro. 2. ed. Rio de Janeiro: Campus, 2001. p. 437

${ }^{108}$ op. cit. p. 23
} 


\subsubsection{Concentração de renda}

Conforme ficou ressaltado, a distribuição desigual da renda entre os indivíduos é explicada por várias teorias. Entretanto, quanto há de desigualdade nessa distribuição?

Várias são as medidas tradicionais da desigualdade de renda. Dentre elas, o coeficiente, ou índice, de Gini, que mede o grau de concentração da renda de uma dada localidade, região ou sociedade, e cujo valor varia de zero (perfeita igualdade) até um (desigualdade máxima) ${ }^{109}$; o índice de Theil, que é um indicador do nível de desigualdade na distribuição de renda, estando padronizado para variar de zero a um, e onde quanto mais próximo de um, maior a desigualdade ${ }^{110}$; a razão entre a renda média dos mais ricos e a dos mais pobres, ressaltando que quanto menor for a razão entre essas rendas médias mais equânime será a estrutura distributiva, com os mais ricos retendo uma renda média de valor relativamente próxima à dos pobres ${ }^{111}$. Uma outra medida comum de distribuição de renda é a taxa de pobreza, ou linha de pobreza, que se refere à renda mínima necessária para adquirir o valor de uma cesta básica de alimentos com quantidades energéticas mínimas ou recomendadas, e de arcar com todas as outras despesas não alimentares, como vestuário, moradia, transportes, etc. Esse valor é normalmente medido em termos de salários mínimos, que deveria, pelo menos em tese, suprir as necessidades básicas ou, de acordo com o Banco Mundial, corresponde a um dólar por dia. Á renda mínima necessária para adquirir apenas a cesta básica de alimentos, dá-se o nome de linha de indulgência ${ }^{112}$.

\footnotetext{
109 IBGE. Indicadores sociais mínimos. Disponível em http://www1.ibge.gov.br/ibge/estatistica/populacao/condicaodevida/indicadoresminimos/conceitos.shtm. Acesso em: $11 / 03 / 02$

110 IPARDES. Anuário estatístico do Estado do Paraná 2001. Paraná: 2001. Disponível em http://www.ipardes.gov.br/anuario2001 glossario.html .Acesso em :13/02/02.

111 BARROS, Ricardo Paes. HENRIQUES, Ricardo. MENDONÇA, Rosane. A estabilidade inaceitável: desigualdade e pobreza no Brasil. Rio de Janeiro: IPEA, jun. 2001 p. 12. (Texto para discussão $\mathrm{n}^{\circ} 800$ ). Disponível em http://ipea.gov.br/pub/td 2001/td0800.pdf. Acesso em: 11/03/02

112 DEL GROSSI, Mauro Eduardo. SILVA, José Graziano. TAKAGI, Maya. Evolução da pobreza no Brasil, 1995/99. Campinas: UNICAMP, n. 104, nov. 2001 p.2. Disponível em http://www.eco.unicamp.br/publicacoes/textos/dowload/texto104.pdf. Acesso em: 11/03/02
} 
A desigualdade de renda apresentada por alguns países não é desejável pela sociedade, ou pelo menos pela parte que aufere menor rendimento. Uma das formas para a redução da desigualdade na renda de uma nação é a cobrança de tributos. Conforme Wonnacott e Wonnacott ${ }^{113}$, "A sociedade requer a redução da desigualdade através dos impostos, que devem se concentrar mais pesadamente sobre os ricos, e através dos gastos governamentais, que devem se concentrar mais sobre os pobres." Resta saber em que grau isso é feito hoje por meio dos instrumentos de política econômica e social, aplicados pelos governos, no sentido de desconcentrar a renda.

Mas que distribuição de renda seria razoável, aceitável e justa? Essa discussão passa pelo entendimento de Wonnacott e Wonnacott ${ }^{114}$ :

'Essa é uma questão ética sobre a qual as pessoas não se mostram unânimes. Algumas acreditam que equidade é igualdade, que deveria ser paga a mesma renda para todos. Por outro lado, alguns acreditam que a equidade não é igualdade, pois, por exemplo, o indivíduo que trabalha mais ou de modo mais árduo deveria efetivamente receber mais."

As questões que se apresentam são várias. Qual a meta de justiça desejada para a distribuição de renda? Aquela que resulta do livre jogo das forças do mercado? Talvez, mas nem sempre o livre mercado realiza um trabalho satisfatório de distribuição de renda, pois sua preocupação maior é com conceitos de eficiência e maximização, o que não quer dizer equidade. A igualdade completa na renda dos cidadãos é justa? Aquele que sacrifica seus momentos de lazer preciosos por trabalho deveria ser compensado? Ou não é apenas o trabalho em si que deve ser recompensado, e sim a dificuldade que ele impõe ao indivíduo? A natureza do trabalho deve ser observada? E aquele que gasta seu tempo acumulando capital humano para obter um aumento de renda amanhã? E ainda, é injusto que alguém que sacrifique o consumo presente, poupando em benefício de um consumo maior amanhã, conte com uma renda maior? O ideal seria encontrar um ponto ótimo entre o intervalo que separa todas essas questões.

113 op. cit. p. 509
114 op. cit. p. 511 


\subsubsection{Distribuição de renda no Brasil}

O tema distribuição de renda ganhou importância no Brasil, quando da divulgação de dados do Censo de 1970 que comparados com os dados do Censo de 1960, mostraram a repartição de renda se tornando mais regressiva ao longo da década, comprovando que o desenvolvimento da economia beneficiava uma minoria, em detrimento da grande maioria da população ${ }^{115}$.

A distribuição de renda no Brasil continua crivada de diferenças. Essa afirmativa é comprovada pela Tabela 1, que mostra a evolução temporal da desigualdade da renda, de acordo com quatro medidas, de 1977 a 1999.

\section{Tabela 1 - Evolução Temporal dos Indicadores de Desigualdade da Renda}

\begin{tabular}{|c|c|c|c|c|}
\hline Ano & $\begin{array}{l}\text { Coeficiente } \\
\text { de Gini }\end{array}$ & $\begin{array}{l}\text { Índice de } \\
\text { Theil }\end{array}$ & $\begin{array}{l}\text { Razão entre a Renda Média dos } 20 \% \\
\text { mais Ricos e a dos } 20 \% \text { mais Pobres }\end{array}$ & $\begin{array}{l}\text { Razão entre a Renda Média dos } 10 \% \\
\text { mais Ricos e a dos } 40 \% \text { mais Pobres }\end{array}$ \\
\hline 1977 & 0,62 & 0,91 & 27,50 & 26,80 \\
\hline 1978 & 0,60 & 0,74 & 31,30 & 25,00 \\
\hline 1979 & 0,60 & 0,74 & 32,90 & 25,20 \\
\hline 1981 & 0,59 & 0,69 & 24,00 & 21,80 \\
\hline 1982 & 0,59 & 0,71 & 25,60 & 23,00 \\
\hline 1983 & 0,60 & 0,73 & 25,70 & 23,50 \\
\hline 1984 & 0,59 & 0,71 & 23,60 & 22,40 \\
\hline 1985 & 0,60 & 0,76 & 25,50 & 23,60 \\
\hline 1986 & 0,59 & 0,72 & 24,00 & 22,10 \\
\hline 1987 & 0,60 & 0,75 & 27,60 & 24,40 \\
\hline 1988 & 0,62 & 0,78 & 30,90 & 27,20 \\
\hline 1989 & 0,64 & 0,89 & 34,30 & 30,40 \\
\hline 1990 & 0,62 & 0,78 & 31,20 & 26,90 \\
\hline 1992 & 0,58 & 0,70 & 26,70 & 21,80 \\
\hline 1993 & 0,60 & 0,77 & 28,80 & 24,50 \\
\hline 1995 & 0,60 & 0,73 & 28,00 & 24,10 \\
\hline 1996 & 0,60 & 0,73 & 29,80 & 24,60 \\
\hline 1997 & 0,60 & 0,74 & 29,20 & 24,50 \\
\hline 1998 & 0,60 & 0,74 & 28,60 & 24,20 \\
\hline 1999 & 0,60 & 0,72 & 27,20 & 23,30 \\
\hline
\end{tabular}

Fonte: Adaptado de BARROS, Ricardo Paes. HENRIQUES, Ricardo. MENDONÇA, Rosane. A estabilidade inaceitável: desigualdade e pobreza no Brasil. Rio de Janeiro: IPEA, jun. 2001 p. 16. (Texto para discussão ${ }^{\circ}$ 800). Disponível em http://ipea.gov.br/pub/td_2001/td0800.pdf. Acesso em: 11/03/02.

\footnotetext{
${ }^{115}$ SINGER, Paul. Dominação e desigualdade: estrutura de classes e repartição de renda no Brasil. Rio de Janeiro: Paz e Terra, 1981. p. 149.
} 
Ao longo do período analisado, na Tabela 1, o grau de desigualdade é bastante estável, se mantendo alto sem tendência ao declínio. Um crescimento acelerado na desigualdade é verificado entre 1988 e 1989, onde o coeficiente de Gini chega a 0,64, o índice de Theil a 0,89 , os $20 \%$ mais ricos recebem uma renda média cerca de 35 vezes a dos $20 \%$ mais pobres, e os $10 \%$ mais ricos recebem uma renda cerca de 30 vezes a dos $40 \%$ mais pobres. O restante do período analisado mostra um cenário da concentração de renda em que o coeficiente de Gini se mantém no patamar de 0,60, os indivíduos que correspondem à parcela dos $20 \%$ mais ricos se apropriam de uma renda média entre 24 e 35 vezes superior aos $20 \%$ mais pobres e os $10 \%$ mais ricos, por sua vez, dispõem de uma renda entre 22 e 31 vezes maior do que a renda obtida pelos $40 \%$ mais pobres da população.

A percentagem da renda apropriada pelas diversas classes de pessoas está demonstrada na Tabela 2.

Tabela 2 - Evolução Temporal da Desigualdade da Renda

\begin{tabular}{lcccccc}
\hline \multicolumn{7}{c}{ Percentagem da Renda Apropriada pelas Pessoas } \\
Ano & 2,40 & 7,70 & 11,70 & 66,60 & 51,60 & 18,50 \\
\cline { 2 - 6 } & 2,10 & 7,60 & 12,00 & 64,10 & 47,70 & 13,60 \\
1977 & Pobres & $\begin{array}{c}40 \% \text { mais } \\
\text { Pobres }\end{array}$ & $\begin{array}{c}50 \% \text { mais } \\
\text { Pobres }\end{array}$ & $\begin{array}{c}20 \% \text { mais } \\
\text { Ricos }\end{array}$ & $\begin{array}{c}10 \% \text { mais } \\
\text { Ricos }\end{array}$ & $\begin{array}{c}\% \text { mais } \\
\text { Rico }\end{array}$ \\
1978 & 1,90 & 7,50 & 11,90 & 64,20 & 47,60 & 13,40 \\
1979 & 2,60 & 8,60 & 13,00 & 63,10 & 46,70 & 12,70 \\
1982 & 2,50 & 8,20 & 12,60 & 63,70 & 47,30 & 13,10 \\
1983 & 2,50 & 8,10 & 12,40 & 64,40 & 47,70 & 13,50 \\
1984 & 2,70 & 8,50 & 12,80 & 63,80 & 47,60 & 13,20 \\
1985 & 2,50 & 8,20 & 12,40 & 64,40 & 48,20 & 14,20 \\
1986 & 2,60 & 8,50 & 12,90 & 63,40 & 47,20 & 13,80 \\
1987 & 2,30 & 7,90 & 12,10 & 64,30 & 48,00 & 14,10 \\
1988 & 2,10 & 7,30 & 11,30 & 66,00 & 49,70 & 14,40 \\
1989 & 2,00 & 6,80 & 10,50 & 67,80 & 51,70 & 16,40 \\
1990 & 2,10 & 7,30 & 11,30 & 65,60 & 49,10 & 14,20 \\
1992 & 2,30 & 8,40 & 13,10 & 62,10 & 45,80 & 13,20 \\
1993 & 2,20 & 7,90 & 12,30 & 64,50 & 48,60 & 15,00 \\
1995 & 2,30 & 8,00 & 12,30 & 64,20 & 47,90 & 13,90 \\
1996 & 2,10 & 7,70 & 12,10 & 64,10 & 47,60 & 13,50 \\
1997 & 2,20 & 7,80 & 12,10 & 64,20 & 47,70 & 13,80 \\
1998 & 2,20 & 7,90 & 12,20 & 64,20 & 47,90 & 13,90 \\
1999 & 2,30 & 8,10 & 12,60 & 63,80 & 47,40 & 13,30 \\
\hline & & & & & & \\
\hline
\end{tabular}

Fonte: Adaptado de BARROS, Ricardo Paes. HENRIQUES, Ricardo. MENDONÇA, Rosane. A estabilidade inaceitável: desigualdade e pobreza no Brasil. Rio de Janeiro: IPEA, jun. 2001 p. 17. (Texto para discussão ${ }^{\circ}$ 800). Disponível em http://ipea.gov.br/pub/td_2001/td0800.pdf. Acesso em: 11/03/02. 
Como destaque da Tabela 2, vê-se que os indivíduos que se encontram entre os $10 \%$ mais ricos da população se apropriam de cerca de $50 \%$ do total da renda, enquanto os que se encontram entre os 50\% mais pobres detêm, ao longo do período analisado, no máximo $13 \%$. O conjunto dos $20 \%$ mais pobres da população fica com cerca de $2,5 \%$ da renda total, enquanto os $1 \%$ mais ricos se apropriam de uma renda superior àquela apropriada por metade da população brasileira.

A distribuição de renda média familiar entre os $50 \%$ mais pobres e os $1 \%$ mais ricos, segundo as regiões e Unidades da Federação, nos períodos de 1992 e 1999, pode ser observada na Tabela 3.

Observa-se, na Tabela 3, que no ano de 1992 a região do país onde os 50\% mais pobres da população se apropriam da menor parcela da renda - $12,9 \%$ da renda total é a região nordeste (a média nacional nesse período é de 14,0\%); e onde os $1 \%$ mais ricos ficam com a maior parcela - 17,2\% - é a região centro-oeste (a média nacional é 13,1\%). Em 1999, a posição se inverteu, com a região centro-oeste possuindo os 50\% mais pobres com menor renda - $13,7 \%$ da renda total - e a região nordeste com a maior concentração de renda nos $1 \%$ mais ricos - 16\% (as médias nacionais se mantiveram em $14,0 \%$ e $13,1 \%$, respectivamente). No início da década, o estado brasileiro com a maior concentração de renda nos $1 \%$ mais ricos da população $21,9 \%$ - é Goiás, e a Paraíba é o estado onde os 50\% mais pobres ficam com a menor parcela da renda total - $10,1 \%$. Ao final da década, a posição de maior concentrador de renda nos $1 \%$ mais ricos é do Ceará - 17,4\% - e de menor concentrador nos 50\% mais pobres é o Distrito Federal - 10,9\%.

Dados sobre a renda média familiar per capita, dos $10 \%$ mais pobres, $40 \%$ mais pobres e $10 \%$ mais ricos, em reais e em salários mínimos, também por regiões e Unidades da Federação, para os anos de 1992 e 1999, estão na Tabela 4. 
Tabela 3- Distribuição do rendimento, por Regiões e Unidades da Federação, dos $50 \%$ mais pobres e dos $1 \%$ mais ricos, em relação ao rendimento total

\begin{tabular}{|c|c|c|c|c|}
\hline \multirow{2}{*}{$\begin{array}{l}\text { Grandes Regiões e } \\
\text { Unidades da } \\
\text { Federação }\end{array}$} & \multicolumn{2}{|c|}{ Rendimento (\%) } & \multicolumn{2}{|c|}{ Rendimento (\%) } \\
\hline & $50 \%$ mais pobres & $1 \%$ mais ricos & $50 \%$ mais pobres & $1 \%$ mais ricos \\
\hline & \multicolumn{2}{|c|}{1992} & \multicolumn{2}{|c|}{1999} \\
\hline Brasil & 14,0 & 13,1 & 14,0 & 13,1 \\
\hline Norte & 16,0 & 10,2 & 15,1 & 12,0 \\
\hline Rondônia & 16,2 & 9,9 & 14,5 & 10,2 \\
\hline Acre & 14,1 & 7,5 & 13,0 & 11,6 \\
\hline Amazonas & 17,5 & 8,1 & 18,0 & 9,9 \\
\hline Roraima & 18,1 & 8,6 & 15,3 & 6,3 \\
\hline Pará & 15,4 & 11,6 & 15,2 & 13,6 \\
\hline Amapá & 19,8 & 6,6 & 16,3 & 7,0 \\
\hline Tocantins & 13,1 & 17,9 & 15,4 & 15,0 \\
\hline Nordeste & 12,9 & 14,7 & 15,7 & 16,0 \\
\hline Maranhão & 13,0 & 12,0 & 16,4 & 15,8 \\
\hline Piauí & 10,9 & 17,5 & 16,2 & 16,9 \\
\hline Ceará & 12,1 & 15,4 & 15,7 & 17,4 \\
\hline Rio Grande do Norte & 12,0 & 14,7 & 15,4 & 14,8 \\
\hline Paraíba & 10,1 & 13,2 & 12,4 & 15,4 \\
\hline Pernambuco & 13,5 & 14,3 & 15,3 & 16,2 \\
\hline Alagoas & 14,1 & 13,6 & 17,5 & 14,5 \\
\hline Sergipe & 14,9 & 12,7 & 13,9 & 15,1 \\
\hline Bahia & 14,5 & 15,0 & 16,8 & 15,2 \\
\hline Sudeste & 15,4 & 11,6 & 15,1 & 11,7 \\
\hline Minas Gerais & 15,4 & 14,3 & 15,3 & 13,6 \\
\hline Espírito Santo & 15,9 & 10,6 & 14,9 & 11,5 \\
\hline Rio de Janeiro & 15,9 & 12,2 & 15,3 & 12,1 \\
\hline São Paulo & 16,4 & 10,5 & 16,2 & 10,7 \\
\hline Sul & 15,8 & 13,8 & 15,1 & 12,6 \\
\hline Paraná & 16,0 & 11,9 & 14,3 & 13,5 \\
\hline Santa Catarina & 16,7 & 16,9 & 17,2 & 11,9 \\
\hline Rio Grande do Sul & 15,7 & 13,4 & 14,8 & 12,1 \\
\hline Centro-Oeste & 14,5 & 17,2 & 13,7 & 14,3 \\
\hline Mato Grosso do Sul & 15,4 & 16,1 & 15,3 & 12,8 \\
\hline Mato Grosso & 18,2 & 11,3 & 16,1 & 13,3 \\
\hline Goiás & 14,2 & 21,9 & 15,4 & 14,5 \\
\hline Distrito Federal & 13,6 & 12,0 & 10,9 & 12,3 \\
\hline
\end{tabular}

Fonte: Adaptado de IBGE. Síntese de Indicadores Sociais. Disponível em http://www2.ibge.gov.br/ibge/ftp/ftp.php?dir=/Indicadores Sociais/Síntese de Indicadores Sociais 2000. Acesso em: 11/03/02 
Tabela 4 - Renda média familiar per capita, em reais e em salários mínimos, por Grandes Regiões e Unidades da Federação - 1992/1999.

\begin{tabular}{|c|c|c|c|c|c|c|c|c|}
\hline \multirow{3}{*}{$\begin{array}{c}\text { Grandes Regiões e } \\
\text { Unidades da } \\
\text { Federação }\end{array}$} & \multicolumn{6}{|c|}{ Renda média familiar per capita } & \multirow{2}{*}{\multicolumn{2}{|c|}{$\begin{array}{l}\text { Relação entre } \\
\text { rendas médias }\end{array}$}} \\
\hline & \multicolumn{3}{|c|}{ Em R\$ } & \multicolumn{3}{|c|}{ Em salário mínimo } & & \\
\hline & $\begin{array}{c}10 \% \\
\text { mais } \\
\text { pobres }\end{array}$ & $\begin{array}{c}40 \% \\
\text { mais } \\
\text { pobres }\end{array}$ & $\begin{array}{l}10 \% \text { mais } \\
\text { ricos }\end{array}$ & $\begin{array}{l}10 \% \\
\text { mais } \\
\text { pobres } \\
\text { (A) }\end{array}$ & $\begin{array}{l}40 \% \\
\text { mais } \\
\text { pobres } \\
\text { (B) }\end{array}$ & $\begin{array}{l}10 \% \\
\text { mais } \\
\text { ricos } \\
(\mathrm{C})\end{array}$ & $\mathrm{C} / \mathrm{A}$ & $\mathrm{C} / \mathrm{B}$ \\
\hline \multicolumn{9}{|c|}{1992} \\
\hline Brasil & 18,42 & $\mathbf{5 0 , 5 4}$ & $1.053,09$ & 0,14 & $\mathbf{0 , 3 7}$ & $\mathbf{7 , 7 4}$ & 57,18 & 20,84 \\
\hline Norte & 17,60 & 42,66 & 790,14 & $\mathbf{0 , 1 3}$ & 0,31 & $\mathbf{5 , 8 1}$ & 44,90 & 18,52 \\
\hline Rondônia & 24,41 & 53,01 & 904,08 & 0,18 & 0,39 & 6,65 & 37,03 & 17,06 \\
\hline Acre & 15,85 & 50,86 & 937,64 & 0,12 & 0,37 & 6,90 & 59,14 & 18,44 \\
\hline Amazonas & 17,15 & 43,20 & 792,95 & 0,13 & 0,32 & 5,83 & 46,24 & 18,35 \\
\hline Roraima & 32,27 & 70,72 & $1.326,52$ & 0,24 & 0,52 & 9,75 & 41,11 & 18,76 \\
\hline Pará & 18,53 & 40,70 & 743,21 & 0,14 & 0,30 & 5,46 & 40,11 & 18,26 \\
\hline Amapá & 21,75 & 50,93 & 563,48 & 0,16 & 0,37 & 4,14 & 25,91 & 11,06 \\
\hline Tocantins & 10,89 & 28,23 & 554,14 & 0,08 & 0,21 & 4,07 & 50,90 & 19,63 \\
\hline Nordeste & 10,11 & 27,47 & 605,55 & $\mathbf{0 , 0 7}$ & $\mathbf{0 , 2 0}$ & 4,45 & $\mathbf{5 9 , 8 7}$ & 22,05 \\
\hline Maranhão & 8,90 & 24,81 & 372,16 & 0,07 & 0,18 & 2,74 & 41,81 & 15,00 \\
\hline Piauí & 5,56 & 17,29 & 469,73 & 0,04 & 0,13 & 3,45 & 84,47 & 27,16 \\
\hline Ceará & 8,80 & 23,52 & 575,13 & 0,06 & 0,17 & 4,23 & 67,03 & 24,45 \\
\hline Rio Grande do Norte & 10,13 & 27,37 & 643,98 & 0,07 & 0,20 & 4,74 & 63,59 & 23,53 \\
\hline Paraíba & 7,09 & 23,25 & 505,85 & 0,05 & 0,17 & 3,72 & 71,38 & 21,76 \\
\hline Pernambuco & 11,53 & 31,23 & 647,49 & 0,08 & 0,23 & 4,76 & 56,14 & 20,74 \\
\hline Alagoas & 13,12 & 31,52 & 665,69 & 0,10 & 0,23 & 4,89 & 50,74 & 21,12 \\
\hline Sergipe & 15,36 & 33,37 & 687,33 & 0,11 & 0,25 & 5,05 & 44,76 & 20,60 \\
\hline Bahia & 13,17 & 30,61 & 674,57 & 0,10 & 0,23 & 4,96 & 51,23 & 22,03 \\
\hline Sudeste & 30,55 & 71,70 & $1.227,26$ & 0,22 & 0,53 & $\mathbf{9 , 0 2}$ & 40,17 & 17,12 \\
\hline Minas Gerais & 19,60 & 47,60 & 929,73 & 0,14 & 0,35 & 6,84 & 47,44 & 19,53 \\
\hline Espírito Santo & 17,48 & 44,33 & 788,19 & 0,13 & 0,33 & 5,80 & 45,08 & 17,78 \\
\hline Rio de Janeiro & 38,41 & 80,73 & $1.437,74$ & 0,28 & 0,59 & 10,57 & 37,43 & 17,81 \\
\hline São Paulo & 41,34 & 88,97 & $1.276,41$ & 0,30 & 0,65 & 9,39 & 30,87 & 14,35 \\
\hline Sul & 27,54 & 65,49 & $1.112,41$ & $\mathbf{0 , 2 0}$ & 0,48 & 8,18 & 40,39 & 16,99 \\
\hline Paraná & 20,62 & 52,35 & 898,37 & 0,15 & 0,38 & 6,61 & 43,57 & 17,16 \\
\hline Santa Catarina & 33,65 & 72,79 & $1.189,25$ & 0,25 & 0,54 & 8,74 & 35,34 & 16,34 \\
\hline Rio Grande do Sul & 33,98 & 77,17 & $1.236,75$ & 0,25 & 0,57 & 9,09 & 36,39 & 16,03 \\
\hline Centro-Oeste & 24,51 & 53,92 & $1.139,88$ & 0,18 & $\mathbf{0 , 4 0}$ & 8,38 & 46,50 & 21,14 \\
\hline Mato Grosso do Sul & 23,73 & 52,46 & $1.104,87$ & 0,17 & 0,39 & 8,12 & 46,56 & 21,06 \\
\hline Mato Grosso & 21,15 & 47,26 & 685,71 & 0,16 & 0,35 & 5,04 & 32,42 & 14,51 \\
\hline Goiás & 24,16 & 52,87 & 985,69 & 0,18 & 0,39 & 7,25 & 40,80 & 18,64 \\
\hline Distrito Federal & 33,68 & 73,61 & $1.849,38$ & 0,25 & 0,54 & 13,60 & 54,00 & $\begin{array}{l}25,12 \\
\text { ontinua) }\end{array}$ \\
\hline
\end{tabular}


(continuação)

\begin{tabular}{|c|c|c|c|c|c|c|c|c|}
\hline \multirow{3}{*}{$\begin{array}{c}\text { Grandes Regiões e } \\
\text { Unidades da } \\
\text { Federação }\end{array}$} & \multicolumn{6}{|c|}{ Renda média familiar per capita } & \multirow{2}{*}{\multicolumn{2}{|c|}{$\begin{array}{l}\text { Relação entre } \\
\text { rendas médias }\end{array}$}} \\
\hline & \multicolumn{3}{|c|}{ Em R\$ } & \multicolumn{3}{|c|}{ Em salário mínimo } & & \\
\hline & $\begin{array}{c}10 \% \\
\text { mais } \\
\text { pobres }\end{array}$ & $\begin{array}{c}40 \% \\
\text { mais } \\
\text { pobres }\end{array}$ & $\begin{array}{l}10 \% \text { mais } \\
\text { ricos }\end{array}$ & $\begin{array}{l}10 \% \\
\text { mais } \\
\text { pobres } \\
\text { (A) }\end{array}$ & $\begin{array}{c}40 \% \\
\text { mais } \\
\text { pobres } \\
\text { (B) }\end{array}$ & $\begin{array}{l}10 \% \\
\text { mais } \\
\text { ricos } \\
(\mathrm{C})\end{array}$ & $\mathrm{C} / \mathrm{A}$ & $\mathrm{C} / \mathrm{B}$ \\
\hline \multicolumn{9}{|c|}{1999} \\
\hline Brasil & 28,26 & 68,32 & $1.511,67$ & $\mathbf{0 , 2 1}$ & $\mathbf{0 , 5 0}$ & 11,12 & 53,48 & 22,13 \\
\hline Norte & 27,51 & 58,00 & $1.097,30$ & $\mathbf{0 , 2 0}$ & $\mathbf{0 , 4 3}$ & 8,07 & 39,89 & 18,92 \\
\hline Rondônia & 37,60 & 81,85 & $1.487,43$ & 0,28 & 0,60 & 10,94 & 39,56 & 18,17 \\
\hline Acre & 27,01 & 61,58 & $1.574,20$ & 0,20 & 0,45 & 11,58 & 58,27 & 25,56 \\
\hline Amazonas & 29,05 & 55,88 & 942,63 & 0,21 & 0,41 & 6,93 & 32,44 & 16,87 \\
\hline Roraima & 35,65 & 86,05 & $1.147,76$ & 0,26 & 0,63 & 8,44 & 32,20 & 13,34 \\
\hline Pará & 25,64 & 53,89 & 988,70 & 0,19 & 0,40 & 7,27 & 39,02 & 18,35 \\
\hline Amapá & 25,95 & 56,25 & 978,43 & 0,19 & 0,41 & 7,19 & 37,71 & 17,39 \\
\hline Tocantins & 22,82 & 50,14 & 930,82 & 0,17 & 0,37 & 6,84 & 40,78 & 18,56 \\
\hline Nordeste & 17,48 & 39,45 & 900,36 & 0,13 & 0,29 & 6,62 & 51,51 & 22,82 \\
\hline Maranhão & 16,97 & 33,82 & 659,58 & 0,12 & 0,25 & 4,85 & 38,88 & 19,50 \\
\hline Piauí & 11,35 & 30,52 & 711,51 & 0,08 & 0,22 & 5,23 & 62,71 & 23,31 \\
\hline Ceará & 14,63 & 37,09 & 874,90 & 0,11 & 0,27 & 6,43 & 59,80 & 23,59 \\
\hline Rio Grande do Norte & 19,28 & 43,79 & $1.012,81$ & 0,14 & 0,32 & 7,45 & 52,52 & 23,13 \\
\hline Paraíba & 17,53 & 41,34 & $1.286,22$ & 0,13 & 0,30 & 9,46 & 73,38 & 31,11 \\
\hline Pernambuco & 18,95 & 43,31 & 978,96 & 0,14 & 0,32 & 7,20 & 51,66 & 22,60 \\
\hline Alagoas & 19,71 & 38,03 & 795,44 & 0,14 & 0,28 & 5,85 & 40,35 & 20,91 \\
\hline Sergipe & 18,14 & 42,97 & $1.057,79$ & 0,13 & 0,32 & 7,78 & 58,30 & 24,61 \\
\hline Bahia & 19,79 & 42,07 & 852,78 & 0,15 & 0,31 & 6,27 & 43,08 & 20,27 \\
\hline Sudeste & 44,87 & 96,55 & $1.784,08$ & $\mathbf{0 , 3 3}$ & 0,71 & 13,12 & 39,76 & 18,48 \\
\hline Minas Gerais & 30,76 & 68,35 & $1.275,22$ & 0,23 & 0,50 & 9,38 & 41,45 & 18,66 \\
\hline Espírito Santo & 32,81 & 70,74 & $1.369,69$ & 0,24 & 0,52 & 10,07 & 41,74 & 19,36 \\
\hline Rio de Janeiro & 51,13 & 105,78 & $1.988,40$ & 0,38 & 0,78 & 14,62 & 38,89 & 18,80 \\
\hline São Paulo & 56,62 & 115,71 & $1.926,30$ & 0,42 & 0,85 & 14,16 & 34,02 & 16,65 \\
\hline Sul & 37,64 & 86,27 & $1.571,63$ & 0,28 & 0,63 & 11,56 & 41,76 & 18,22 \\
\hline Paraná & 33,38 & 76,54 & $1.497,24$ & 0,25 & 0,56 & 11,01 & 44,85 & 19,56 \\
\hline Santa Catarina & 44,91 & 96,17 & $1.420,35$ & 0,33 & 0,71 & 10,44 & 31,62 & 14,77 \\
\hline Rio Grande do Sul & 39,34 & 91,34 & $1.696,47$ & 0,29 & 0,67 & 12,47 & 43,12 & 18,57 \\
\hline Centro-Oeste & 36,04 & 74,72 & $1.581,45$ & 0,27 & $\mathbf{0 , 5 5}$ & 11,63 & 43,88 & 21,16 \\
\hline Mato Grosso do Sul & 34,89 & 72,54 & $1.240,84$ & 0,26 & 0,53 & 9,12 & 35,56 & 17,11 \\
\hline Mato Grosso & 36,40 & 73,78 & $1.120,76$ & 0,27 & 0,54 & 8,24 & 30,79 & 15,19 \\
\hline Goiás & 34,90 & 70,28 & $1.174,68$ & 0,26 & 0,52 & 8,64 & 33,65 & 16,71 \\
\hline Distrito Federal & 41,49 & 97,80 & $2.968,72$ & 0,31 & 0,72 & 21,83 & 71,55 & 30,36 \\
\hline
\end{tabular}

Fonte: Adaptado de IBGE. Síntese de Indicadores Sociais. Disponível em http://www2.ibge.gov.br/ibge/ftp/ftp.php?dir=/Indicadores Sociais/Síntese de Indicadores Sociais 2000. Acesso em: 11/03/02 
Pela observação da Tabela 4 percebe-se que, no ano de 1992, enquanto a renda média dos $10 \%$ de brasileiros mais ricos é de $\mathrm{R} \$ 1.053,09$, a do Distrito Federal é de $\mathrm{R} \$ 1.849,38$, a da região Sudeste $\mathrm{R} \$ 1.227,26$ e a da região Nordeste $\mathrm{R} \$ 605,55$. A maior concentração de renda, quando tomados os $10 \%$ mais ricos e os $10 \%$ mais pobres, é encontrada no Piauí, onde os mais ricos recebem uma renda 84,47 vezes maior que os mais pobres (enquanto a média nacional está em 57,18 vezes). Ao se tomarem os $10 \%$ mais ricos, relacionados aos $40 \%$ mais pobres, essa renda é 27,16 vezes maior (contra uma média nacional de 20,84 vezes). No ano de 1999, as posições foram mantidas com a renda média dos $10 \%$ de brasileiros mais ricos passando para $\mathrm{R} \$ 1.511,67$, a do Distrito Federal para $\mathrm{R} \$ 2.968,72$, a da região Sudeste para R\$1.784,08, e da região Nordeste para R\$900,36. A maior concentração de renda, avaliados os $10 \%$ mais ricos e os $10 \%$ mais pobres, passou a ser a da Paraíba, com os mais ricos recebendo 73,38 vezes a renda dos mais pobres e 31,11 vezes, quando tomados os $10 \%$ mais ricos e os $40 \%$ mais pobres.

Quando analisamos o Brasil comparado a outros países do mundo, a desigualdade também é gritante. $\mathrm{O}$ resultado do relatório feito para comparar a desigualdade de renda dos EUA com a de outros 6 países considerados importantes está na Tabela 5.

Tabela 5 - Desigualdade da renda ao redor do mundo

\begin{tabular}{lccccc}
\hline País & $\begin{array}{c}\text { Quintil } \\
\text { Inferior }\end{array}$ & $\begin{array}{c}\text { Segundo } \\
\text { Quintil }\end{array}$ & $\begin{array}{c}\text { Quintil } \\
\text { Central }\end{array}$ & $\begin{array}{c}\text { Quarto } \\
\text { Quintil }\end{array}$ & $\begin{array}{c}\text { Quintil } \\
\text { Superior }\end{array}$ \\
\hline Alemanha & & & & & \\
Canadá & $9,0 \%$ & $13,5 \%$ & $17,5 \%$ & $22,9 \%$ & $37,1 \%$ \\
Rússia & 7,5 & 12,9 & 17,2 & 23,0 & 39,3 \\
Reino Unido & 7,4 & 12,6 & 17,7 & 24,2 & 38,2 \\
China & 7,1 & 12,8 & 17,2 & 23,1 & 39,8 \\
EUA & 5,5 & 9,8 & 14,9 & 22,3 & 47,5 \\
Chile & 4,8 & 10,5 & 16,0 & 23,5 & 45,2 \\
Brasil & 3,5 & 6,6 & 10,9 & 18,1 & 61,0 \\
& 2,5 & 5,7 & 9,9 & 17,7 & 64,2 \\
\hline
\end{tabular}

Fonte:Adaptado de MANKIW, N. Gregory. Introdução à economia: princípios de micro e macroeconomia. Tradução Maria José Cyhlar Monteiro. 2. ed. Rio de Janeiro: Campus, 2001. p. 441 
Os países se encontram ordenados do mais igual ao mais desigual, na Tabela 5. A Alemanha é o país com distribuição de renda mais igualitária. O quintil mais rico da população detém $37,1 \%$ da renda existente, e o quintil mais pobre, $9 \%$ dela, demonstrando que a população mais rica tem uma renda cerca de quatro vezes superior à da população mais pobre. O Brasil, ocupando o último lugar da lista, registra substancial desigualdade: $64,2 \%$ da renda estão concentrados nas mãos dos mais ricos, e 2,5\% nas mãos dos mais pobres ou, a classe rica tem uma renda 25 vezes superior a da classe mais pobre. Cabe ressaltar que os países não coletam os dados de uma mesma maneira. Uns os levantam com base na renda pessoal da população, e outros utilizam a renda familiar. Com isso, a análise perde o grau de comparabilidade pois, os métodos de coleta usados podem ter sido diferentes.

A perversa estrutura da desigualdade da renda do Brasil pode ser traduzida pela Tabela 6, distribuição da renda ou do consumo, constante do relatório sobre o desenvolvimento mundial 2000/2001, do Banco Mundial, onde estão presentes 105 países, dentre eles alguns miseráveis, como Madagascar, Mali, Nigéria e Zâmbia, com mais da metade da população vivendo abaixo da linha de pobreza, o que, de acordo com Mankiw ${ }^{116}$, é extremamente prejudicial:

"A pobreza é um dos problemas mais difíceis que os formuladores de política s públicas enfrentam. Famílias pobres estão mais sujeitos do que o resto da população a ficar sem teto, à dependência de drogas, à violência doméstica, a problema de saúde, à gravidez na adolescência, ao analfabetismo, ao desemprego e ao baixo rendimento escolar. Indivíduos de famílias pobres têm mais probabilidade tanto de cometer crimes quanto de serem vítimas de crimes. Embora seja difícil separar as causas da pobreza de suas conseqüências, não há dúvida de que a pobreza está associada a vários males econômicos e sociais."

A análise dos dados da Tabela 6 mostra que o Brasil é o país da América do Sul com a pior distribuição de renda, índice de Gini igual a 60,0, e que a Bolívia é o melhor, índice de Gini 42,0. Dentre todos os 105 países relacionados, o Brasil, a República Centro-Africana e Serra Leoa, também na África, apresentam a maior desigualdade, com índice de Gini de 60,0, 61,3 e 62,9 respectivamente. O país que apresenta a

${ }^{116}$ op. cit. p. 451 
Tabela 6 - Distribuição da Renda ou do Consumo

\begin{tabular}{|c|c|c|c|c|c|c|}
\hline \multirow[b]{2}{*}{ Economia } & \multirow[b]{2}{*}{ Ano da pesquisa } & \multirow[b]{2}{*}{$\begin{array}{l}\text { Indice } \\
\text { de Gini }\end{array}$} & \multicolumn{4}{|c|}{ Distribuição \% da renda ou do consumo } \\
\hline & & & $\begin{array}{c}\text { Decil } \\
\text { inferior }\end{array}$ & $\begin{array}{l}\text { Quintil } \\
\text { inferior }\end{array}$ & $\begin{array}{c}\text { Quintil } \\
\text { superior }\end{array}$ & $\begin{array}{c}\text { Decil } \\
\text { superior }\end{array}$ \\
\hline África do Sul & $1993-94^{\mathrm{a}, \mathrm{b}}$ & 59,3 & 1,1 & 2,9 & 64,8 & 45,9 \\
\hline Alemanha & $1994^{\mathrm{c}, \mathrm{d}}$ & 30,0 & 3,3 & 8,2 & 38,5 & 23,7 \\
\hline Argélia & $1995^{\mathrm{a}, \mathrm{b}}$ & 35,3 & 2,8 & 7,0 & 42,6 & 26,8 \\
\hline Austrália & $1994^{\mathrm{c}, \mathrm{d}}$ & 35,2 & 2,0 & 5,9 & 41,3 & 25,4 \\
\hline Áustria & $1987^{\mathrm{c}, \mathrm{d}}$ & 23,1 & 4,4 & 10,4 & 33,3 & 19,3 \\
\hline Bangladesh & $1995-96^{a, b}$ & 33,6 & 3,9 & 8,7 & 42,8 & 28,6 \\
\hline Belarus & $1998^{\mathrm{a}, \mathrm{b}}$ & 21,7 & 5,1 & 11,4 & 33,3 & 20,0 \\
\hline Bélgica & $1992^{\mathrm{c}, \mathrm{d}}$ & 25,0 & 3,7 & 9,5 & 34,5 & 20,2 \\
\hline Bolívia & $1990^{\mathrm{c}, \mathrm{d}}$ & 42,0 & 2,3 & 5,6 & 48,2 & 31,7 \\
\hline Brasil & $1996^{\mathrm{c}, \mathrm{d}}$ & 60,0 & 0,9 & 2,5 & 63,8 & 47,6 \\
\hline Bulgária & $1995^{\mathrm{a}, \mathrm{b}}$ & 28,3 & 3,4 & 8,5 & 37,0 & 22,5 \\
\hline Burkina Faso & $1994^{\mathrm{a}, \mathrm{b}}$ & 48,2 & 2,2 & 5,5 & 55,0 & 39,5 \\
\hline Burundi & $1992^{a, b}$ & 33,3 & 3,4 & 7,9 & 41,6 & 26,6 \\
\hline Camboja & $1997^{\mathrm{a}, \mathrm{b}}$ & 40,4 & 2,9 & 6,9 & 47,6 & 33,8 \\
\hline Canadá & $1994^{\mathrm{c}, \mathrm{d}}$ & 31,5 & 2,8 & 7,5 & 39,3 & 23,8 \\
\hline Cazaquistão & $1996^{\mathrm{a}, \mathrm{b}}$ & 35,4 & 2,7 & 6,7 & 42,3 & 26,3 \\
\hline Chile & $1994^{\mathrm{c}, \mathrm{d}}$ & 56,5 & 1,4 & 3,5 & 61,0 & 46,1 \\
\hline China & $1998^{\mathrm{c}, \mathrm{d}}$ & 40,3 & 2,4 & 5,9 & 46,6 & 30,4 \\
\hline Colômbia & $1996^{\mathrm{c}, \mathrm{d}}$ & 57,1 & 1,1 & 3,0 & 60,9 & 46,1 \\
\hline Coréia & $1993^{a, b}$ & 31,6 & 2,9 & 7,5 & 39,3 & 24,3 \\
\hline Costa do Marfim & $1995^{\mathrm{a}, \mathrm{b}}$ & 36,7 & 3,1 & 7,1 & 44,3 & 28,8 \\
\hline Costa Rica & $1996^{\mathrm{c}, \mathrm{d}}$ & 47,0 & 1,3 & 4,0 & 51,8 & 34,7 \\
\hline Croácia & $1998^{\mathrm{a}, \mathrm{b}}$ & 26,8 & 4,0 & 9,3 & 36,2 & 21,6 \\
\hline Dinamarca & $1992^{\mathrm{c}, \mathrm{d}}$ & 24,7 & 3,6 & 9,6 & 34,5 & 20,5 \\
\hline Egito & $1995^{\mathrm{a}, \mathrm{b}}$ & 28,9 & 4,4 & 9,8 & 39,0 & 25,0 \\
\hline El Salvador & $1996^{\mathrm{c}, \mathrm{d}}$ & 52,3 & 1,2 & 3,4 & 56,5 & 40,5 \\
\hline Equador & $1995^{\mathrm{a}, \mathrm{b}}$ & 43,7 & 2,2 & 5,4 & 49,7 & 33,8 \\
\hline Eslovênia & $1995^{\mathrm{c}, \mathrm{d}}$ & 26,8 & 3,2 & 8,4 & 35,4 & 20,7 \\
\hline Espanha & $1990^{\mathrm{c}, \mathrm{d}}$ & 32,5 & 2,8 & 7,5 & 40,3 & 25,2 \\
\hline Estados Unidos & $1997^{\mathrm{c}, \mathrm{d}}$ & 40,8 & 1,8 & 5,2 & 46,4 & 30,5 \\
\hline Estônia & $1995^{\mathrm{c}, \mathrm{d}}$ & 35,4 & 2,2 & 6,2 & 41,8 & 26,2 \\
\hline Etiópia & $1995^{\mathrm{a}, \mathrm{b}}$ & 40,0 & 3,0 & 7,1 & 47,7 & 33,7 \\
\hline Federação Russa & $1998^{\mathrm{a}, \mathrm{b}}$ & 48,7 & 1,7 & 4,4 & 53,7 & 38,7 \\
\hline Filipinas & $1997^{\mathrm{a}, \mathrm{b}}$ & 46,2 & 2,3 & 5,4 & 52,3 & 36,6 \\
\hline Finlândia & $1991^{\mathrm{c}, \mathrm{d}}$ & 25,6 & 4,2 & 10,0 & 35,8 & 21,6 \\
\hline França & $1995^{\mathrm{c}, \mathrm{d}}$ & 32,7 & 2,8 & 7,2 & 40,2 & 25,1 \\
\hline Gana & $1997^{\mathrm{a}, \mathrm{b}}$ & 32,7 & 3,6 & 8,4 & 41,7 & 26,1 \\
\hline Grécia & $1993^{\mathrm{c}, \mathrm{d}}$ & 32,7 & 3,0 & 7,5 & 40,3 & 25,3 \\
\hline Guatemala & $1989^{\mathrm{c}, \mathrm{d}}$ & 59,6 & 0,6 & 2,1 & 63,0 & 46,6 \\
\hline Guiné & $1994^{\mathrm{a}, \mathrm{b}}$ & 40,3 & 2,6 & 6,4 & 47,2 & $\begin{array}{c}32,0 \\
\text { (continua) }\end{array}$ \\
\hline
\end{tabular}




\begin{tabular}{|c|c|c|c|c|c|c|}
\hline \multirow[b]{2}{*}{ Economia } & \multirow[b]{2}{*}{ Ano da pesquisa } & \multirow[b]{2}{*}{$\begin{array}{l}\text { Indice } \\
\text { de Gini }\end{array}$} & \multicolumn{4}{|c|}{ Distribuição \% da renda ou do consumo } \\
\hline & & & $\begin{array}{c}\text { Decil } \\
\text { inferior }\end{array}$ & $\begin{array}{l}\text { Quintil } \\
\text { inferior }\end{array}$ & $\begin{array}{c}\text { Quintil } \\
\text { superior }\end{array}$ & $\begin{array}{c}\text { Decil } \\
\text { superior }\end{array}$ \\
\hline Honduras & $1996^{\mathrm{c}, \mathrm{d}}$ & 53,7 & 1,2 & 3,4 & 58,0 & 42,1 \\
\hline Hungria & $1996^{\mathrm{c}, \mathrm{d}}$ & 30,8 & 3,9 & 8,8 & 39,9 & 24,8 \\
\hline Iêmen & $1992^{\mathrm{a}, \mathrm{b}}$ & 39,5 & 2,3 & 6,1 & 46,1 & 30,8 \\
\hline Índia & $1997^{\mathrm{a}, \mathrm{b}}$ & 37,8 & 3,5 & 8,1 & 46,1 & 33,5 \\
\hline Indonésia & $1996^{\mathrm{c}, \mathrm{d}}$ & 36,5 & 3,6 & 8,0 & 44,9 & 30,3 \\
\hline Irlanda & $1987^{\mathrm{c}, \mathrm{d}}$ & 35,9 & 2,5 & 6,7 & 42,9 & 27,4 \\
\hline Israel & $1992^{\mathrm{c}, \mathrm{d}}$ & 35,5 & 2,8 & 6,9 & 42,5 & 26,9 \\
\hline Itália & $1995^{\mathrm{c}, \mathrm{d}}$ & 27,3 & 3,5 & 8,7 & 36,3 & 21,8 \\
\hline Jamaica & $1996^{\mathrm{a}, \mathrm{b}}$ & 36,4 & 2,9 & 7,0 & 43,9 & 28,9 \\
\hline Japão & $1993^{\mathrm{c}, \mathrm{d}}$ & 24,9 & 4,8 & 10,6 & 35,7 & 21,7 \\
\hline Jordânia & $1997^{\mathrm{a}, \mathrm{b}}$ & 36,4 & 3,3 & 7,6 & 44,4 & 29,8 \\
\hline Laos & $1992^{\mathrm{a}, \mathrm{b}}$ & 30,4 & 4,2 & 9,6 & 40,2 & 26,4 \\
\hline Lesoto & $1986-87^{a, b}$ & 56,0 & 0,9 & 2,8 & 60,1 & 43,4 \\
\hline Letônia & $1998^{\mathrm{c}, \mathrm{d}}$ & 32,4 & 2,9 & 7,6 & 40,3 & 25,9 \\
\hline Lituânia & $1996^{\mathrm{a}, \mathrm{b}}$ & 32,4 & 3,1 & 7,8 & 40,3 & 25,6 \\
\hline Madagascar & $1993^{a, b}$ & 46,0 & 1,9 & 5,1 & 52,1 & 36,7 \\
\hline Malásia & $1995^{\mathrm{c}, \mathrm{d}}$ & 48,5 & 1,8 & 4,5 & 53,8 & 37,9 \\
\hline Mali & $1994^{\mathrm{a}, \mathrm{b}}$ & 50,5 & 1,8 & 4,6 & 56,2 & 40,4 \\
\hline Marrocos & $1998-99^{\mathrm{a}, \mathrm{b}}$ & 39,5 & 2,6 & 6,5 & 46,6 & 30,9 \\
\hline Mauritânia & $1995^{\mathrm{a}, \mathrm{b}}$ & 38,9 & 2,3 & 6,2 & 45,6 & 29,9 \\
\hline México & $1995^{\mathrm{c}, \mathrm{d}}$ & 53,7 & 1,4 & 3,6 & 58,2 & 42,8 \\
\hline Moçambique & $1996-97^{\mathrm{a}, \mathrm{b}}$ & 39,6 & 2,5 & 6,5 & 46,5 & 31,7 \\
\hline Moldova & $1992^{\mathrm{c}, \mathrm{d}}$ & 34,4 & 2,7 & 6,9 & 41,5 & 25,8 \\
\hline Mongólia & $1995^{\mathrm{a}, \mathrm{b}}$ & 33,2 & 2,9 & 7,3 & 40,9 & 24,5 \\
\hline Nepal & $1995-96^{a, b}$ & 36,7 & 3,2 & 7,6 & 44,8 & 29,8 \\
\hline Nicarágua & $1993^{\mathrm{a}, \mathrm{b}}$ & 50,3 & 1,6 & 4,2 & 55,2 & 39,8 \\
\hline Níger & $1995^{\mathrm{a}, \mathrm{b}}$ & 50,5 & 0,8 & 2,6 & 53,3 & 35,4 \\
\hline Nigéria & $1996-97^{a, b}$ & 50,6 & 1,6 & 4,4 & 55,7 & 40,8 \\
\hline Noruega & $1995^{\mathrm{c}, \mathrm{d}}$ & 25,8 & 4,1 & 9,7 & 35,8 & 21,8 \\
\hline Nova Zelândia & $1991^{\mathrm{c}, \mathrm{d}}$ & 43,9 & 0,3 & 2,7 & 46,9 & 29,8 \\
\hline Países Baixos & $1994^{\mathrm{c}, \mathrm{d}}$ & 32,6 & 2,8 & 7,3 & 40,1 & 25,1 \\
\hline Panamá & $1997^{\mathrm{a}, \mathrm{b}}$ & 48,5 & 1,2 & 3,6 & 52,8 & 35,7 \\
\hline Papua Nova Guiné & $1996^{\mathrm{a}, \mathrm{b}}$ & 50,9 & 1,7 & 4,5 & 56,5 & 40,5 \\
\hline Paquistão & $1996-97^{a, b}$ & 31,2 & 4,1 & 9,5 & 41,1 & 27,6 \\
\hline Paraguai & $1995^{\mathrm{a}, \mathrm{d}}$ & 59,1 & 0,7 & 2,3 & 62,4 & 46,6 \\
\hline Peru & $1996^{\mathrm{c}, \mathrm{d}}$ & 46,2 & 1,6 & 4,4 & 51,2 & 35,4 \\
\hline Polônia & $1996^{\mathrm{c}, \mathrm{d}}$ & 32,9 & 3,0 & 7,7 & 40,9 & 26,3 \\
\hline Portugal & $1994-95^{\mathrm{c}, \mathrm{d}}$ & 35,6 & 3,1 & 7,3 & 43,4 & 28,4 \\
\hline Quênia & $1994^{\mathrm{a}, \mathrm{b}}$ & 44,5 & 1,8 & 5,0 & 50,2 & 34,9 \\
\hline Quirguízia & $1997^{\mathrm{c}, \mathrm{d}}$ & 40,5 & 2,7 & 6,3 & 47,4 & 31,7 \\
\hline Reino Unido & $1991^{\mathrm{c}, \mathrm{d}}$ & 36,1 & 2,6 & 6,6 & 43,0 & 27,3 \\
\hline República Centro-Africana & $1993^{\mathrm{a}, \mathrm{b}}$ & 61,3 & 0,7 & 2,0 & 65,0 & 47,7 \\
\hline
\end{tabular}


(continuação)

\begin{tabular}{|c|c|c|c|c|c|c|}
\hline \multirow[b]{2}{*}{ Economia } & \multirow[b]{2}{*}{ Ano da pesquisa } & \multirow[b]{2}{*}{$\begin{array}{l}\text { Indice } \\
\text { de Gini }\end{array}$} & \multicolumn{4}{|c|}{ Distribuição \% da renda ou do consumo } \\
\hline & & & $\begin{array}{c}\text { Decil } \\
\text { inferior }\end{array}$ & $\begin{array}{l}\text { Quintil } \\
\text { inferior }\end{array}$ & $\begin{array}{l}\text { Quintil } \\
\text { superior }\end{array}$ & $\begin{array}{c}\text { Decil } \\
\text { superior }\end{array}$ \\
\hline República Dominicana & $1996^{\mathrm{c}, \mathrm{d}}$ & 48,7 & 1,7 & 4,3 & 53,7 & 37,8 \\
\hline República Eslovaca & $1992^{\mathrm{c}, \mathrm{d}}$ & 19,5 & 5,1 & 11,9 & 31,4 & 18,2 \\
\hline República Tcheca & $1996^{\mathrm{c}, \mathrm{d}}$ & 25,4 & 4,3 & 10,3 & 35,9 & 22,4 \\
\hline Romênia & $1994^{\mathrm{c}, \mathrm{d}}$ & 28,2 & 3,7 & 8,9 & 37,3 & 22,7 \\
\hline Ruanda & $1983-85^{a, b}$ & 28,9 & 4,2 & 9,7 & 39,1 & 24,2 \\
\hline Senegal & $1995^{\mathrm{a}, \mathrm{b}}$ & 41,3 & 2,6 & 6,4 & 48,2 & 33,5 \\
\hline Serra Leoa & $1989^{\mathrm{a}, \mathrm{b}}$ & 62,9 & 0,5 & 1,1 & 63,4 & 43,6 \\
\hline Sri Lanka & $1995^{\mathrm{a}, \mathrm{b}}$ & 34,4 & 3,5 & 8,0 & 42,8 & 28,0 \\
\hline Suécia & $1992^{\mathrm{c}, \mathrm{d}}$ & 33,1 & 2,6 & 6,9 & 40,3 & 25,2 \\
\hline Suiça & $1992^{\mathrm{c}, \mathrm{d}}$ & 25,0 & 3,7 & 9,6 & 34,5 & 20,1 \\
\hline Tailândia & $1998^{\mathrm{a}, \mathrm{b}}$ & 41,4 & 2,8 & 6,4 & 48,4 & 32,4 \\
\hline Tanzânia & $1993^{a, b}$ & 38,2 & 2,8 & 6,8 & 45,5 & 30,1 \\
\hline Tunísia & $1990^{\mathrm{a}, \mathrm{b}}$ & 40,2 & 2,3 & 5,9 & 46,3 & 30,7 \\
\hline Turcomênia & $1998^{\mathrm{a}, \mathrm{b}}$ & 40,8 & 2,6 & 6,1 & 47,5 & 31,7 \\
\hline Turquia & $1994^{\mathrm{a}, \mathrm{b}}$ & 41,5 & 2,3 & 5,8 & 47,7 & 32,3 \\
\hline Ucrânia & $1996^{\mathrm{a}, \mathrm{b}}$ & 32,5 & 3,9 & 8,6 & 41,2 & 26,4 \\
\hline Uganda & $1992-93^{\mathrm{a}, \mathrm{b}}$ & 39,2 & 2,6 & 6,6 & 46,1 & 31,2 \\
\hline Uruguai & $1989^{\mathrm{c}, \mathrm{d}}$ & 42,3 & 2,1 & 5,4 & 48,3 & 32,7 \\
\hline Uzbequistão & $1993^{\mathrm{c}, \mathrm{d}}$ & 33,3 & 3,1 & 7,4 & 40,9 & 25,2 \\
\hline Venezuela & $1996^{\mathrm{c}, \mathrm{d}}$ & 48,8 & 1,3 & 3,7 & 53,1 & 37,0 \\
\hline Vietnã & $1998^{a, b}$ & 36,1 & 3,6 & 8,0 & 44,5 & 29,9 \\
\hline Zâmbia & $1996^{\mathrm{a}, \mathrm{b}}$ & 49,8 & 1,6 & 4,2 & 54,8 & 39,2 \\
\hline Zimbábue & $1990-91^{\mathrm{a}, \mathrm{b}}$ & 56,8 & 1,8 & 4,0 & 62,3 & 46,9 \\
\hline
\end{tabular}

Nota: a. Os dados referem-se a parcelas de consumo por percentis da população. b. Dados classificados pelo consumo per capita. c. Os dados referem-se a parcelas de renda por percentis da população. d. Dados classificados pela renda per capita.

Fonte: Adaptado de BANCO MUNDIAL. Relatório sobre o desenvolvimento mundial 2000/2001. Disponível em http://www.worldbank.org/poverty/portuguese/wdr/tab05.pdf. Acesso em: 11/03/02.

menor concentração de renda é a República Eslovaca, na Europa, com índice de Gini de 19,5 e onde os $10 \%$ mais pobres da população concentram $5,1 \%$ da renda total, enquanto os $10 \%$ mais ricos detêm $18,2 \%$, ou seja, uma renda 3,57 vezes maior. No Brasil, os $10 \%$ mais pobres da população concentram apenas $0,9 \%$ da renda total e os $10 \%$ mais ricos, $47,6 \%$, uma renda 52,89 vezes maior. Esse relatório mostra que o índice de Gini, na maioria dos países apresentados, não passa de 40,0. 
Segundo Rocha ${ }^{117}$,

'Os países nos quais ainda persiste a incidência de pobreza absoluta podem ser classificados em dois grupos: o primeiro é formado por aqueles nos quais a renda nacional é insuficiente para garantir o mínimo considerado indispensável a cada um de seus cidadãos. Desse modo, a renda per capita é baixa e a pobreza absoluta inevitável quaisquer que sejam as condições de sua distribuição.

O Brasil se classifica no segundo grupo de países onde a pobreza absoluta ainda persiste: aqueles nos quais o produto nacional é suficientemente elevado para garantir o mínimo necessário a todos, de modo que a pobreza resulta da má distribuição de renda. Com renda anual per capita de $R \$ 5.500$ - portanto, bem acima de qualquer valor que possa ser realisticamente associado à linha de pobreza - a incidência de pobreza absoluta no Brasil decorre da forte desigualdade na distribuição de rendimentos."

Ou seja, como a renda per capita no Brasil é superior a qualquer valor relacionado à linha de pobreza, a persistência da pobreza, quando relacionada à renda, pode ser associada à péssima distribuição dos rendimentos. Somos um país de pobres, com extrema injustiça e desigualdade, mas não um país pobre.

\subsubsection{A renda do trabalhador}

O trabalho é um dos fatores de produção, e está voltado à transformação da natureza com o objetivo de satisfazer as necessidades do homem. Ao longo da historia, a humanidade passou por diversas fases, ressaltadas por Huberman ${ }^{118}$ : o sistema familiar, que vigorou no princípio da Idade Média no qual os membros de uma família produziam artigos para seu próprio consumo e não para a venda ou com o objetivo de atender ao mercado; o sistema de corporações, dirigida para um mercado pequeno e estável, onde os trabalhadores não vendiam seu trabalho, mas o produto dele; o sistema doméstico, com a produção realizada em casa para um mercado em crescimento, que teve lugar do século XVI ao XVIII, donde surge a tarefa assalariada; o sistema fabril, onde a produção é realizada fora de casa, nas dependências do empregador e sob sua rigorosa supervisão, para um mercado cada

${ }^{117}$ ROCHA, Sonia. Pobreza e desigualdade no Brasil: o esgotamento dos efeitos do Plano Real. IPEA: Rio de Janeiro, 2001 p. 2-3. (Texto para discussão $n^{\circ} \quad 721$ ). Disponível em http://www.ipea.gov.br/pub/td/td_2000/td0721.pdf. Acesso em: 11/03/02

${ }^{118}$ HUBERMAN, Leo. História da riqueza do homem. Tradução Waltensir Dutra. 17. ed. Rio de Janeiro: Zahar, 1981. p. 125 
vez maior e oscilante e os trabalhadores já não são mais independentes, deixando a habilidade de ser tão importante quanto antes, devido ao uso de máquinas, com o capital tornando-se mais necessário que nunca. Esse sistema vigorou do século XIX até os dias de hoje. A partir do sistema doméstico o preço do trabalho é constituído pela taxa de salário, que apesar de ter um mercado de trabalho semelhante ao de outros bens, está muito longe de ser igual, pois o trabalho não é apenas um bem: ele envolve pessoas ${ }^{119}$. Com o advento do capitalismo, o salário se tornou a forma dominante de pagamento de mão-de-obra ${ }^{120}$. Ressalte-se que esta é uma característica do capitalismo.

Conforme Seldon e Pennance ${ }^{121}$, salário,

'No seu mais amplo sentido econômico, é a recompensa do fator de produção trabalho e inclui qualquer renda proveniente de emprego, renda de emprego autônomo, gratificação, etc.; num sentido econômico mais estrito, define somente a renda de um emprego - a remuneração dos operários e dos empregados em geral."

Na concepção de Smith $^{122}$, numa obra escrita em 1773, os trabalhadores desejam ganhar o máximo possível, enquanto os patrões querem pagar o mínimo possível. Então, os primeiros procuram associar-se entre si para aumentar os salários e os patrões fazem o mesmo para baixá-los.

Como forma de regular e regulamentar as relações conflituosas entre patrões e empregados, garantindo proteção à parte mais fraca delas, surgiu o conjunto de leis denominadas de legislação trabalhista, promulgadas inicialmente na Inglaterra, na segunda metade do século XIX, e posteriormente, com a assinatura do Tratado de Versalhes, em 1919, criando a Organização Internacional do Trabalho (OIT), que passou a discutir as questões trabalhistas em âmbito internacional ${ }^{123}$. Anteriormente, a preocupação em estabelecer normas legais com o foco na proteção ao trabalho do

\footnotetext{
${ }^{119}$ WONNACOTT, P.. WONNACOTT, R. op. cit. p. 473

${ }^{120}$ SANDRONI, Paulo. op. cit. p. 541

${ }^{121}$ op. cit. p. 419

${ }^{122}$ SMITH, Adam. A riqueza das nações: investigação sobre sua natureza e suas causas. Tradução de Luiz João Baraúna. São Paulo: Abril Cultural, 1983, Vol. I. p. 91

${ }^{123}$ SANDRONI, Paulo. op. cit. p. 608
} 
trabalhador concretizou-se na Constituição Mexicana de 1917, que dedicou 30 artigos aos direitos sociais e do trabalhador ${ }^{124}$.

No Brasil, a questão trabalhista foi deixada ao confronto de patrões e empregados, até 1918, quando a Câmara dos Deputados criou a Comissão de Legislação Social, sob pressão das lutas operárias dirigidas pelos anarquistas ${ }^{125}$, e do estado de greve instalado em todos os cantos do país. Como resultado do seu trabalho foi decretada a Lei de Acidentes de Trabalho, que encontrou grande resistência do patronato (1919).

Em 1923, com a promulgação da Lei Elói Mendes, foi instituída a Caixa de Aposentadorias e Pensões para os ferroviários, garantindo-lhes a estabilidade aos dez anos de serviço. Também, nesse mesmo ano, foi criado o Departamento Nacional de Trabalho, com o objetivo de concretizar os compromissos advindos do Tratado de Versalhes.

Em 1925, foi criada a Lei de Férias, quinze dias ao ano. Após a Revolução de 1930, foi criado o Ministério do Trabalho, Indústria e Comércio, entregue a Lindolpho Collor, e aprovada a Lei Sindical (1931), e o Estado passou a intervir diretamente nas questões trabalhistas por meio de uma série de regulamentos, que culminaram na Consolidação das Leis do Trabalho (CLT), em 1943, durante o governo Getúlio Vargas, que em 1940 já havia instituído a legislação do salário mínimo, que tinha como objetivo aumentar a renda do trabalho, assegurando ao trabalhador e à sua família a satisfação de um conjunto de necessidades básicas: alimentação, vestuário, higiene e transporte e, em 1939, criado a Justiça do Trabalho. O sistema do Fundo de Garantia por Tempo de Serviço (FGTS) surge em 1966, e o Programa de Integração Social do trabalhador em 1970. O ano de 1983 é marcado, além da explosão das greves, pela criação da CUT, CONCLAT e CGT, como verdadeiras confederações gerais $^{126}$.

\footnotetext{
${ }^{124}$ TRIBUNAL SUPERIOR DO TRABALHO. Proteção do trabalhador. Disponível em http://www.tst.gov.br/ASCS/historia1.htm. Acesso em: 05/03/02.

${ }^{125} \mathrm{Em}$ 1917, em São Paulo, um operário morreu no conflito entre grevistas e policiais.

${ }^{126}$ SANDRONI, Paulo. op. cit. p. 608 , WONNACOTT, P.. WONNACOTT, R. op. cit. p. 481 e SUSSEKIND, Arnaldo. MARANHÃO, Délio. VIANNA, Segadas. Instituições de Direito do Trabalho. 14. ed. São Paulo: LTD, 1993. v. 1. p. 47-63.
} 
A Constituição de 1988, promulgada em 5 de outubro ${ }^{127}$, estabeleceu vários avanços com relação à legislação trabalhista, dentre os quais: a ampliação do número de itens que o salário mínimo deve atender, incluindo o lazer e a previdência social; a redução da jornada de trabalho semanal de 48 para 44 horas; o pagamento das horas extras com pelo menos $50 \%$ de acréscimo sobre as horas normais; o gozo de férias anuais remuneradas com, pelo menos, um terço a mais que o salário normal; a proteção contra despedida arbitrária ou sem justa causa; o seguro-desemprego; a licença paternidade de cinco dias; a ampliação da licença maternidade para 120 dias; a extensão aos trabalhadores domésticos, dos direitos ao salário mínimo, à licença maternidade, ao décimo terceiro salário, ao repouso semanal remunerado, ao aviso prévio proporcional ao tempo de serviço, à aposentadoria e à incorporação à Previdência Social; a livre associação profissional ou sindical e a unidade sindical.

Um novo marco tem lugar em 2001, com a aprovação do Projeto de Lei 5.483 pela Câmara do Deputados ${ }^{128}$, alterando algumas regras da Consolidação das Leis do Trabalho (CLT), que rege a relação entre trabalhadores e patrões desde 1943, sem nunca ter sido revisada. É o chamado projeto de flexibilização da CLT, que procedeu alterações no seu artigo 618 - Das Convenções Coletivas de Trabalho, estabelecendo que as condições de trabalho ajustadas mediante convenção ou acordo coletivo prevalecem sobre o disposto em lei, desde que não contrariem a Constituição Federal e as normas de segurança e saúde do trabalho. Esse projeto dividiu a opinião das pessoas em geral, temendo que se perdessem direitos anteriormente conquistados. Entretanto, segundo Pastore ${ }^{129}$, 'O seu grande mérito está na introdução de um novo conceito - o de que empregados e empregadores podem negociar condições de trabalho diferentes da lei e o que for negociado vale tanto quanto a lei." Espera-se que sim, e que principalmente não diminua a já tão baixa renda do empregado no

\footnotetext{
127 BRASIL. Constituição (1988). Constituição da República Federativa do Brasil . Brasília, DF: Senado, 1988. Art. $7^{\circ}$ a 11.

${ }^{128}$ BRASIL. Projeto de Lei no 5.483 de 4 de outubro de 2001. Altera o artigo 618 da Consolidação das Leis do Trabalho - CLT.

129 PASTORE, José. CLT: o que pode e o que não pode ser negociado. Disponível em http://www.josepastore.com.br/artigos/relacoestrabalhistas/153.htm . Acesso em: 05/03/02
} 
Brasil pois, de acordo com Barros, Henriques e Mendonça ${ }^{130}$, "A renda do trabalho no Brasil é cerca de 1/3 da renda do trabalho nos países industrializados”.

${ }^{130}$ op. cit. p. 6 


\section{CAPÍTULO 3 - ASPECTOS PRÁTICOS DA DVA}

\subsection{Introdução}

Para análise dos aspectos práticos que serão tratados nesse capítulo, será utilizado o modelo de DVA desenvolvido pela FIPECAFI, apresentado no capítulo 2, que é reproduzido na Figura 8.

\section{Figura 8 - DVA modelo FIPECAFI}

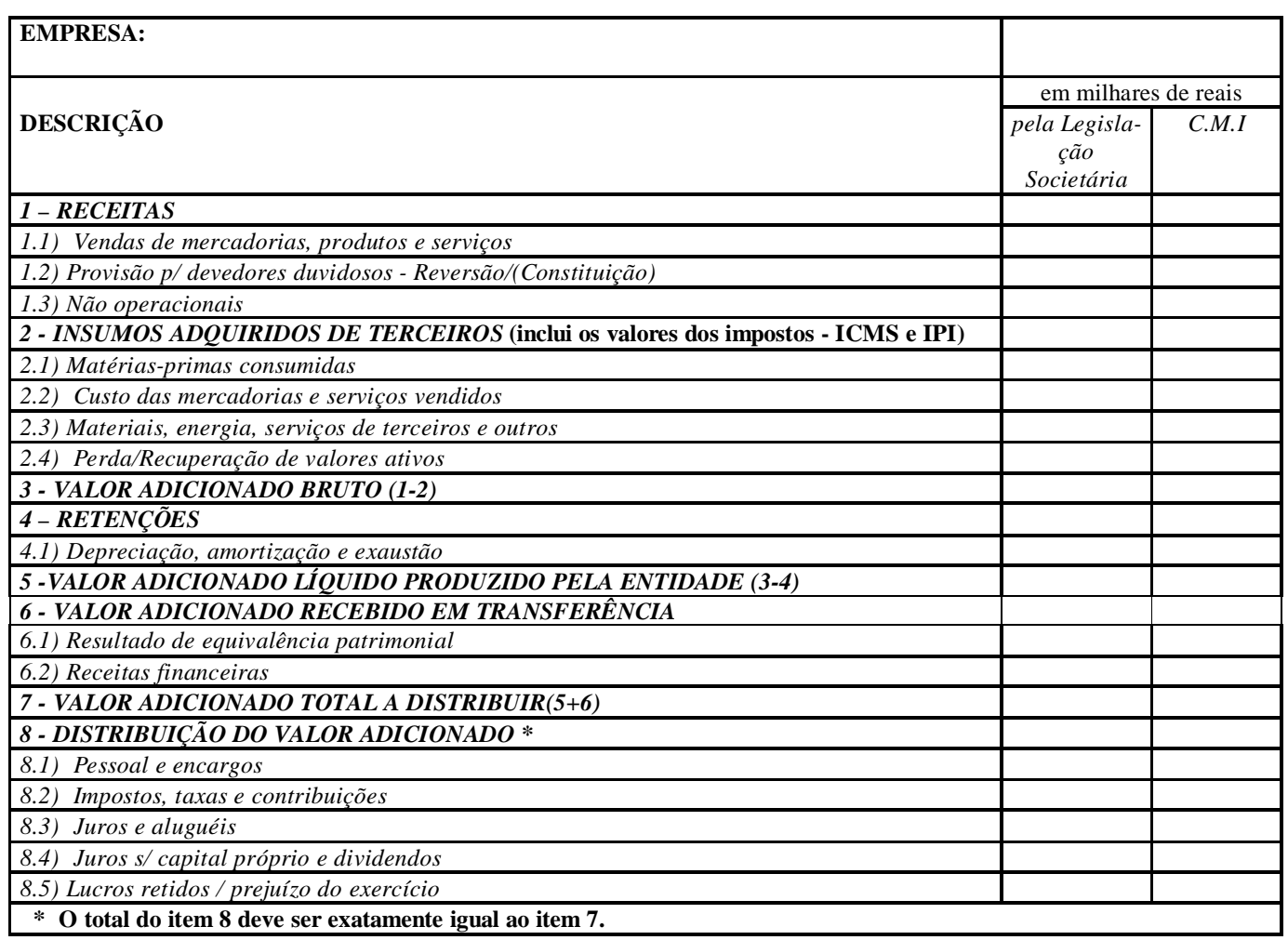

A DVA deverá ser referente ao exercício social da empresa. 


\subsection{Como fazer}

O referido modelo permite que os dados para sua elaboração sejam extraídos das contas já utilizadas pela contabilidade, principalmente aqueles constantes da DRE.

Alguma dificuldade poderá ser encontrada apenas no preenchimento do item 2 Insumos adquiridos de terceiros, ou também com relação às despesas, que geralmente são agrupadas por áreas e/ou atividades da empresa, conforme relata De Luca $^{131}$ :

'Infelizmente as empresas não costumam evidenciar a composição dos custos dos produtos/serviços vendidos e dos estoques; daí faz-se necessária a segregação desses elementos por tipo de custo - matéria-prima, mão-de-obra, gastos gerais de fabricação - bem como por origem, ou seja, os materiais devem ser classificados entre aqueles adquiridos externamente e os de fabricação própria, e os serviços, entre aqueles prestados por terceiros e os obtidos internamente."

Essa dificuldade pode ser facilmente superada com a segregação dos itens que compõem os custos e as despesas, identificando-os por origem (interna ou externa), o que é obtido por meio da elaboração competente de um plano de contas para a empresa, já com o objetivo de proceder à DVA.

A primeira parte da DVA (itens de 1 a 7) demonstra a formação do valor adicionado, e a segunda parte (item 8), a sua distribuição pelos diversos agentes econômicos que ajudaram a formá-lo.

A seguir será construído um exemplo numérico, baseado no de $\operatorname{Santos}^{132}$, para elaboração da DVA de uma empresa industrial, a partir das informações contábeis, e de acordo com as instruções de preenchimento que acompanham o modelo elaborado pela FIPECAFI.

\footnotetext{
${ }^{131}$ DE LUCA, Márcia Martins Mendes. A contribuição da demonstração do valor adicionado no processo de mensuração do PIB e em algumas análises macroeconômicas. Tese de doutoramento - Faculdade de Economia e Contabilidade da Universidade de São Paulo. São Paulo: FEA/USP, 1996. p. 69.

132 SANTOS, Ariovaldo dos. Demonstração contábil do valor adicionado- DVA- Um instrumento para medição da geração e distribuição de riqueza das empresas. Tese de Livre Docência - Faculdade de Economia e Contabilidade da Universidade de São Paulo. São Paulo: FEA/USP, 1999. p. 130-149.
} 


\subsubsection{Exemplo de elaboração de DVA}

Saldos iniciais considerados:

Caixa/Bancos....

15.000

Clientes.

6.500

PDD.

Investimentos 3.000

Máquinas 10.000

Móveis e Utensílios 5.000

Depreciação Acumulada. 3.000

Capital 35.000

Operações realizadas no período:

1. Compra de matéria-prima à vista no valor de $\$ 1.800,00$ (valor líquido $\$$ $1.230,00)$, com incidência de ICMS de $18 \%(\$ 270,00)$ e IPI de $20 \%$ (\$ $300,00)$.

2. Compra de materiais secundários à vista $\$ 300,00$ (valor líquido $\$ 205,00$ ), com incidência de ICMS de $18 \%$ (\$ 45,00) e IPI de $20 \%$ (\$50,00).

3. Pagamento de funcionários no valor de $\$ 3.000,00$, sendo que $22 \%$ referemse a encargos com INSS. 70\% do valor foram pagos a funcionários da produção e os $30 \%$ restantes aos funcionários administrativos.

4. Taxa de depreciação do maquinário da produção e dos móveis e utensílios da administração, de $10 \%$.

5. Pagamento de aluguéis: $\$ 500,00$ do edifício da administração e $\$ 600,00$ da fábrica.

6. Toda a produção iniciada foi acabada dentro do período.

7. Venda de $80 \%$ dos estoques de produtos acabados por $\$ 18.000,00$, sendo $\$$ $10.000,00$ à vista e o restante à prazo. Incidência de $18 \%$ de ICMS (\$ $2.700,00)$ e $20 \%$ de IPI $(\$ 3.000,00)$.

8. Receita de equivalência patrimonial \$300,00. 
9. Receita financeira $\$ 200,00$.

10. Provisão para devedores duvidosos no período $\$ 550,00$.

11. Distribuição de 50\% do lucro líquido como dividendos.

A demonstração do resultado do exercício consta da Figura 9.

\section{Figura 9 - Demonstração do Resultado do Exercício}

\begin{tabular}{|c|c|c|}
\hline Faturamento bruto & & 18.000 \\
\hline (-) IPI faturado & & $(3.000)$ \\
\hline RECEITA BRUTA DE VENDAS & & 15.000 \\
\hline \multicolumn{3}{|l|}{ (-) Deduções da receita bruta } \\
\hline ICMS sobre vendas & & $(2.700)$ \\
\hline RECEITA LÍQUIDA & & 12.300 \\
\hline \multicolumn{3}{|l|}{ (-) CPV } \\
\hline Mão-de-obra & 1.310 & \\
\hline Encargos sociais & 370 & \\
\hline Matéria-prima & 984 & \\
\hline Materiais secundários & 164 & \\
\hline \multicolumn{3}{|l|}{ Outros gastos de produção } \\
\hline Aluguel & 480 & \\
\hline Depreciação & 800 & $(4.108)$ \\
\hline LUCRO BRUTO & & 8.192 \\
\hline \multicolumn{3}{|l|}{ (-) Despesas operacionais } \\
\hline \multicolumn{3}{|l|}{ Despesa pessoal } \\
\hline Mão-de-obra & 702 & \\
\hline Encargos sociais & 198 & (900) \\
\hline \multicolumn{3}{|l|}{ Despesas administrativas } \\
\hline Aluguéis & 500 & \\
\hline Depreciação & 500 & \\
\hline Despesas PDD & 550 & $(1.550)$ \\
\hline \multicolumn{3}{|l|}{ Outras receitas operacionais } \\
\hline Receita financeira & 200 & \\
\hline Resultado equivalência patrimonial & 300 & 500 \\
\hline LUCRO ANTES DOS IMPOS TOS & & 6.242 \\
\hline (-) IR/CSL (23\%) & & (1.436) \\
\hline LUCRO LÍQUIDO & & 4.806 \\
\hline
\end{tabular}

A demonstração do valor adicionado do exercício está representada na Figura 10. 
Figura 10 - Demonstração do Valor Adicionado

\begin{tabular}{|l|c|}
\hline 1 - RECEITAS & 17.450 \\
\hline 1.1) Vendas de mercadorias, produtos e serviços & 18.000 \\
\hline 1.2) Provisão p/ devedores duvidosos - Reversão/(Constituição) & $(550)$ \\
\hline 1.3) Não operacionais & \\
\hline 2 - INSUMOS ADQUIRIDOS DE TERCEIROS (inclui os valores dos impostos - ICMS e IPI) & 1.680 \\
\hline 2.1) Matérias-primas consumidas & 1.440 \\
\hline 2.2) Custo das mercadorias e serviços vendidos & \\
\hline 2.3) Materiais, energia, serviços de terceiros e outros & 240 \\
\hline 2.4) Perda/Recuperação de valores ativos & \\
\hline 3 - VALOR ADICIONADO BRUTO (1-2) & 15.770 \\
\hline 4 - RETENÇÕES & \\
\hline 4.1) Depreciação, amortização e exaustão & 1.300 \\
\hline 5 -VALOR ADICIONADO LÍQUIDO PRODUZIDO PELA ENTIDADE (3-4) & 14.470 \\
\hline 6 - VALOR ADICIONADO RECEBIDO EM TRANSFERÊNCIA & 500 \\
\hline 6.1) Resultado de equivalência patrimonial & 300 \\
\hline 6.2) Receitas financeiras & 200 \\
\hline 7 - VALOR ADICIONADO TOTAL A DIS TRIBUIR(5+6) & 14.970 \\
\hline 8 - DIS TRIBUIÇÃO DO VALOR ADICIONADO & 14.970 \\
\hline 8.1) Pessoal e encargos & 2.012 \\
\hline 8.2) Impostos, taxas e contribuiç̃̃es & 7.172 \\
\hline 8.3) Juros e aluguéis & 980 \\
\hline 8.4) Juros s/ capital próprio e dividendos & 2.403 \\
\hline 8.5) Lucros retidos / prejuízo do exercício & 2.403 \\
\hline
\end{tabular}

As parcelas componentes da Demonstração do Valor Adicionado serão descritas a seguir:

\section{Receitas}

1.1 Vendas de mercadorias, produtos e serviços - valor transferido da DRE, faturamento bruto, $\$ 18.000,00$, considerados os impostos, ou seja, estão incluídos o ICMS e o IPI. Se a empresa não for contribuinte do IPI, o valor a ser buscado é o da receita bruta de vendas.

1.2 Provisão para devedores duvidosos - Reversão/(Constituição) - valor da provisão realizada no período, também transferido da DRE. Caso haja reversão de provisão no período, deverá ser considerada a diferença entre a reversão e a constituição. 
2. Insumos adquiridos de terceiros.

2.1 Matérias-primas consumidas - foram considerados os valores das matériasprimas consumidas no período e que foram levados ao CPV, \$ 984,00 (\$1.230,00 X 0,80), acrescidos dos impostos incidentes sobre as compras, \$216,00 (\$984,00 X 0,18/0,82) de ICMS e \$ \$240,00 (\$ 1.200,00 X 0,20) de IPI, diferentemente da DRE, onde são considerados os valores das matérias-primas, líquidos dos impostos.

2.3 Materiais, energia, serviços de terceiros e outros - aqui também foram considerados os valores dos materiais secundários consumidos no período e que fizeram parte do CPV, acrescidos do ICMS e do IPI. Material secundário \$164,00 (\$ 205,00 X 0,80), ICMS \$36,00\$164,00 X 0,18/0,82) e IPI \$40,00 (\$200,00 X $0,20)$.

3. Valor adicionado bruto - diferença entre a receita, $\$ 17.450,00$, e os insumos adquiridos de terceiros, $\$ 1.680,00$.

\section{Retenções}

4.1 Depreciação, amortização e exaustão - foram computados tanto os valores incluídos no CPV, \$ 800,00 (\$1.000,00 X 0,80), quanto a despesa de depreciação da parte administrativa, $\$ 500,00$.

5. Valor adicionado líquido produzido pela entidade - diferença entre o valor adicionado bruto, $\$ 15.770,00$ e as retenções, $\$ 1.300,00$.

6. Valor adicionado recebido em transferência

6.1 Resultado da equivalência patrimonial - não é uma receita produzida pela empresa, mas um valor, $\$ 300,00$, que foi ou será recebido, e que, portanto, deve ser distribuído.

6.2 Receitas financeiras - da mesma forma que a equivalência patrimonial, não se trata de receita gerada pela empresa, mas recebida ou a receber de terceiros, $\$$ 200,00. 
7. Valor adicionado total a distribuir - somatório do valor adicionado líquido produzido pela entidade, $\$ 14.470,00$, e daquele recebido em transferência, $\$ 500,00$. O valor desse item deve ser igual ao da distribuição do valor adicionado.

\section{Distribuição do valor adicionado}

8.1 Pessoal e encargos - valor da mão-de-obra (salário, férias, $13^{\circ}$ salário, FGTS, e outros) do pessoal envolvido na produção e levada ao CPV, \$1.310,00 (\$1.638,00 X 0,80), mais a mão-de-obra do pessoal da área administrativa, $\$ 702,00$.

8.2 Impostos, taxas e contribuições - nesse item foram incluídos os valores de: Imposto de renda e Contribuição social, \$1.436,00, acrescidos das contribuições ao INSS, tanto do pessoal da produção, \$370,00 (\$ 462,00 X 0,80), quanto do administrativo, $\$ 198,00$, e do ICMS e IPI. Estes dois últimos foram lançados pela diferença entre os valores incidentes sobre as vendas, constantes da DRE, \$ 2.700,00 e $\$ 3.000,00$, respectivamente, e aqueles incidentes sobre os insumos adquiridos de terceiros, \$252,00 (sendo $\$ 216,00$ sobre a matéria-prima e $\$ 36,00$ sobre o material secundário consumidos) e \$280,00 de IPI (\$240,00 sobre matéria-prima e \$40,00 sobre material secundário), ou seja, o valor pago ou devido pela empresa, após as compensações. Os valores somados foram: \$ 1.436,00 de IR/CSL, \$ 568,0 de INSS, $\$ 2.448,00$ de ICMS e $\$ 2.720,00$ de IPI.

8.3 Juros e aluguéis - é o montante pago ou devido aos fornecedores de capital nesse exemplo, os aluguéis da fábrica, $\$ 480,00(\$ 600,00$ X 0,80) e da administração $\$ 500,00$.

8.4 Juros sobre capital próprio e dividendos - constitui-se na remuneração do proprietário, ou na parcela do valor agregado destinada aos sócios ou acionistas. Os dividendos de $\$ 2.403,00$ foram integralmente considerados.

8.5 Lucros retidos/prejuízo do exercício - refere-se ao valor do lucro que não foi distribuído aos donos e ficou retido na empresa $\$ 2.403,00$.

Deve-se observar que, nos itens componentes da DVA Pessoal e Encargos, Matériaprima consumida, Materiais, Energia, Serviços de terceiros e outros, Retenções e Juros e Aluguéis, constam, além de toda a despesa referente à parte administrativa, quando pertinente, apenas os valores que foram apropriados ao CPV (0,80 dos 
produtos que foram vendidos), pois o restante dos produtos, no valor de $\$ 1.027,00$, ainda continua em estoque, não devendo fazer parte da DVA. O valor dos produtos em estoque está assim constituído: \$ 328,00 de mão-de-obra, \$ 92,00 de encargos sociais, \$246,00 de matéria-prima, \$41,00 de materiais secundários, $\$ 120,00$ de aluguel e \$200,00 de depreciação.

\subsection{Tratamento de alguns dos elementos que compõem a DVA}

Na construção da DVA, alguns aspectos referentes aos elementos que compõem a demonstração são considerados polêmicos.

\subsubsection{Impostos}

O primeiro deles é quanto à inclusão ou não do governo como beneficiário da distribuição do valor adicionado. Conforme é observado por De Luca ${ }^{133}$, existem dúvidas quanto ao governo poder ser incluído como elemento componente para a distribuição do valor adicionado. Essa autora, citando Gray e Maunders ${ }^{134}$, ressalta que, se o governo for visto como um membro participativo da criação da riqueza da empresa, será incluído na distribuição do valor adicionado; entretanto, se ele não é visto como participante, todos os impostos deverão ser tratados como "externos", fazendo parte do cálculo do valor adicionado. A apresentação dos itens que fazem parte do valor adicionado seria, então, feita pelo valor bruto, evidenciando-se o valor do imposto, de forma a possibilitar aos usuários conhecer o total dos recursos que foram destinados ao governo na forma de impostos. Essa discussão tem lugar porque, conceitualmente, os fatores de produção são compostos por capital, terra e trabalho, ou seja, a transformação, pela empresa, de recursos intermediários em produtos e serviços só é possível pelo emprego desses fatores, e dentre eles não consta o governo. Mas, atualmente já estão sendo reconhecidos outros fatores de produção, como tecnologia, capacidade empresarial e a própria empresa. O papel do governo

\footnotetext{
${ }^{133}$ DE LUCA, Márcia Martins Mendes. Demonstração do valor adicionado. Dissertação de mestrado Faculdade de Economia e Contabilidade da Universidade de São Paulo. São Paulo: FEA/USP, 1991. p. 65-66. ${ }^{134}$ GRAY, Sidney e MAUNDERS, Keith. Value added reporting: uses and measurement. London: The Association of Certified Accountants, junho, 1980. In: DE LUCA, Márcia Martins Mendes. op. cit. p. 66.
} 
como membro participante na geração da riqueza da empresa seria de apoio às estruturas social, política e econômica que permitem à empresa operar no seu ambiente. Mais serventia teria a polêmica, se girasse em torno da evidenciação segregada do valor adicionado destinado à União, ao Estado e ao Município pois, nos modelos de DVAs apresentados no capítulo 2, tanto o desenvolvido pela FIPECAFI, quanto os de outros países consideram o governo como beneficiário da distribuição sendo portanto, responsável pela criação da riqueza.

Outros itens passíveis de discussão na elaboração da DVA também foram analisados, tanto por De Luca quanto por Santos ${ }^{135}$, e serão tratados a seguir.

\subsubsection{Vendas de mercadorias, produtos e serviços}

Nesse item, a polêmica é quanto ao conceito de valor adicionado, ou produção versus vendas. Como já ressaltado, para a ciência econômica o valor adicionado é obtido a partir da produção, enquanto na ciência contábil parte-se das vendas realizadas no período, sem se considerar a produção que ainda não foi vendida. Esta segunda abordagem obedece ao Princípio Contábil da Competência do Exercício, onde as receitas, assim como as despesas, devem ser reconhecidas na apuração do resultado do período em que ocorrerem, o que, geralmente, coincide com o momento do faturamento. A vantagem do tratamento do valor adicionado conforme os princípios contábeis utilizados nas demonstrações tradicionais é o aumento da credibilidade dessa demonstração, quando feita a partir das vendas, pela possibilidade de sua reconciliação com a DRE. O modelo desenvolvido pela FIPECAFI, utilizado nesse estudo, não considera a riqueza criada e ainda não repassada a terceiros, ou seja, trabalha com o valor das vendas. Nos modelos de DVA apresentados no capítulo anterior, tanto da Irlanda, quanto da África do Sul, Singapura e Índia, também utilizam-se o valor das vendas.

\footnotetext{
${ }^{135}$ DE LUCA, Márcia Martins Mendes. Demonstração do valor adicionado: do cálculo da riqueza criada pela empresa ao valor do PIB. São Paulo: Atlas, 1998. p. 37-43 e SANTOS, Ariovaldo dos. op .cit. p. 107123.
} 
3.3.3 Provisão para devedores duvidosos - reversão/constituição

Ao deduzir a PDD do item vendas, a empresa está apenas antecipando uma perda que poderá vir a ocorrer no futuro, caso contrário, não constituiria tal provisão. Para fazer frente ao risco, a empresa já o embutiria nos seus preços. Essa é a forma utilizada no modelo desenvolvido pela FIPECAFI, com a PDD como um redutor da receita, sendo que, caso a empresa viesse a receber esses valores sobre os quais foi constituída provisão, evidenciaria o fato como uma recuperação de ativo, no item Perda/recuperação de ativos, quando da reversão da provisão. Nesse momento o risco transforma-se em riqueza. Nas DVAs apresentadas no capítulo 2 não foi observada a evidenciação da PDD.

\subsubsection{Depreciação, amortização e exaustão.}

Aqui, discute-se o tratamento a ser dado à depreciação, amortização e exaustão. Apresentados como elementos componentes da distribuição da riqueza, e demonstrados como valores retidos pela empresa, a exemplo dos lucros retidos, para utilização em futuras reposições dos ativos, como pode ser observado nos modelos de DVAs apresentados no capítulo 2, da Irlanda (Figura 2), de Singapura (Figura 3) e da África do Sul (Figuras 4 e 5). Ou uma segunda alternativa, que é aquela adotada na DVA indiana (Figura 6) e no modelo desenvolvido pela FIPECAFI, onde a depreciação é considerada como redutora do valor adicionado bruto e tratada como um custo "externo", assim como os insumos adquiridos de terceiros, que são diminuídos do valor das vendas. A lógica é que, assim como os custos dos materiais e serviços, os custos dos ativos, representados pela depreciação, amortização e exaustão, devem ser deduzidos da receita durante o período de sua vida útil pois, também são consumidos durante o processo operacional. Esta última modalidade é defendida pelo Prof. Eliseu Martins ${ }^{136}$ :

\footnotetext{
${ }^{136}$ MARTINS, Eliseu. Demonstração do valor adicionado de bancos. IOB Informações objetivas. São Paulo: boletim TC 30/97. p. 4.
} 
"Afinal, a empresa produziu um valor adicionado, mas consumiu uma parte de outro produzido no passado por ela mesma ou por outra empresa. As depreciações, amortizações e exaustões representam baixa de capital acumulado no passado; logo, o que interessa é o valor líquido gerado pela empresa."

A ressalva que se faz a ela é quanto à nomenclatura utilizada no item número 4 , onde são apresentados os valores das depreciações, amortizações e exaustões como Retenções, o que acabaria confundindo o usuário pouco experiente.

\subsubsection{Pessoal e encargos}

Nesse item são lançados os valores pagos aos empregados, referentes à remuneração e aos encargos decorrentes desses pagamentos. Rocha ${ }^{137}$ definiu remuneração: 'É todo e qualquer pagamento efetuado aos empregados em retribuição aos serviços prestados, por força de lei, negociação individual ou coletiva, ou ainda por liberdade do empregador." Para o referido autor, a remuneração compõe-se de três parcelas: a remuneração do tempo à disposição do empregador, como o pagamento pelos serviços efetivamente prestados ou pelo período permanecido à disposição, podendo ser feito por hora, tarefa, e outros; a remuneração complementar, que é o pagamento feito ao empregado sem contraprestação a serviço prestado, como prêmio assiduidade, adicional por horas extras, trabalho noturno e insalubridade; e as ausências remuneradas, que são as obrigações devidas ao empregado relativas a períodos em que ele não tenha permanecido à disposição do empregador, como repouso semanal remunerado, feriados, auxílio-doença, ausências justificadas e previstas na CLT. Pastore ${ }^{138}$ definiu os encargos:

Tratam -se de despesas de caráter obrigatório, decorrentes da constituição e da CLT....

O cálculo dos encargos sociais varia bastante de setor para setor. De um modo geral, eles incluem as despesas com as obrigações sociais (INSS, FGTS, salário-

\footnotetext{
${ }^{137}$ ROCHA, Wellington. Encargos sociais no Brasil antes e depois da Constituição Federal de 1988. Dissertação de mestrado - Faculdade de Economia e Contabilidade da Universidade de São Paulo. São Paulo: FEA/USP, 1991. p. 4-5.

${ }^{138}$ PASTORE, José. Encargos sociais no Brasil: implicações para o salário, emprego e competitividade. São Paulo: LTr, 1997. p. 21-23
} 
educação, etc.) e as despesas referentes à remuneração do tempo não trabalhado (férias, $13^{\circ}$ salário, licenças, abonos, etc.).

Além disso, as empresas costumam incluir no rol dos encargos sociais as obrigações legais que são específicas para cada setor. Há setores que incluem também as despesas que se transformaram em obrigatórias por decorrerem de convenções coletivas que vêm se repetindo há anos."

A observação que se faz é quanto aos valores pagos indiretamente aos empregados, sob a forma de encargos sociais (por exemplo, FGTS).

Esses recursos que são pagos ao governo, e que ficam sob sua custódia, não retornam integralmente aos empregados, sendo utilizados, em parte, pela máquina administrativa para cobrir seus custos, ou que não são utilizados por todos os empregados e nesse caso, não retornam; muitos contam com planos de saúde e de previdência privada. Deveriam, então, ser lançados nesse item? No modelo apresentado, que foi desenvolvido pela FIPECAFI, o valor do FGTS é lançado nesse item, mas o INSS é considerado como uma parcela cujo beneficiário é o governo, o que na realidade o é, pois empresa e empregado contribuem para sustentar um benefício destinado a toda a coletividade e não especificamente a poucos trabalhadores. Senão seria o caso de lançar, também, os outros tributos pagos, como remuneração indireta dos empregados, já que de uma forma ou de outra eles acabam retornando a eles, mesmo que em valores insuficientes e de forma ineficiente. Nas DVAs pesquisadas em outros países, não é possível identificar essa questão.

\subsubsection{Remuneração do capital}

A questão aqui é quanto à transparência da demonstração e sua utilidade informacional. Evidenciar, ou não, a distribuição de riqueza como remuneração do capital, de forma distinta, para os sócios e acionistas - representada pela remuneração do capital próprio sob a forma de dividendos e juros sobre o capital próprio; e os demais financiadores - representada pela remuneração do capital de terceiros sob a forma de juros. 
De Luca, em 1998, afirmou que poucas empresas apresentavam a remuneração de sócios ou acionistas separadamente da dos demais financiadores. Provavelmente esse era o cenário à época pois, essa afirmativa não foi constatada neste estudo, em 2002, como pode ser observado nas DVAs dos diversos países reproduzidas no capítulo 2. Em todas elas, as empresas segregam essa informação. O modelo desenvolvido pela FIPECAFI também. Nada mais correto quando se entende que o objetivo da contabilidade é prestar informações aos seus diversos usuários para a tomada de decisões.

\subsubsection{Receita financeira e receita de equivalência patrimonial}

Esses itens não são originários das operações de produção normal da entidade, ou seja, não são riqueza criada por ela, mas afetam sua riqueza, assim como os aluguéis e juros recebidos.

Se essas receitas forem apenas somadas ao valor das vendas, e consideradas como valor adicionado pela atividade produtiva normal, a avaliação e análise da riqueza total criada pela empresa ficará prejudicada, além de surgir o problema da dupla contagem quando da soma de todos os valores adicionados criados por todas as empresas, para o cálculo do PIB.

É importante, pois, a apresentação desses itens, separadamente, para permitir realmente, avaliar o que é valor adicionado pela atividade produtiva e o que é receita recebida de terceiros. O modelo de DVA desenvolvido pela FIPECAFI, contempla essa distinção, no item 6 , denominada valor adicionado recebido em transferência. Nos modelos de outros países, reproduzidos no capítulo 2, também, pelo menos no que se refere a segregar a receita das vendas das outras receitas. Apenas no demonstrativo da Irlanda (Figura 2) não se observou a presença de itens separados para a classificação das receitas não próprias da atividade produtiva, mesmo porque a empresa mostrada pode não tê-las. 


\subsection{Algumas situações especiais}

\subsubsection{O caso dos bancos}

Conforme visto anteriormente, a distribuição da riqueza é evidenciada na DVA e abrange aqueles que ajudaram a formá-la: os empregados, remunerados pelo emprego de sua força de trabalho; o governo, como apoiador das estruturas que permitem o funcionamento das empresas; e os sócios e financiadores, que são remunerados pelo emprego de seu capital, os primeiros por meio dos lucros e os últimos pelos juros.

Conforme Martins ${ }^{139}$, os juros “...são uma distribuição da renda, uma transferência da riqueza, e não riqueza nova criada. Assim, quem recebe juros (registrados como receitas financeiras, é claro) não está criando riqueza, está recebendo riqueza criada por terceiros."

É o caso dos bancos, que não estão criando riqueza quando recebem juros pelo capital que emprestam a terceiros.Eles recebem apenas parte da riqueza que foi criada por eles e que lhes é transferida.

Esses juros recebidos, por sua vez, são transferidos pelos bancos aos aplicadores pois, na maioria dos casos, eles não trabalham apenas com capital próprio, mas principalmente com capital de terceiros, restando-lhes apenas uma parte dessa riqueza que lhes foi transferida, a remuneração por sua intermediação - captando recursos de quem os tem e transferindo-os a quem necessita.

Nota-se, então, que essas instituições financeiras só criam sua própria riqueza pela prestação efetiva de serviços, e não pelas receitas financeiras que recebem. $\mathrm{Ou}$, como

\footnotetext{
${ }^{139}$ MARTINS, Eliseu. Demonstração do valor adicionado de bancos. IOB informações objetivas. São Paulo: boletim TC 30/97. p. 2.
} 
ressalta Martins ${ }^{140}$, "o valor adicionado dos bancos só existe pelo que eles produzem de serviços aos seus clientes.”

Entretanto, por força de uma convenção internacional ${ }^{141}$, é admitido para as instituições financeiras que as receitas financeiras recebidas como transferência de terceiros não sejam consideradas como tal, e sim como geradoras de valor adicionado; e as despesas financeiras como redutoras dessa receita gerando, assim, o valor adicionado dos bancos, juntamente com suas receitas de prestação de serviços.

Cabe ressaltar que, como foi atribuído à instituição financeira um valor adicionado que na realidade ela não gerou, deverá aqui ser feita uma eliminação quando do cálculo do PIB, para não se cair no problema da dupla contagem.

\subsubsection{Empresas com prejuízos contábeis e/ou valor adicionado negativo}

Até agora, limitou-se a tratar a DVA como uma demonstração que evidencia a criação de riqueza pela empresa e sua distribuição aos diversos agentes econômicos. Essa situação, porém, nem sempre é a única possível.

Muitas empresas trabalham com outras duas situações, que foram salientadas e demonstradas por Santos e Parmezzano ${ }^{142}$, e que são atípicas ao que até agora se tratou.

A primeira delas é aquela onde a empresa apresenta prejuízo contábil na DRE mas que, na elaboração da DVA, apresenta geração de valor adicionado suficiente para remunerar seus empregados, governo, e financiadores externos de capital. Nesse caso, sua riqueza criada não foi suficiente apenas para remunerar seus sócios/acionistas, que arcam, assim, com o prejuízo verificado.

\footnotetext{
140 op. cit. p. 2.

${ }^{141}$ MARTINS, Eliseu. op. cit. p. 3

${ }^{142}$ SANTOS, Ariovaldo dos. PARMEZZANO, Cláudia Meca. Valor adicionado negativo - É possível? IOB informações objetivas. São Paulo: boletim TC 49/99. p. 6-11.
} 
A outra situação é aquela em que os autores demonstram ser possível a empresa apresentar valor adicionado negativo. Isso significa que os recursos consumidos pela empresa não foram todos gerados por ela, uma parte foi oriundo de capital de terceiros. Dessa forma, o valor adicionado criado não foi suficiente para cobrir a riqueza distribuída para os diversos agentes econômicos. 


\section{CAPÍTULO 4 - PLANEJAMENTO E COLETA DOS DADOS}

\subsection{Introdução}

Para que haja uma correta compreensão da metodologia e dos resultados da pesquisa empírica realizada, torna-se necessária a definição conceitual e a caracterização de população, ou universo, e amostra.

Segundo Martins ${ }^{143}$, 'O conceito de população é intuitivo; trata -se do conjunto de indivíduos ou objetos que apresentam em comum determinadas características definidas para o estudo". Assim, há que existir pelo menos uma variável comum entre eles, passível de observação.

Conhecer precisamente a população pesquisada requer o estudo de todos os seus elementos. Mas nem sempre é possível, ou desejável, obter informações de todos eles, seja por limitações de tempo, custo, ou simplesmente pela falta delas. Nesse momento utiliza-se da amostra que, conforme observam Bussab e Morettin ${ }^{144}$ “..é qualquer subconjunto da população”.

Stevenson ${ }^{145}$ salientou a peculiaridade que torna um conjunto, ora amostra, ora população:

'Os termos população e amostra se referem a um conjunto específico de circunstâncias. Ou seja, em determinado caso os alunos de uma sala de aula podem ser considerados como uma população, da qual iremos extrair amostras para

\footnotetext{
${ }^{143}$ MARTINS, Gilberto de Andrade. Manual para elaboração de monografias e dissertações. 2. ed. São Paulo: Atlas, 2000. p. 35

${ }^{144}$ BUSSAB, Wilton O. MORETTIN, Pedro A. Estatística básica. 4. ed. São Paulo: Atual, 1987. p. 182

${ }^{145}$ STEVENSON, Willian J. Estatística aplicada à administração. São Paulo: Harbra, 1981. p. 159.
} 
análise. Já em outra situação, aqueles mesmos alunos podem ser considerados como uma amostra de todos os alunos do colégio, ou de toda a universidade”.

Cabe ao investigador cercar-se de cuidados para a obtenção de uma amostra significativa, e que represente de maneira objetiva a população.Conforme ressalta Martins $^{146}$, existem dois métodos, basicamente, para composição da amostra: o método probabilístico e o não probabilístico.

'O método de amostragem probabilística exige que cada elemento da população possua determinada probabilidade de ser selecionado. (...) Trata-se do método que garante cientificamente a aplicação das técnicas estatísticas de inferência. Somente com base em amostragens probabilísticas é que se podem realizar inferências ou induções sobre a população a partir do conhecimento da amostra".

Os métodos não probabilísticos, 'São amostragens em que há uma escolha deliberada dos elementos da amostra. Não é possível generalizar os resultados das pesquisas para a população, pois as amostras não-probabilísticas não garantem a representatividade da população”.

A população e amostra da pesquisa realizada serão definidas e caracterizadas a seguir.

\subsection{Definição e Caracterização da População}

No Brasil, a elaboração e publicação da DVA ainda não é obrigatória. As empresas que a elaboram e publicam, o fazem de forma espontânea. Algumas instituições apoiam e incentivam essa iniciativa.

A Fundação Instituto de Pesquisas Contábeis, Atuariais e Financeiras FIPECAFI $^{147}$, órgão de apoio institucional ao Departamento de Contabilidade e Atuária da Faculdade de Economia, Administração e Contabilidade da Universidade de São Paulo - FEA/USP, mantém um cadastro próprio de empresas, formado por

\footnotetext{
${ }^{146}$ MARTINS, Gilberto de Andrade. Manual para elaboração de monografias e dissertações. 2. ed. São Paulo: Atlas, 2000. p. 38-40.

${ }^{147}$ As informações referentes ao banco de dados da FIPECAFI foram fornecidas por meio de entrevista concedida por Nivaldo Gomes Lamac, analista de sistemas da referida fundação, realizada em 03/04/02.
} 
aproximadamente 3.300 empresas ${ }^{148}$ com atuação em todas as áreas econômicas do território nacional. Esse cadastro é abastecido por informações obtidas a partir das demonstrações contábeis publicadas em jornais de diversas Unidades Federativas ou enviadas espontaneamente, e também por outras informações, obtidas por meio de questionários específicos e dirigidos às empresas, estas últimas não disponíveis ao público em geral. Esse cadastro é a principal base de dados usada na edição anual de Melhores e Maiores - MM, da Revista Exame.

Para o ano de 1998, os professores L. Nelson Carvalho e Ariovaldo dos Santos, do Departamento de Contabilidade e Atuária da Faculdade de Economia, Administração e Contabilidade da Universidade de São Paulo - FEA/USP, e responsáveis pela edição de MM, conforme dito anteriormente, decidiram incluir na publicação dados relativos à DVA. A FIPECAFI elaborou um modelo próprio do demonstrativo, já apresentado nesse trabalho, distribuindo-o, acompanhado das instruções de preenchimento, às empresas que figuraram nas edições da MM a partir de 1996.

Logo após, decidiu-se por incluir o índice "Valor Adicionado por Empregado", em substituição a "Vendas por Empregado", no cálculo da "excelência empresarial" conjunto de índices utilizado para a escolha das Melhores e Maiores empresas.

Foram recebidas 505 DVAs relativas ao ano de 1996, 687 ao ano de 1997, 827 ao ano de 1998, 940 ao ano de 1999, e 1073 ao ano de 2000. Das empresas que enviaram suas demonstrações para o cadastro da FIPECAFI, apenas 34 as publicaram referente ao ano de 2000, 33 ao ano de 1999, 17 ao ano de 1998, e 13 ao ano de 1997, sendo que essa informação não se encontra disponível para 1996.

O universo representado pelas empresas que enviaram suas DVAs referentes aos anos de 1996 à 2000 constituiu-se na população escolhida para esta pesquisa.

${ }^{148}$ No dia 03/04/02 o número era de 3323 empresas. 


\subsection{Amostragem}

A composição da amostra foi elaborada pelo método não probabilístico, sendo usada a amostragem intencional. Esse tipo de amostragem é definido por Martins ${ }^{149}$; “de acordo com determinado critério, é escolhido intencionalmente um grupo de elementos que irão compor a amostra".

Norteou a composição da amostra o fato da empresa ter, sistematicamente, enviado sua DVA para o cadastro da FIPECAFI, ao longo de todo o período sob análise.

O grupo de elementos que compõem a amostra foi formado por aquelas empresas que enviaram suas DVAs à Revista Exame, para a edição de MM, em todos os anos do período escolhido para a análise, de 1996 a 2000, totalizando 198 empresas. A limitação do período escolhido para análise é assim explicada: 1) definiu-se pelo ano de 1996, por ser esse o primeiro a contar com as informações sobre DVA necessárias à análise; 2) o ano de 2000 foi escolhido por ser o último em que as informações se encontravam disponíveis. As informações referentes ao ano de 2001 serão publicadas na edição de MM de 2002 e, no momento em que esse estudo estava sendo realizado, os dados ainda estavam sendo coletados e tabulados. Portanto, optou-se por analisar todo o período em que as informações se encontravam disponíveis.

Razões ligadas à possibilidade de comparação nos diversos anos justificam a escolha de empresas que entregaram suas demonstrações em todos os anos do período escolhido para a análise.

O fato de se optar pelo método não-probabilístico deveu-se a diversas razões, dentre elas:

- não excluir do estudo alguma empresa que pudesse ser representativa da sua atividade ou setor;

- o pequeno número de pesquisas existentes com a mesma finalidade;

\footnotetext{
${ }^{149}$ MARTINS, Gilberto de Andrade. Manual para elaboração de monografias e dissertações. 2. ed. São Paulo: Atlas, 2000. p. 41.
} 
- entender-se que seria importante analisar todo o material que se encontrava disponível, levando-se em conta que ele é restrito, já que a demonstração não é obrigatória.

A amostra foi formada por 198 empresas, das mais diversas regiões, setores e ramos de atividade, conforme será apresentado a seguir.

\subsection{Caracterização da Amostra}

As 198 empresas incluídas nesta pesquisa estão classificadas da mesma forma utilizada para a elaboração de MM. Estão distribuídas em 3 grandes ramos de atividade: indústria, comércio e serviços; e em 25 setores descritos a seguir:

- alimentos - fabricantes de produtos alimentícios, frigoríficos, laticínios, etc.;

- atacado e comércio exterior - trading companies, atacadistas, distribuidoras de combustíveis, cooperativas de produtores, etc.;

- automotivo - montadoras de automóveis e caminhões, fabricantes de tratores e máquinas agrícolas, fabricantes de carrocerias, fornecedores de autopeças e componentes, etc.;

- bebidas - cervejarias, fabricantes de refrigerantes;

- comércio varejista - supermercados, redes de lojas de eletrodomésticos, vestuário e calçados, distribuidores de GLP, revendedores de veículos, etc.;

- comunicações - revistas, jornais, redes de televisão, etc.;

- confecções e têxteis - fabricantes de tecidos, de peças de vestuário, de calçados, de lingerie, de fios têxteis, etc.;

- construção - empreiteiras de construção pesada, construção civil, empresas de montagem industrial, de projetos de engenharia, etc.;

- diversos - aquelas com atividade diversificada ou que não disponham de classificação específica;

- eletroeletrônicos - fabricantes de aparelhos eletroeletrônicos (televisores, videocassetes, rádios etc.), fabricantes da linha branca (geladeiras, máquinas 
de lavar, etc.), fabricantes de equipamentos de telefonia, fabricantes de cabo, etc.;

- farmacêutico - laboratórios farmacêuticos;

- fumo - fabricantes de cigarro, cigarrilhas, etc.;

- higiene, limpeza e cosméticos - fabricantes de produtos de higiene pessoal (sabonetes, dentifrícios etc.), de perfumes e produtos de beleza, de material de limpeza, etc.;

- material de construção - fabricantes de cimento, de vidro, de tubos e conexões, de cerâmicas, de revestimentos e forro, etc.;

- mecânica - fabricantes de bens de capital seriados e não seriados (motores, turbinas, tubos, máquinas operatrizes, elevadores, pontes rolantes, etc.);

- mineração - empresas mineradoras;

- papel e celulose - fabricantes de papel e celulose;

- plásticos e borrachas - fabricantes de pneus e artefatos de borracha, embalagens e utensílios de plástico, etc.;

- química e petroquímica - companhias petrolíferas, refinarias, centrais de matérias-primas;

- serviços de transporte - companhias de transporte aéreo, empresas de transporte rodoviário de passageiros e de carga, companhias de cabotagem e navegação marítima, serviços de courier, transporte de valores, transporte ferroviário de passageiros e carga, de logística, locadoras de veículos, etc.;

- serviços diversos - hospitais, empresas de assistência médica, administradora de cartões de crédito, hotéis, administradoras de vales-refeição, empresas de refeições industriais, etc.;

- serviços públicos - correios, concessionárias de energia elétrica, de abastecimento de água e gás, de administração portuária, de rodovias e pontes, dos serviços de tráfego aéreo, etc.;

- siderurgia e metalurgia - siderúrgicas, metalúrgicas, fabricantes de dutos, produtoras de alumínio, etc.;

- tecnologia e computação - fabricantes de computadores e periféricos, de sistemas de automação bancária, produtores de software, etc.;

- telecomunicações - operadoras de telefonia fixa e móvel. 
Especificamente no ano de 2000, das empresas da amostra, 26 eram estatais consideradas aquelas em que o poder público (seja municipal, estadual ou federal), direta ou indiretamente, é o acionista controlador; e 172 eram empresas da iniciativa privada. Além disso, apenas 6 empresas, das 198 selecionadas, publicaram suas DVAs, sistematicamente, referentes aos anos de 1997 a 2000. São elas: COPEL, CEEE, CEMIG, CESP, FURNAS e CEB, empresas de serviços públicos sediadas no Paraná, no Rio Grande do Sul, Minas Gerais, São Paulo, Rio de Janeiro e Brasília respectivamente.

A relação das empresas com os principais dados que serviram de embasamento ao trabalho, consta do Apêndice A.

\subsection{Tratamento dos Dados}

Os valores dos demonstrativos apresentados nesta pesquisa estão expressos em moeda do dia 31 de dezembro de 2000 , sendo que a paridade utilizada para a transformação foi de R\$1,9554 para cada US\$1.00. Antes de serem convertidos para dólar, os valores referentes a pessoal e encargos, impostos, taxas e contribuições, juros e aluguéis e receita operacional bruta, foram atualizados pela taxa do IGP-M - Índice Geral de Preços de Mercado, da Fundação Getúlio Vargas até o último dia de cada ano. Exceção foi feita às empresas que apresentaram sua DVA em moeda de poder aquisitivo constante.

O número de empregados refere-se ao existente no último dia de cada um dos anos, e o número médio de empregados foi obtido pela média aritmética do número de empregados existentes no início e no final de cada ano, razão pela qual não há número médio de empregados para o ano de 1996 (não existem dados de 1995).

Os dados passaram por um tratamento estatístico de análise descritiva, sendo calculados média, mediana e desvio padrão. As tabelas e quadros com a análise descritiva se encontram no Apêndice A. Para efeito de análise, as empresas foram agrupadas por setor, ramo de atividade, região geográfica e distribuição de riqueza. 


\section{CAPÍTULO 5 - ANÁLISE DOS RESULTADOS}

\subsection{Introdução}

Conforme já se mencionou as informações obtidas junto ao cadastro da FIPECAFI constituíram a amostra desta pesquisa. Tratam-se de 198 empresas que apresentaram suas DVAs, sistematicamente, nos anos de 1996 a 2000. Após distribuição e tratamento estatístico, os dados serão analisados a seguir.

Antes, porém, algumas considerações tornam-se necessárias. A análise que ora se procederá tem pretensões apenas descritivas e exploratórias, não servindo as constatações encontradas na amostra para realizar qualquer inferência relativa à população. Isto se deve principalmente ao fato de tratar-se de amostra não probabilística. Além disso, cabe ressaltar que o estudo realizado pode ter sofrido algum viés, posto que a amostra é diversificada, apresentando empresas com dados bastante diferentes. Como exemplo, o caso da Petrobrás, uma das empresas participantes, que sozinha detém mais de $22 \%$ de todo o valor adicionado da amostra, em todo o período analisado. Mesmo assim, optou-se por analisar o conjunto, devido à grande oportunidade de análise de uma demonstração cuja elaboração é opcional e vem crescendo significativamente, nos últimos 5 anos.

Cabe ressaltar, ainda, que variáveis como: condições do mercado de trabalho, características próprias dos setores e ramos de atividade, terceirizações, medidas governamentais e outras, podem ter influenciado os índices adotados, principalmente o valor adicionado distribuído por empregado. Estas influências serão ressaltadas quando de sua ocorrência. 


\subsection{Análise Geral}

A amostra foi agrupada por ramos de atividade e por setores. Segundo o ramo de atividade, foram encontradas e analisadas 21 empresas comerciais, representando $10,6 \%$ do total da amostra, 122 empresas industriais, ou 61,6\%, e 55 empresas prestadoras de serviço, $27,8 \%$.

Das empresas comerciais, 11 pertencem ao setor de atacado e comércio exterior e 10 ao de comércio varejista.

As empresas industriais foram distribuídas pelos setores de: alimentos (17), automotivo (8), bebidas (3), confecções e têxteis (17), construção (5), diversos (2), eletroeletrônicos (7), farmacêutico (4), fumo (1), higiene, limpeza e cosméticos (3), material de construção (8), mecânica (6), mineração (7), papel e celulose (9), plásticos e borracha (2), química e petroquímica (9), e siderurgia e metalurgia (14).

As empresas prestadoras de serviço foram divididas entre os setores de comunicação, serviços de transporte, serviços diversos, serviços públicos, tecnologia e computação, e telecomunicações com 1, 13, 5, 27, 7 e 2 empresas, respectivamente.

O montante do valor adicionado das 198 empresas, expresso em moeda do dia 31 de dezembro de 2000, no ano de 1996, foi de 43,73 bilhões de dólares. Em 1997, 47,13 bilhões de dólares. Em 1998, montou 46,3 bilhões de dólares. Para 1999, foi de 52,95 bilhões de dólares. Em 2000, o valor adicionado total chegou a 54,44 bilhões de dólares. Portanto, um aumento de $24,49 \%$ no período, observando-se, contudo, uma ligeira queda em 1998, em relação a 1997, de 1,76\%. A distribuição aos agentes que contribuíram para a formação do valor adicionado estão nos Gráficos 1 a 5. 


\section{Gráfico 1- Distribuição do valor adicionado em 1996}

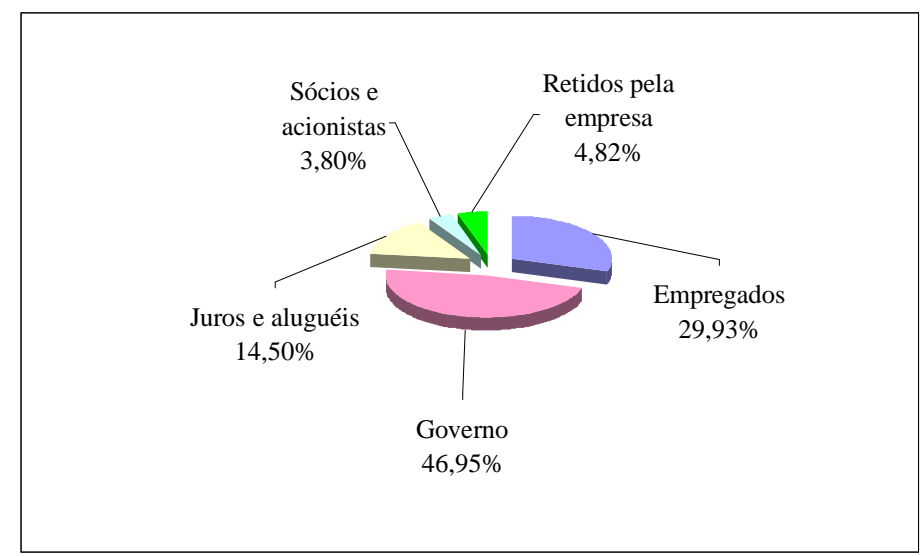

No ano de 1996 o governo ocupou o primeiro lugar na distribuição do valor adicionado e os empregados o segundo. Os sócios e acionistas ficaram com a menor de todas as parcelas.

\section{Gráfico 2 - Distribuição do valor adicionado em 1997}

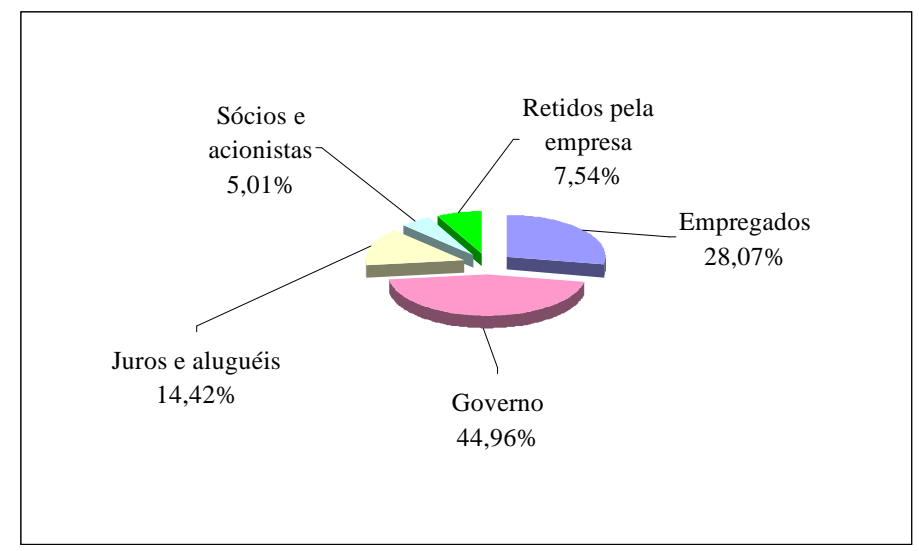

Em 1997 a situação manteve-se a mesma de 1996, com governo, empregados e sócios e acionistas ocupando o primeiro, segundo e último dos lugares, respectivamente. Entretanto, observou-se ligeira queda percentual tanto na distribuição ao governo quanto aos empregados. A participação de sócios e acionistas, contudo, cresceu $31,84 \%$. 


\section{Gráfico 3 - Distribuição do valor adicionado em 1998}

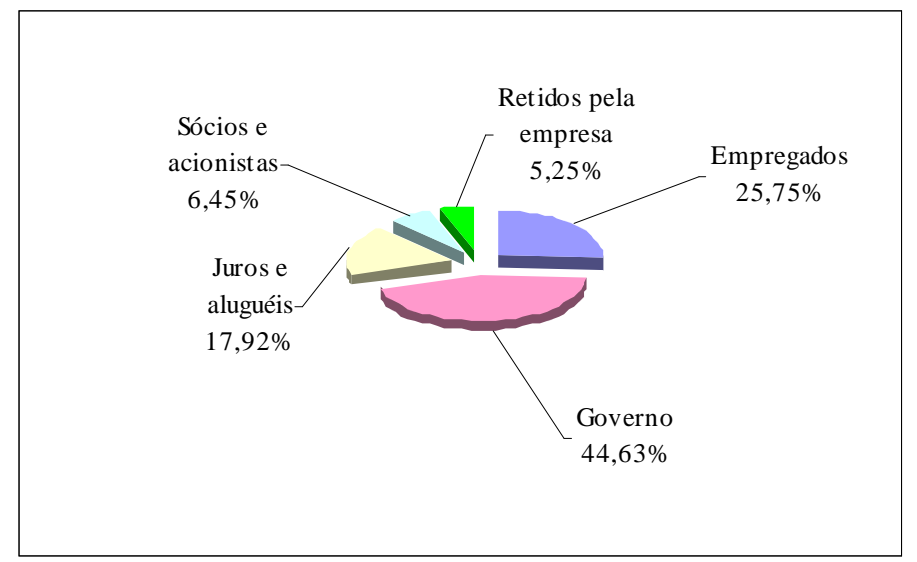

No ano de 1998 as posições de governo e empregados continuaram inalteradas, ainda em ligeiro declínio percentual. Contudo, a parcela retida pelas empresas passou a ocupar o último lugar.

\section{Gráfico 4 - Distribuição do valor adicionado em 1999}

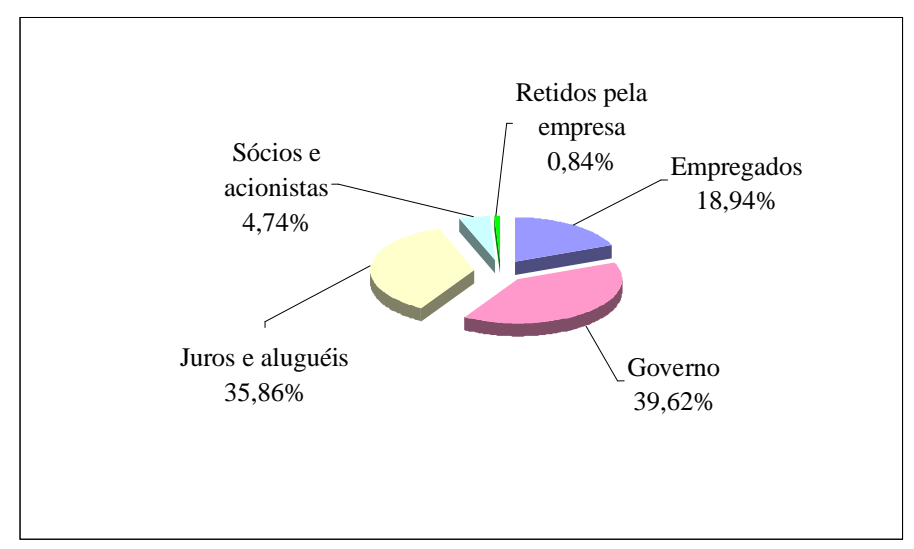

A situação em 1999 é outra. O governo continuou ocupando a primeira posição, ainda com decréscimo percentual. Contudo, a segunda maior distribuição passou a ser para juros e aluguéis, influência da variação cambial ocorrida no $1^{\circ}$. Trimestre desse ano e que será comentada a seguir. Os valores retidos pelas empresas ocuparam novamente o último lugar. 
Gráfico 5 - Distribuição do valor adicionado em 2000

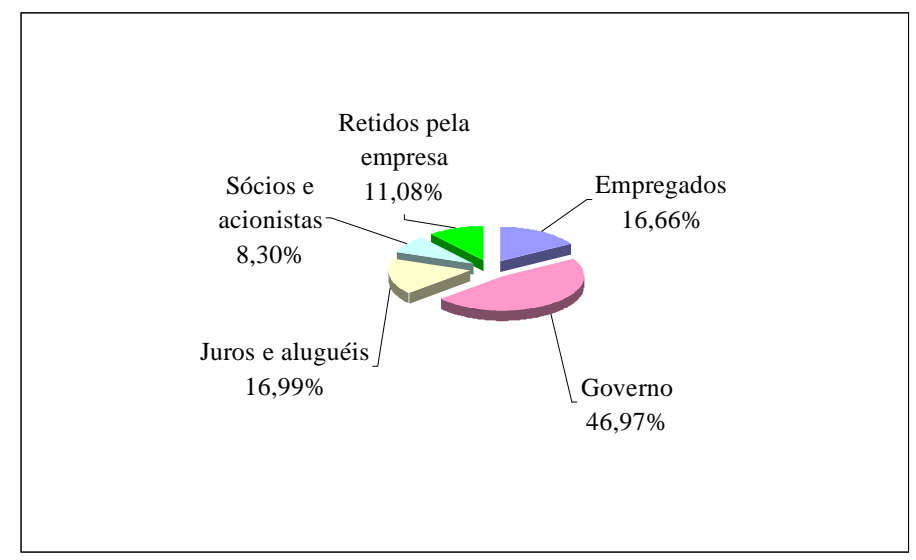

O ano de 2000 manteve inalterados primeiro e segundo lugares observados em 1999 mas, o percentual distribuído a empregados (terceiro lugar na distribuição), já se apresenta semelhante ao de juros e aluguéis.

O número médio de empregados das empresas da amostra em cada ano está no Gráfico 6. Esta média foi encontrada tomando-se por base o número de empregados existentes no início e no final do período. Entende-se, por início do período, o registro existente no último dia do período imediatamente anterior. Conforme já dito, esta é a razão para a não existência deste dado para o ano de 1996. Verifica-se um decréscimo crescente, que atingiu 7,41\%, com pequeno retrocesso em 2000.

\section{Gráfico 6 - Número médio de empregados de 1997 a 2000}

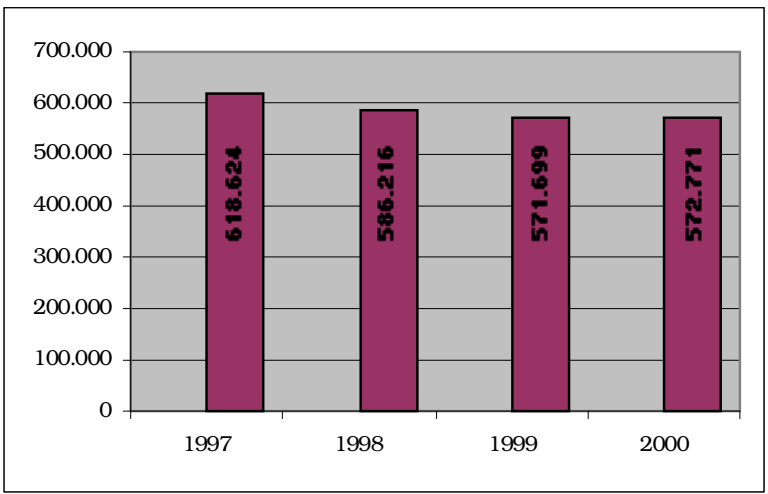


O valor agregado distribuído por empregado foi obtido dividindo-se, a cada ano, o valor distribuído para pessoal e encargos, pelo número médio de empregados.

Volta-se a ressaltar que variáveis como: condições do mercado de trabalho, características próprias dos setores e ramos de atividade, terceirizações, medidas governamentais e outras, podem ter influenciado o valor adicionado distribuído por empregado. Entretanto, como o objetivo desta pesquisa é considerar as informações prestadas na DVA para avaliar a variação da riqueza das empresas e a variação da remuneração dos empregados, e por tratar-se de estudo da área contábil, optou-se por sua utilização, entendendo tratar-se do melhor avaliador para as variáveis estudadas, no âmbito da contabilidade. Os valores estão demonstrados no Gráfico 7.

Gráfico 7 - Valor agregado por empregado de 1997 a 2000

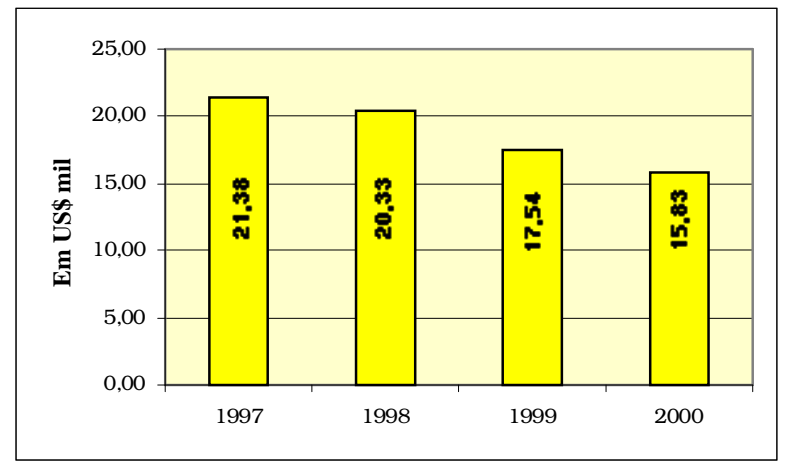

Em 1997, cada empregado ficou com 21,38 milhares de dólares; em 1998 com 20,33 milhares; em 1999, com 17,54 milhares; e em 2000, com 15,83 milhares. Observouse um comportamento em constante declínio, registrando-se uma redução de 25,96\%.

As principais informações se encontram reunidas na Tabela 7. 
Tabela 7- Informações Gerais

\begin{tabular}{|c|c|c|c|c|c|}
\hline \multirow{2}{*}{ Informação } & \multicolumn{5}{|c|}{ Ano } \\
\hline & 1996 & 1997 & 1998 & 1999 & 2000 \\
\hline VA gerado (em US\$ mil) & 43.728 .356 & 47.126 .305 & 46.300 .229 & 52.948 .073 & 54.443 .977 \\
\hline Participação \% do VA no PIB & 7,58 & 7,87 & 7,50 & 9,77 & 9,80 \\
\hline Participação \% do VA na receita & 46,59 & 48,99 & 49,20 & 51,46 & 48,12 \\
\hline \multicolumn{6}{|l|}{ Distribuição do VA } \\
\hline Pessoal e encargos (em US\$ mil) & 13.092 .075 & 13.226 .438 & 11.915 .481 & 10.026 .274 & 9.067 .685 \\
\hline \% no VA total & 29,93 & 28,07 & 25,74 & 18,94 & 16,66 \\
\hline Impostos, taxas e con tribuições (em US\$ mil) & 20.531 .854 & 21.188 .195 & 20.664 .772 & 20.977 .612 & 25.570 .609 \\
\hline \% no VA total & 46,95 & 44,96 & 44,63 & 39,62 & 46,97 \\
\hline Juros e aluguéis (em US\$ mil) & 6.339 .332 & 6.797 .655 & 8.297 .867 & 18.986 .415 & 9.249 .146 \\
\hline \% no VA total & 14,50 & 14,42 & 17,92 & 35,86 & 16,99 \\
\hline JCP e dividendos (em US\$ mil) & 1.657 .355 & 2.362 .833 & 2.987 .931 & 2.509 .336 & 4.521 .639 \\
\hline \% no VA total & 3,80 & 5,01 & 6,45 & 4,74 & 8,30 \\
\hline Lucros/prejuízos retidos (em US\$ mil) & 2.107 .740 & 3.551 .184 & 2.434 .178 & 448.436 & 6.034 .898 \\
\hline$\%$ no VA total & 4,82 & 7,54 & 5,25 & 0,84 & 11,08 \\
\hline Número médio de empregados & & 618.624 & 586.216 & 571.699 & 572.771 \\
\hline VA por empregado (em US\$ mil) & & 21,38 & 20,33 & 17,54 & 15,83 \\
\hline
\end{tabular}

Pela observação da Tabela 7, algumas considerações tornam-se possíveis.

O montante de riqueza criada pela amostra de empresas apresenta-se ascendente, exceto por uma queda de 1,75\% observada no ano de 1998, em relação ao ano anterior. Mantém-se, neste caso, a mesma tendência de crescimento observada pelo Prof. Dr. Ariovaldo dos Santos, em sua tese de livre docência ${ }^{150}$ em 1999, com dados de 1996 e 1997. O mesmo comportamento é mantido pela participação percentual do valor adicionado sobre a receita operacional bruta.

\footnotetext{
${ }^{150}$ SANTOS, Ariovaldo dos. Demonstração contábil do valor adicionado- DVA- Um instrumento para medição da geração e distribuição de riqueza das empresas. Tese de Livre Docência - Faculdade de Economia e Contabilidade da Universidade de São Paulo. São Paulo: FEA/USP, 1999, p.201.
} 
A mesma constatação não pode ser feita com relação a pessoal e encargos, onde o valor distribuído cai 30,74\% durante o período analisado, passando de 13,1 bilhões de dólares em 1996 para 9,1 bilhões em 2000. Decresce, portanto, a participação percentual dos recursos distribuídos aos empregados no valor adicionado total.

Além da queda no montante e no percentual distribuídos aos empregados, é decrescente, também, o número médio de pessoas empregadas nessas empresas, ao longo dos anos, representando 45.853 (7,5\%) postos de trabalho a menos em 2000 que em 1997, conforme ficou evidenciado no Gráfico 6.

Observou-se, também, uma redução sistemática no valor adicionado distribuído a cada empregado. O valor reduziu de 21,38 milhares de dólares em 1996 para 15,83 milhares em 2000 (redução de quase 26\%), como foi demonstrado no Gráfico 7.

Certamente, essa diminuição sistemática de postos de trabalho e redução drástica de remuneração justifica a situação apresentada no item 2.3.3 sobre a distribuição de renda no Brasil. Com a classe trabalhadora recebendo cada vez menos, a tendência é que a concentração de renda e a pobreza se mantenham constantes, na melhor das hipóteses.

No país, a renda média familiar per capita de $40 \%$ da população considerada mais pobre não ultrapassa 1.200 reais (esse valor foi obtido por meio da informação constante na Tabela 4 do capítulo 2, onde, em 1999, os $40 \%$ mais pobres da população recebiam 0,5 salário mínimo ao mês. $\mathrm{O}$ valor do salário mínimo atual abril de 2002 - é de R\$ 200,00. Durante um ano são 6 salários mínimos, que equivalem a $\mathrm{R} \$ 1.200,00)$. O valor adicionado por empregado das empresas da amostra obtido nesta pesquisa é de quase $\mathrm{R} \$ 41.500,00^{151}$ (17,54 ${ }^{152}$ milhares de dólares). Vista desta forma, essa relação é absurda, chegando a ser indecente, pois, a parte mais pobre da população aufere um ganho quase 40 vezes menor do que aquele percebido pelos trabalhadores das grandes empresas que foram foco dessa pesquisa.

\footnotetext{
${ }^{151}$ Pela cotação do dólar de 30/04/2002 de R \$ 2,365 para cada US\$ 1,00.

${ }^{152}$ Valor agregado por empregado das empresas da amostra em 1999, conforme Tabela 7.
} 
A participação percentual dos recursos destinados ao governo (por meio do pagamento de impostos, taxas e contribuições) no valor adicionado total, sofreu pouca oscilação no período analisado. Mas, ressalte-se que o governo é o agente que mais absorveu recursos. A maior oscilação foi verificada no ano de 1999, em torno de $11 \%$ em relação a 1998 . O valor agregado durante todo o período apresentou crescimento de $24,49 \%$.

Nesse mesmo ano a participação percentual de juros e aluguéis sofreu um salto de mais de 100\%, passando de 17,92\% em 1998 para 35,86\% em 1999, e despencando para 16,99\% (mais de 50\%) no ano seguinte. Os valores em dólares tiveram o mesmo comportamento. Situação contrária foi verificada pelo Prof. Ariovaldo dos Santos ${ }^{153}$ nos seus estudos de 1999, com dados de 1996 e 1997.

A justificativa para uma oscilação tão significativa na distribuição para juros e aluguéis é encontrada na variação cambial ocorrida no $1^{\circ}$. Trimestre de 1999.

Embora em 25/03/99 a Medida Provisória 1818/99, tenha autorizado as pessoas jurídicas a registrarem em conta do ativo diferido, o resultado líquido negativo decorrente do ajuste dos valores em reais de obrigações e créditos, feito em razão da variação nas taxas de câmbio ocorrida no primeiro trimestre de 1999, permitindo que o valor da despesa registrado como ativo fosse amortizado ao longo de 4 anoscalendário, a partir da data do diferimento, a FIPECAFI, ao receber as demonstrações e informações contábeis referentes a esse período, ajustou o resultado das empresas de seu cadastro, lançando toda esta variação cambial no resultado das mesmas, e reconhecendo integralmente o efeito negativo em 1999. Essa ação foi realizada com o intuito de não ferir os princípios contábeis, que determinam que as perdas e os ganhos cambiais decorrentes da flutuação da moeda nacional em relação a moedas estrangeiras devem ser, como regra geral, reconhecidos como despesa ou receita, pelo regime de competência, com base nas taxas de câmbio em vigor na data de

153 op. cit. p. 201 
encerramento do balanço. Além de permitir a comparabilidade de dados entre as diversas empresas, já que nem todas optaram pela contabilização do diferido.

O impacto gerado no resultado das empresas foi responsável, também, pela queda significativa ocorrida nesse mesmo ano, nos valores distribuídos aos sócios e acionistas e nos valores retidos por elas.

Constata-se pela análise das informações uma queda acentuada na distribuição para os empregados, e em contrapartida, um aumento na distribuição aos sócios e acionistas, juros e aluguéis e na retenção pelas empresas. A distribuição ao governo manteve-se constante.

\subsection{Análise por Ramos de Atividade}

As empresas da amostra foram agrupadas pelos 3 ramos de atividade, conforme Gráfico 8.

\section{Gráfico 8 - Distribuição da amostra por ramos de atividade}

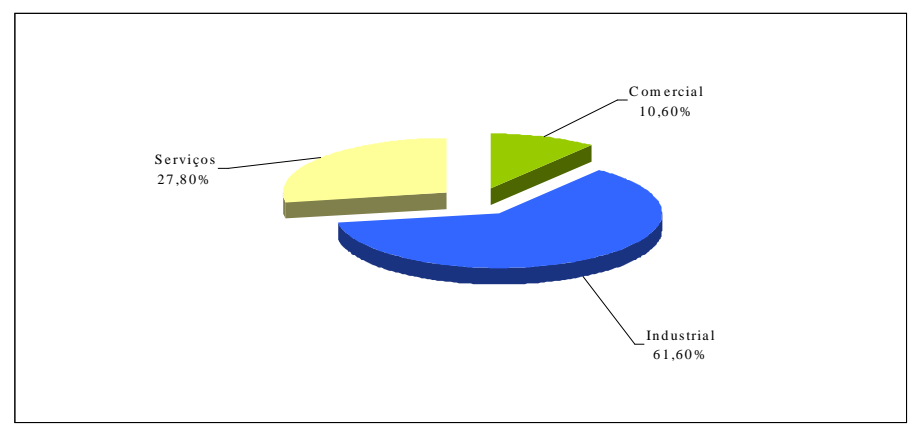

Nota-se que o ramo predominante é o industrial e o menos representativo é o comercial.

O valor adicionado pelas empresas da amostra de acordo com o ramo de atividade a que pertencem, em 1996, ficou distribuído conforme demonstrado no Gráfico 9. 
Gráfico 9 - Valor adicionado pelas empresas da amostra em 1996

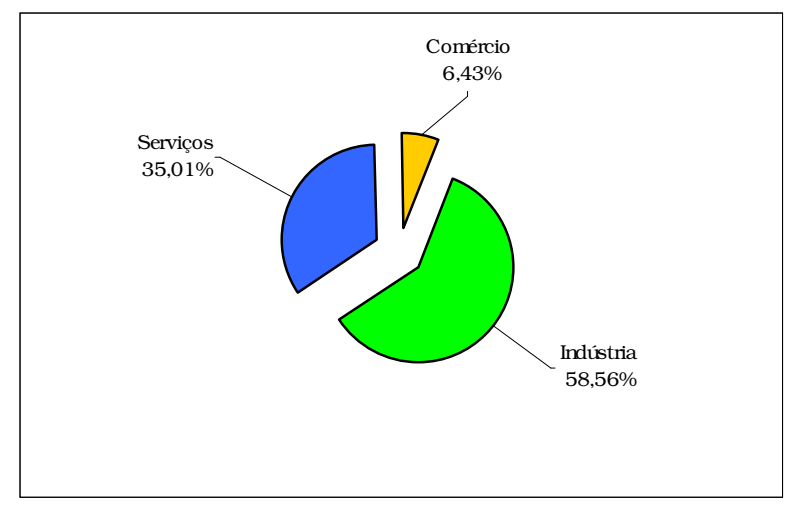

Em 1996, o ramo comercial foi responsável pela geração de um valor adicionado de 2,81 bilhões de dólares, ou 6,43\% de todo o valor adicionado gerado pela amostra. Uma das empresas participantes desse ramo de atividade, a Petrobrás Distribuidora, figurou entre as 11 empresas que mais geraram valor adicionado na amostra, 2,48\% do total ou 1,08 bilhões $-38,43 \%$ de todo o valor gerado pelo ramo.

A participação dos agentes na distribuição se encontra no Gráfico 10.

\section{Gráfico 10 - Distribuição do valor adicionado em 1996 - Comércio}

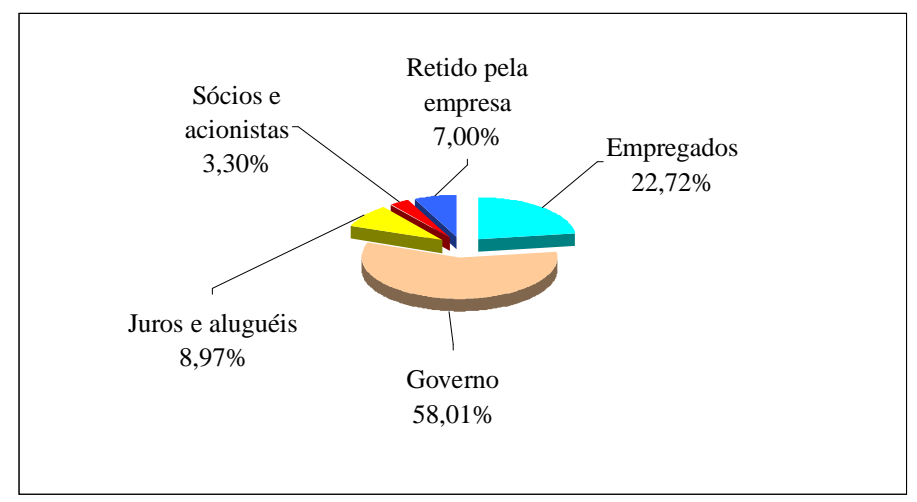

$\mathrm{O}$ agente que mais absorveu recursos foi o governo (mais de 50\%), acompanhado de empregados. O que menos absorveu entre todos foram sócios e acionistas. 
A indústria gerou 25,61 bilhões de dólares ou 58,56\% do total, distribuídos conforme o Gráfico 11.

\section{Gráfico 11 - Distribuição do valor adicionado em 1996 - Indústria}

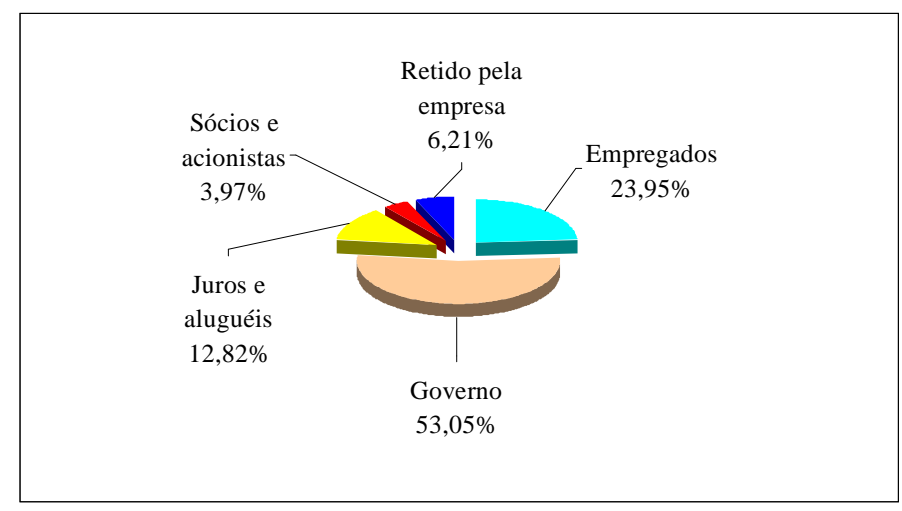

Observa-se que os agentes ocupam a mesma colocação na distribuição do valor adicionado observada no comércio.

Serviços criou os outros $35,01 \%$ de riqueza, ou 15,3 bilhões de dólares, distribuídos para os agentes conforme Gráfico 12. As prestadoras de serviço ocuparam 6 dos 10 primeiros lugares referentes às maiores geradoras de riqueza, com 8,84 bilhões, que representam $20,2 \%$ da amostra e $57,78 \%$ do ramo.

\section{Gráfico 12 - Distribuição do valor adicionado em 1996 - Serviços}

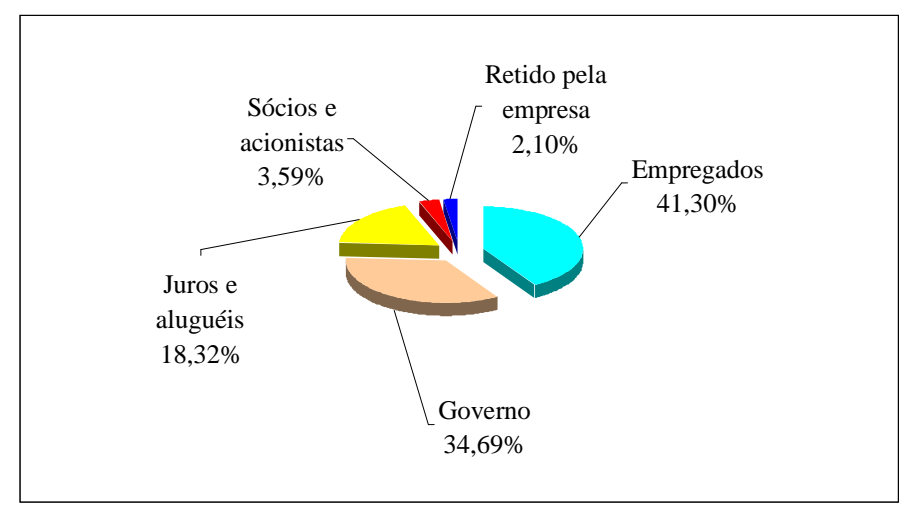

Aqui as posições se invertem. Os empregados consumiram mais recursos que o governo, e o percentual retido pelas empresas ocupa o último lugar. Constatou-se que 
3 empresas geraram valor adicionado negativo nesse ano, sendo 2 industriais e 1 prestadora de serviços.

O valor adicionado pelas empresas da amostra, no ano de 1997, teve a configuração apresentada no Gráfico 13. Nesse ano, o ramo comercial gerou 5,5\% da riqueza, o industrial $57,52 \%$, e o de serviços $36,98 \%$, 2,59 bilhões, 27,11 bilhões e 17,43 bilhões de dólares, respectivamente.

\section{Gráfico 13 - Valor adicionado pelas empresas da amostra em 1997}

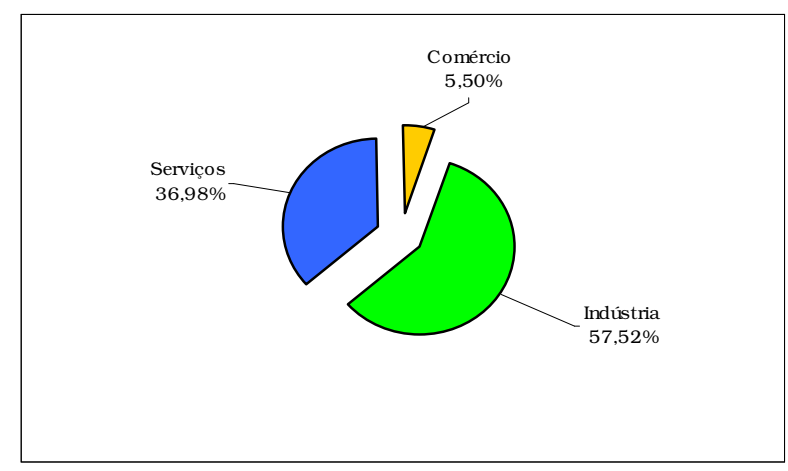

A distribuição do valor adicionado no ano de 1997 pelos ramos de atividade está explicitada nos Gráficos 14 a 16.

\section{Gráfico 14 - Distribuição do valor adicionado em 1997 - Comércio}

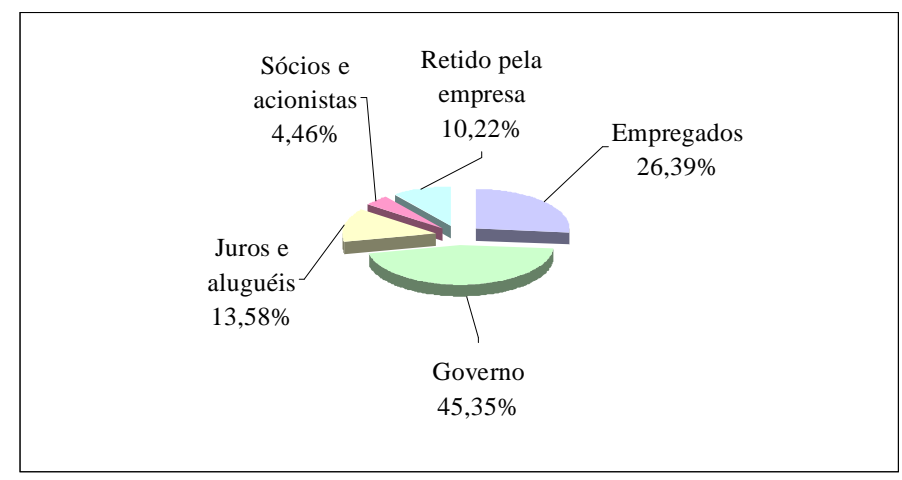

A absorção de recursos pelos agentes, no comércio, continua semelhante à de 1996. Governo em primeiro lugar com ligeiro declínio, empregados em segundo com 
pequeno acréscimo, e sócios e acionistas em último, também com pequeno acréscimo.

\section{Gráfico 15 - Distribuição do valor adicionado em 1997 - Indústria}

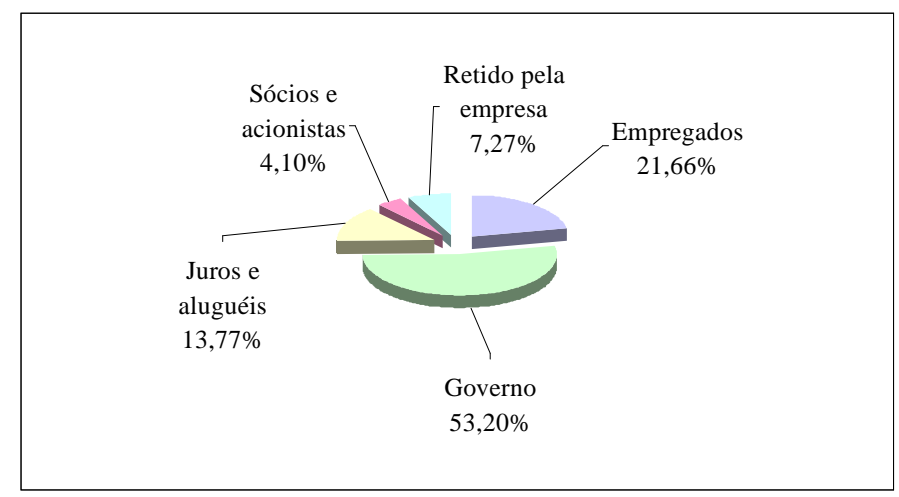

A mesma situação de 1996 é observada em 1997 na indústria. Contudo, houve leve decréscimo no percentual distribuído a empregados, e acréscimo naquele distribuído ao governo e aos sócios e acionistas, estes em último lugar.

\section{Gráfico 16 - Distribuição do valor adicionado em 1997 - Serviços}

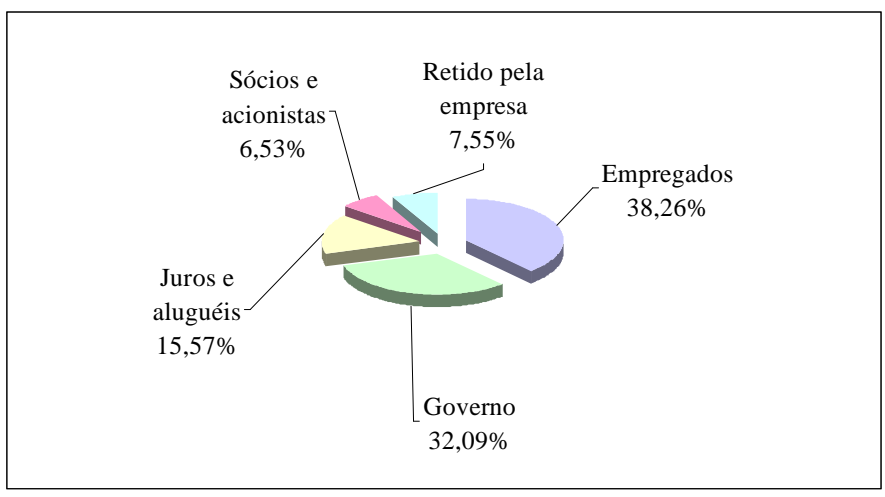

O ramo de serviços mantém, também a mesma situação de 1996, com os empregados ocupando o primeiro lugar na distribuição, seguidos pelo governo. Contudo, ambos tiveram queda. Observou-se mudança na última colocação, que agora é ocupada pelos sócios e acionistas. 
Das 10 maiores geradoras de valor adicionado em 1997, 4 são industriais com $38,31 \%$ do total e $66,58 \%$ do ramo, e as outras 6 prestadoras de serviço, com $21,87 \%$ do total e $59,54 \%$ do ramo. A situação quanto às empresas com valor adicionado negativo se repete.

O valor adicionado pelas empresas da amostra no ano de 1998 encontra-se no Gráfico 17.

\section{Gráfico 17 - Valor adicionado pelas empresas da amostra em 1998}

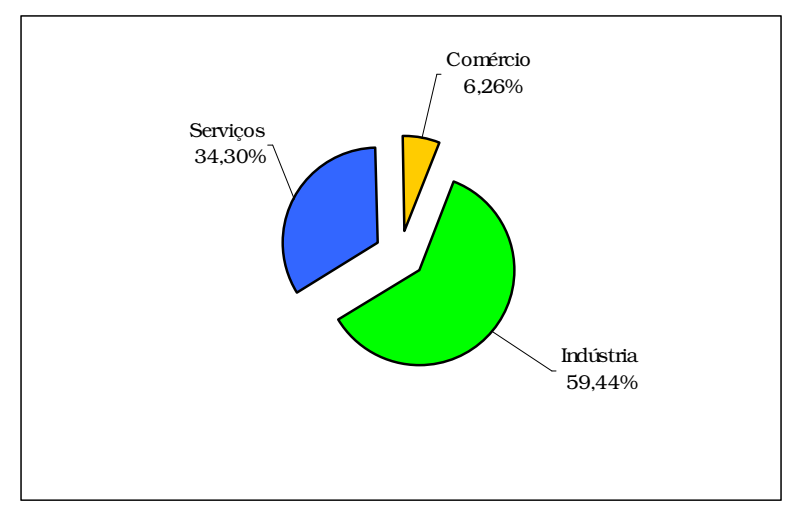

O cenário de 1998 é com o comércio gerando 6,26\% de toda a riqueza (2,91 bilhões), a indústria $59,44 \%$ ( 27,52 bilhões) e os serviços $34,3 \%$ (15,87 bilhões), distribuídos conforme Gráficos 18 a 20.

\section{Gráfico 18 - Distribuição do valor adicionado em 1998 - Comércio}

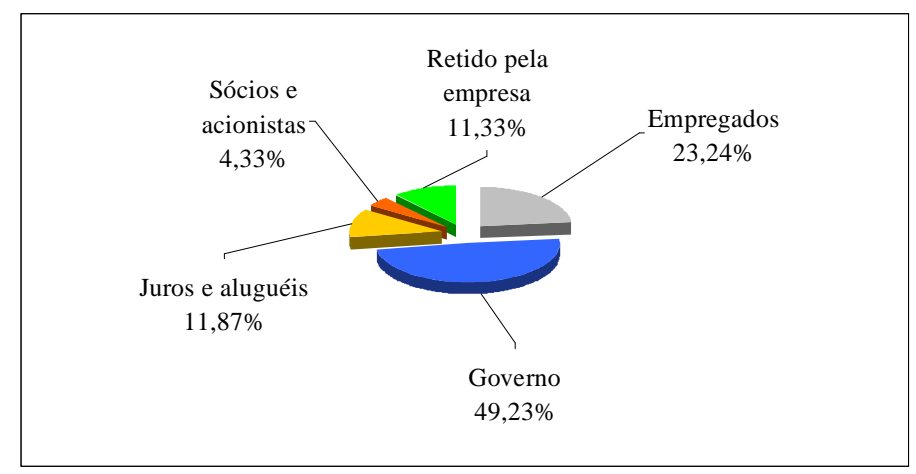


Também aqui, a situação continua a mesma de 1997, com o governo como o maior consumidor de valor adicionado, seguido pelos empregados, com sócios e acionistas em último lugar.

\section{Gráfico 19 - Distribuição do valor adicionado em 1998 - Indústria}

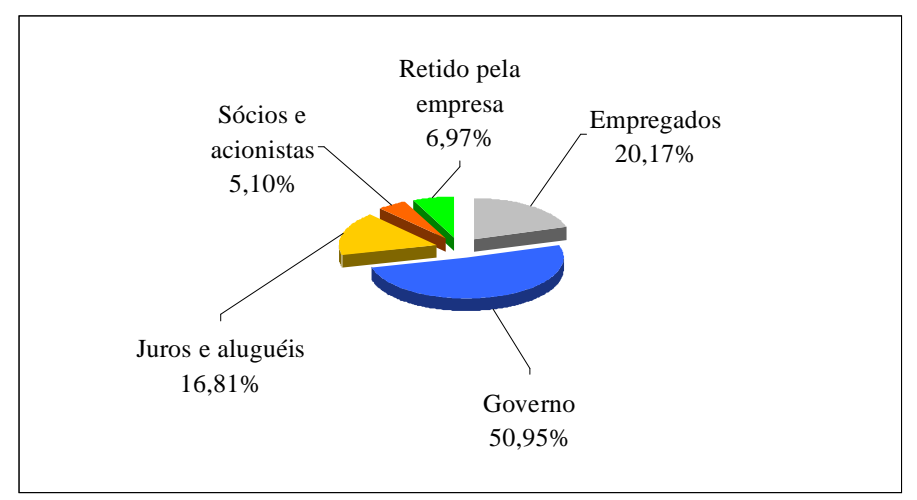

Governo, empregados e sócios e acionistas continuam ocupando primeiro, segundo e último lugares na distribuição de valor adicionado, a exemplo de 1996 e 1997.

\section{Gráfico 20 - Distribuição do valor adicionado em 1998 - Serviços}

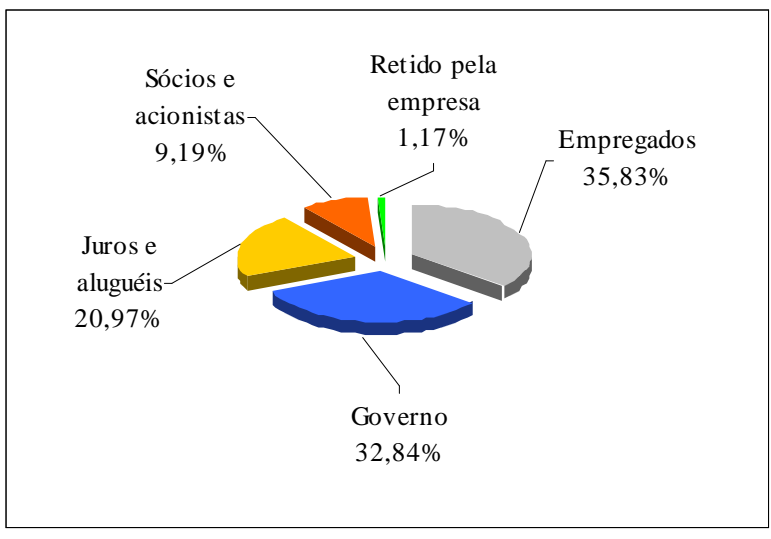

Em 1998, nota-se mudança nos serviços, com o percentual retido pelas empresas voltando a ocupar a última colocação, da mesma forma que em 1996. Novamente empregados em primeiro lugar e governo em segundo. 
Uma empresa comercial esteve presente entre as 10 maiores geradoras de riqueza em 1998 , com $2,45 \%$ do valor total e $38,83 \%$ do ramo; 4 foram industriais: $39,05 \%$ do valor adicionado total e $65,7 \%$ de ramo; e 5 prestadoras de serviço, com $18,1 \%$ do total e 52,8\% do ramo. Neste ano, apenas 1 empresa prestadora de serviços apresentou valor adicionado negativo.

A riqueza gerada pelas empresas da amostra de acordo com o ramo de atividade, em 1999, está representada no Gráfico 21.

\section{Gráfico 21 - Valor adicionado pelas empresas da amostra em 1999}

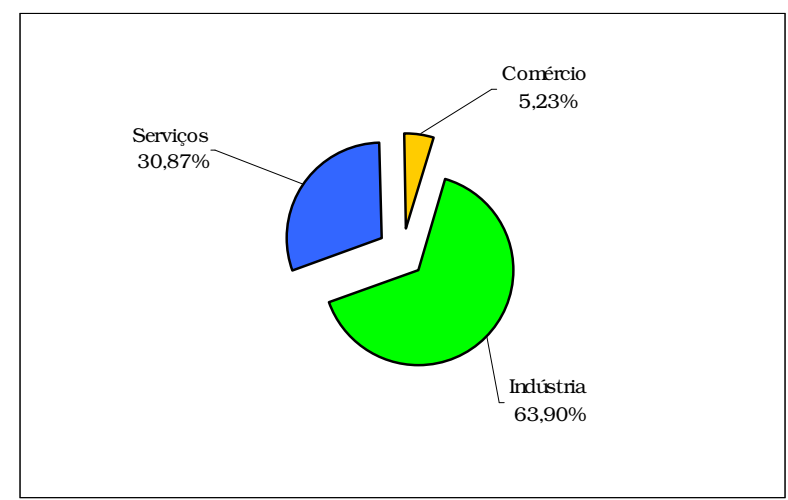

Para 1999, o comércio deteve 2,77 bilhões $(5,23 \%)$ da riqueza gerada distribuídos conforme Gráfico 22; a indústria: 33,83 bilhões (63,9\%), conforme Gráfico 23; e serviços: 16,34 bilhões (30,87\%), conforme Gráfico 24.

\section{Gráfico 22 - Distribuição do valor adicionado em 1999 - Comércio}

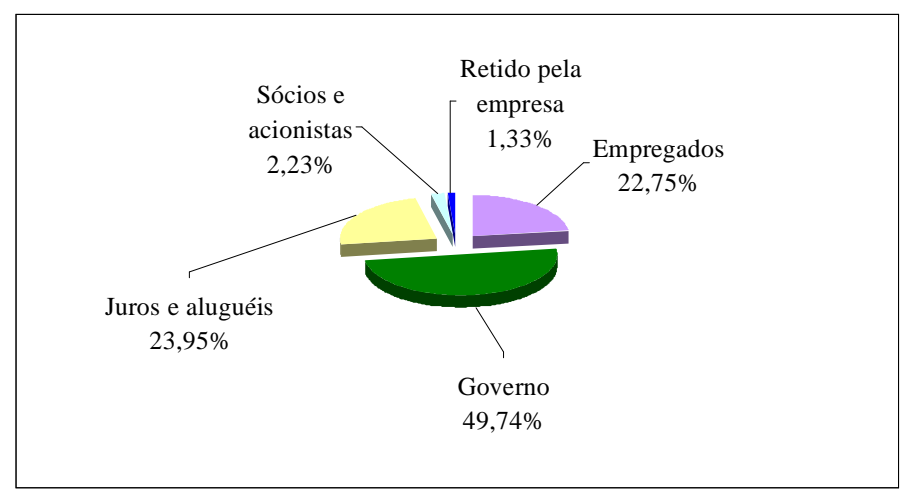


Em função da variação cambial ocorrida no $1^{\circ}$. Trimestre de 1999 , aqui se observa o governo como maior consumidor de valor adicionado, em segundo lugar juros e aluguéis, em terceiro empregados e em último o valor retido pelas empresas.

\section{Gráfico 23 - Distribuição do valor adicionado em 1999 - Indústria}

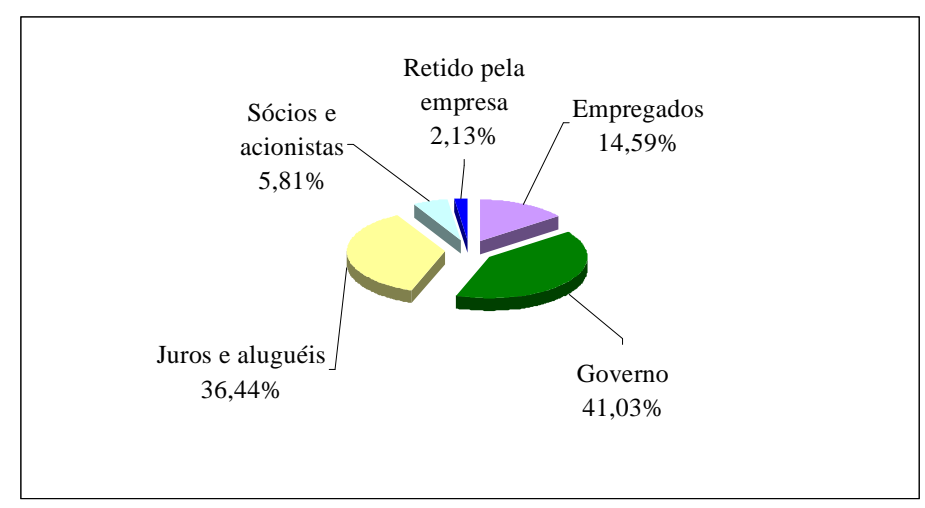

Também no ramo industrial juros e aluguéis passam a ocupar segunda colocação, governo primeira, empregados terceira e percentual retido pelas empresas a última.

\section{Gráfico 24 - Distribuição do valor adicionado em 1999 - Serviços}

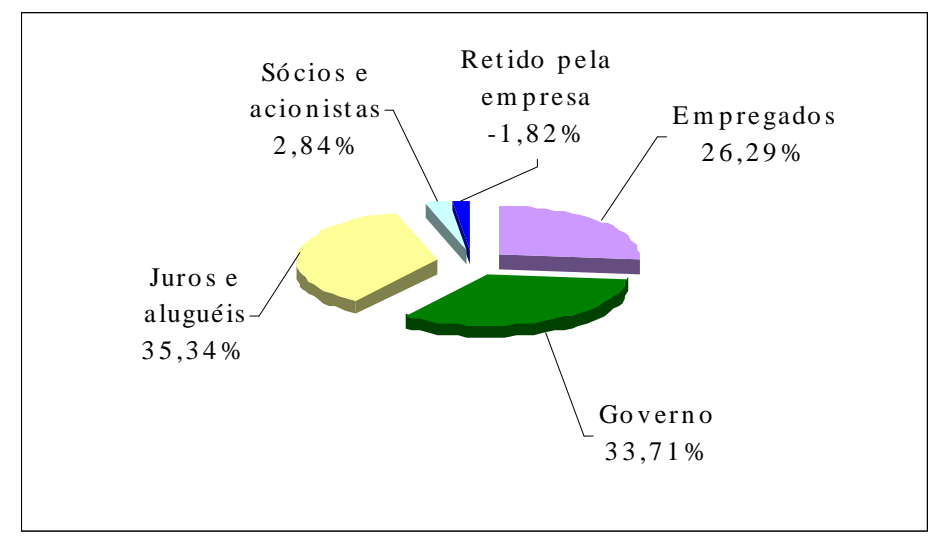

Situação bastante adversa no ramo de serviços, com juros e aluguéis recebendo a maior distribuição de valor adicionado, governo em segundo, e o percentual retido pelas empresas em último, inclusive com valor negativo, significando prejuízo. Os empregados ocuparam a terceira colocação na distribuição. 
Estão presentes 5 indústrias e 5 prestadoras de serviços entre as 10 maiores geradoras de riqueza em 1999, com $43 \%$ do total para as primeiras e $67,31 \%$ do ramo e $16,12 \%$ do total para as últimas e $52,2 \%$ do ramo de atividades. Neste período não houve empresas com valor adicionado negativo. O impacto da variação cambial afetou igualmente a distribuição de valor adicionado de todos os ramos de atividade.

O valor adicionado pelas empresas da amostra em 2000 está expresso no Gráfico 25 .

\section{Gráfico 25 - Valor adicionado pelas empresas da amostra em 2000}

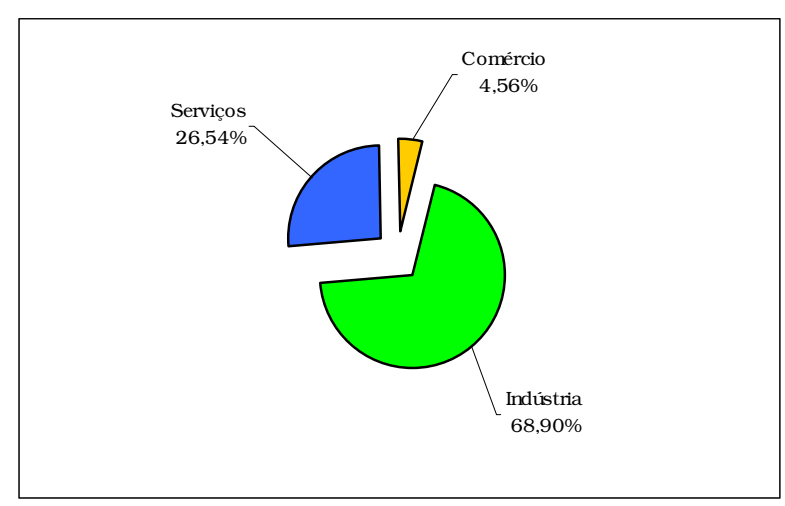

Finalmente, em 2000, o ramo comercial foi responsável por 2,48 bilhões $(4,56 \%)$ da geração da amostra, o industrial 37,51 bilhões $(68,9 \%)$ e o de serviços 14,45 bilhões $(26,54 \%)$. A distribuição ocorreu conforme Gráficos 26 a 28.

\section{Gráfico 26 - Distribuição do valor adicionado em 2000 - Comércio}

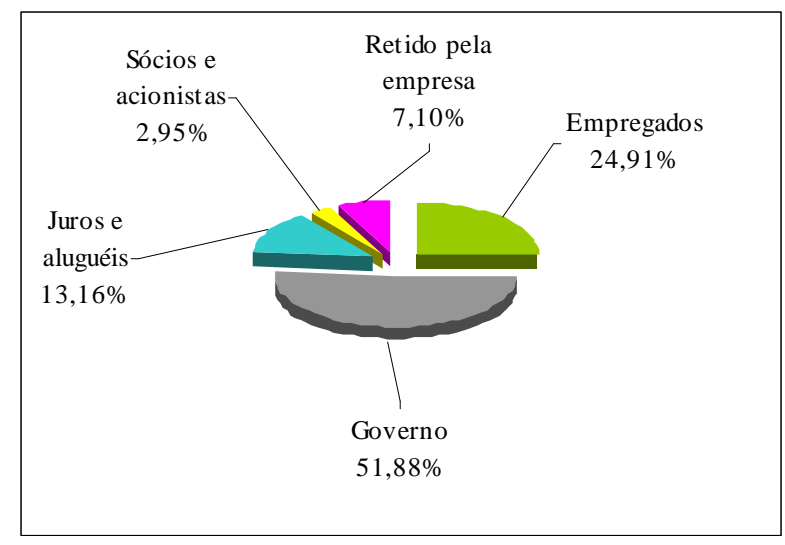

Observa-se a mesma distribuição de 1998, com governo em primeiro, empregados em segundo, e sócios e acionistas em último. 
Gráfico 27 - Distribuição do valor adicionado em 2000 - Indústria

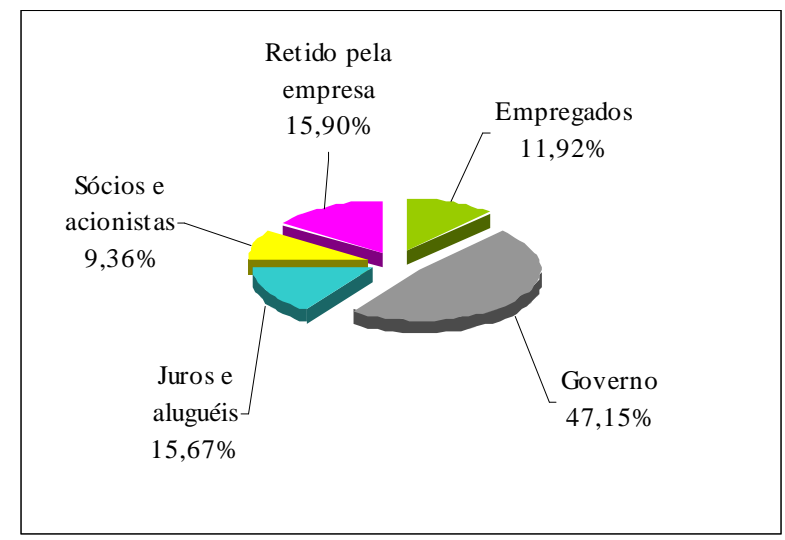

Alteração bastante significativa no ramo industrial. O governo não perde o primeiro lugar mas, o percentual retido pelas empresas passa a ocupar o segundo, com sócios e acionistas em último. Os empregados ocupam o penúltimo lugar.

\section{Gráfico 28 - Distribuição do valor adicionado em 2000 - Serviços}

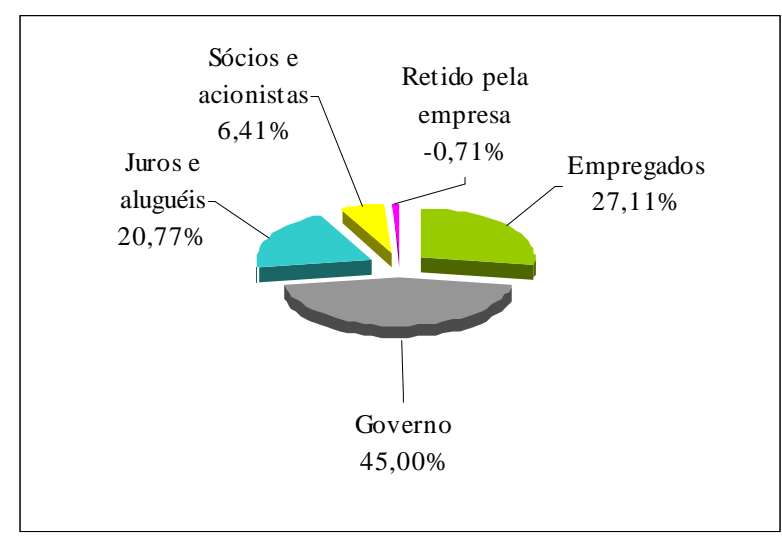

Pela primeira vez o governo é o maior beneficiário no ramo de serviços, com empregados em segundo, e o percentual retido em último, novamente negativo.

A média de pessoas que cada ramo empregou ao longo do período está na Tabela 8 .

Tabela 8 - Número médio de empregados e percentual de 1997 a 2000

\begin{tabular}{c|r|c|r|r|r|c}
\hline Ano/Ramo & Comércio & \% & \multicolumn{1}{c|}{ Indústria } & \% & \multicolumn{1}{c|}{ Serviços } & \% \\
\hline 1997 & 48.898 & 7,90 & 298.383 & 48,23 & 271.343 & 43,87 \\
\hline 1998 & 50.773 & 8,66 & 283.583 & 48,37 & 251.859 & 42,97 \\
\hline 1999 & 52.829 & 9,24 & 277.223 & 48,49 & 241.647 & 42,27 \\
\hline 2000 & 56.741 & 9,91 & 278.271 & 48,58 & 237.759 & 41,51 \\
\hline
\end{tabular}


O acompanhamento da média de empregados nos diversos ramos de atividade pode ser feito no Gráfico 29.

\section{Gráfico 29 - Média de empregados por ramos de atividade - 1997 a 2000}

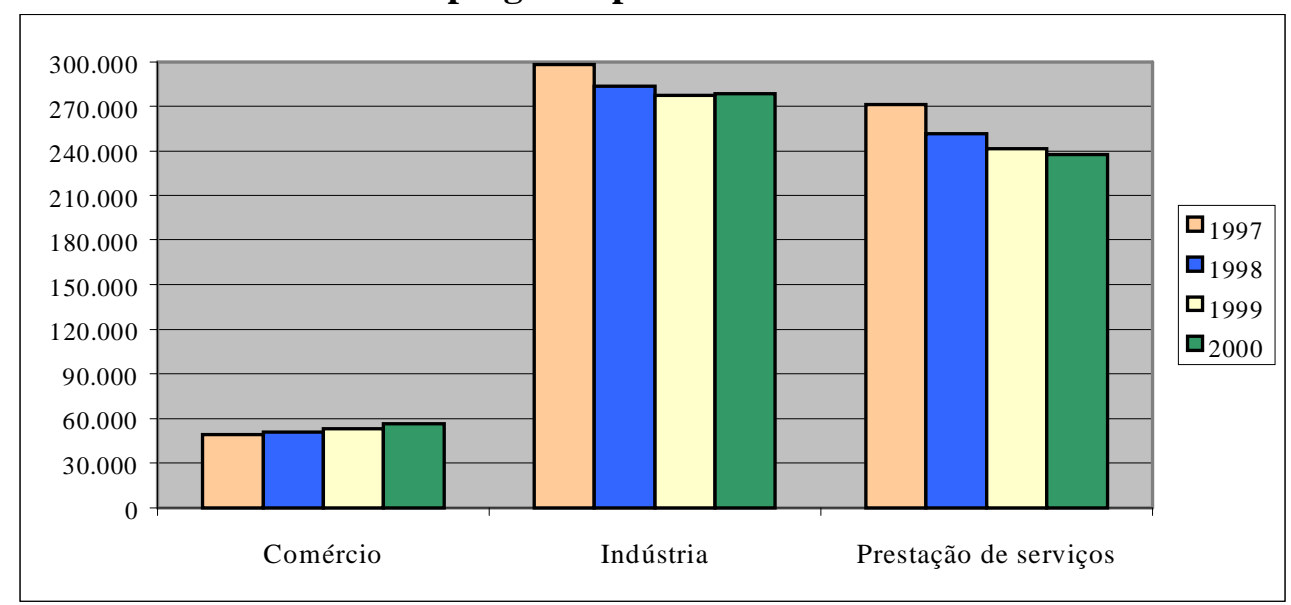

Observa-se que o ramo que mais empregou foi o industrial, e que as maiores variações ocorreram nos serviços.

Quanto ao valor adicionado por empregado de 1997 a 2000 está no Gráfico 30.

\section{Gráfico 30 - Valor adicionado por empregado de 1997 a 2000 - Por ramos}

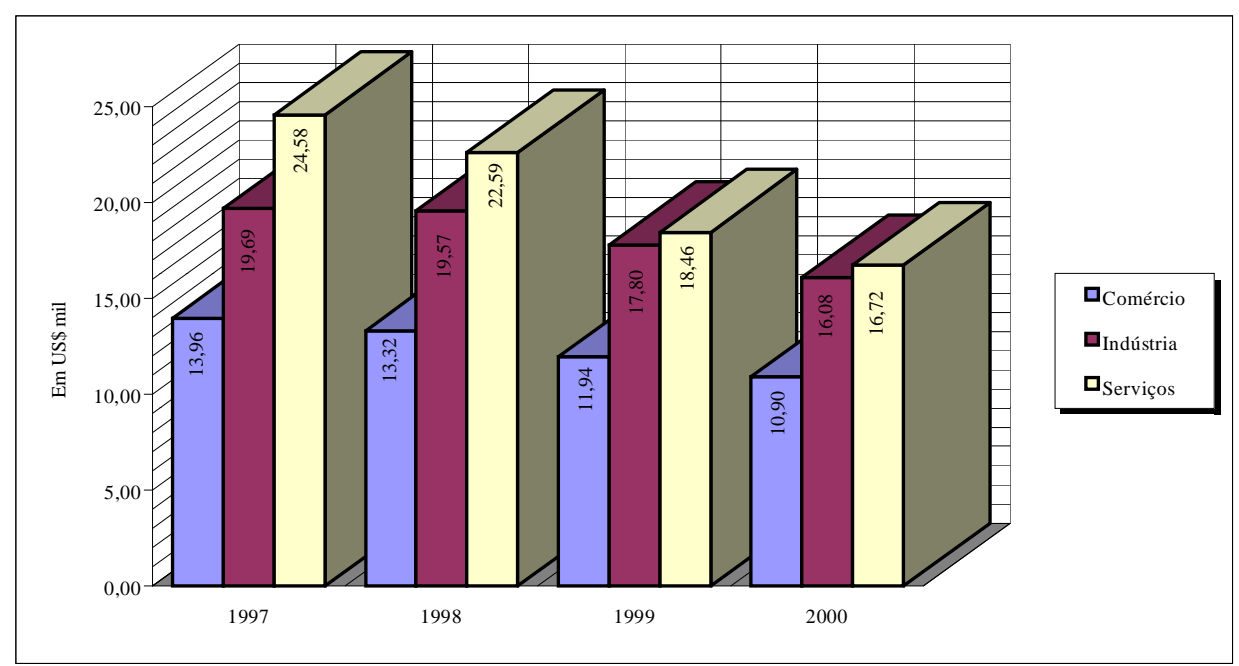

O ramo que detém o maior valor adicionado distribuído por empregado ao longo do período é o de serviços, com a indústria ocupando a segunda colocação, e o comércio em último. Mas, observa-se que em todos os ramos esse valor está em declínio. 
E ainda, em 1997, a empresa responsável pela distribuição do maior valor adicionado por empregado da amostra foi uma prestadora de serviços, com 101,95 mil dólares, e a de menor, uma indústria, com 3,34 mil; em 1998, duas indústrias ocuparam as posições, com 381,13 mil e 4,09 mil; em 1999 novamente uma indústria ocupou o primeiro lugar, com 281,91 mil, e um comércio o último, com 2,13 mil; e em 2000, observou-se a mesma situação de 1999, com uma indústria em primeiro lugar com 300,57 mil, e um comércio em último com 2,4 mil dólares.

Um resumo com as principais informações por ramos de atividade se encontra na Tabela 9. Pela observação desta tabela pode-se constatar que a riqueza criada pelo comércio durante o período analisado foi decrescente, de 1996 para 2000, 11,73\% a menos, aumentando apenas em 1998, baseado em 1997, em 12,55\%, e decrescendo novamente a partir daí. A mesma situação foi observada no ramo de serviços, com uma variação negativa de 1996 para 2000, de 5,56\%, havendo, entretanto, duas oscilações positivas ao longo do período: 13,88\% de 1996 para 1997 e 2,98\% de 1998 para 1999. O ramo industrial foi o único a ter um comportamento distinto, apresentando crescimento da riqueza ao longo de todo o período (46,44\%, de 1996 para 2000).

A participação percentual do valor adicionado na receita acompanhou o mesmo comportamento da riqueza, exceto no ramo industrial, onde a riqueza cresceu ano a ano, e na participação percentual do valor adicionado na receita, onde observou-se ligeiro decréscimo em 2000, comparado a 1999 - 4,49\%.

Dos diversos ramos, o de serviços apresentou a melhor distribuição percentual para os empregados, apesar de declinante ao longo do período, de 41,3\% em 1996 para $27,5 \%$ em 2000 (queda de 33,41\%). Na indústria caiu de 23,95\% (1996) para 11,93\% (2000), queda de 50,19\%.

O comércio apresentou ligeiro aumento na distribuição percentual para os empregados, de 22,72\% em 1996 para 24,92\% em 2000, acréscimo de 9,68\%; mas como a riqueza gerada caiu nesse ramo ao longo do período, esse aumento percentual 
Tabela 9 - Informações gerais - por ramos de atividade

\begin{tabular}{|c|c|c|c|c|c|}
\hline \multirow{2}{*}{ Inform ação } & \multicolumn{5}{|c|}{ Comércio } \\
\hline & 1996 & 1997 & 1998 & 1999 & 2000 \\
\hline VA gerado (em US\$ mil) & 2.811 .295 & 2.586 .956 & 2.911 .545 & 2.771 .656 & 2.481 .629 \\
\hline Participação \% do VA no PIB & 0,49 & 0,43 & 0,47 & 5,11 & 0,45 \\
\hline Participação \% do VA na receita & 19,25 & 16,79 & 19,13 & 16,35 & 14,10 \\
\hline \multicolumn{6}{|l|}{ Distribuição do VA } \\
\hline Pessoal e encargos (em US\$ mil) & 638.656 & 682.452 & 676.492 & 630.509 & 618.421 \\
\hline$\%$ no VA total & 22,72 & 26,38 & 23,23 & 22,75 & 24,92 \\
\hline Impostos, taxas e contribuições (em US\$ mil) & 1.630 .838 & 1.173 .221 & 1.433 .444 & 1.378 .560 & 1.287 .408 \\
\hline \% no VA total & 58,01 & 45,35 & 49,23 & 49,74 & 51,88 \\
\hline Juros e aluguéis (em US\$ mil) & 252.299 & 351.381 & 345.579 & 663.946 & 326.468 \\
\hline \% no VA total & 8,97 & 13,58 & 11,87 & 23,95 & 13,16 \\
\hline JCP e dividendos (em US\$ mil) & 92.648 & 115.414 & 126.036 & 61.677 & 73.197 \\
\hline \% no VA total & 3,30 & 4,46 & 4,33 & 2,23 & 2,95 \\
\hline Lucros/prejuízos retidos (em US\$ mil) & 196.854 & 264.488 & 329.994 & 36.964 & 176.135 \\
\hline \% no VA total & 7,00 & 10,22 & 11,33 & 1,33 & 7,10 \\
\hline Número médio de empregados & & 48.898 & 50.773 & 52.829 & 56.741 \\
\hline \multirow[t]{3}{*}{ VA por empregado (em US\$ mil) } & & 13,96 & 13,32 & 11,94 & 10,90 \\
\hline & \multicolumn{5}{|c|}{ Indústria } \\
\hline & 1996 & 1997 & 1998 & 1999 & 2000 \\
\hline VA gerado (em US\$ mil) & 25.614 .316 & 27.112 .982 & 27.517 .153 & 33.831 .468 & 37.509 .756 \\
\hline Participação \% do VA no PIB & 4,44 & 4,53 & 4,46 & 6,24 & 6,75 \\
\hline Participação \% do VA na receita & 49,81 & 52,94 & 55,85 & 60,19 & 57,49 \\
\hline \multicolumn{6}{|l|}{ Distribuição do VA } \\
\hline Pessoal e encargos (em US\$ mil) & 6.133 .780 & 5.875 .099 & 5.550 .675 & 4.935 .923 & 4.474 .112 \\
\hline \% no VA total & 23,95 & 21,67 & 20,17 & 14,59 & 11,93 \\
\hline Impostos, taxas e contribuições (em US\$ mil) & 13.592 .152 & 14.423 .479 & 14.019 .698 & 13.882 .205 & 17.686 .965 \\
\hline \% no VA total & 53,06 & 53,20 & 50,95 & 41,03 & 47,15 \\
\hline Juros e aluguéis (em US\$ mil) & 3.282 .842 & 3.732 .300 & 4.624 .618 & 12.326 .593 & 5.876 .940 \\
\hline \% no VA total & 12,82 & 13,77 & 16,81 & 36,44 & 15,67 \\
\hline JCP e dividendos (em US\$ mil) & 1.015 .816 & 1.110 .315 & 1.403 .507 & 1.965 .889 & 3.509 .212 \\
\hline$\%$ no VA total & 3,97 & 4,10 & 5,10 & 5,81 & 9,36 \\
\hline Lucros/prejuízos retidos (em US\$ mil) & 1.589 .726 & 1.971 .789 & 1.918 .655 & 720.858 & 5.962 .527 \\
\hline$\%$ no VA total & 6,21 & 7,27 & 6,97 & 2,13 & 15,90 \\
\hline Número médio de empregados & & 298.383 & 283.583 & 277.223 & 278.271 \\
\hline \multirow[t]{3}{*}{ VA por empregado (em US\$ mil) } & & 19,69 & 19,57 & 17,80 & 16,08 \\
\hline & \multicolumn{5}{|c|}{ Serviços } \\
\hline & 1996 & 1997 & 1998 & 1999 & 2000 \\
\hline VA gerado (em US\$ mil) & 15.302 .745 & 17.426 .367 & 15.871 .531 & 16.344 .949 & 14.452 .592 \\
\hline Participação \% do VA no PIB & 2,65 & 2,91 & 2,57 & 3,02 & 2,60 \\
\hline Participação \% do VA na receita & 54,97 & 58,92 & 53,59 & 54,98 & 47,70 \\
\hline \multicolumn{6}{|l|}{ Distribuição do VA } \\
\hline Pessoal e encargos (em US\$ mil) & 6.319 .639 & 6.668 .887 & 5.688 .314 & 4.459 .842 & 3.975 .152 \\
\hline \% no VA total & 41,30 & 38,27 & 35,84 & 27,29 & 27,50 \\
\hline Impostos, taxas e contribuições (em US\$ mil) & 5.308 .864 & 5.591 .495 & 5.211 .630 & 5.716 .847 & 6.596 .236 \\
\hline$\%$ no VA total & 34,69 & 32,09 & 32,84 & 34,98 & 45,64 \\
\hline Juros e aluguéis (em US\$ mil) & 2.804 .191 & 2.713 .974 & 3.327 .670 & 5.995 .876 & 3.045 .738 \\
\hline$\%$ no VA total & 18,32 & 15,57 & 20,97 & 36,68 & 21,07 \\
\hline JCP e dividendos (em US\$ mil) & 548.891 & 1.137 .104 & 1.458 .388 & 481.770 & 939.230 \\
\hline$\%$ no VA total & 3,59 & 6,53 & 9,19 & 2,95 & 6,50 \\
\hline Lucros/prejuízos retidos (em US\$ mil) & 321.160 & 1.314 .907 & 185.529 & $(309.386)$ & $(103.764)$ \\
\hline$\%$ no VA total & 2,10 & 7,55 & 1,17 & $(1,89)$ & $(0,72)$ \\
\hline Número médio de empregados & & 271.343 & 251.859 & 241.647 & 237.759 \\
\hline VA por empregado (em US\$ mil) & & 24,58 & 22,59 & 18,46 & 16,72 \\
\hline
\end{tabular}


na distribuição a empregados não se traduziu em aumento no valor distribuído em dólares.

Quanto ao número médio de empregados, apenas o comércio apresentou aumento nos postos de trabalho, de 7.843 vagas (16,04\%); a indústria perdeu $20.112(6,74 \%)$ vagas e as prestadoras de serviços $33.584(12,38 \%)$, todas relativas ao período de 2000 comparado ao de 1997.

Ao se analisar o valor distribuído a cada empregado, constatou-se: no comércio, queda de 21,92\% de 1997 para 2000, conseqüência do decréscimo na distribuição em dólares para os empregados e do aumento no número de pessoas empregadas - mais empregados com menor remuneração.

$\mathrm{Na}$ indústria, queda de $18,33 \%$ no valor adicionado por empregado - apesar da diminuição das vagas oferecidas, houve decréscimo substancial $(27,06 \%$ de 1996 para 2000), também no valor em dólares distribuído aos empregados - representando menos empregos e menor remuneração.

No ramo de serviços, constatou-se a maior queda no valor distribuído a cada empregado, 31,98\% de 1997 a 2000 - número de vagas decrescente e distribuição em dólares também (37,1\% de 1996 para 2000) - também aqui, menos empregos e menor remuneração.

No tocante à participação do governo na distribuição do valor adicionado, o único ramo que apresentou acréscimo no percentual de participação e no valor em dólares foi o de serviços, de 34,69\% em 1996 (5,31 bilhões), para 45,64\% em 2000 (6,59 bilhões) - demonstrando aumento na carga tributária; o comércio apresentou queda tanto na participação percentual, de 58,01\% para 51,88\%, quanto no montante em dólares, de 1,63 bilhões para 1,29 bilhões - como a riqueza gerada também diminuiu, não há evidência de aumento na carga tributária; e a indústria, que apresentou queda na participação percentual, de 53,06\% para $47,15 \%$, e acréscimo no valor em dólares 
de 13,59 bilhões para 17,69 bilhões, fruto do aumento na geração de riquezas, demonstrando diminuição na carga tributária.

Observa-se, também, que o ramo de serviços foi o que menos distribuiu riqueza para o governo, constatando-se, assim, uma menor carga tributária.

Quanto aos valores distribuídos para juros e aluguéis e aos sócios e acionistas e àqueles retidos pelas empresas, a constatação foi a mesma quando da análise da amostra em conjunto.

\subsection{Análise por Setores}

Para proceder a uma análise setorial, dividiu-se a amostra de 198 empresas nos 25 setores utilizados para a elaboração de Melhores e Maiores e descritos anteriormente. A composição dos setores ficou distribuída conforme Gráfico 31.

\section{Gráfico 31 - Número de empresas por setor}

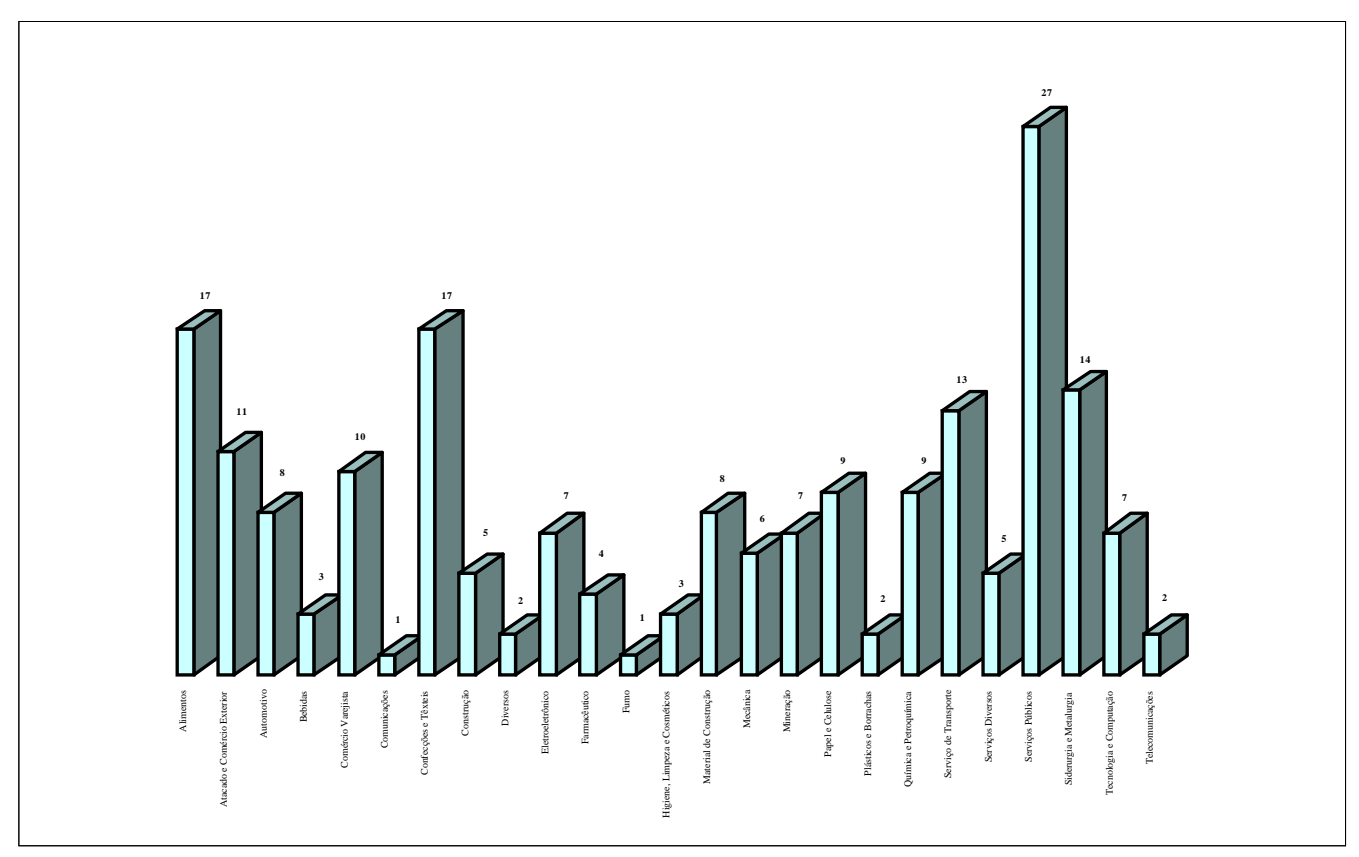


Os setores mais populosos, portanto mais representativos, são: serviços públicos, confecções e têxteis, e alimentos. Os setores de fumo e comunicações foram representados por uma empresa cada um.

No ano de 1996, apenas os setores de alimentos, atacado e comércio exterior, confecções e têxteis, fumo, mineração, papel e celulose, química e petroquímica, serviços públicos, siderurgia e metalurgia, e telecomunicações, geraram riqueza acima de 1 bilhão de dólares. Os maiores criadores de valor adicionado se encontram selecionados no Gráfico 32.

\section{Gráfico 32 - Maiores geradores de valor adicionado em 1996}

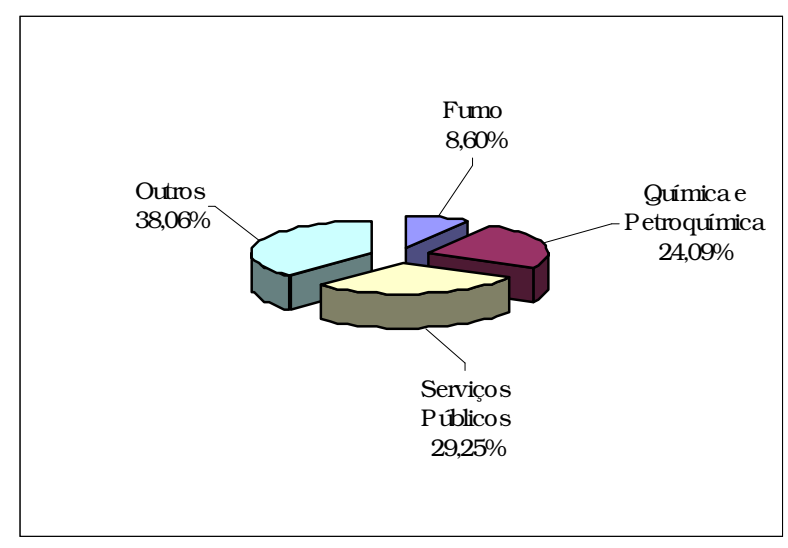

Como observado, o destaque ficou nos setores de serviços públicos, química e petroquímica, e fumo, este apesar de ser representado por uma única empresa.

Os 3 setores que mais distribuíram valor adicionado para pessoal e encargos, em termos percentuais, ao longo de 1996, e que pertencem ao ramo de serviços, e os 3 que menos distribuíram, encontram-se no Gráfico 33. 


\section{Gráfico 33 - Maiores e menores distribuidores a empregados em 1996}

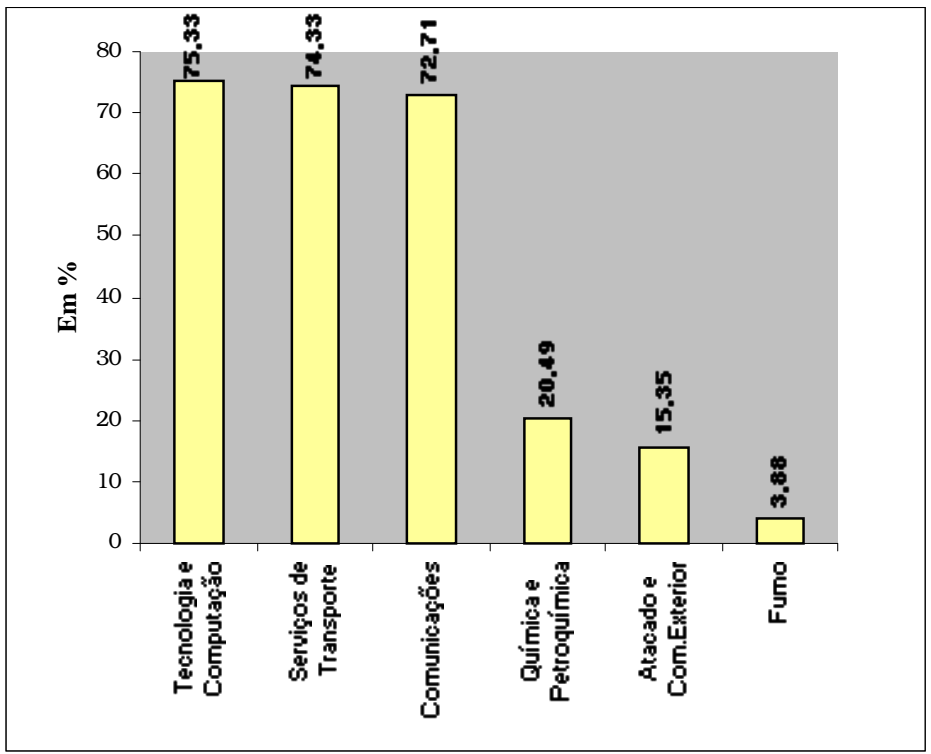

Destaque para tecnologia e computação como maior distribuidor aos empregados, e fumo como o menor.

Para os anos de 1997, 1998, 1999 e 2000, os setores geradores de valor adicionado superior a 1 bilhão de dólares foram os mesmos de 1996, exceto pelos setores de papel e celulose e confecções e têxteis, que nos anos de 1997 e 1998 perderam esta condição e, em 2000, o setor de confecções e têxteis perdeu-a novamente. A posição dos três maiores geradores de valor adicionado se alternou, de 1997 a 1999, entre os mesmos ocupantes do posto no ano de 1996.

Esta constatação, e ainda, os setores com maiores e menores percentuais de distribuição para os empregados, é possível por meio dos Gráficos 34 a 41. 
Gráfico 34 - Maiores geradores de valor adicionado em 1997

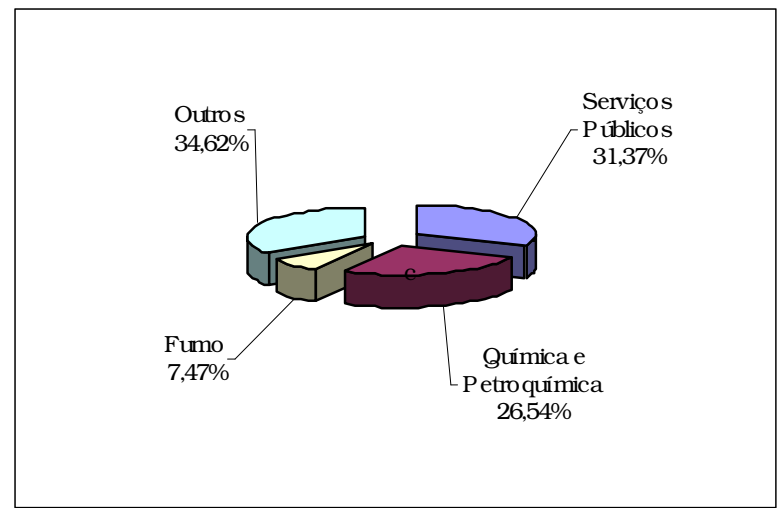

Destaque para serviços públicos, acompanhado de química e petroquímica e de fumo.

Gráfico 35 - Maiores e menores distribuidores a empregados em 1997

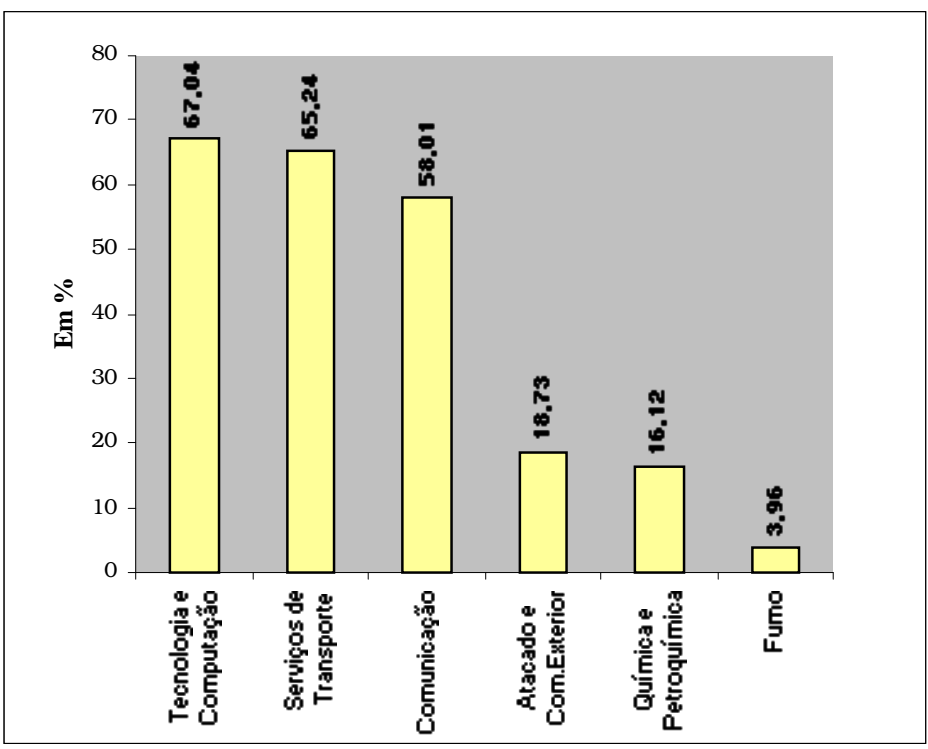

Destaque para tecnologia e computação, serviços de transporte, e comunicação, como maiores distribuidores. O setor de fumo é o que menos distribuiu a empregados. 
Gráfico 36 - Maiores geradores de valor adicionado em 1998

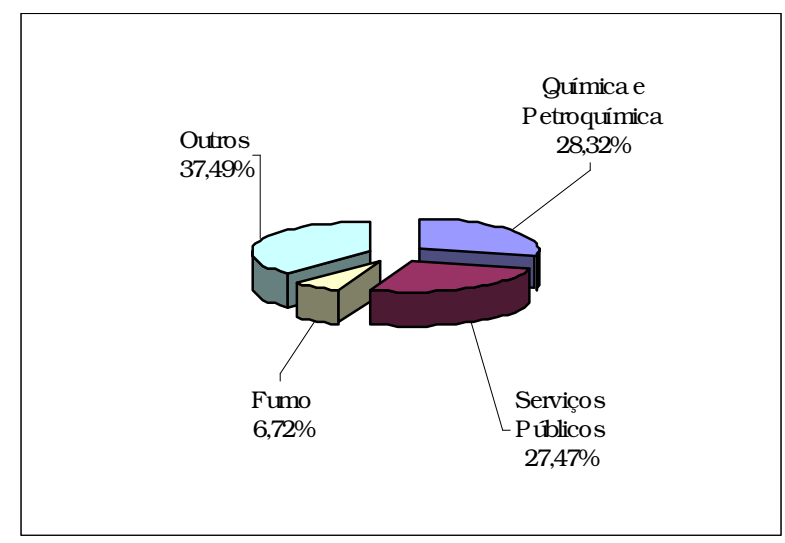

Inversão de posições de destaque: em primeiro química e petroquímica, depois serviços públicos. Fumo continua em terceiro lugar.

Gráfico 37 - Maiores e menores distribuidores a empregados em 1998

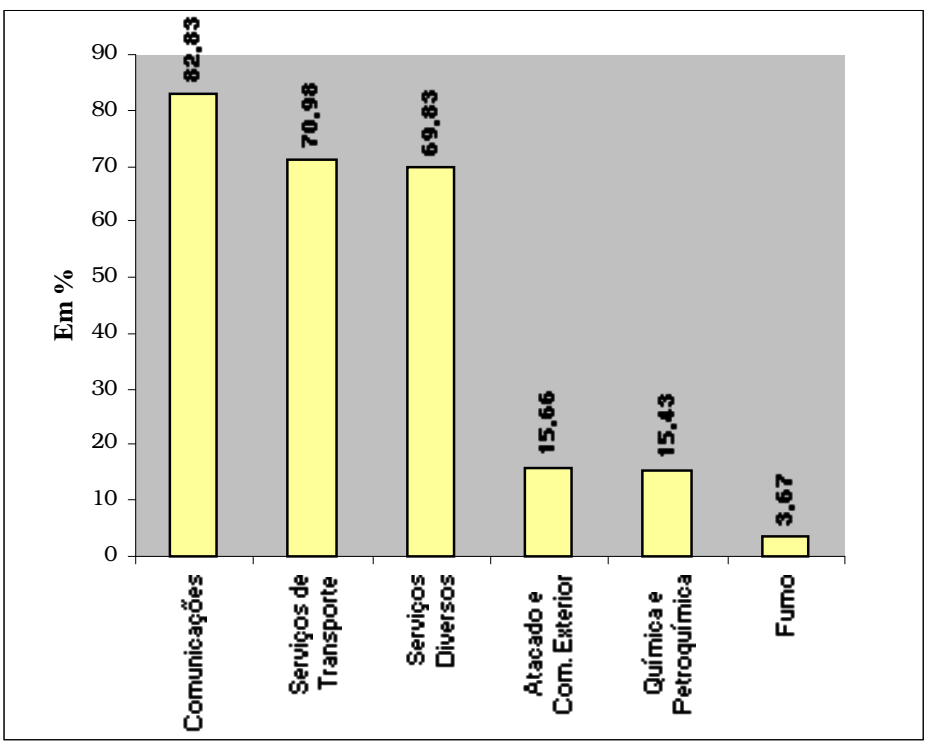

Aqui os maiores distribuidores são: comunicações, serviços de transporte, e serviços diversos. Fumo ainda é o menor distribuidor. Ressalte-se a saída do setor de tecnologia e informação e o surgimento do setor de serviços diversos. 
Gráfico 38 - Maiores geradores de valor adicionado em 1999

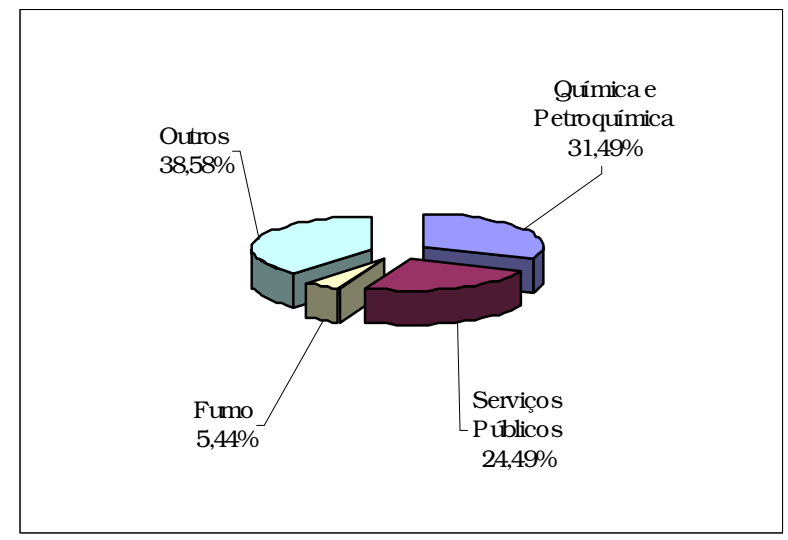

Continua o mesmo posicionamento de 1998.

Gráfico 39 - Maiores e menores distribuidores a empregados em 1999

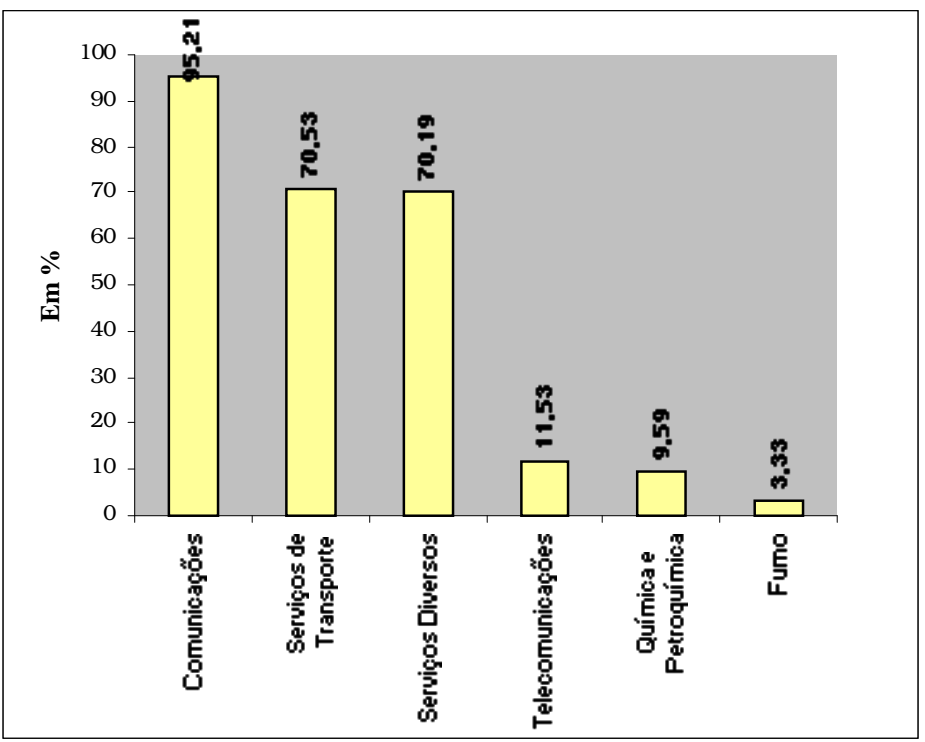

Os maiores distribuidores são os mesmos do ano anterior. O setor de fumo ainda é o último colocado. 


\section{Gráfico 40 - Maiores geradores de valor adicionado em 2000}

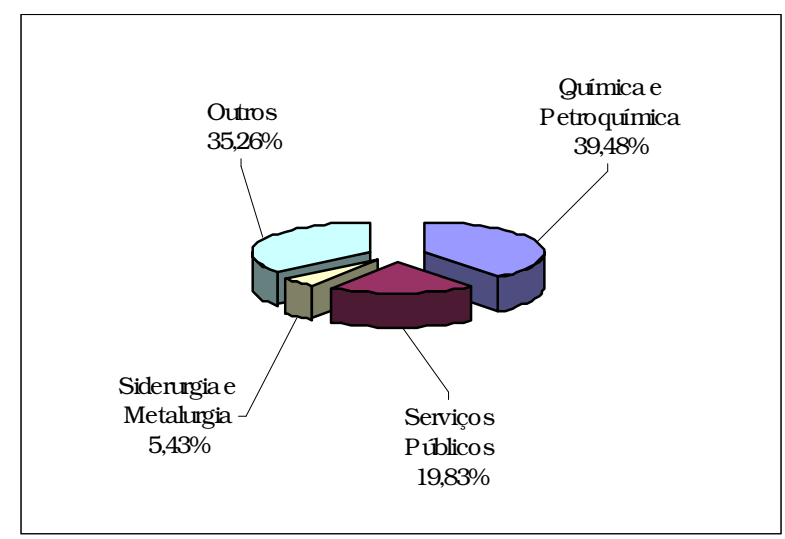

Alteração total em relação aos anos anteriores: química e petroquímica passa a ter uma parcela mais expressiva, praticamente o dobro de serviços públicos, e siderurgia e metalurgia substitui fumo, que nos períodos anteriores ocupou o terceiro lugar.

Gráfico 41 - Maiores e menores distribuidores a empregados em 2000

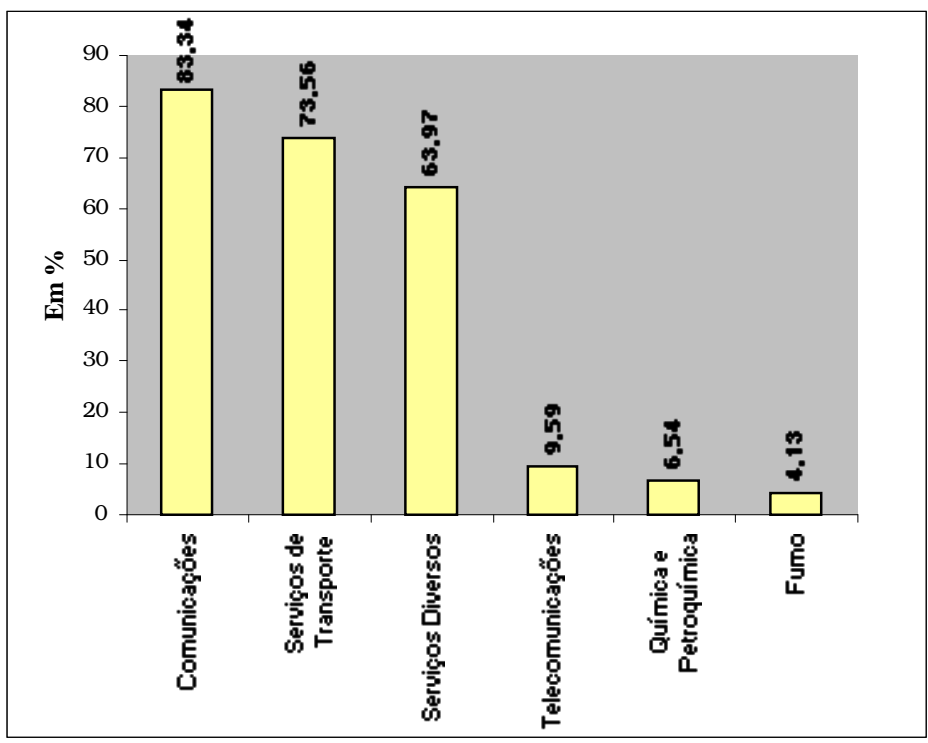

Em 2000 observa-se a mesma posição de 1998 e 1999. O setor de fumo apresentou ligeiro acréscimo, mais ainda é o que menos distribui. 
Os setores que geraram menor valor adicionado de 1996 a 2000 foram, plásticos e borrachas e comunicações conforme destacado na Tabela 10.

Tabela 10 - Menores geradores de valor adicionado de 1996 a 2000

\begin{tabular}{|c|c|c|}
\hline Ano/Setores & $\begin{array}{c}\text { Plásticos e borrachas } \\
\text { Em US\$ mil } \\
\end{array}$ & $\begin{array}{c}\text { Comunicações } \\
\text { Em US\$ mil }\end{array}$ \\
\hline 1996 & 27,61 & 24,78 \\
\hline 1997 & 30,23 & 28,74 \\
\hline 1998 & 32,66 & 27,04 \\
\hline 1999 & 26,67 & 23,34 \\
\hline 2000 & 31,93 & 22,83 \\
\hline
\end{tabular}

Com relação à distribuição ao governo, a situação praticamente se inverte, como pode ser observado nos Gráficos 42 a 46, representativos dos anos de 1996 a 2000. Os setores que mais contribuíram com o governo são os que menos distribuíram recursos para pessoal e encargos.

\section{Gráfico 42 - Maiores e menores distribuidores ao governo em 1996}

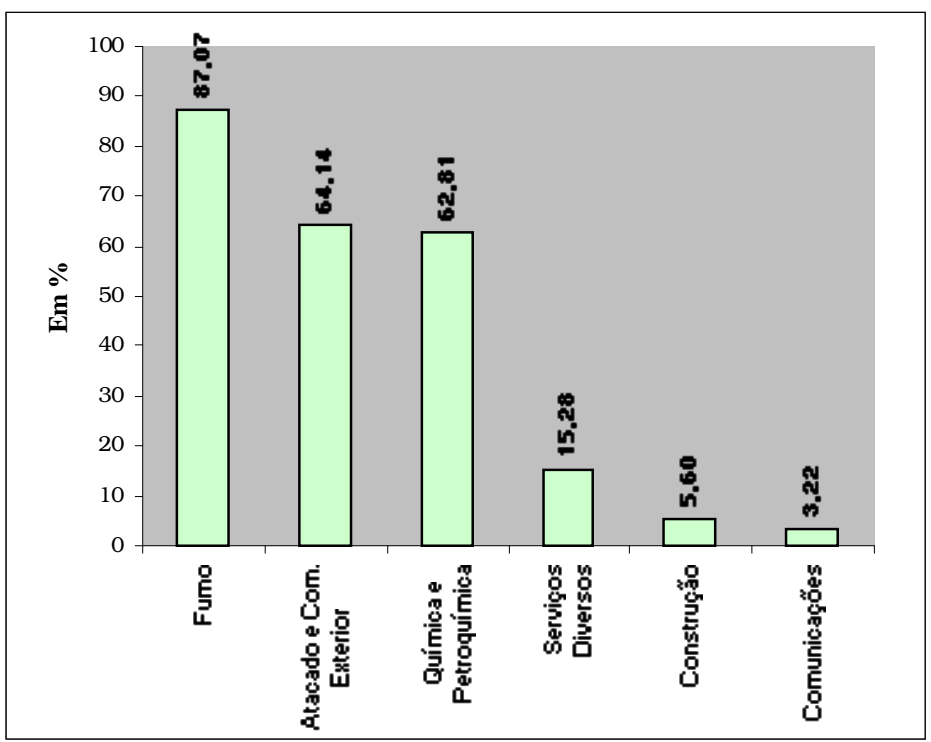

Destaque para fumo como o maior distribuidor ao governo, e comunicações como o menor. 
Gráfico 43 - Maiores e menores distribuidores ao governo em 1997

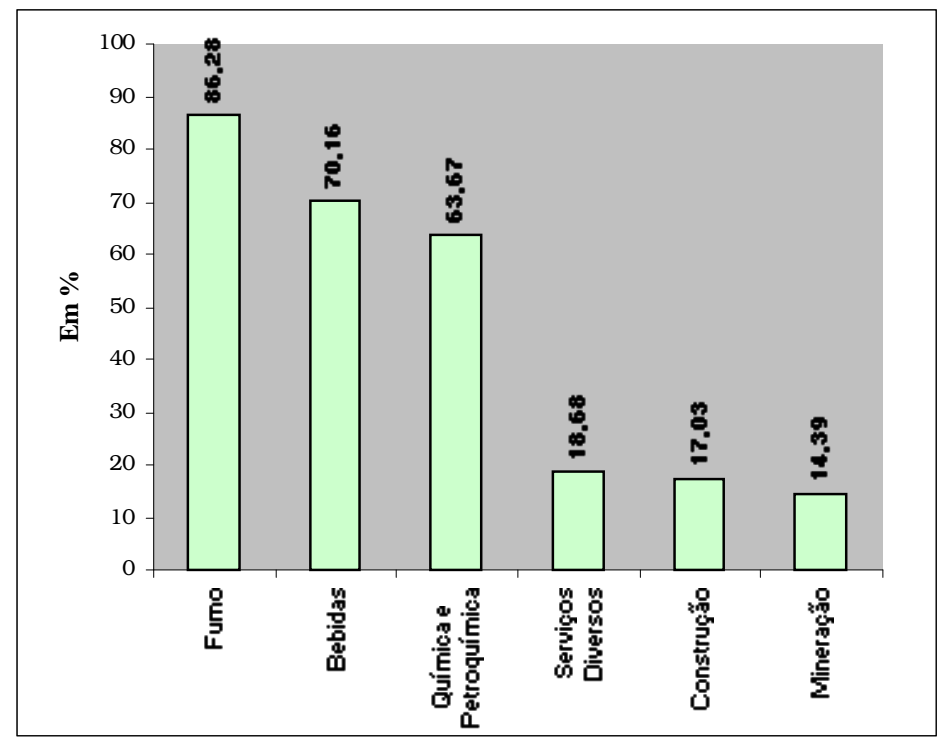

Novamente fumo ocupa a primeira posição mas, a última passa a ser ocupada pela mineração.

Gráfico 44 - Maiores e menores distribuidores ao governo em 1998

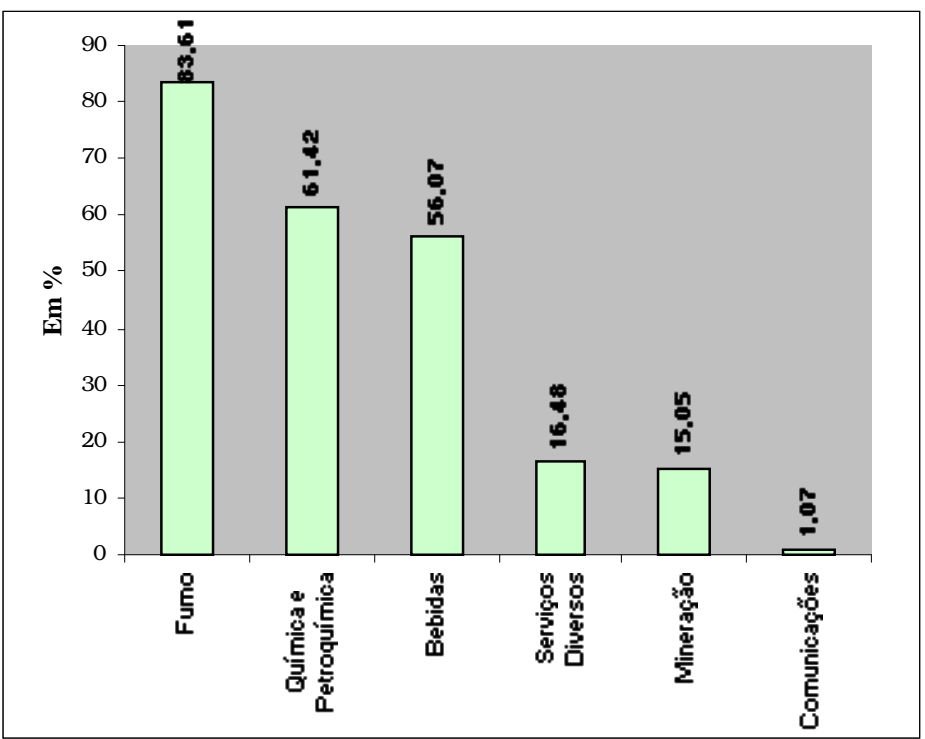

Fumo em primeiro lugar e o último volta a ser ocupado pela comunicação. 
Gráfico 45 - Maiores e menores distribuidores ao governo em 1999

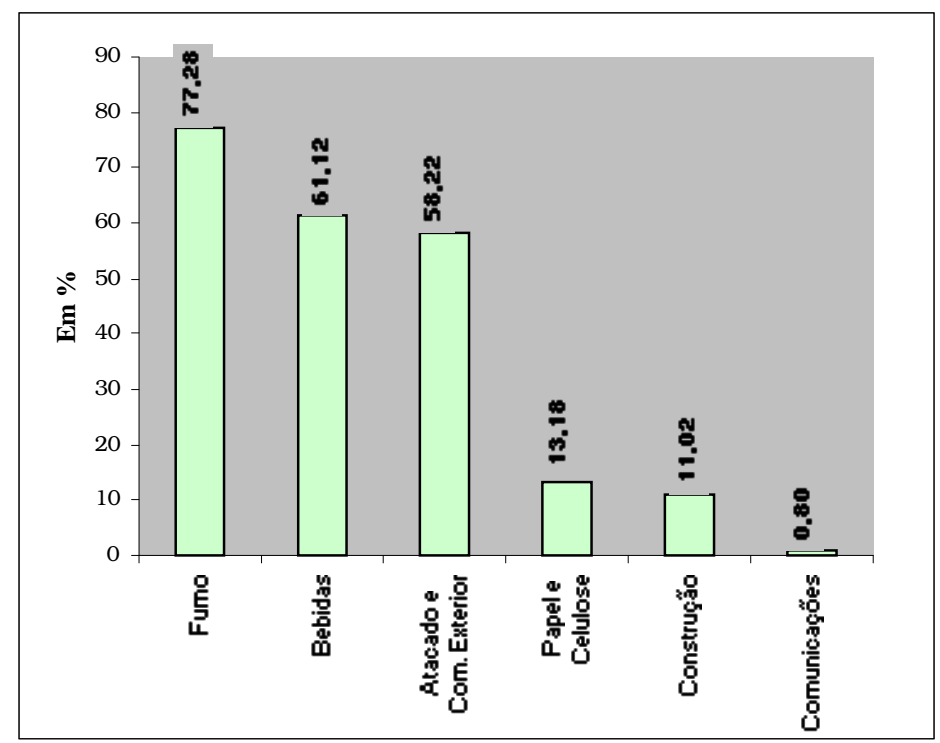

Observa-se a mesma posição de 1998, mas com percentuais em decréscimo.

Gráfico 46 - Maiores e menores distribuidores ao governo em 2000

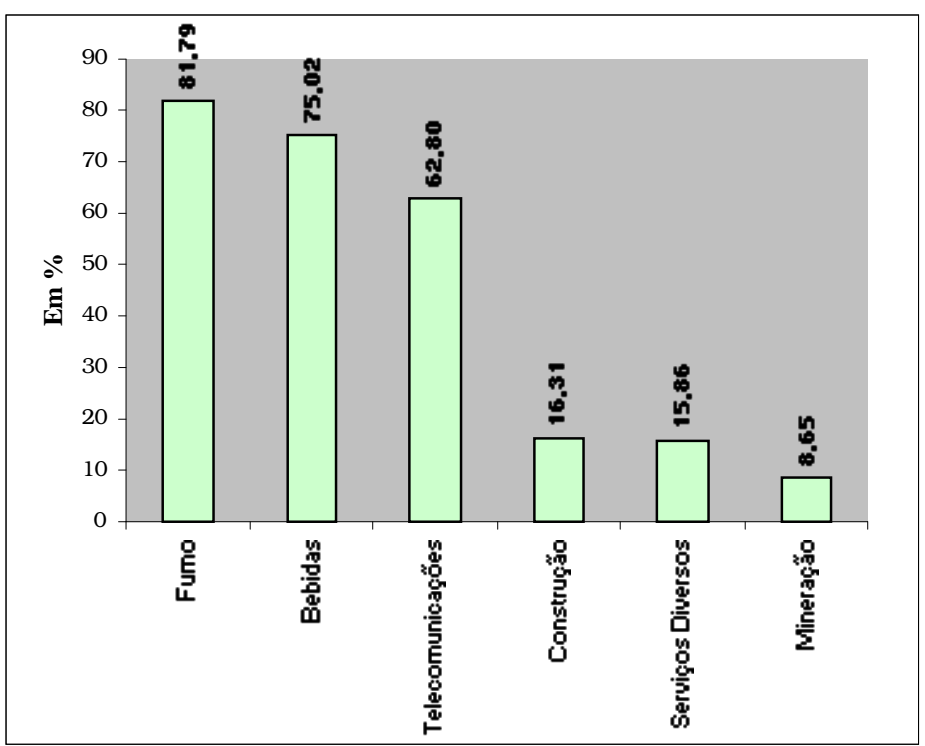

Volta o posicionamento de 1997, contudo, o percentual do menor distribuidor ao governo, mineração, caiu quase a metade. 
$\mathrm{Na}$ sequência apresentam-se as informações segmentadas por setor, com a distribuição da riqueza aos outros agentes que contribuíram para sua criação, assim como o resumo dos dados, nas Tabelas 11 a 35.

\section{Tabela 11- Informações gerais por setores: Alimentos}

\begin{tabular}{l|r|r|r|r|r}
\hline \multicolumn{1}{c|}{ Ano/Informação } & \multicolumn{1}{c|}{$\mathbf{1 9 9 6}$} & \multicolumn{1}{c|}{$\mathbf{1 9 9 7}$} & \multicolumn{1}{c|}{$\mathbf{1 9 9 8}$} & \multicolumn{1}{c}{$\mathbf{1 9 9 9}$} & \multicolumn{1}{c}{$\mathbf{2 0 0 0}$} \\
\hline VA gerado (em US\$ mil) & 1.869 .924 & 1.777 .270 & 1.869 .196 & 1.997 .313 & 1.578 .765 \\
\hline Participação \% do VA no PIB & 0,32 & 0,30 & 0,30 & 0,37 & 0,28 \\
\hline Participação \% do VA na receita & 36,01 & 33,83 & 35,71 & 38,33 & 30,34 \\
\hline Distribuição do VA & & & & & \\
\hline Pessoal e encargos (em US\$ mil) & 502.283 & 509.233 & 495.083 & 474.057 & 409.131 \\
\hline \% no VA total & 26,86 & 28,65 & 26,49 & 23,73 & 25,91 \\
\hline Impostos, taxas e contribuições (em US\$ mil) & 723.112 & 655.652 & 654.395 & 614.811 & 656.357 \\
\hline \% no VA total & 38,67 & 36,89 & 35,01 & 30,78 & 41,57 \\
\hline Juros e aluguéis (em US\$ mil) & 340.713 & 287.231 & 356.160 & 686.896 & 257.941 \\
\hline \% no VA total & 18,22 & 16,16 & 19,05 & 34,39 & 16,34 \\
\hline JCP e dividendos (em US\$ mil) & 9.991 & 4.614 & 52.108 & 91.252 & 83.668 \\
\hline \% do VA total & 0,53 & 0,26 & 2,79 & 4,57 & 5,30 \\
\hline Lucros/prejuízos retidos (em US\$ mil) & 293.825 & 320.540 & 311.450 & 130.297 & 171.668 \\
\hline \% do VA total & 15,71 & 18,04 & 16,66 & 6,52 & 10,87 \\
\hline Média de empregados & & 36.245 & 35.711 & 35.876 & 35.987 \\
\hline VA por empregado (em US\$ mil) & & 14,05 & 13,86 & 13,21 & 11,37 \\
\hline
\end{tabular}

Tabela 12 - Informações gerais por setores: Atacado e comércio exterior

\begin{tabular}{l|r|r|r|r|r}
\multicolumn{1}{c|}{ Ano/Informação } & \multicolumn{1}{c|}{$\mathbf{1 9 9 6}$} & \multicolumn{1}{c|}{$\mathbf{1 9 9 7}$} & \multicolumn{1}{c}{$\mathbf{1 9 9 8}$} & \multicolumn{1}{c}{$\mathbf{1 9 9 9}$} & \multicolumn{1}{c}{$\mathbf{2 0 0 0}$} \\
\hline VA ge rado (em US\$ mil) & 1.970 .080 & 1.661 .623 & 1.965 .222 & 1.838 .070 & 1.645 .933 \\
\hline Participação \% do VA no PIB & 0,34 & 0,28 & 0,32 & 0,34 & 0,30 \\
\hline Participação \% do VA na receita & 16,54 & 13,34 & 16,18 & 13,44 & 11,69 \\
\hline Distribuição do VA & & & & & \\
\hline Pessoal e encargos (em US\$ mil) & 302.332 & 311.223 & 307.718 & 277.844 & 276.894 \\
\hline \% no VA total & 15,35 & 18,73 & 15,66 & 15,12 & 16,82 \\
\hline Impostos, taxas e contribuições (em US\$ mil) & 1.263 .554 & 829.386 & 1.061 .098 & 1.070 .080 & 967.048 \\
\hline \% no VA total & 64,14 & 49,91 & 53,99 & 58,22 & 58,75 \\
\hline Juros e aluguéis (em US\$ mil) & 184.945 & 239.745 & 219.205 & 398.623 & 184.096 \\
\hline \% no VA total & 9,39 & 14,43 & 11,15 & 21,69 & 11,18 \\
\hline JCP e dividendos (em US\$ mil) & 80.612 & 88.294 & 113.766 & 47.651 & 61.232 \\
\hline \% do VA total & 4,09 & 5,31 & 5,79 & 2,59 & 3,72 \\
\hline Lucros/prejuízos retidos (em US\$ mil) & 138.637 & 192.975 & 263.435 & 43.872 & 156.663 \\
\hline \% do VA total & 7,04 & 11,61 & 13,40 & 2,39 & 9,52 \\
\hline Média de empregados & & 18.776 & 20.022 & 20.934 & 21.738 \\
\hline VA por empregado (em US\$ mil) & & 16,58 & 15,37 & 13,27 & 12,74 \\
\hline
\end{tabular}


Tabela 13- Informações gerais por setores: Automotivo

\begin{tabular}{l|r|r|r|r|r}
\hline \multicolumn{1}{c|}{ Ano/Informação } & $\mathbf{1 9 9 6}$ & \multicolumn{1}{c|}{$\mathbf{1 9 9 7}$} & \multicolumn{1}{c|}{$\mathbf{1 9 9 8}$} & \multicolumn{1}{c|}{$\mathbf{1 9 9 9}$} & \multicolumn{1}{c}{$\mathbf{2 0 0 0}$} \\
\hline VA ge rado (em US\$ mil) & 435.070 & 499.564 & 524.245 & 485.241 & 509.080 \\
\hline Participação \% do VA no PIB & 0,08 & 0,08 & 0,08 & 0,09 & 0,09 \\
\hline Participação \% do VA na receita & 36,05 & 33,98 & 34,09 & 34,21 & 30,19 \\
\hline Distribuição do VA & & & & & \\
\hline Pessoal e encargos (em US\$ mil) & 218.852 & 218.503 & 221.187 & 193.735 & 194.763 \\
\hline \% no VA total & 50,30 & 43,74 & 42,19 & 39,93 & 38,26 \\
\hline Impostos, taxas e contribuições (em US\$ mil) & 129.795 & 141.078 & 139.691 & 114.285 & 125.242 \\
\hline \% no VA total & 29,83 & 28,24 & 26,65 & 23,55 & 24,60 \\
\hline Juros e aluguéis (em US\$ mil) & 53.955 & 67.310 & 82.546 & 186.803 & 99.090 \\
\hline \% no VA total & 12,40 & 13,47 & 15,75 & 38,50 & 19,46 \\
\hline JCP e di videndos (em US\$ mil) & 23.920 & 55.391 & 28.756 & 5.974 & 68.670 \\
\hline \% do VA total & 5,50 & 11,09 & 5,49 & 1,23 & 13,49 \\
\hline Lucros/prejuízos retidos (em US\$ mil) & 8.548 & 17.282 & 52.065 & $(15.556)$ & 21.315 \\
\hline \% do VA total & 1,96 & 3,46 & 9,93 & $(3,21)$ & 4,19 \\
\hline Média de empregados & & 15.549 & 15.590 & 14.734 & 15.540 \\
\hline VA por empregado (em US\$ mil) & & 14,05 & 14,19 & 13,15 & 12,53 \\
\hline
\end{tabular}

Tabela 14- Informações gerais por setores: Bebidas

\begin{tabular}{l|r|r|r|r|r}
\hline \multicolumn{1}{c|}{ Ano/Informação } & \multicolumn{1}{c|}{$\mathbf{1 9 9 6}$} & \multicolumn{1}{c|}{$\mathbf{1 9 9 7}$} & \multicolumn{1}{c|}{$\mathbf{1 9 9 8}$} & \multicolumn{1}{c|}{$\mathbf{1 9 9 9}$} & \multicolumn{1}{c}{$\mathbf{2 0 0 0}$} \\
\hline VA gerado (em US\$ mil) & 672.972 & 405.244 & 473.719 & 632.128 & 685.383 \\
\hline Participação \% do VA no PIB & 0,12 & 0,07 & 0,08 & 0,12 & 0,12 \\
\hline Participação \% do VA na receita & 44,89 & 36,79 & 51,76 & 50,54 & 48,92 \\
\hline Distribuição do VA & & & & & \\
\hline Pessoal e encargos (em US\$ mil) & 155.577 & 125.441 & 85.114 & 161.165 & 92.899 \\
\hline \% no VA total & 23,12 & 30,95 & 17,97 & 25,50 & 13,55 \\
\hline Impostos, taxas e contribuiçôs (em US\$ mil) & 379.070 & 284.339 & 265.616 & 386.348 & 514.152 \\
\hline \% no VA total & 56,33 & 70,16 & 56,07 & 61,12 & 75,02 \\
\hline Juros e aluguéis (em US\$ mil) & 77.727 & 59.498 & 80.317 & 110.512 & 69.978 \\
\hline \% no VA total & 11,55 & 14,68 & 16,95 & 17,48 & 10,21 \\
\hline JCP e di videndos (em US\$ mil) & 35.987 & 27.955 & 11.140 & 6.326 & 3.426 \\
\hline \% do VA total & 5,35 & 6,90 & 2,35 & 1,00 & 0,50 \\
\hline Lucros/prejuízos retidos (em US\$ mil) & 24.611 & $(91.989)$ & 31.532 & $(32.223)$ & 4.928 \\
\hline \% do VA total & 3,66 & $(22,70)$ & 6,66 & $(5,10)$ & 0,72 \\
\hline Mé dia de empregados & & 8.715 & 8.114 & 8.598 & 7.522 \\
\hline VA por empregado (em US\$ mil) & & 14,39 & 10,49 & 18,75 & 12,35 \\
\hline
\end{tabular}


Tabela 15- Informações gerais por setores: Comércio varejista

\begin{tabular}{l|r|r|r|r|r}
\hline \multicolumn{1}{c|}{ Ano/Informação } & $\mathbf{1 9 9 6}$ & \multicolumn{1}{c|}{$\mathbf{1 9 9 7}$} & \multicolumn{1}{c|}{$\mathbf{1 9 9 8}$} & \multicolumn{1}{c}{$\mathbf{1 9 9 9}$} & \multicolumn{1}{c}{$\mathbf{2 0 0 0}$} \\
\hline VA ge rado (em US\$ mil) & 841.215 & 925.333 & 946.323 & 933.586 & 835.696 \\
\hline Participação \% do VA no PIB & 0,15 & 0,15 & 0,15 & 0,17 & 0,15 \\
\hline Participação \% do VA na receita & 31,24 & 31,36 & 30,76 & 28,47 & 23,73 \\
\hline Distribuição do VA & & & & & \\
\hline Pessoal e encargos (em US\$ mil) & 336.324 & 371.229 & 368.774 & 352.665 & 341.527 \\
\hline \% no VA total & 39,98 & 40,12 & 38,97 & 37,78 & 40,87 \\
\hline Impostos, taxas e contribuições (em US\$ mil) & 367.284 & 343.835 & 372.346 & 308.480 & 320.360 \\
\hline \% no VA total & 43,66 & 37,16 & 39,35 & 33,04 & 38,33 \\
\hline Juros e aluguéis (em US\$ mil) & 67.354 & 112 & 126.374 & 265.323 & 142.372 \\
\hline \% no VA total & 8,01 & 12,06 & 13,35 & 28,42 & 17,04 \\
\hline JCP e di videndos (em US\$ mil) & 12.036 & 27.120 & 12.270 & 14.026 & 11.965 \\
\hline \% do VA total & 1,43 & 2,93 & 1,30 & 1,50 & 1,43 \\
\hline Lucros/prejuízos retidos (em US\$ mil) & 58.217 & 71.513 & 66.559 & $(6.908)$ & 19.472 \\
\hline \% do VA total & 6,92 & 7,73 & 7,03 & $(0,74)$ & 2,33 \\
\hline Média de empregados & & 30.123 & 30.752 & 31.895 & 35.003 \\
\hline VA por empregado (em US\$ mil) & & 12,32 & 11,99 & 11,06 & 9,76 \\
\hline
\end{tabular}

Tabela 16- Informações gerais por setores: Comunicações

\begin{tabular}{l|r|r|r|r|r}
\multicolumn{1}{c|}{ Ano/Informação } & \multicolumn{1}{c|}{$\mathbf{1 9 9 6}$} & \multicolumn{1}{c|}{$\mathbf{1 9 9 7}$} & \multicolumn{1}{c|}{$\mathbf{1 9 9 8}$} & \multicolumn{1}{c|}{$\mathbf{1 9 9 9}$} & \multicolumn{1}{c}{$\mathbf{2 0 0 0}$} \\
\hline VA gerado (em US\$ mil) & 24.781 & 28.735 & 27.040 & 23.335 & 22.826 \\
\hline Participação \% do VA no PIB & 0,004 & 0,005 & 0,004 & 0,004 & 0,004 \\
\hline Participação \% do VA na receita & 45,59 & 48,88 & 48,22 & 45,38 & 46,56 \\
\hline Distribuição do VA & & & & & \\
\hline Pessoal e encargos (em US\$ mil) & 18.018 & 16.668 & 22.262 & 22.217 & 19.024 \\
\hline \% no VA total & 72,71 & 58,01 & 82,33 & 95,21 & 83,34 \\
\hline Impostos, taxas e contribuições (em US\$ mil) & 797 & 6.526 & 289 & 186 & 4.666 \\
\hline \% no VA total & 3,22 & 22,71 & 1,07 & 0,80 & 20,44 \\
\hline Juros e aluguéis (em US\$ mil) & 4.940 & 5.386 & 5.355 & 4.514 & 6.922 \\
\hline \% no VA total & 19,93 & 18,74 & 19,80 & 19,34 & 30,33 \\
\hline JCP e dividendos (em US\$ mil) & - & - & - & - & - \\
\hline \% do VA total & - & - & - & - & - \\
\hline Lucros/prejuízos retidos (em US\$ mil) & 1.026 & 155 & $(866)$ & $(3.582)$ & $(7.786)$ \\
\hline \% do VA total & 4,14 & 0,54 & $(3,20)$ & $(15,35)$ & $(34,11)$ \\
\hline Média de empregados & & 975 & 992 & 1.033 & 1.090 \\
\hline VA por empregado (em US\$ mil) & & 17,10 & 22,45 & 21,51 & 17,45 \\
\hline
\end{tabular}


Tabela 17 - Informações gerais por setores: Confecções e têxteis

\begin{tabular}{l|r|r|r|r|r}
\hline \multicolumn{1}{c|}{ Ano/Informação } & \multicolumn{1}{c|}{$\mathbf{1 9 9 6}$} & \multicolumn{1}{c|}{$\mathbf{1 9 9 7}$} & \multicolumn{1}{c|}{$\mathbf{1 9 9 8}$} & \multicolumn{1}{c|}{$\mathbf{1 9 9 9}$} & \multicolumn{1}{c}{$\mathbf{2 0 0 0}$} \\
\hline VA ge rado (em US\$ mil) & 1.011 .957 & 850.230 & 870.453 & 1.078 .935 & 903.696 \\
\hline Participação \% do VA no PIB & 0,18 & 0,14 & 0,14 & 0,20 & 0,16 \\
\hline Participação \% do VA na receita & 45,32 & 40,10 & 40,96 & 48,04 & 41,45 \\
\hline Distribuição do VA & & & & & \\
\hline Pessoal e encargos (em US\$ mil) & 340.051 & 333.402 & 308.661 & 327.564 & 318.036 \\
\hline \% no VA total & 33,60 & 39,21 & 35,46 & 30,36 & 35,19 \\
\hline Impostos, taxas e contribuições (em US\$ mil) & 357.137 & 290.555 & 306.419 & 308.942 & 285.800 \\
\hline \% no VA total & 35,29 & 34,17 & 35,20 & 28,63 & 31,63 \\
\hline Juros e aluguéis (em US\$ mil) & 155.991 & 169.134 & 173.413 & 418.416 & 158.305 \\
\hline \% no VA total & 15,41 & 19,89 & 19,92 & 38,78 & 17,20 \\
\hline JCP e di videndos (em US\$ mil) & 15.191 & 34.846 & 34.699 & 53.198 & 38.858 \\
\hline \% do VA total & 1,50 & 4,10 & 3,99 & 4,93 & 4,30 \\
\hline Lucros/prejuízos retidos (em US\$ mil) & 143.587 & 22.293 & 47.261 & $(29.185)$ & 102.697 \\
\hline \% do VA total & 14,19 & 2,62 & 5,43 & $(2,70)$ & 11,36 \\
\hline Média de empregados & & 44.614 & 43.989 & 45.828 & 49.222 \\
\hline VA por empregado (em US\$ mil) & & 7,47 & 7,02 & 7,15 & 6,46 \\
\hline
\end{tabular}

Tabela 18- Informações gerais por setores: Construção

\begin{tabular}{l|r|r|r|r|r}
\multicolumn{1}{c|}{ Ano/Informação } & \multicolumn{1}{c|}{$\mathbf{1 9 9 6}$} & \multicolumn{1}{c|}{$\mathbf{1 9 9 7}$} & \multicolumn{1}{c|}{$\mathbf{1 9 9 8}$} & \multicolumn{1}{c|}{$\mathbf{1 9 9 9}$} & \multicolumn{1}{c}{$\mathbf{2 0 0 0}$} \\
\hline VA gerado (em US\$ mil) & 643.894 & 521.811 & 608.833 & 472.746 & 395.275 \\
\hline Participação \% do VA no PIB & 0,11 & 0,09 & 0,10 & 0,09 & 0,07 \\
\hline Participação \% do VA na receita & 60,32 & 47,64 & 48,00 & 60,42 & 43,51 \\
\hline Distribuição do VA & & & & & \\
\hline Pessoal e encargos (em US\$ mil) & 232.126 & 226.703 & 246.603 & 185.115 & 213.788 \\
\hline \% no VA total & 36,05 & 43,45 & 40,50 & 39,16 & 54,09 \\
\hline Impostos, taxas e contribuições (em US\$ mil) & 36.050 & 88.844 & 100.942 & 52.086 & 64.483 \\
\hline \% no VA total & 5,60 & 17,03 & 16,58 & 11,02 & 16,31 \\
\hline Juros e aluguéis (em US\$ mil) & 153.012 & 131.052 & 159.674 & 144.823 & 81.125 \\
\hline \% no VA total & 23,76 & 25,11 & 26,23 & 30,63 & 20,52 \\
\hline JCP e dividendos (em US\$ mil) & - & 3.322 & 33.589 & 3.659 & 13.832 \\
\hline \% do VA total & - & 0,64 & 5,52 & 0,77 & 3,50 \\
\hline Lucros/prejuízos retidos (em US\$ mil) & 222.706 & 71.890 & 68.025 & 87.063 & 22.047 \\
\hline \% do VA total & 34,59 & 13,78 & 11,17 & 18,42 & 5,58 \\
\hline Média de empregados & & 18.616 & 17.977 & 16.848 & 16.523 \\
\hline VA por empregado (em US\$ mil) & & 12,18 & 13,72 & 10,99 & 12,94 \\
\hline
\end{tabular}


Tabela 19- Informações gerais por setores: Diversos

\begin{tabular}{l|r|r|r|r|r}
\multicolumn{1}{c|}{ Ano/Informação } & \multicolumn{1}{c|}{$\mathbf{1 9 9 6}$} & \multicolumn{1}{c|}{$\mathbf{1 9 9 7}$} & \multicolumn{1}{c}{$\mathbf{1 9 9 8}$} & \multicolumn{1}{c}{$\mathbf{1 9 9 9}$} & \multicolumn{1}{c}{$\mathbf{2 0 0 0}$} \\
\hline VA gerado (em US\$ mil) & 93.788 & 95.095 & 99.913 & 103.996 & 89.577 \\
\hline Participação \% do VA no PIB & 0,02 & 0,02 & 0,02 & 0,02 & 0,02 \\
\hline Participação \% do VA na receita & 43,93 & 44,31 & 46,47 & 48,66 & 41,14 \\
\hline Distribuição do VA & & & & & \\
\hline Pessoal e encargos (em US\$ mil) & 26.356 & 25.140 & 24.998 & 21.898 & 24.648 \\
\hline \% no VA total & 28,10 & 26,44 & 25,02 & 21,06 & 27,52 \\
\hline Impostos, taxas e contribuições (em US\$ mil) & 40.110 & 43.804 & 45.365 & 48.416 & 44.626 \\
\hline \% no VA total & 42,77 & 46,06 & 45,40 & 46,56 & 49,82 \\
\hline Juros e aluguéis (em US\$ mil) & 9.866 & 8.883 & 7.936 & 8.680 & 5.806 \\
\hline \% no VA total & 10,52 & 9,34 & 7,94 & 8,35 & 6,48 \\
\hline JCP e dividendos (em US\$ mil) & 7.193 & 3.981 & 3.772 & 3.093 & 1.808 \\
\hline \% do VA total & 7,67 & 4,19 & 3,78 & 2,97 & 2,02 \\
\hline Lucros/prejuízos retidos (em US\$ mil) & 10.263 & 13.287 & 17.842 & 21.909 & 12.689 \\
\hline \% do VA total & 10,94 & 13,97 & 17,86 & 21,07 & 14,17 \\
\hline Média de empregados & & 2.064 & 1.901 & 1.857 & 1.778 \\
\hline VA por empregado (em US\$ mil) & & 12,18 & 13,15 & 11,79 & 13,86 \\
\hline
\end{tabular}

Tabela 20- Informações gerais por setores: Eletroeletrônicos

\begin{tabular}{|c|c|c|c|c|c|}
\hline Ano/Informação & 1996 & 1997 & 1998 & 1999 & 2000 \\
\hline VA gerado (em US\$ mil) & 989.361 & 840.344 & 720.369 & 674.767 & 823.246 \\
\hline Participação \% do VA no PIB & 0,17 & 0,14 & 0,12 & 0,12 & 0,15 \\
\hline Participação \% do VA na receita & 33,38 & 31,03 & 32,60 & 35,60 & 38,66 \\
\hline \multicolumn{6}{|l|}{ Distribuição do VA } \\
\hline Pessoal e encargos (em US\$ mil) & 217.531 & 216.547 & 202.841 & 181.955 & 157.942 \\
\hline$\%$ no VA total & 21,99 & 25,77 & 28,16 & 26,97 & 19,19 \\
\hline Impostos, taxas e contribuições (em US\$ mil) & 417.881 & 343.523 & 314.088 & 136.919 & 305.197 \\
\hline \% no VA total & 42,24 & 40,88 & 43,60 & 20,29 & 37,07 \\
\hline Juros e aluguéis (em US\$ mil) & 128.348 & 129.006 & 212.963 & 613.557 & 317.897 \\
\hline$\%$ no VA total & 12,97 & 15,35 & 29,56 & 90,93 & 38,62 \\
\hline JCP e dividendos (em US\$ mil) & 49.324 & 54.596 & 33.055 & 9.228 & 6.944 \\
\hline$\%$ do VA total & 4,99 & 6,50 & 4,59 & 1,37 & 0,84 \\
\hline Lucros/prejuízos retidos (em US\$ mil) & 176.277 & 96.672 & $(42.578)$ & $(266.892)$ & 35.266 \\
\hline \% do VA total & 17,82 & 11,50 & $(5,91)$ & $(39,55)$ & 4,28 \\
\hline Média de empregados & & 11.918 & 9.926 & 8.899 & 8.927 \\
\hline VA por empregado (em US\$ mil) & & 18,17 & 20,44 & 20,45 & 17,69 \\
\hline
\end{tabular}


Tabela 21- Informações gerais por setores: Farmacêutico

\begin{tabular}{l|r|r|r|r|r}
\multicolumn{1}{c|}{ Ano/Informação } & \multicolumn{1}{c|}{$\mathbf{1 9 9 6}$} & \multicolumn{1}{c|}{$\mathbf{1 9 9 7}$} & \multicolumn{1}{c}{$\mathbf{1 9 9 8}$} & \multicolumn{1}{c}{$\mathbf{1 9 9 9}$} & \multicolumn{1}{c}{$\mathbf{2 0 0 0}$} \\
\hline VA gerado (em US\$ mil) & \multicolumn{1}{c}{279.711} & 283.772 & 307.297 & 256.358 & 210.371 \\
\hline Participação \% do VA no PIB & 0,05 & 0,05 & 0,05 & 0,05 & 0,04 \\
\hline Participação \% do VA na receita & 52,90 & 49,83 & 52,43 & 45,33 & 43,13 \\
\hline Distribuição do VA & & & & & \\
\hline Pessoal e encargos (em US\$ mil) & 59.162 & 69.086 & 69.891 & 67.121 & 69.351 \\
\hline \% no VA total & 21,15 & 24,35 & 22,74 & 26,18 & 32,97 \\
\hline Impostos, taxas e contribuições (em US\$ mil) & 113.770 & 113.828 & 127.386 & 112.873 & 91.464 \\
\hline \% no VA total & 40,67 & 40,11 & 41,45 & 44,03 & 43,48 \\
\hline Juros e aluguéis (em US\$ mil) & 6.136 & 3.760 & 6.240 & 9.736 & 8.481 \\
\hline \% no VA total & 2,19 & 1,33 & 2,03 & 3,80 & 4,03 \\
\hline JCP e dividendos (em US\$ mil) & 31.088 & 23.701 & 16.119 & 19.129 & 16.791 \\
\hline \% do VA total & 11,11 & 8,35 & 5,25 & 7,46 & 7,98 \\
\hline Lucros/prejuízos retidos (em US\$ mil) & 69.555 & 73.397 & 87.661 & 47.499 & 24.284 \\
\hline \% do VA total & 24,87 & 25,86 & 28,53 & 18,53 & 11,54 \\
\hline Média de empregados & & 3.080 & 3.055 & 3.097 & 2.887 \\
\hline VA por empregado (em US\$ mil) & & 22,43 & 22,88 & 21,67 & 24,03 \\
\hline
\end{tabular}

Tabela 22- Informações gerais por setores: Fumo

\begin{tabular}{l|r|r|r|r|r}
\multicolumn{1}{c|}{ Ano/Informação } & \multicolumn{1}{c|}{$\mathbf{1 9 9 6}$} & \multicolumn{1}{c|}{$\mathbf{1 9 9 7}$} & \multicolumn{1}{c|}{$\mathbf{1 9 9 8}$} & \multicolumn{1}{c}{$\mathbf{1 9 9 9}$} & \multicolumn{1}{c}{$\mathbf{2 0 0 0}$} \\
\hline VA gerado (em US\$ mil) & \multicolumn{1}{c}{ (e.775.177 } & \multicolumn{1}{c}{. 521.703} & \multicolumn{1}{c}{3.112 .479} & 2.882 .770 & 2.253 .328 \\
\hline Participação \% do VA no PIB & 0,65 & 0,59 & 0,50 & 0,53 & 0,41 \\
\hline Participação \% do VA na receita & 84,77 & 83,87 & 85,08 & 87,19 & 80,75 \\
\hline Distribuição do VA & & & & & \\
\hline Pessoal e encargos (em US\$ mil) & 146.332 & 139.295 & 114.107 & 95.887 & 93.037 \\
\hline \% no VA total & 3,88 & 3,96 & 3,67 & 3,33 & 4,13 \\
\hline Impostos, taxas e contribuições (em US\$ mil) & 3.287 .047 & 3.038 .360 & 2.602 .229 & 2.227 .947 & 1.843 .108 \\
\hline \% no VA total & 87,07 & 86,28 & 83,61 & 77,28 & 81,79 \\
\hline Juros e aluguéis (em US\$ mil) & 78.606 & 73.300 & 48.065 & 181.093 & 64.381 \\
\hline \% no VA total & 2,08 & 2,08 & 1,54 & 6,28 & 2,86 \\
\hline JCP e dividendos (em US\$ mil) & 175.019 & 203.512 & 327.368 & 377.827 & 252.796 \\
\hline \% do VA total & 4,64 & 5,78 & 10,52 & 13,11 & 11,22 \\
\hline Lucros/prejuízos retidos (em US\$ mil) & 88.173 & 67.236 & 20.710 & 47.499 & 6 \\
\hline \% do VA total & 2,34 & 1,91 & 0,67 & 1,65 & 0,00 \\
\hline Média de empregados & & 8.380 & 7.521 & 6.417 & 5.339 \\
\hline VA por empregado (em US\$ mil) & & 16,62 & 15,17 & 14,94 & 17,43 \\
\hline
\end{tabular}


Tabela 23- Informações gerais por setores: Higiene, limpeza e cosméticos

\begin{tabular}{l|r|r|r|r|r}
\multicolumn{1}{c|}{ Ano/Informação } & \multicolumn{1}{c|}{$\mathbf{1 9 9 6}$} & \multicolumn{1}{c|}{$\mathbf{1 9 9 7}$} & \multicolumn{1}{c|}{$\mathbf{1 9 9 8}$} & \multicolumn{1}{c|}{$\mathbf{1 9 9 9}$} & \multicolumn{1}{c}{$\mathbf{2 0 0 0}$} \\
\hline VA gerado (em US\$ mil) & 176.860 & 173.995 & 180.372 & \multicolumn{1}{c}{306.957} & 197.359 \\
\hline Participação \% do VA no PIB & 0,03 & 0,03 & 0,03 & 0,06 & 0,04 \\
\hline Participação \% do VA na receita & 32,57 & 37,92 & 44,24 & 78,95 & 56,01 \\
\hline Distribuição do VA & & & & & \\
\hline Pessoal e encargos (em US\$ mil) & 57.126 & 55.089 & 51.677 & 42.113 & 35.327 \\
\hline \% no VA total & 32,30 & 31,66 & 28,65 & 13,72 & 17,90 \\
\hline Impostos, taxas e contribuições (em US\$ mil) & 84.357 & 79.958 & 74.394 & 56.256 & 59.646 \\
\hline \% no VA total & 47,70 & 45,95 & 41,24 & 18,33 & 30,22 \\
\hline Juros e aluguéis (em US\$ mil) & 24.401 & 23.908 & 34.343 & 92.625 & 54.375 \\
\hline \% no VA total & 13,80 & 13,74 & 19,04 & 30,18 & 27,55 \\
\hline JCP e dividendos (em US\$ mil) & 1.620 & 1.049 & 14.945 & 24.372 & 7.567 \\
\hline \% do VA total & 0,92 & 0,60 & 8,29 & 7,94 & 3,83 \\
\hline Lucros/prejuízos retidos (em US\$ mil) & 9.356 & 13.991 & 5.013 & 91.591 & 40.444 \\
\hline \% do VA total & 5,29 & 8,04 & 2,78 & 29,84 & 20,49 \\
\hline Média de empregados & & 4.302 & 3.747 & 3.452 & 3.291 \\
\hline VA por empregado (em US\$ mil) & & 12,81 & 13,79 & 12,20 & 10,74 \\
\hline
\end{tabular}

Tabela 24- Informações gerais por setores: Material de construção

\begin{tabular}{l|r|r|r|r|r}
\multicolumn{1}{c|}{ Ano/Informação } & \multicolumn{1}{c|}{$\mathbf{1 9 9 6}$} & \multicolumn{1}{c|}{$\mathbf{1 9 9 7}$} & \multicolumn{1}{c|}{$\mathbf{1 9 9 8}$} & \multicolumn{1}{c}{$\mathbf{1 9 9 9}$} & \multicolumn{1}{c}{$\mathbf{2 0 0 0}$} \\
\hline VA gerado (em US\$ mil) & 449.843 & 455.222 & 531.422 & 594.312 & 614.181 \\
\hline Participação \% do VA no PIB & 0,08 & 0,08 & 0,09 & 0,11 & 0,11 \\
\hline Participação \% do VA na receita & 48,13 & 45,93 & 52,81 & 57,14 & 53,04 \\
\hline Distribuição do VA & & & & & \\
\hline Pessoal e encargos (em US\$ mil) & 138.297 & 128.089 & 124.794 & 122.085 & 111.682 \\
\hline \% no VA total & 30,74 & 28,14 & 23,48 & 20,54 & 18,18 \\
\hline Impostos, taxas e contribuições (em US\$ mil) & 190.803 & 186.003 & 210.755 & 226.806 & 256.955 \\
\hline \% no VA total & 42,42 & 40,86 & 39,66 & 38,16 & 41,84 \\
\hline Juros e aluguéis (em US\$ mil) & 70.791 & 64.871 & 78.636 & 175.690 & 91.766 \\
\hline \% no VA total & 15,74 & 14,25 & 14,80 & 29,56 & 14,94 \\
\hline JCP e dividendos (em US\$ mil) & 58.930 & 37.955 & 38.973 & 46.100 & 60.714 \\
\hline \% do VA total & 13,10 & 8,34 & 7,33 & 7,76 & 9,89 \\
\hline Lucros/prejuízos retidos (em US\$ mil) & $(8.978)$ & 38.304 & 78.264 & 23.631 & 93.064 \\
\hline \% do VA total & $(2,00)$ & 8,41 & 14,73 & 3,98 & 15,15 \\
\hline Média de empregados & & 8.864 & 8.639 & 8.354 & 8.395 \\
\hline VA por empregado (em US\$ mil) & & 14,45 & 14,45 & 14,61 & 13,30 \\
\hline
\end{tabular}


Tabela 25- Informações gerais por setores: Mecânica

\begin{tabular}{l|r|r|r|r|r}
\multicolumn{1}{c|}{ Ano/Informação } & \multicolumn{1}{c|}{$\mathbf{1 9 9 6}$} & \multicolumn{1}{c|}{$\mathbf{1 9 9 7}$} & \multicolumn{1}{c}{$\mathbf{1 9 9 8}$} & \multicolumn{1}{c}{$\mathbf{1 9 9 9}$} & \multicolumn{1}{c}{$\mathbf{2 0 0 0}$} \\
\hline VA gerado (em US\$ mil) & 438.505 & 443.914 & 463.746 & 552.406 & 461.037 \\
\hline Participação \% do VA no PIB & 0,08 & 0,07 & 0,08 & 0,10 & 0,08 \\
\hline Participação \% do VA na receita & 47,55 & 46,28 & 47,74 & 52,05 & 41,74 \\
\hline Distribuição do VA & & & & & \\
\hline Pessoal e encargos (em US\$ mil) & 243.915 & 221.728 & 216.622 & 221.957 & 198.363 \\
\hline \% no VA total & 55,62 & 49,95 & 46,71 & 40,18 & 43,03 \\
\hline Impostos, taxas e contribuições (em US\$ mil) & 106.369 & 102.887 & 106.364 & 92.732 & 114.374 \\
\hline \% no VA total & 24,26 & 23,18 & 22,94 & 16,79 & 24,81 \\
\hline Juros e aluguéis (em US\$ mil) & 44.918 & 56.273 & 58.098 & 204.896 & 82.924 \\
\hline \% no VA total & 10,24 & 12,68 & 12,53 & 37,09 & 17,99 \\
\hline JCP e dividendos (em US\$ mil) & 25.000 & 36.564 & 41.042 & 13.199 & 16.031 \\
\hline \% do VA total & 5,70 & 8,24 & 8,85 & 2,39 & 3,48 \\
\hline Lucros/prejuízos retidos (em US\$ mil) & 18.303 & 26.462 & 41.620 & 19.622 & 49.345 \\
\hline \% do VA total & 4,17 & 5,96 & 8,97 & 3,55 & 10,70 \\
\hline Média de empregados & & 12.487 & 11.929 & 12.551 & 12.949 \\
\hline VA por empregado (em US\$ mil) & & 17,76 & 18,16 & 17,69 & 15,32 \\
\hline
\end{tabular}

Tabela 26- Informações gerais por setores: Mineração

\begin{tabular}{l|r|r|r|r|r}
\multicolumn{1}{c|}{ Ano/Informação } & \multicolumn{1}{c|}{$\mathbf{1 9 9 6}$} & \multicolumn{1}{c|}{$\mathbf{1 9 9 7}$} & \multicolumn{1}{c|}{$\mathbf{1 9 9 8}$} & \multicolumn{1}{c}{$\mathbf{1 9 9 9}$} & \multicolumn{1}{c}{$\mathbf{2 0 0 0}$} \\
\hline VA gerado (em US\$ mil) & 1.696 .683 & 1.843 .123 & 1.971 .910 & 2.645 .659 & 2.138 .827 \\
\hline Participação \% do VA no PIB & 0,29 & 0,31 & 0,32 & 0,49 & 0,38 \\
\hline Participação \% do VA na receita & 56,22 & 60,02 & 61,57 & 69,54 & 54,33 \\
\hline Distribuição do VA & & & & & \\
\hline Pessoal e encargos (em US\$ mil) & 586.680 & 570.231 & 425.803 & 384.438 & 344.343 \\
\hline \% no VA total & 34,58 & 30,94 & 21,59 & 14,53 & 16,10 \\
\hline Impostos, taxas e contribuições (em US\$ mil) & 287.425 & 265.267 & 296.815 & 362.352 & 184.994 \\
\hline \% no VA total & 16,94 & 14,39 & 15,05 & 13,70 & 8,65 \\
\hline Juros e aluguéis (em US\$ mil) & 387.942 & 419.683 & 488.136 & 1.189 .152 & 551.885 \\
\hline \% no VA total & 22,86 & 22,77 & 24,75 & 44,95 & 25,80 \\
\hline JCP e dividendos (em US\$ mil) & 212.078 & 406.771 & 540.459 & 539.214 & 727.217 \\
\hline \% do VA total & 12,50 & 22,07 & 27,41 & 20,38 & 34,00 \\
\hline Lucros/prejuízos retidos (em US\$ mil) & 222.558 & 181.171 & 220.697 & 170.503 & 330.388 \\
\hline \% do VA total & 13,12 & 9,83 & 11,19 & 6,44 & 15,45 \\
\hline Média de empregados & & 18.258 & 15.930 & 15.602 & 15.605 \\
\hline VA por empregado (em US\$ mil) & & 31,23 & 26,73 & 24,64 & 22,07 \\
\hline
\end{tabular}


Tabela 27- Informações gerais por setores: Papel e celulose

\begin{tabular}{l|r|r|r|r|r}
\multicolumn{1}{c|}{ Ano/Informação } & \multicolumn{1}{c|}{$\mathbf{1 9 9 6}$} & \multicolumn{1}{c|}{$\mathbf{1 9 9 7}$} & \multicolumn{1}{c}{$\mathbf{1 9 9 8}$} & \multicolumn{1}{c}{$\mathbf{1 9 9 9}$} & \multicolumn{1}{c}{$\mathbf{2 0 0 0}$} \\
\hline VA gerado (em US\$ mil) & 1.094 .514 & 986.541 & 926.342 & 2.126 .278 & 2.163 .077 \\
\hline Participação \% do VA no PIB & 0,19 & 0,16 & 0,15 & 0,39 & 0,39 \\
\hline Participação \% do VA na receita & 43,01 & 43,30 & 39,93 & 65,65 & 62,95 \\
\hline Distribuição do VA & & & & & \\
\hline Pessoal e encargos (em US\$ mil) & 348.472 & 336.341 & 356.527 & 352.199 & 311.382 \\
\hline \% no VA total & 31,84 & 34,09 & 38,49 & 16,56 & 14,40 \\
\hline Impostos, taxas e contribuições (em US\$ mil) & 374.909 & 257.687 & 183.754 & 280.166 & 565.740 \\
\hline \% no VA total & 34,25 & 26,12 & 19,84 & 13,18 & 26,15 \\
\hline Juros e aluguéis (em US\$ mil) & 242.685 & 351.989 & 504.760 & 1.368 .361 & 506.082 \\
\hline \% no VA total & 22,17 & 35,68 & 54,49 & 64,35 & 23,40 \\
\hline JCP e dividendos (em US\$ mil) & 55.279 & 18.078 & 9.642 & 70.711 & 160.386 \\
\hline \% do VA total & 5,05 & 1,83 & 1,04 & 3,33 & 7,41 \\
\hline Lucros/prejuízos retidos (em US\$ mil) & 73.169 & 22.446 & $(128.341)$ & 58.841 & 619.487 \\
\hline \% do VA total & 6,69 & 2,28 & $(13,85)$ & 2,58 & 28,64 \\
\hline Média de empregados & & 20.195 & 19.385 & 19.095 & 18.549 \\
\hline VA por empregado (em US\$ mil) & & 16,65 & 18,39 & 18,44 & 16,79 \\
\hline
\end{tabular}

Tabela 28- Informações gerais por setores: Plásticos e borrachas

\begin{tabular}{l|r|r|r|r|r}
\multicolumn{1}{c|}{ Ano/Informação } & \multicolumn{1}{c|}{$\mathbf{1 9 9 6}$} & \multicolumn{1}{c|}{$\mathbf{1 9 9 7}$} & \multicolumn{1}{c|}{$\mathbf{1 9 9 8}$} & \multicolumn{1}{c}{$\mathbf{1 9 9 9}$} & \multicolumn{1}{c}{$\mathbf{2 0 0 0}$} \\
\hline VA gerado (em US\$ mil) & 27.606 & 30.226 & \multicolumn{1}{c}{32.660} & 26.667 & 31.928 \\
\hline Participação \% do VA no PIB & 0,01 & 0,01 & 0,01 & 0,00 & 0,01 \\
\hline Participação \% do VA na receita & 36,07 & 40,17 & 47,50 & 36,84 & 41,62 \\
\hline Distribuição do VA & & & & & \\
\hline Pessoal e encargos (em US\$ mil) & 11.032 & 13.890 & 13.009 & 8.333 & 10.051 \\
\hline \% no VA total & 39,96 & 34,09 & 39,83 & 31,25 & 31,48 \\
\hline Impostos, taxas e contribuições (em US\$ mil) & 13.673 & 11.665 & 15.313 & 14.648 & 16.321 \\
\hline \% no VA total & 49,53 & 26,12 & 46,89 & 54,93 & 51,12 \\
\hline Juros e aluguéis (em US\$ mil) & 2.596 & 4.031 & 3.222 & 4.051 & 4.562 \\
\hline \% no VA total & 9,40 & 35,68 & 9,87 & 15,19 & 14,29 \\
\hline JCP e dividendos (em US\$ mil) & - & 60 & 203 & 147 & 206 \\
\hline \% do VA total & - & 1,83 & 0,62 & 0,55 & 0,65 \\
\hline Lucros/prejuízos retidos (em US\$ mil) & 305 & 580 & 913 & $(512)$ & 788 \\
\hline \% do VA total & 1,10 & 2,28 & 2,80 & $(1,92)$ & 2,47 \\
\hline Média de empregados & & 2.038 & 1.889 & 1.852 & 2.027 \\
\hline VA por empregado (em US\$ mil) & & 6,82 & 6,89 & 4,50 & 4,96 \\
\hline
\end{tabular}


Tabela 29- Informações gerais por setores: Química e petroquímica

\begin{tabular}{l|r|r|r|r|r}
\multicolumn{1}{c|}{ Ano/Informação } & \multicolumn{1}{c|}{$\mathbf{1 9 9 6}$} & \multicolumn{1}{c|}{$\mathbf{1 9 9 7}$} & \multicolumn{1}{c}{$\mathbf{1 9 9 8}$} & \multicolumn{1}{c}{$\mathbf{1 9 9 9}$} & \multicolumn{1}{c}{$\mathbf{2 0 0 0}$} \\
\hline VA gerado (em US\$ mil) & 10.532 .402 & 12.507 .417 & 13.110 .564 & 16.675 .756 & 21.495 .614 \\
\hline Participação \% do VA no PIB & 1,83 & 2,09 & 2,12 & 3,08 & 3,87 \\
\hline Participação \% do VA na receita & 52,01 & 60,59 & 65,98 & 65,02 & 63,39 \\
\hline Distribuição do VA & & & & & \\
\hline Pessoal e encargos (em US\$ mil) & 2.157 .854 & 2.015 .850 & 2.022 .836 & 1.599 .291 & 1.406 .213 \\
\hline \% no VA total & 20,49 & 16,12 & 15,43 & 9,59 & 6,54 \\
\hline Impostos, taxas e contribuições (em US\$ mil) & 6.614 .919 & 7.962 .956 & 8.052 .872 & 8.204 .856 & 11.790 .846 \\
\hline \% no VA total & 62,81 & 63,67 & 61,42 & 49,20 & 54,85 \\
\hline Juros e aluguéis (em US\$ mil) & 1.293 .924 & 1.531 .769 & 1.951 .360 & 5.772 .737 & 3.010 .757 \\
\hline \% no VA total & 12,29 & 12,25 & 14,88 & 34,62 & 14,01 \\
\hline JCP e dividendos (em US\$ mil) & 199.864 & 19.087 & 38.965 & 542.078 & 1.352 .331 \\
\hline \% do VA total & 1,90 & 0,15 & 0,30 & 3,25 & 6,29 \\
\hline Lucros/prejuízos retidos (em US\$ mil) & 265.841 & 977.755 & 1.044 .531 & 556.794 & 3.935 .467 \\
\hline \% do VA total & 2,52 & 7,82 & 7,97 & 3,34 & 18,31 \\
\hline Média de empregados & & $52.074,00$ & $49.168,00$ & $46.262,00$ & $45.740,00$ \\
\hline VA por empregado (em US\$ mil) & & 38,71 & 41,14 & 34,57 & 30,74 \\
\hline
\end{tabular}

Tabela 30- Informações gerais por setores: Serviço de transporte

\begin{tabular}{|c|c|c|c|c|c|}
\hline Ano/Informação & 1996 & 1997 & 1998 & 1999 & 2000 \\
\hline VA gerado (em US\$ mil) & 614.454 & 695.535 & 716.147 & 765.872 & 722.194 \\
\hline Participação \% do VA no PIB & 0,11 & 0,12 & 0,12 & 0,14 & 0,13 \\
\hline Participação \% do VA na receita & 50,29 & 49,09 & 48,51 & 48,60 & 39,35 \\
\hline \multicolumn{6}{|l|}{ Distribuição do VA } \\
\hline Pessoal e encargos (em US\$ mil) & 456.743 & 453.785 & 508.304 & 540.147 & 531.210 \\
\hline \% no VA total & 74,33 & 65,24 & 70,98 & 70,53 & 73,56 \\
\hline Impostos, taxas e contribuições (em US\$ mil) & 162.474 & 206.253 & 209.015 & 220.586 & 317.151 \\
\hline$\%$ no VA total & 26,44 & 29,65 & 29,19 & 28,80 & 43,91 \\
\hline Juros e aluguéis (em US\$ mil) & 446.203 & 292.273 & 104.841 & 269.511 & 230.050 \\
\hline$\%$ no VA total & 72,62 & 42,02 & 14,64 & 35,19 & 31,85 \\
\hline JCP e dividendos (em US\$ mil) & 4.049 & 5.607 & 12.815 & 12.104 & 8.854 \\
\hline$\%$ do VA total & 0,66 & 0,81 & 1,79 & 1,58 & 1,23 \\
\hline Lucros/prejuízos retidos (em US\$ mil) & $(455.015)$ & $(262.383)$ & $(118.828)$ & $(276.476)$ & $(365.071)$ \\
\hline \% do VA total & $(74,05)$ & $(37,72)$ & $(16,59)$ & $(36,10)$ & $(50,55)$ \\
\hline Média de empregados & & 36.774 & 37.226 & 37.169 & 38.962 \\
\hline VA por empregado (em US\$ mil) & & 12,34 & 13,65 & 14,53 & 13,63 \\
\hline
\end{tabular}


Tabela 31- Informações gerais por setores: Serviços diversos

\begin{tabular}{l|r|r|r|r|r}
\multicolumn{1}{c|}{ Ano/Informação } & \multicolumn{1}{c|}{$\mathbf{1 9 9 6}$} & \multicolumn{1}{c|}{$\mathbf{1 9 9 7}$} & \multicolumn{1}{c}{$\mathbf{1 9 9 8}$} & \multicolumn{1}{c}{$\mathbf{1 9 9 9}$} & \multicolumn{1}{c}{$\mathbf{2 0 0 0}$} \\
\hline VA gerado (em US\$ mil) & 158.611 & 164.999 & 172.978 & 170.779 & 178.846 \\
\hline Participação \% do VA no PIB & 0,03 & 0,03 & 0,03 & 0,03 & 0,03 \\
\hline Participação \% do VA na receita & 55,69 & 54,39 & 53,50 & 55,29 & 53,68 \\
\hline Distribuição do VA & & & & & \\
\hline Pessoal e encargos (em US\$ mil) & 97.060 & 95.694 & 120.784 & 119.877 & 114.401 \\
\hline \% no VA total & 61,19 & 58,00 & 69,83 & 70,19 & 63,97 \\
\hline Impostos, taxas e contribuições (em US\$ mil) & 24.233 & 30.821 & 28.513 & 28.424 & 28.358 \\
\hline \% no VA total & 15,28 & 18,68 & 16,48 & 16,64 & 15,86 \\
\hline Juros e aluguéis (em US\$ mil) & 4.984 & 6.713 & 10.052 & 21.949 & 11.763 \\
\hline \% no VA total & 3,14 & 4,07 & 5,81 & 12,85 & 6,58 \\
\hline JCP e dividendos (em US\$ mil) & 14.210 & 9.739 & 9.763 & 8.066 & 9.389 \\
\hline \% do VA total & 8,96 & 5,90 & 5,64 & 4,72 & 5,25 \\
\hline Lucros/prejuízos retidos (em US\$ mil) & 18.124 & 22.032 & 3.866 & $(7.537)$ & 14.935 \\
\hline \% do VA total & 11,43 & 13,35 & 2,23 & $(4,41)$ & 8,35 \\
\hline Média de empregados & & 4.953 & 5.158 & 5.284 & 5.320 \\
\hline VA por empregado (em US\$ mil) & & 19,32 & 23,42 & 22,69 & 21,51 \\
\hline
\end{tabular}

Tabela 32- Informações gerais por setores: Serviços públicos

\begin{tabular}{l|r|r|r|r|r}
\multicolumn{1}{c|}{ Ano/Informação } & \multicolumn{1}{c|}{$\mathbf{1 9 9 6}$} & \multicolumn{1}{c|}{$\mathbf{1 9 9 7}$} & \multicolumn{1}{c|}{$\mathbf{1 9 9 8}$} & \multicolumn{1}{c}{$\mathbf{1 9 9 9}$} & \multicolumn{1}{c}{$\mathbf{2 0 0 0}$} \\
\hline VA gerado (em US\$ mil) & 12.790 .519 & 14.783 .290 & 12.720 .534 & 12.968 .857 & 10.798 .855 \\
\hline Participação \% do VA no PIB & 2,22 & 2,47 & 2,06 & 2,39 & 1,94 \\
\hline Participação \% do VA na receita & 54,20 & 59,25 & 54,58 & 56,94 & 48,36 \\
\hline Distribuição do VA & & & & & \\
\hline Pessoal e encargos (em US\$ mil) & 4.997 .920 & 5.459 .767 & 4.026 .533 & 3.293 .445 & 2.868 .228 \\
\hline \% no VA total & 39,08 & 36,93 & 31,65 & 25,40 & 26,56 \\
\hline Impostos, taxas e contribuições (em US\$ mil) & 4.596 .041 & 4.738 .635 & 4.040 .703 & 4.250 .865 & 4.648 .656 \\
\hline \% no VA total & 35,93 & 32,05 & 31,77 & 32,78 & 43,05 \\
\hline Juros e aluguéis (em US\$ mil) & 2.221 .597 & 2.287 .296 & 3.034 .110 & 5.229 .603 & 2.474 .363 \\
\hline \% no VA total & 17,37 & 15,47 & 23,85 & 40,32 & 22,91 \\
\hline JCP e dividendos (em US\$ mil) & 363.754 & 894.836 & 1.399 .115 & 348.159 & 773.917 \\
\hline \% do VA total & 2,84 & 6,05 & 11,00 & 2,68 & 7,17 \\
\hline Lucros/prejuízos retidos (em US\$ mil) & 611.207 & 1.402 .756 & 220.073 & $(153.215)$ & 33.691 \\
\hline \% do VA total & 4,78 & 9,49 & 1,73 & $(1,18)$ & 0,31 \\
\hline Média de empregados & & 206.056 & 187.624 & 178.790 & 173.720 \\
\hline VA por empregado (em US\$ mil) & & 26,50 & 21,46 & 18,42 & 16,51 \\
\hline
\end{tabular}


Tabela 33- Informações gerais por setores: Siderurgia e metalurgia

\begin{tabular}{l|r|r|r|r|r}
\multicolumn{1}{c|}{ Ano/Informação } & \multicolumn{1}{c|}{$\mathbf{1 9 9 6}$} & \multicolumn{1}{c|}{$\mathbf{1 9 9 7}$} & \multicolumn{1}{c}{$\mathbf{1 9 9 8}$} & \multicolumn{1}{c}{$\mathbf{1 9 9 9}$} & \multicolumn{1}{c}{$\mathbf{2 0 0 0}$} \\
\hline VA gerado (em US\$ mil) & 1.426 .049 & 1.877 .511 & 1.713 .633 & 2.319 .179 & 2.959 .012 \\
\hline Participação \% do VA no PIB & 0,25 & 0,31 & 0,28 & 0,43 & 0,53 \\
\hline Participação \% do VA na receita & 37,75 & 46,85 & 46,63 & 57,10 & 69,28 \\
\hline Distribuição do VA & & & & & \\
\hline Pessoal e encargos (em US\$ mil) & 692.134 & 670.531 & 570.922 & 497.010 & 483.156 \\
\hline \% no VA total & 48,54 & 35,71 & 33,32 & 21,43 & 16,33 \\
\hline Impostos, taxas e contribuições (em US\$ mil) & 435.725 & 557.073 & 523.300 & 641.762 & 767.660 \\
\hline \% no VA total & 30,55 & 29,67 & 30,54 & 27,67 & 25,94 \\
\hline Juros e aluguéis (em US\$ mil) & 211.231 & 350.602 & 378.749 & 1.158 .565 & 511.585 \\
\hline \% no VA total & 14,81 & 18,67 & 22,10 & 49,96 & 17,29 \\
\hline JCP e dividendos (em US\$ mil) & 115.332 & 178.833 & 178.672 & 160.382 & 697.967 \\
\hline \% do VA total & 8,09 & 9,53 & 10,43 & 6,92 & 23,59 \\
\hline Lucros/prejuízos retidos (em US\$ mil) & $(28.373)$ & 120.472 & 61.990 & $(138.540)$ & 498.644 \\
\hline \% do VA total & $(1,99)$ & 6,42 & 3,62 & $(5,97)$ & 16,85 \\
\hline Média de empregados & & 30.988 & 29.117 & 27.906 & 27.994 \\
\hline VA por empregado (em US\$ mil) & & 21,64 & 19,61 & 17,81 & 17,26 \\
\hline
\end{tabular}

Tabela 34- Informações gerais por setores: Tecnologia e computação

\begin{tabular}{l|r|r|r|r|r}
\multicolumn{1}{c|}{ Ano/Informação } & \multicolumn{1}{c|}{$\mathbf{1 9 9 6}$} & \multicolumn{1}{c|}{$\mathbf{1 9 9 7}$} & \multicolumn{1}{c|}{$\mathbf{1 9 9 8}$} & \multicolumn{1}{c}{$\mathbf{1 9 9 9}$} & \multicolumn{1}{c}{$\mathbf{2 0 0 0}$} \\
\hline VA gerado (em US\$ mil) & \multicolumn{1}{c|}{381.237} & \multicolumn{1}{c}{381.107} & 401.837 & 372.724 & 391.927 \\
\hline Participação \% do VA no PIB & 0,07 & 0,06 & 0,07 & 0,07 & 0,07 \\
\hline Participação \% do VA na receita & 58,56 & 54,34 & 56,74 & 53,06 & 54,86 \\
\hline Distribuição do VA & & & & & \\
\hline Pessoal e encargos (em US\$ mil) & 287.176 & 255.510 & 272.453 & 248.620 & 218.000 \\
\hline \% no VA total & 75,33 & 67,04 & 67,80 & 66,70 & 55,62 \\
\hline Impostos, taxas e contribuições (em US\$ mil) & 81.325 & 104.865 & 104.989 & 100.725 & 129.085 \\
\hline \% no VA total & 21,33 & 27,52 & 26,13 & 27,02 & 32,94 \\
\hline Juros e aluguéis (em US\$ mil) & 22.168 & 15.932 & 15.842 & 16.502 & 15.239 \\
\hline \% no VA total & 5,81 & 4,18 & 3,94 & 4,43 & 3,89 \\
\hline JCP e dividendos (em US\$ mil) & 830 & - & 4.366 & 1.529 & 2.263 \\
\hline \% do VA total & 0,22 & - & 1,09 & 0,41 & 0,58 \\
\hline Lucros/prejuízos retidos (em US\$ mil) & $(10.262)$ & 4.800 & 4.187 & 5.348 & 27.340 \\
\hline \% do VA total & $(2,69)$ & 1,26 & 1,04 & 1,43 & 6,98 \\
\hline Média de empregados & & 10.515 & 10.328 & 10.130 & 9.718 \\
\hline VA por empregado (em US\$ mil) & & 24,30 & 26,38 & 24,54 & 22,43 \\
\hline
\end{tabular}


Tabela 35- Informações gerais por setores: Telecomunicações

\begin{tabular}{l|r|r|r|r|r}
\multicolumn{1}{c|}{ Ano/Informação } & \multicolumn{1}{c|}{$\mathbf{1 9 9 6}$} & \multicolumn{1}{c|}{$\mathbf{1 9 9 7}$} & \multicolumn{1}{c}{$\mathbf{1 9 9 8}$} & \multicolumn{1}{c}{$\mathbf{1 9 9 9}$} & \multicolumn{1}{c}{$\mathbf{2 0 0 0}$} \\
\hline VA gerado (em US\$ mil) & 1.333 .143 & 1.372 .701 & 1.832 .995 & 2.043 .382 & 2.337 .944 \\
\hline Participação \% do VA no PIB & 0,23 & 0,23 & 0,30 & 0,38 & 0,42 \\
\hline Participação \% do VA na receita & 65,83 & 63,96 & 48,95 & 47,38 & 46,44 \\
\hline Distribuição do VA & & & & & \\
\hline Pessoal e encargos (em US\$ mil) & 462.722 & 387.463 & 737.978 & 235.536 & 224.289 \\
\hline \% no VA total & 34,71 & 28,23 & 40,26 & 11,53 & 9,59 \\
\hline Impostos, taxas e contribuições (em US\$ mil) & 443.994 & 504.395 & 828.121 & 1.116 .061 & 1.468 .320 \\
\hline \% no VA total & 33,30 & 36,74 & 45,18 & 54,62 & 62,80 \\
\hline Juros e aluguéis (em US\$ mil) & 104.299 & 106.374 & 157.470 & 453.797 & 307.401 \\
\hline \% no VA total & 7,82 & 7,75 & 8,59 & 22,21 & 13,15 \\
\hline JCP e dividendos (em US\$ mil) & 166.048 & 226.922 & 32.329 & 111.912 & 144.807 \\
\hline \% do VA total & 12,46 & 16,53 & 1,76 & 5,48 & 6,19 \\
\hline Lucros/prejuízos retidos (em US\$ mil) & 156.080 & 147.547 & 77.097 & 126.076 & 193.127 \\
\hline \% do VA total & 11,71 & 10,75 & 4,21 & 6,17 & 8,26 \\
\hline Média de empregados & & 12.070 & 10.533 & 9.242 & 8.950 \\
\hline VA por empregado (em US\$ mil) & & 32,10 & 70,07 & 25,49 & 25,06 \\
\hline
\end{tabular}

Do número médio de postos de trabalho ao longo do período, 4 setores respondem por mais de $50 \%$ dessas vagas, conforme destacado na Tabela 36.

Tabela 36 - Número médio de empregados e percentual dos setores responsáveis por mais de $50 \%$ das vagas no período

\begin{tabular}{l|r|r|r|r|r|r|r|r}
\hline \multicolumn{1}{c|}{ Setores/Ano } & \multicolumn{1}{c|}{$\mathbf{1 9 9 7}$} & \multicolumn{1}{c|}{$\boldsymbol{1}$} & $\mathbf{1 9 9 8}$ & \multicolumn{1}{c|}{$\boldsymbol{1}$} & $\mathbf{1 9 9 9}$ & \multicolumn{1}{c}{} & \multicolumn{1}{c|}{$\mathbf{2 0 0 0}$} & \multicolumn{1}{c}{} \\
\hline Serviços públicos & 206.056 & 33,31 & 187.624 & 32,01 & 178.790 & 31,27 & 173.720 & 30,33 \\
\hline Química e petroquímica & 52.074 & 8,42 & 49.168 & 8,39 & 46.262 & 8,09 & 45.740 & 7,99 \\
\hline Confecções e têxteis & 44.614 & 7,21 & 43.989 & 7,50 & 45.828 & 8,02 & 49.222 & 8,59 \\
\hline Alimentos & 36.245 & 5,86 & 35.711 & 6,09 & 35.876 & 6,28 & 35.987 & 6,28 \\
\hline
\end{tabular}

A evolução da média de empregados desses 4 setores, ao longo do período, encontrase demonstrada no Gráfico 47, onde se observa grande predominância dos serviços públicos, acompanhado, a grande distância, pelos outros 3 setores (química e petroquímica, confecções e têxteis e alimentos), os quais mantém, praticamente, o mesmo nível e variação durante o período. 
Gráfico 47- Média de empregados dos maiores empregadores de 1997 a 2000

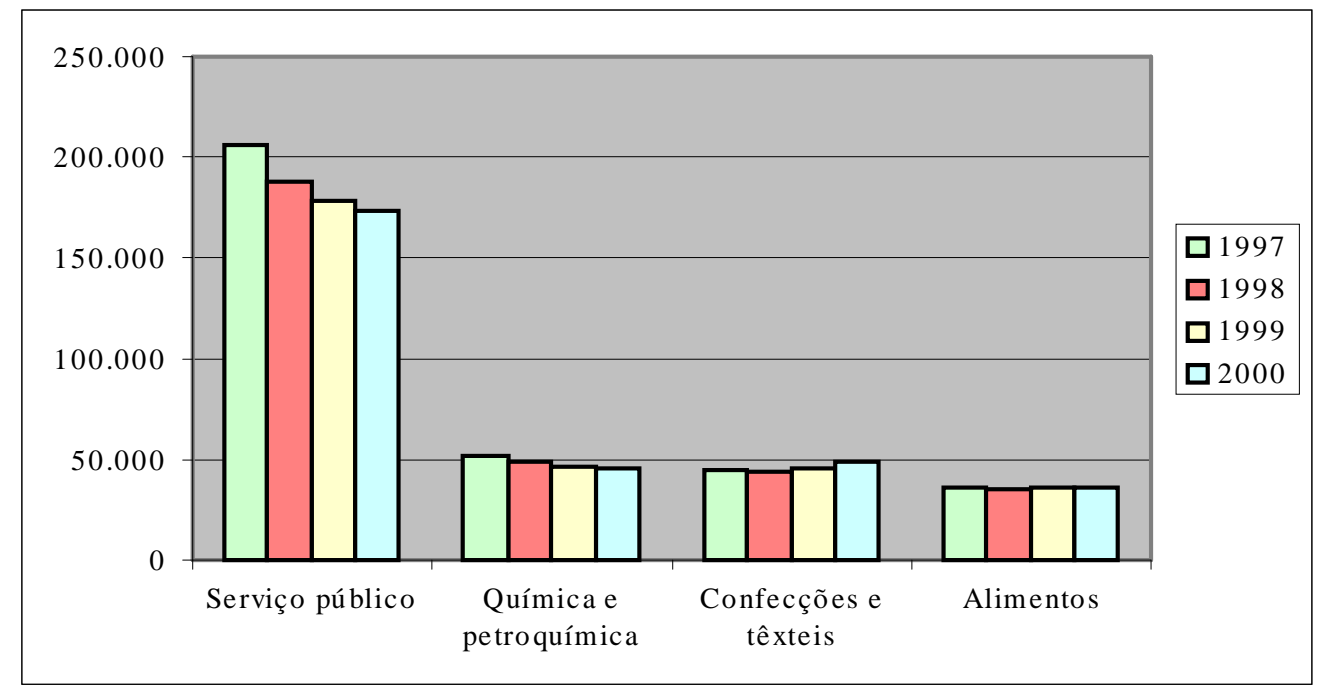

Finalmente, os setores que tiveram maior e menor valor adicionado por empregado, ao longo do período, foram, respectivamente: em 1997, química e petroquímica 38,71 mil dólares e plásticos e borrachas 6,82 mil; em 1998, telecomunicações 70,07 mil e plásticos e borrachas com 6,89 mil; em 1999, química e petroquímica 34,57 mil e plásticos e borrachas 4,5 mil; e em 2000, química e petroquímica 30,74 mil e plásticos e borrachas 4,96 mil. O Gráfico 48 mostra essa disparidade.

\section{Gráfico 48- Setores com maior e menor distribuição de VA por empregado}

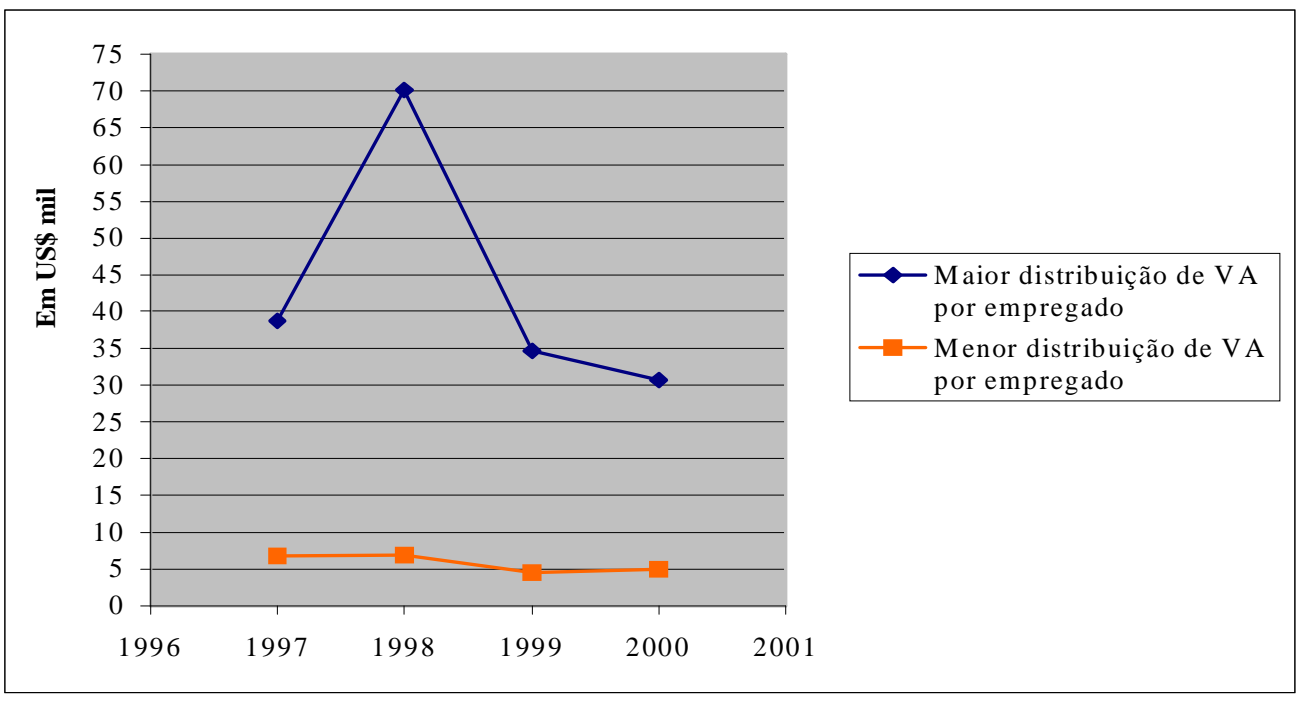


Com exceção do exercício de 1998, o setor química e petroquímica sempre prevaleceu como maior distribuidor de valor adicionado por empregado. Enquanto o menor esteve, em todos os períodos, sob a responsabilidade de plásticos e borrachas.

Partindo-se para a análise individual de cada setor, ao longo do período, algumas constatações são possíveis.

Dos 25 setores analisados, 11 apresentaram decréscimo na geração de riqueza em 2000, comparativamente ao ano de 1996. Em alguns deles esse decréscimo se apresentou bastante expressivo, cerca de 1,84 bilhões de dólares no total, como é o caso do setor de fumo com 40,31\%, o de construção com $38,61 \%$ e o farmacêutico com $24,79 \%$. A participação percentual do valor adicionado desses 3 setores na sua receita, assim como a própria receita do período, também apresentou queda.

Dos setores que apresentaram valor adicionado ascendente, os mais significativos foram: siderurgia e metalurgia com 107,5\%, química e petroquímica com 104,09\%, papel e celulose com 97,63\%, e telecomunicações com 75,37\%. Desses, apenas o setor de telecomunicações apresentou queda na participação percentual do valor adicionado na receita.

Apenas 5 setores aumentaram o valor em dólares de distribuição de sua riqueza para os empregados no ano de 2000 em relação ao de 1996. Do total de 13,09 bilhões de dólares distribuído aos empregados pelas 198 empresas participantes da amostra em 1996, 13,23 bilhões em 1997, 11,91 bilhões em 1998, 10,03 bilhões em 1999 e 9,07 bilhões em 2000, esses 5 setores responderam por 7,39\%, 7,6\%, 9,15\%, 10,99\% e $11,86 \%$, respectivamente. Foram esses os 5 setores: comércio varejista 1,55\%, comunicações $5,58 \%$, farmacêutico $17,22 \%$, serviços diversos $17,87 \%$ e serviços de transporte $16,31 \%$.

Dos setores que apresentaram queda no valor em dólares distribuído aos empregados, 8 sofreram decréscimo superior a 30\% de 2000 em relação a 1996: telecomunicações $51,53 \%$, serviços públicos $42,61 \%$, mineração $41,31 \%$, bebidas $40,29 \%$, higiene, 
limpeza e cosméticos $38,16 \%$, fumo $36,42 \%$, química e petroquímica $34,83 \%$ e siderurgia e metalurgia $30,19 \%$. Esses setores respondem por $70,74 \%$ do total distribuído aos empregados pelas empresas da amostra em 1996, 71,2\% em 1997, 67,42\% em 1998, 62,91\% em 1999 e 61,3\% em 2000. Destes, apenas o setor de serviços públicos e o de fumo também apresentaram redução na geração de riqueza no mesmo período.

Quanto ao valor percentual de distribuição da riqueza para os empregados, constatou-se acréscimo de 1996 para 2000 em 8 setores: construção, de 36,05\% do valor adicionado total para 54,09\% desse valor; atacado e comércio exterior, de $15,35 \%$ para $16,82 \%$; confecções e têxteis, de $33,6 \%$ para $35,19 \%$; fumo, de $3,88 \%$ para $4,13 \%$; comércio varejista, de $39,98 \%$ para $40,87 \%$; comunicações, de $72,71 \%$ para $83,34 \%$; farmacêutico, de $21,15 \%$ para $32,97 \%$; e serviços diversos, de $61,19 \%$ para $63,97 \%$. Observa-se que, dos 8 , apenas o setor de comunicações apresentou aumento também na participação percentual do valor adicionado sobre a receita.

Sete setores apresentaram aumento na média dos postos de trabalho em 2000 comparado a 1997, num total de 15.582 vagas assim distribuídas: serviços de transporte 2.188, mecânica 462, serviços diversos 367, atacado e comércio exterior 2.962 , confecções e têxteis 4.608 , comunicações 115 e comércio varejista 4.880 . No ano de 2000, da média de 572.770 pessoas empregadas nas empresas da amostra, 28,68\% (164.284) pertenciam a esses setores; em 1999, das 571.698, 27,06\% (154.694), em 1998 de 586.214, 25,60\% (150.068); e em 1997 de 618.624, 24,04\% (148.702).

Dos 18 setores que diminuíram vagas de 1997 para 2000 - 61.435 vagas a menos no total - os maiores decréscimos foram: fumo 36,29\% (3.041), telecomunicações 25,85\% (3.120), eletroeletrônicos 25,1\% (2.991), higiene, limpeza e cosméticos 23,5\% (1.011), serviços públicos 15,69\% (32.336), mineração 14,53\% (2.653), diversos $13,85 \%$ (286), bebidas $13,69 \%$ (1.193) e química e petroquímica $12,16 \%$ (6.334). Esses 9 setores foram responsáveis, em 1997, por 323.837 (52,35\%) dos 618.624 postos de trabalho da amostra; em 1998, por $294.464(50,23 \%)$ dos 586.214 ; 
em 1999, por $279.119(48,82 \%)$ dos 571.698; e em 2000, por $270.872(47,29 \%)$ dos 572.770. Só o setor de serviços públicos empregava 173.720 (30,33\%) em 2000, $178.790(31,27 \%)$ em 1999, $187.624(32,01 \%)$ em 1998 e $206.056(33,31 \%)$ em 1997.

São vários os fatores que provocam a diminuição de postos de trabalho. No caso do Brasil, especificamente, pode-se citar: a abertura da economia que colocou o país no meio da globalização - tanto pela entrada de bens de fora ameaçando destruir os empregos de dentro, quanto pelas dificuldades em vender os bens no mercado internacional por um bom preço; o avanço da tecnologia que aumenta a produtividade e provoca desemprego, mesmo assumindo que existam compensações; as privatizações ocorridas; a falta ou a deficiência no crescimento econômico, observada nos últimos anos; e ainda a baixa qualificação da força de trabalho.

Segundo Pastore ${ }^{154}$ :

'O avanço da tecnologia que aumenta a produtividade, provoca desemprego localizado e um forte deslocamento de mão-de-obra de uma área para outra. Muita gente precisa ser reciclada, ampliar seu universo de conhecimentos e aprender novas habilidades. Para tudo isso, a "treinabilidade" é essencial. Só pode ser treinado ou retreinado quem tem educação, pois é esta que garante aprender continuamente.

No Brasil faltam empregos para acomodar os brasileiros que precisam trabalhar. Ao mesmo tempo, faltam trabalhadores para os empregos decorrentes da revolução tecnológica. A força de trabalho no Brasil tem baixa qualificação - só 3,5 anos de escola. Isso é muito pouco para enfrentar e absorver as mudanças que ocorrem nos sistemas produtivos.”

Além do desemprego provocado pelos fatores citados, um outro ponto a ser observado é o crescimento natural da população versus a criação de novos postos de trabalho. A cada ano, cresce o número de pessoas que chegam ao mercado de trabalho. Seria necessário criar novas vagas, apenas para suprir esses novos aspirantes a empregados, sem contar com os que perdem seus empregos. Entretanto, conforme afirma Pastore ${ }^{155}$, "A criação de empregos ficou muito cara. Nos países

\footnotetext{
${ }^{154}$ PASTORE, José. A agonia do emprego. São Paulo: LTr, 1997. Prefácio

155 op. cit. p. 15
} 
mais avançados gerar um emprego custa, em média, US\$100 mil em termos de investimentos. Isso se deve, em grande parte, ao custo das novas tecnologias e das medidas de proteção ambiental”. S eria o caso de se procurar saber, então, o quanto custa para a sociedade um desempregado, não se esquecendo de embutir nesse custo, além dos gastos com o serviço social, aqueles provenientes do aumento da violência e da ociosidade.

Quanto ao valor adicionado distribuído por empregado, observa-se que apenas 8 setores apresentaram elevação de 1997 para 2000: papel e celulose 0,84\%, farmacêutico $7,13 \%$, construção $6,24 \%$, fumo $4,87 \%$, diversos $13,79 \%$, serviços de transporte $10,45 \%$, serviços diversos $11,34 \%$ e comunicações $2,05 \%$. Entretanto, apenas 3 desses setores apresentaram, também, acréscimo no valor total distribuído a pessoal e encargos, e no número médio de empregados: comunicações, serviço de transporte e serviços diversos, significando que houve aumento real no valor adicionado por empregado e no número de postos de trabalho.

E apenas 2 tiveram, ainda, aumento no percentual de valor adicionado distribuído a pessoal e encargos: comunicações e serviços diversos. Os outros 5 setores apresentaram queda nos postos de trabalho e maior distribuição aos empregados remanescentes, ou seja, apenas transferiu-se valor adicionado dos empregados que permaneceram nas empresas.

Em 13 setores observou-se queda tanto nos postos de trabalho quanto no valor adicionado distribuído por empregado, sendo que os que apresentaram maior queda neste último foram: serviços públicos 37,7\% (fruto da falta de reajuste desde 1994), mineração $29,33 \%$, plásticos e borrachas $27,27 \%$, telecomunicações $21,93 \%$, química e petroquímica $20,59 \%$ e siderurgia e metalurgia $20,24 \%$. Isso demonstra menos vagas com salário menor. Nos setores de atacado e comércio exterior, mecânica, confecções e têxteis e comércio varejista, houve crescimento na média de empregados e diminuição no valor adicionado distribuído a cada um deles, aumentou-se vagas, mas com prejuízo de salários dos empregados que já estavam na empresa. 
Ainda quanto à análise setorial, cabem duas observações. A primeira diz respeito a migração de trabalhadores que perdem o emprego para novas modalidades de trabalho, como o serviço autônomo. Quando setores como, construção, fumo, farmacêutico, alimentos e diversos diminuem, sistematicamente, o número médio de empregados ao longo do período, o valor em dólares da riqueza criada e também a participação percentual do valor adicionado na receita, essa diminuição nos postos de trabalho, apesar de real, pode estar sendo apenas transferida para o trabalho autônomo, por meio da terceirização.

Segundo Pastore ${ }^{156}$, esse é o trabalho do futuro:

'O trabalho do futuro não terá nada de fixo, específico, contínuo ou concentrado numa empresa. Ao contrário. Com o avanço acelerado das novas tecnologias e com a individualização das demandas, as grandes empresas, com raras exceções, serão forçadas a atomizar sua produção, subcontratando atividades para pequenas empresas e para profissionais autônomos".

O futuro pode ter chegado, mas a queda nos níveis de emprego pode estar apenas agravando o trabalho informal e o desemprego, e não se transferindo para o trabalho autônomo.

A segunda questão é observada quando há diminuição tanto do número médio de empregados ao longo do período quanto do valor distribuído para pessoal e encargos e, ainda, do valor adicionado distribuído por empregado, e se refere aos cargos de chefia. Para Pastore ${ }^{157}$ "... a chefia é uma categoria que já entrou em acelerado processo de extinção". Possivelmente seriam estes os postos de trabalho que estão sendo sacrificados.

\subsection{Análise por Regiões}

Ao se iniciar esta pesquisa, pensou-se na possibilidade de realizar um estudo regional nas empresas da amostra. Para tanto, essas empresas seriam agrupadas de acordo

\footnotetext{
${ }_{157}^{156}$ op. cit. p. 20

${ }^{157}$ op. cit. p. 20
} 
com a região geográfica a qual pertencessem. Na seqüência seria feita uma análise conjunta entre os valores distribuídos a e por empregados nas diversas regiões do país e a distribuição de renda e média salarial regionais publicadas pelo IBGE, e alvo desse trabalho no item 2.4.3 - Distribuição de renda no Brasil.

Encontrou-se, entretanto, o seguinte obstáculo: algumas empresas participantes da amostra, dentre elas Petrobrás e Souza Cruz, apesar de apresentarem sede em um Estado da Federação (nos casos citados o Rio de Janeiro), se encontram espalhadas por diversos outros Estados e regiões do país.

A DVA apresentada por estas empresas para a elaboração da edição anual de MM, e constante do cadastro da FIPECAFI, é única e centralizada pela sede.

Portanto, ao se estabelecer o valor adicionado criado e distribuído aos diversos agentes econômicos pelas empresas nas diversas regiões do país, estaria trabalhandose com informação inexata. Apesar dos dados referentes a valor adicionado estarem sendo computados para um Estado ou região, poderiam ter sido gerados em outros locais.

Dessa forma, e por este motivo, os dados existentes levam a conclusão errada de que a riqueza criada pelo Estado do Rio de Janeiro é a maior, ultrapassando São Paulo, o Estado mais rico da Federação. Em 1996, o RJ criou 20,24 bilhões de dólares, contra 13,04 bilhões criados por SP; em 1997, 21,85 bilhões do RJ contra 14,42 bilhões de SP; em 1998, 22,65 bilhões no RJ contra 12,97 bilhões em SP; em 1999, 26,48 bilhões no RJ contra 14,5 bilhões em SP; e em 2000, 31,15 bilhões no RJ contra 11,67 bilhões em SP.

Pelo motivo exposto, não se procedeu à análise dos dados agrupados por regiões, análise esta que seria bastante proveitosa, mas que só poderá ser realizada se as empresas apresentarem suas DVAs por regiões, onde os valores adicionados tivessem sido gerados e distribuídos. 


\subsection{Testes das Hipóteses}

No Capítulo 1, item 1.3 - Hipóteses, foram estabelecidas duas hipóteses para orientação desta pesquisa:

$\mathrm{H}_{1^{-}}$) As empresas que geram maior riqueza, tomando como base os informações constantes na Demonstração do Valor Adicionado, são as que mais a distribuem aos seus funcionários.

$\mathrm{H}_{2^{-}}$) Um incremento provocado na riqueza gerada pelas empresas resulta num aumento na distribuição dessa riqueza aos funcionários, considerando-se as informações da Demonstração do Valor Adicionado.

Volta-se a afirmar que, a aceitação ou negação das hipóteses estabelecidas, servirá apenas para um estudo descritivo e exploratório, não servindo, as constatações encontradas na amostra, para realizar inferências relativas à população, principalmente pelo fato de tratar-se de amostra não-probabilística.

Para teste da primeira hipótese, elaborou-se uma planilha anual (Tabelas de 23 a 26 do Apêndice A), elencando todas as empresas da amostra por ordem de valor adicionado criado, e seu percentual de participação no valor adicionado do total da amostra, partindo-se da empresa que gerou maior valor.

Em seguida, criou-se nova planilha (Tabelas de 27 a 30 do Apêndice A), com todas as empresas da amostra por ordem de valor adicionado distribuído por empregado, partindo-se da empresa que distribuiu maior valor.

Comparou-se, aí, as duas planilhas, ano a ano, partindo-se do ano de 1997, pois, como já foi destacado, o valor adicionado por empregado foi obtido pela divisão do valor distribuído a pessoal e encargos, pelo número médio de empregados. Para obtenção do número médio de empregados, toma-se por base o número de empregados existentes no início e no final do período, entendendo-se por início do 
período o registro existente no último dia do período anterior. Portanto, não há dados sobre a média de empregados para o ano de 1996.

Optou-se por utilizar o valor adicionado distribuído por empregado, por entender-se que, escolhendo fazer a comparação entre a riqueza criada pelas empresas em dólares e o valor em dólares distribuído para pessoal e encargos, haveria o risco de se fazer uma comparação errônea, pois existem empresas que distribuem maior valor para pessoal e encargos porque contam com um número maior de empregados.

Desta forma, considerou-se como melhor distribuição o maior valor adicionado distribuído para cada um dos funcionários, e não a maior distribuição para o conjunto deles.

No ano de 1997, observou-se que as 5 empresas que geraram maior valor adicionado foram as destacadas no Gráfico 49.

\section{Gráfico 49 - Empresas geradoras de maior valor adicionado em 1997}

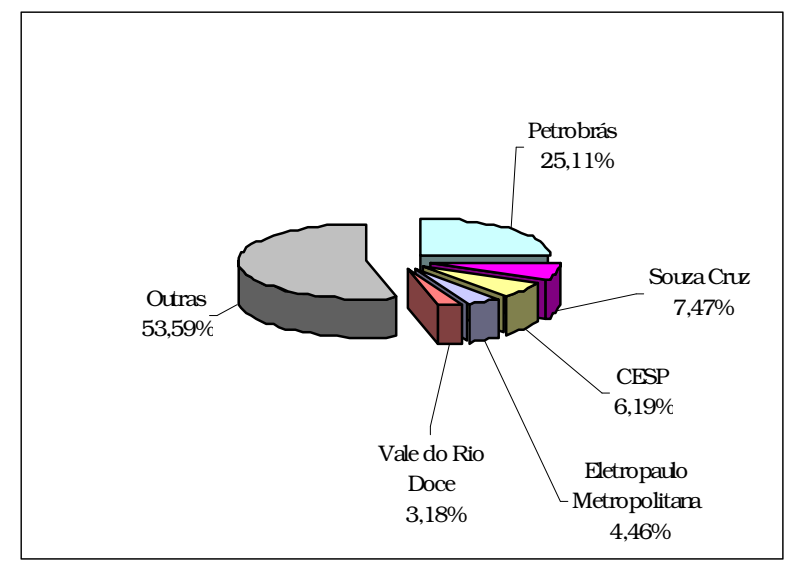

Destacaram-se, portanto, Petrobrás em primeiro lugar, seguida, à distância, pela Souza Cruz, CESP, Eletropaulo Metropolitana e Vale do Rio Doce.

As 5 empresas que distribuíram maior valor adicionado por empregado em 1997 foram as do Gráfico 50. 
Gráfico 50 - Empresas distribuidoras de maior valor adicionado por empregado em 1997

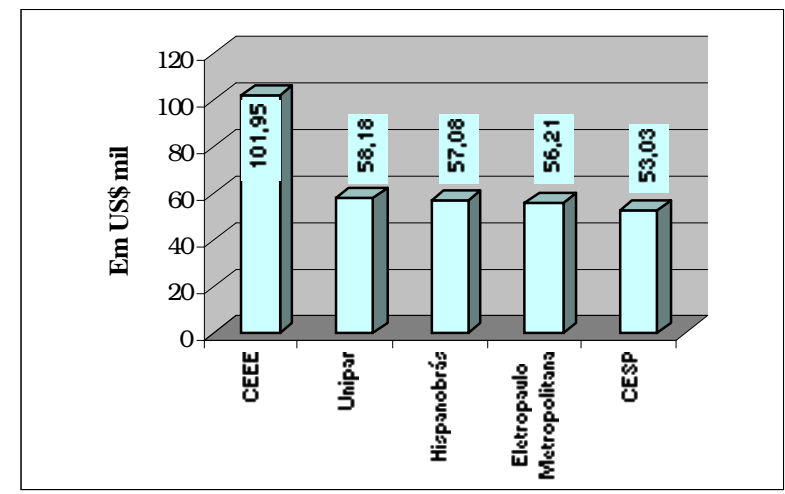

Destaque para CEEE, Unipar, Hispanobrás, Eletropaulo Metropolitana e CESP. Apenas as 2 últimas participaram do rol das 5 maiores geradoras de valor adicionado em 1997.

Em 1998, as 5 maiores criadoras de riqueza estão destacadas no Gráfico 51; e as 5 maiores distribuidoras de valor adicionado por empregado no Gráfico 52.

\section{Gráfico 51 - Empresas geradoras de maior valor adicionado em 1998}

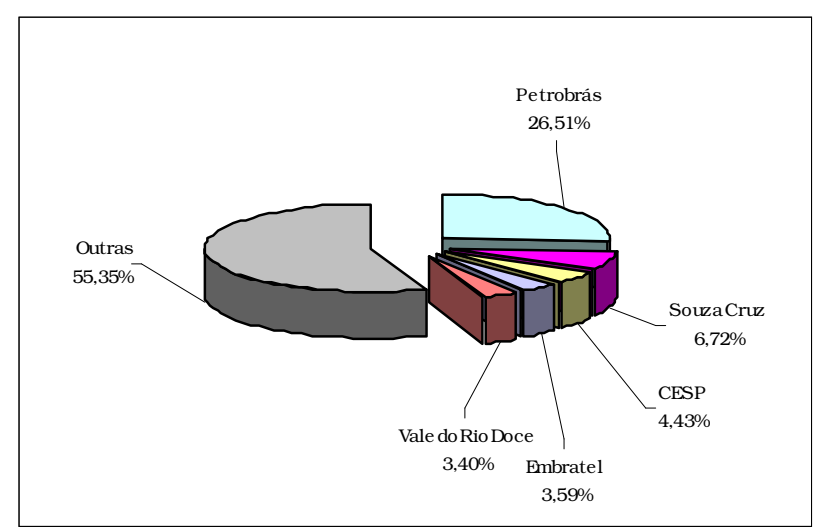

Destaque do primeiro ao quinto lugares para Petrobrás, Souza Cruz, CESP, Embratel e Vale do Rio Doce, respectivamente. 
Gráfico 52 - Empresas distribuidoras de maior valor adicionado por empregado em 1998

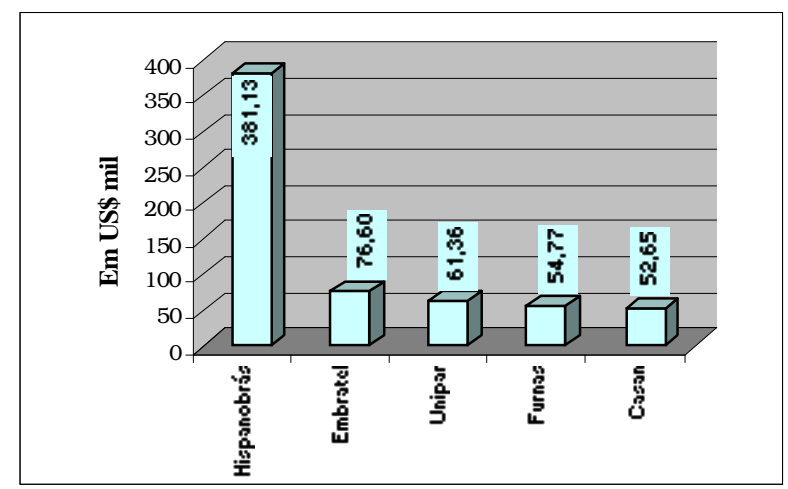

Destaque para Hispanobrás, Embratel, Unipar, Furnas e Casan, observando que há aqui apenas uma das empresas que ocuparam os 5 primeiros lugares quando se avaliou as maiores geradoras de valor adicionado em 1998.

Em 1999, as maiores riquezas foram geradas pelas empresas constantes do Gráfico 53; e as maiores distribuidoras de valor adicionado por empregado foram as do Gráfico 54.

\section{Gráfico 53 - Empresas geradoras de maior valor adicionado em 1999}

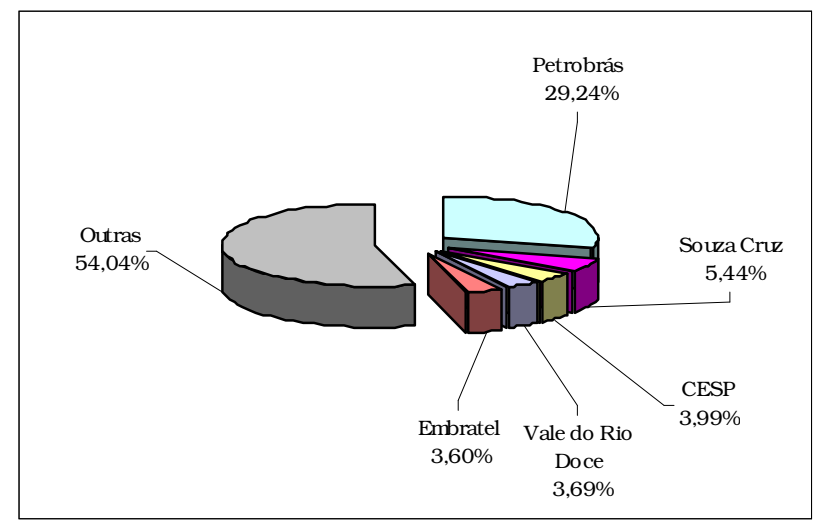

Destaque novamente para Petrobrás, Souza Cruz, CESP, Vale do Rio Doce e Embratel. 
Gráfico 54 - Empresas distribuidoras de maior valor adicionado por empregado em 1999

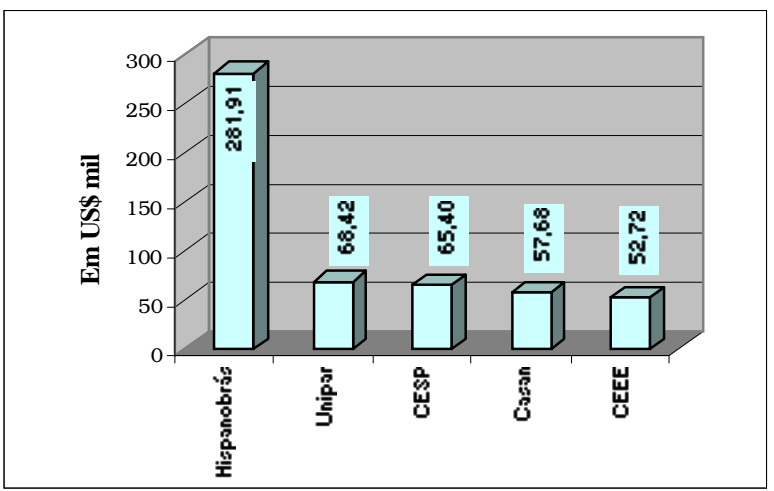

Destaque para Hispanobrás, Unipar, CESP, Casan e CEEE. Apenas a CESP consta, em 1999, como uma das maiores geradoras de valor adicionado.

Para 2000, Petrobrás, Souza Cruz, Embratel, CSN e Eletropaulo Metropolitana foram as maiores criadoras de riqueza conforme Gráfico 55; e Hispanobrás, Unipar, CEEE, Eletronorte e Ipiranga, como maiores distribuidoras de valor adicionado por empregado conforme Gráfico 56. Observa-se que não há na lista de maiores distribuidores de valor adicionado por empregado, nenhuma das empresas consideradas como maiores criadoras de riqueza em 2000.

\section{Gráfico 55 - Empresas geradoras de maior valor adicionado em 2000}

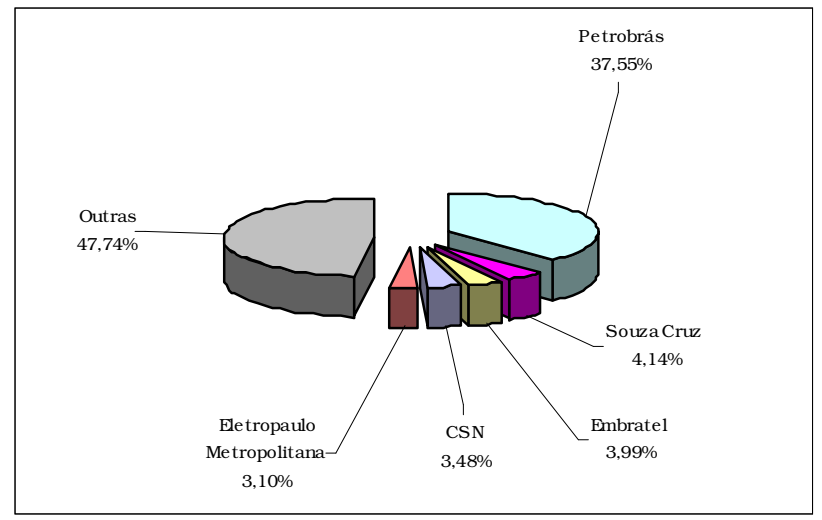




\section{Gráfico 56 - Empresas distribuidoras de maior valor adicionado por empregado em 2000}

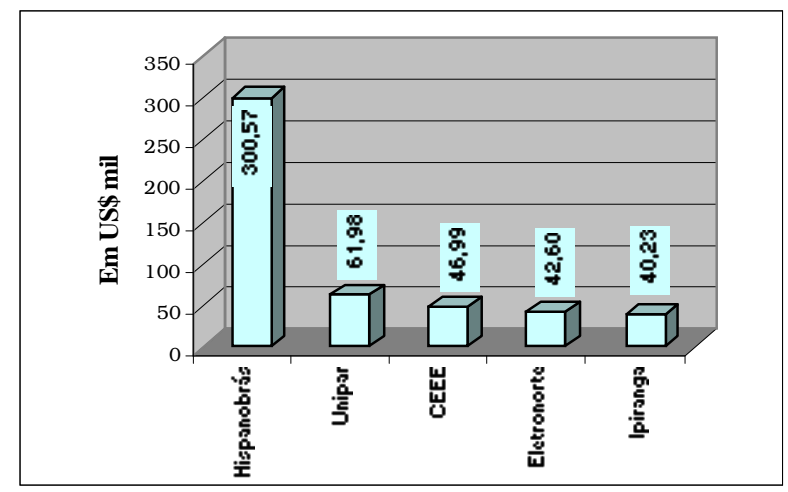

De uma forma geral, durante o período analisado, percebe-se a presença da Petrobrás e Souza Cruz ocupando sempre as 2 primeiras colocações, dentre aquelas empresas da amostra, que mais criaram riqueza. Entre as empresas responsáveis por maior distribuição de valor adicionado por empregado, a presença da Unipar e Hispanobrás é frequente.

Após análises e observações efetuadas, concluiu-se pela não aceitação da primeira hipótese, posto que a mesma não pode ser comprovada. Percebeu-se, durante o período analisado, que, geralmente, na lista de empresas consideradas como maiores criadoras de riqueza em um ano, não consta ou constam poucas empresas que participam do rol daquelas que mais distribuem valor adicionado por empregado. Constatando-se, assim, que apesar de existir relação entre geração de riqueza e distribuição de valor adicionado a empregados, ela não é diretamente proporcional.

Para o teste da segunda hipótese, procedeu-se à avaliação da riqueza gerada pelas empresas participantes da amostra ao longo dos períodos analisados, e à distribuição do valor adicionado (VA), por funcionário.

Para execução da análise, agrupou-se as empresas por ramos de atividade e por setor. 
Calculou-se inicialmente a evolução da geração de valor adicionado de 1997 a 2000, por ramo de atividade e setor, pelos percentuais de acréscimo ou de decréscimo, conforme Tabelas 3 e 6 do Apêndice A. A seguir, elaborou-se o mesmo cálculo, tomando-se por base o valor adicionado por empregado ao longo dos anos (Tabelas 4 e 17 do Apêndice A).

Decidiu-se pela utilização do valor adicionado por empregado por entender-se que, ao usar o valor total distribuído a pessoal e encargos, este poderia ser influenciado pelo aumento ou diminuição no número de empregados, provocando distorções; com o uso do valor distribuído a cada funcionário percebe-se, realmente, se houve incremento ou não na distribuição.

Finalmente, usou-se o recurso estatístico denominado coeficiente de correlação (r), para confirmar a existência ou não de correlação entre as duas variáveis (Quadros 16 e 17 do Apêndice A).

Conforme Lapponi ${ }^{158}$, o valor do coeficiente de correlação (r) pode ser nulo, positivo ou negativo. Quando duas séries de observações apresentam $r=+1$, essas séries estão perfeitamente correlacionadas em sentido positivo, mostrando que os incrementos dos valores das duas variáveis são proporcionais e na mesma direção. Quando as duas séries apresentam $r=-1$, essas séries estão perfeitamente correlacionadas em sentido negativo, significando que os incrementos dos valores nas duas variáveis são proporcionais, mas em direções opostas. Se $r=0$, não existe nenhuma relação entre as duas variáveis. Quanto mais próximo $\mathrm{r}$ estiver de 1, mais forte será a correlação. Quanto mais próximo r estiver de 0 , mais fraca ela será.

Ao se observar a evolução da riqueza e do valor adicionado por empregado nos ramos de atividade, constatou-se as variações constantes da Tabela 37.

\footnotetext{
${ }^{158}$ LAPPONI, Juan Carlos. Estatística usando Excel 5 e 7. São Paulo: Lapponi Treinamento e editora, 1997. p. $144-147$
} 
Tabela 37 - Variações na evolução da riqueza e do valor adicionado por empregado por ramos de atividades

\begin{tabular}{l|c|c|c|c}
\hline \multirow{2}{*}{ Variação/Período } & \multicolumn{4}{c}{ Comércio } \\
\cline { 2 - 5 } & $\mathbf{9 7 / 9 8}$ & $\mathbf{9 8 / 9 9}$ & $\mathbf{9 9 / 0 0}$ & $\mathbf{9 7 / 0 0}$ \\
\hline Da riqueza & $12,55 \%$ & $-4,80 \%$ & $-10,46 \%$ & $-4,07 \%$ \\
\hline Do VA por empregado & $-4,53 \%$ & $-10,42 \%$ & $-8,68 \%$ & $-21,92 \%$ \\
\hline & \multicolumn{5}{|c}{ Indús tria } \\
\hline & $\mathbf{9 7 / 9 8}$ & $\mathbf{9 8 / 9 9}$ & $\mathbf{9 9 / 0 0}$ & $\mathbf{9 7 / 0 0}$ \\
\hline Da riqueza & $1,49 \%$ & $22,95 \%$ & $10,87 \%$ & $38,35 \%$ \\
\hline Do VA por empregado & $-0,59 \%$ & $-9,04 \%$ & $-9,70 \%$ & $-18,33 \%$ \\
\hline & \multicolumn{5}{|c}{ Se rviços } \\
\hline & $\mathbf{9 7 / 9 8}$ & $\mathbf{9 8 / 9 9}$ & $\mathbf{9 9 / 0 0}$ & $\mathbf{9 7 / 0 0}$ \\
\hline Da riqueza & $-8,92 \%$ & $2,98 \%$ & $-11,58 \%$ & $-17,06 \%$ \\
\hline Do VA por empregado & $-8,11 \%$ & $-18,28 \%$ & $-9,41 \%$ & $-31,98 \%$ \\
\hline
\end{tabular}

Em relação ao comércio, constata-se que o mesmo apresentou crescimento de riqueza apenas de 1997 para 1998, da ordem de 12,55\%, enquanto o valor adicionado distribuído por empregado nesse mesmo período caiu 4,53\%. De 1998 para 1999, ambos os índices apresentaram decréscimo, mas, enquanto a riqueza diminuiu $4,80 \%$, a queda no valor adicionado por empregado foi de $10,42 \%$. No último período analisado, os dois índices apresentaram queda, mas também de ordens diferentes: $10,46 \%$ na riqueza e $8,68 \%$ no valor adicionado por empregado. A variação da riqueza, tomado o período de 1997 a 2000, foi decrescente em 4,07\%, e a variação do valor adicionado por empregado, no mesmo período, foi de 21,92\%, também decrescente. $\mathrm{O}$ coeficiente de correlação calculado para esse ramo de atividade foi de $r=0,40438$, mostrando uma correlação fraca, apesar de positiva.

$\mathrm{Na}$ indústria, houve crescimento de riqueza durante todo o período, variando de 1,49\% de 1997 para 1998, 22,95\% de 1998 para 1999, e 10,87\% de 1999 para 2000, enquanto o valor adicionado por empregado apenas decresceu e em percentuais evolutivos. Analisado o período de 1997 a 2000, a riqueza gerada apresentou aumento de $38,35 \%$, enquanto o valor adicionado distribuído por empregado caiu $18,33 \%$. Uma outra evidência mostrando a desigualdade na evolução das variáveis utilizadas foi o coeficiente de correlação, que apresentou o valor de $r=-0,99246$ traduzindo uma forte correlação, entretanto, em sentido negativo, demonstrando crescimento na criação de riqueza e decréscimo no valor adicionado por empregado. 
Nos serviços o valor de $\mathrm{r}=0,7968$ mostra uma correlação positiva mais significativa, levando à dedução que as variáveis guardaram alguma relação. Pelo menos em alguns períodos foi o que ocorreu. De 1997 para 1998, a queda no valor adicionado por empregado, 8,11\%, acompanhou a queda na riqueza, 8,92\%. De 1999 para 2000, a proporcionalidade também se manteve aproximada: $11,58 \%$ de diminuição na riqueza e 9,41\% no valor adicionado por empregado. Entretanto, no período de 1998 para 1999, as variáveis apresentaram comportamento totalmente distinto, com aumento de 2,98\% na geração de riquezas contra uma queda substancial de 18,28\% no valor adicionado distribuído por empregado. Tomado o período 1997 a 2000, observa-se decréscimo tanto na riqueza quanto no valor adicionado por empregado. Entretanto, enquanto no primeiro esse foi de $17,06 \%$, no segundo atingiu $31,98 \%$.

Nos 25 setores analisados, as variações ocorridas na riqueza e no valor adicionado distribuído por empregado estão expressas na Tabela 38.

Observa-se que, no período de 1997 para 1998, 10 dos 25 setores analisados apresentaram comportamento distinto nas variáveis, crescimento de uma delas com decréscimo da outra. De 1998 para 1999, esse número passou a ser de 9 entre os 25 setores, aumentando para 15 no período de 1999 para 2000.

O coeficiente de correlação dos diversos setores está explicitado no Gráfico 57. Pela sua observação, nota-se que 12 dos 25 setores analisados apresentaram coeficiente de correlação negativo, significando que houve variação positiva (crescimento) em uma das variáveis e variação negativa (decréscimo) na outra. Os setores que apresentaram um alto grau de correlação positiva foram os de serviços públicos, com $r=0,91226 \mathrm{e}$ serviços de transporte, com $r=0,93202$. 
Tabela 38 - Variações na evolução da riqueza e do valor adicionado por empregado por setores

\begin{tabular}{|c|c|c|c|c|}
\hline \multirow{2}{*}{ Setores } & \multirow{2}{*}{ Variação } & \multicolumn{3}{|c|}{ Períodos } \\
\hline & & 97/98 & 98/99 & 99/00 \\
\hline \multirow{2}{*}{ Alimentos } & Da riqueza & crescente & crescente & decrescente \\
\hline & Do VA por empregado & decrescente & decrescente & decrescente \\
\hline \multirow{2}{*}{ Atacado e Comércio Exterior } & Da riqueza & crescente & decrescente & decrescente \\
\hline & Do VA por empregado & decrescente & decrescente & decrescente \\
\hline \multirow{2}{*}{ Automotivo } & Da riqueza & crescente & decrescente & crescente \\
\hline & Do VA por empregado & crescente & decrescente & decrescente \\
\hline \multirow{2}{*}{ Bebidas } & Da riqueza & crescente & crescente & crescente \\
\hline & Do VA por empregado & decrescente & crescente & decrescente \\
\hline \multirow{2}{*}{ Comércio Varejista } & Da riqueza & crescente & decrescente & decrescente \\
\hline & Do VA por empregado & decrescente & decrescente & decrescente \\
\hline \multirow{2}{*}{ Comunicações } & Da riqueza & crescente & decrescente & decrescente \\
\hline & Do VA por empregado & crescente & decrescente & decrescente \\
\hline \multirow{2}{*}{ Confecções e Têxteis } & Da riqueza & crescente & crescente & decrescente \\
\hline & Do VA por empregado & decrescente & crescente & decrescente \\
\hline \multirow{2}{*}{ Construção } & Da riqueza & crescente & decrescente & decrescente \\
\hline & Do VA por empregado & crescente & decrescente & crescente \\
\hline \multirow{2}{*}{ Diversos } & Da riqueza & crescente & crescente & decrescente \\
\hline & Do VA por empregado & crescente & decrescente & crescente \\
\hline \multirow{2}{*}{ Eletroeletrônico } & Da riqueza & decrescente & decrescente & crescente \\
\hline & Do VA por empregado & crescente & crescente & decrescente \\
\hline \multirow{2}{*}{ Farmacêutico } & Da riqueza & crescente & decrescente & decrescente \\
\hline & Do VA por empregado & crescente & decrescente & crescente \\
\hline \multirow{2}{*}{ Fumo } & Da riqueza & decrescente & decrescente & decrescente \\
\hline & Do VA por empregado & decrescente & decrescente & crescente \\
\hline \multirow{2}{*}{ Higiene, Limpeza e Cosméticos } & Da riqueza & crescente & crescente & decrescente \\
\hline & Do VA por empregado & crescente & decrescente & decrescente \\
\hline \multirow{2}{*}{ Material de Construção } & Da riqueza & crescente & crescente & crescente \\
\hline & Do VA por empregado & decrescente & crescente & decrescente \\
\hline \multirow{2}{*}{ Mecânica } & Da riqueza & crescente & crescente & decrescente \\
\hline & Do VA por empregado & decrescente & crescente & crescente \\
\hline \multirow{2}{*}{ Mineração } & Da riqueza & crescente & crescente & decrescente \\
\hline & Do VA por empregado & decrescente & decrescente & decrescente \\
\hline \multirow{2}{*}{ Papel e Celulose } & Da riqueza & decrescente & crescente & crescente \\
\hline & Do VA por empregado & crescente & crescente & decrescente \\
\hline \multirow{2}{*}{ Plásticos e Borrachas } & Da riqueza & crescente & decrescente & crescente \\
\hline & Do VA por empregado & crescente & decrescente & crescente \\
\hline Ouímica e Petroquímica & Da riqueza & crescente & crescente & crescente \\
\hline & Do VA por empregado & crescente & decrescente & decrescente \\
\hline Servico de Transnorte & Da riqueza & crescente & crescente & decrescente \\
\hline & Do VA por empregado & crescente & crescente & decrescente \\
\hline Servicos Diversos & Da riqueza & crescente & decrescente & crescente \\
\hline SCIVIÇOS DIVETSOS & Do VA por empregado & crescente & decrescente & decrescente \\
\hline Servicos Públicos & Da riqueza & decrescente & crescente & decrescente \\
\hline 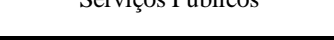 & Do VA por empregado & decrescente & decrescente & decrescente \\
\hline Sideruroia e Metaluroia & Da riqueza & decrescente & crescente & crescente \\
\hline 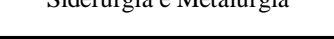 & Do VA por empregado & decrescente & decrescente & decrescente \\
\hline Tecnologia e Comnutac̃̃o & Da riqueza & crescente & decrescente & crescente \\
\hline 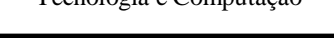 & Do VA por empregado & crescente & decrescente & decrescente \\
\hline Telecomuniccacõ & Da riqueza & crescente & crescente & crescente \\
\hline 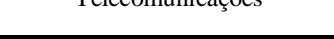 & Do VA por empregado & crescente & decrescente & decrescente \\
\hline
\end{tabular}




\section{Gráfico 57 - Coeficientes de correlação dos diversos setores}

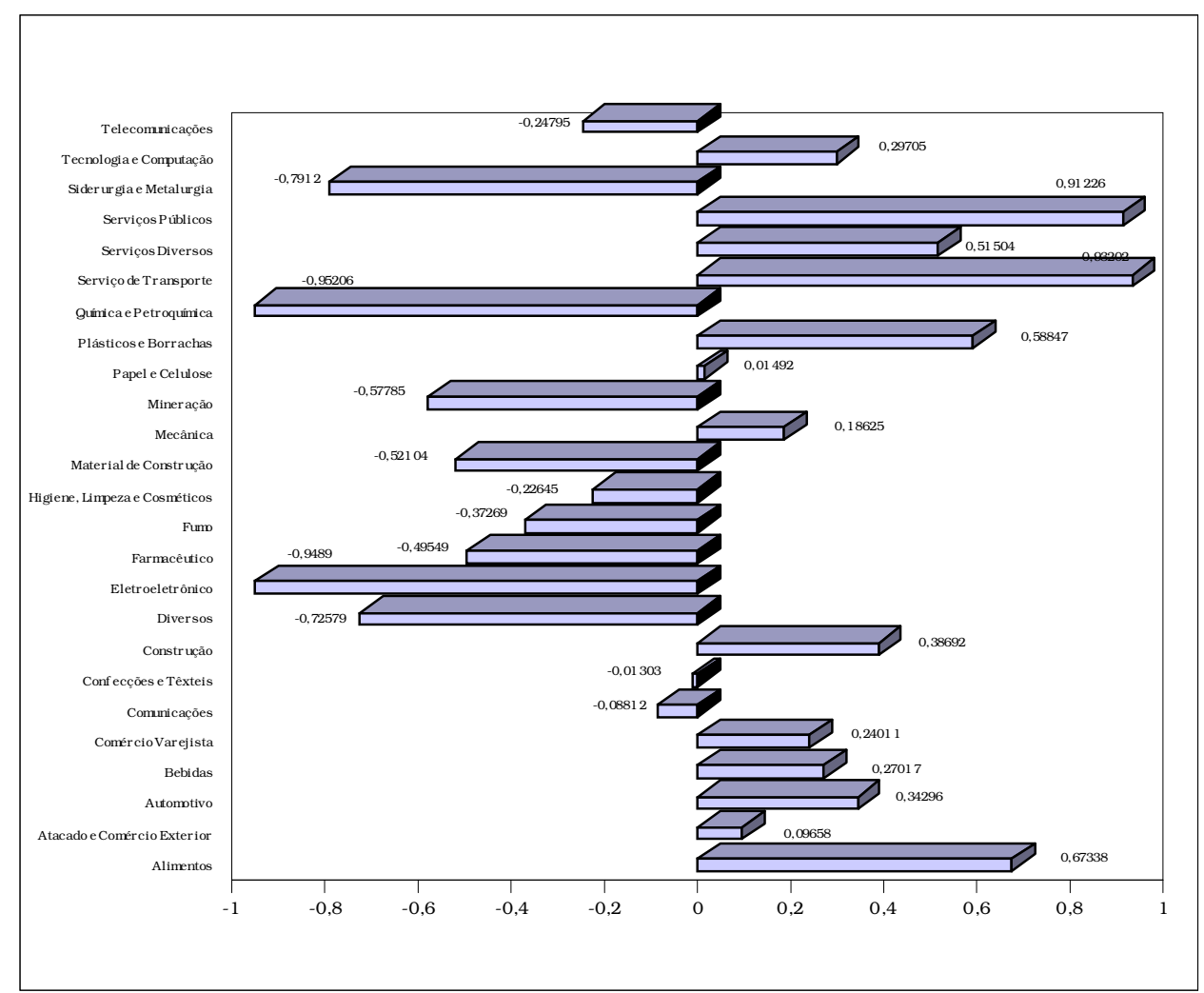

Após análises, observações e cálculos estatísticos, concluiu-se pela não aceitação da segunda hipótese formulada, visto que em alguns setores como eletroeletrônicos, química e petroquímica, siderurgia e metalurgia e diversos, observou-se exatamente o contrário, ou seja, um incremento em uma das variáveis, com um decréscimo na outra. De uma forma geral, a riqueza gerada pelas empresas da amostra apresentou acréscimo ao longo do período analisado, enquanto o valor adicionado por empregado teve comportamento oposto, decresceu. Nos ramos de atividade analisados o comércio e serviços apresentaram queda em ambas as variáveis, e a indústria apresentou aumento de riqueza com queda no valor adicionado distribuído por empregado. 


\section{CAPÍTULO 6 - CONCLUSÕES}

Como foi divulgado ao longo desse trabalho, o Balanço Social com suas vertentes - a de recursos humanos, a ambiental, a das relações com a sociedade e a do valor adicionado - é o instrumental que a contabilidade colocou à disposição de seus usuários, atendendo às exigências da sociedade por informações sócio-econômicas que demonstrassem o grau de responsabilidade e envolvimento social das empresas.

Observou-se que, como o Balanço Social ainda não é obrigatório no Brasil, é apresentado voluntariamente por algumas empresas, umas com o intuito de apenas fornecer maiores informações aos seus usuários, outras com objetivos de marketing. Pela própria estrutura do modelo de Balanço Social elaborado pelo IBASE, percebeu-se que ele conta com informações sobre o quanto a empresa investiu, seja em capacitação e desenvolvimento profissional, segurança e medicina do trabalho, meio ambiente e outros, mas, sem se ater a questões sobre a mensuração do quanto isto custou à sociedade. Mas isso não é mérito apenas do modelo brasileiro, já que nos modelos de todos os outros países que se teve a oportunidade de conhecer, esse fato também ocorre.

Com relação à DVA, foco específico deste estudo, percebeu-se que, apesar do número considerável de empresas que a envia ao cadastro da FIPECAFI, são poucas as que a divulgam para o conhecimento de toda a sociedade. Provavelmente, faz bem às empresas e aos seus produtos, constarem da lista de MM. Portanto, o motivo não é outro senão a vinculação da imagem da empresa a questões sociais e ambientais.

Apesar do esforço que vem sendo feito por entidades de classe, agremiações acadêmicas, e outros, muito ainda há que se fazer. 
A DVA possibilita o conhecimento do quanto cada empresa criou de riqueza e como a distribuiu aos agentes econômicos que ajudaram a criá-la. Além de atender a um maior número de usuários, amplia o universo atingido pela contabilidade e tem a grande vantagem de ser facilmente lida e interpretada. Como mostrado, serve como um excelente instrumento de análise, principalmente quando a questão é comparativa. Por meio da DVA, consegue-se perceber como a riqueza criada foi distribuída aos agentes e quais deles ficam com a maior parte dela, levando, inclusive, a inferências sobre se estes são os agentes que mais colaboraram na sua criação. É o caso do governo, que vem ficando com a maior parte da riqueza gerada.

Entende-se que uma das formas de distribuição de renda existentes seja a cobrança de tributos pelo governo e seu posterior repasse. Arrecada-se mais daquela parcela da população que possui maior poder contributivo, e distribui-se esse recurso àquela parcela mais carente da população, por meio de investimentos em saúde, educação, e outros. Portanto, o fato do governo ficar com a maior parte da riqueza gerada, deveria ser reconhecido como benéfico. Isso se não se constatasse que a pobreza e miséria são cada vez maiores no Brasil. Ressalte-se que a essência da cobrança de tributos é bastante distributiva (cobrar dos que têm mais e entregar aos que têm menos), mas infelizmente não é o que se pratica.

Quanto à distribuição de renda por meio de remuneração paga aos empregados, concluiu-se, neste estudo, que não existe relação entre a riqueza gerada pelas empresas e a sua distribuição aos funcionários. As entidades que geram maior volume de riqueza não são, geralmente, as que a distribuem em maior quantidade aos empregados. Observou-se que, em 1997, as 5 maiores empresas geradoras de valor adicionado foram, respectivamente, Petrobrás, Souza Cruz, CESP, Eletropaulo Metropolitana e Vale do Rio Doce, enquanto as que mais distribuíram valor adicionado por empregado foram CEEE, Unipar, Hispanobrás, Eletropaulo Metropolitana e CESP. Em 1998, constaram como maiores criadoras de riqueza Petrobrás, Souza Cruz, CESP, Embratel e Vale do Rio Doce, e como maiores pagadoras Hispanobrás, Embratel, Unipar, Furnas e Casan. Em 1999, Petrobrás, Souza Cruz, CESP, Vale do Rio Doce e Embratel geraram maior riqueza, e, 
Hispanobrás, Unipar, CESP, Casan e CEEE, distribuíram maior valor adicionado por empregado. Finalmente em 2000, a lista de maiores geradoras de valor adicionado formada por Petrobrás, Souza Cruz, Embratel, CSN e Eletropaulo Metropolitana é totalmente distinta daquela formada por maiores distribuidoras de valor adicionado por empregado, onde constam Hispanobrás, Unipar, CEEE, Eletronorte e Ipiranga.

E, ainda, o fato da empresa aumentar sua geração de riqueza, não determina que o repasse aos empregados acompanhe esse acréscimo. Do ano de 1997 para o de 1998, por exemplo, o comércio apresentou um acréscimo na riqueza gerada de $12,55 \%$, e uma queda no valor adicionado distribuído por empregado de 4,53\%. Na indústria, de 1998 para 1999, houve aumento na riqueza de 22,95\%, e diminuição no valor adicionado por empregado de $9,04 \%$. Nesse mesmo período, serviços criou uma riqueza $2,98 \%$ maior, e distribuiu um valor adicionado por empregado $18,28 \%$ menor. Em alguns setores, como química e petroquímica, enquanto a riqueza se mostrou ascendente ao longo de todo o período analisado, o valor adicionado distribuído por empregado se manteve decrescente na maior parte dele. Ou, o setor de eletroeletrônicos, onde a riqueza criada apresentou queda na maior parte do período, enquanto o valor adicionado por empregado aumentava.

Outra constatação foi quanto à queda no número de postos de trabalho. O que se percebeu foi que o país, prestes a entrar no terceiro milênio, não conseguiu gerar emprego para a grande massa de pessoas que precisam trabalhar. Um efeito da globalização é o aumento da concorrência. Para tanto, a empresa precisa estar preparada. Não é dada a ela a oportunidade de escolher entre inovar ou não. A empresa que não inova, desaparece do mercado, fecha as portas e seus trabalhadores perdem o emprego. Na empresa que inova, aplica em tecnologia, robótica, que normalmente é mais barata que seres humanos, os seus trabalhadores também perdem os empregos. Assim, forma-se um excedente natural de força de trabalho que não consegue ser absorvido totalmente, o que foi agravado pela entrada maciça das mulheres no mercado de trabalho no pós guerra. 
Por meio da DVA, consegue-se avaliar se estes fatos são setoriais, se são recorrentes, ou ainda, se vêm apresentando acréscimo ou decréscimo. E foi o que se constatou nesta pesquisa. Dos 25 setores analisados, observou-se a diminuição de postos de trabalho em 18 deles, no período. Em alguns - como fumo, telecomunicações, eletroeletrônicos, e higiene, limpeza e cosméticos - a queda foi superior a 20\%, o que corresponde a 10.163 vagas a menos. Apenas o setor de serviços públicos foi responsável pelo desaparecimento de mais de 32.000 postos - fruto talvez, da privatização e da queda no nível geral de salários. E, só 7 deles criaram novas vagas. A diminuição na distribuição de valor adicionado por empregado, também foi analisada setorialmente, constatando-se que apenas 8 setores aumentaram esse valor - papel e celulose, farmacêutico,construção, fumo, diversos, serviços de transporte, serviços diversos, e comunicações. Interessante, é que 14 setores aumentaram sua geração de riqueza no período. Entretanto, o que se constatou é que esse crescimento de riqueza foi canalizado para outros agentes e não para os empregados.

Resta, apenas, que essa demonstração se adapte às necessidades informativas dos usuários, sendo elaborada, por exemplo, de forma descentralizada, por estados e regiões onde a empresa atua. Dessa forma, as informações prestadas serão de mais valia, podendo ser analisadas em conjunto com aquelas divulgadas pelo IBGE sobre a renda da população, por região. Pois, conforme se salientou nesse trabalho, apesar de existir a informação referente ao local de sede das empresas, não se pode considerá-la como a geradora de toda a riqueza criada, visto que as empresas possuem unidades em outros Estados da Federação. E, ainda, deveriam vir acrescidas de dados sobre o número de empregados existentes na empresa no início e final do período, a exemplo do que é solicitado pela FIPECAFI, para que se pudesse proceder ao acompanhamento dos postos de trabalho existentes.

Portanto, conclui-se que a DVA é mais que uma nova demonstração contábil que faz parte do balanço social, tendo força própria, pois contém informações que sozinhas são conclusivas e bastante úteis, não precisando estar, necessariamente atrelada a ele. E, torna-se possível afirmar que os indicadores retirados desse demonstrativo constituem-se num excelente avaliador da distribuição da riqueza, à disposição da 
contabilidade, no entanto sem nenhuma pretensão em substituir, ou até mesmo rivalizar, outros indicadores de riqueza já existentes.

Mas, para atingir ao seu grande potencial é necessário que seja bem elaborada e bastante divulgada. Só assim ela poderá atender, de forma satisfatória, e principalmente servir como guia a novos usuários, ou a antigos, que não contavam com informações específicas - como é o caso dos empregados e das comunidades onde as entidades estão inseridas - podendo ainda ser utilizada pelos sindicatos das categorias, como informação quando das negociações salariais, fazendo com que o conjunto de trabalhadores também sejam beneficiados pelos aumentos de produtividade e de riqueza na empresa, nos quais eles se constituem em peças chave, e, trazendo para a sociedade a oportunidade de cobrar o que lhe é devido.

A elaboração da DVA, e, principalmente, sua divulgação, podem ser, ainda, a oportunidade que a contabilidade tem para mostrar seu alcance e utilidade para aqueles que não a vêm assim. Serviria, assim, como instrumento de marketing para a própria ciência que a criou.

Finalmente, cabe aqui a sugestão para novos estudos, tanto pesquisas exploratórias específicas em um único setor, ramo de atividade ou empresa, quanto a correlação de informações constantes da DVA e do Balanço Social. Ressalte-se o fato de existir informações de naturezas coincidentes nos referidos demonstrativos; todavia, os dados apresentados na DVA são consistentes com as demais demonstrações contábeis, as quais estão sujeitas a auditoria, o que lhes dá maior grau de confiabilidade - podendo, inclusive, ser facilmente reconciliada com os valores apresentados na Demonstração de Resultado do Exercício, por exemplo. As informações do Balanço Social ainda não se apresentam uniformes, de maneira que seu estudo exigiria a formação de um banco de dados, a partir de uma metodologia passível de verificação pelo usuário externo e, idealmente, desenvolvido junto às empresas, a partir de um modelo científico preparado pelo pesquisador. 


\section{BIBLIOGRAFIA}

ALVES, Ieda Maria (coord.). Glossário de termos neológicos da economia. São Paulo: Humanitas/FFLCH/USP, 1998.

BANCO DE BILBAO. Balance social del grupo bancário 1979/81. Bilbao: 1992.

BANCO MUNDIAL. Relatório sobre o desenvolvimento mundial 2000/2001. Disponível em http://www.worldbank.org/poverty/portuguese/wdr/tab05.pdf. Acesso em: 11/03/02.

BARROS, Ricardo Paes. HENRIQUES, Ricardo. MENDONÇA, Rosane. A estabilidade inaceitável: desigualdade e pobreza no Brasil. Rio de Janeiro: IPEA, jun. 2001 p. 12. (Texto para discussão $\mathrm{n}^{\circ}$ 800). Disponível em: http://ipea.gov.br/pub/td 2001/td0800.pdf. Acesso em: 11/03/02.

BELKAOUI, Ahmed. The new environment in international accounting. Quorum Books, 1998.

BETING, Joelmir. Balanço social. O Estado de São Paulo. São Paulo: 17 de ago. 1997.

BRASIL. Constituição (1988). Constituição da República Federativa do Brasil. Brasília, DF: Senado, 1988.

Decreto $n^{0} .76 .900$ de 23 de dezembro de 1975. Institui a Relação Anual de Informações Sociais e dá outras providências.

ações.

Lei ${ }^{0}$. 6.404 de 15 de dezembro de 1976. Dispõe sobre as sociedades por

Medida Provisória nº 1.818 de 25 de março de 1999. Estabelece normas para registro do resultado líquido negativo decorrente do ajuste dos valores em reais de obrigações e créditos, e dá outras providências.

Portaria $\mathrm{n}^{0} 699$ de 12 de dezembro de 2001. Dispõe sobre o preenchimento entrega e fiscalização da RAIS ano-base 2001.

Projeto de Lei n $^{0} 0032$ de 03 de fevereiro de 1999. Cria o balanço social para as empresas que menciona e dá outras providências.

Projeto de Lei $\mathbf{n}^{0}$. 2.813 de 05 de abril de 2000. Estabelece a obrigatoriedade de publicação das demonstrações financeiras das sociedades por quotas de responsabilidade limitada, alterando o art. 18 do Decreto ${ }^{\circ} 3.708$, de 10 de janeiro de 1919, que regula a constituição de sociedades por quotas de responsabilidade limitada. 
Projeto de Lei $n^{0}$. 3.116 de 14 de maio de 1997. Cria o balanço social para as empresas que menciona e dá outras providências.

Projeto de Lei $\mathbf{n}^{\mathbf{0}}$. 3.741 de 8 de novembro de 2000. Altera e revoga dispositivos da Lei 6.404, de 15 de dezembro de 1976, define e estende às sociedades de grande porte disposições relativas à elaboração e publicação de demonstrações contábeis e dispõe sobre os requisitos de qualificação de entidades de estudo e divulgação de princípios, normas e padrões de contabilidade e auditoria como Organização da Sociedade Civil de Interesse Público.

Projeto de Lei $\mathbf{n}^{\circ}$. 5.483 de 04 de outubro de 2001. Altera o artigo 618 da Consolidação das Leis do Trabalho - CLT.

BRAZ, Adriana. A importância do balanço social. Revista Mercado de Capitais. São Paulo: $\mathrm{n}^{\circ}$. 176, 12-13, jan./fev.1999.

BUSSAB, Wilton O. MORETTIN, Pedro A. Estatística básica. 4. ed. São Paulo: Atual, 1987.

CAPPELLIN, Paola, GIULIANI, Gian Mario. Compromisso social no mundo dos negócios. Boletim do IBASE. Rio de Janeiro: ano 6, nº . 11, 10-11, fev. 1999.

CARDOSO JR., José Celso. Anatomia da distribuição de renda no Brasil: estrutura e evolução nos anos 90. Dissertação de Mestrado - Instituto de Economia da Universidade de Campinas. Campinas: UNICAMP, 1999.

Geração e apropriação de valor adicionado na economia brasileira: um estudo da dinâmica distributiva no período 1990/1996. IPEA, Instituto de Pesquisa Econômica Aplicada. Rio de Janeiro: 2000. (Texto para discussão no 733). Disponível em http://www.ipea.gov.br/pub/td/td 2000/td0733.pdf. Acesso em: 11/03/02.

CARVALHO, Luis Carlos de. Balanço social. Revista Trevisan. São Paulo: ano XIII, $n^{\circ} .143,26-29,2000$.

DEL GROSSI, Mauro Eduardo. SILVA, José Graziano. TAKAGI, Maya. Evolução da pobreza no Brasil, 1995/99. Campinas: UNICAMP, n. 104, nov. 2001 p.2. Disponível em http://www.eco.unicamp.br/publicacoes/textos/dowload/texto104.pdf Acesso em: 11/03/02.

DE LUCA, Márcia Martins Mendes. A contribuiçãa da demonstração do valor adicionado no processo de mensuração do PIB e em algumas análises macroeconômicas. Tese de doutoramento - Faculdade de Economia e Contabilidade da Universidade de São Paulo. São Paulo: FEA/USP, 1996.

Demonstração do valor adicionado. Dissertação de mestrado Faculdade de Economia e Contabilidade da Universidade de São Paulo. São Paulo: FEA/USP, 1991. 
Demonstração do valor adicionado: do cálculo da riqueza criada pela empresa ao valor do PIB. São Paulo: Atlas, 1998.

DUPAS, Gilberto. Economia global e exclusão social: pobreza, emprego, estado e o futuro do capitalismo. 2. ed. São Paulo: Paz e Terra, 2000.

ELISEU quer balanço social sem imposições legais. São Paulo: SIA \& CIA, $n^{\circ} .421$, p. 3, 09 nov. 1998.

ELORRIAGA, Aitiziber Mugarra. Coleccion de casos. España: Universidad de Deusto, 2001.

FERRARI, Alfonso Trujillo. Metodologia da pesquisa científica. São Paulo: McGraw-Hill do Brasil, 1982.

FERREIRA, Aurélio Buarque de Holanda. Novo Aurélio Século XXI: o dicionário da língua portuguesa. 3. ed. Rio de Janeiro: Nova Fronteira, 1999.

FRANÇA. Lei $\mathbf{n}^{\mathbf{0}} \mathbf{7 7 . 7 6 9}$ du 12 juillet 1997. Relative au bilan social de \entreprise.

FREIRE, Fátima de Souza. Balanço social à brasileira. Gazeta Mercantil. São Paulo: 28 dez. 2000, p. A2.

FREIRE, Fátima de Souza, MALO, François Bernard. Memória social e decisões estratégicas. Boletim do IBASE. Rio de Janeiro: ano 6, $\mathrm{n}^{\mathrm{o}}$. 12, 10-11, jun. 1999.

GLAUTIER, M.W.E., UNDERDOW B. Accounting theory and pratice. Great Britain: 3. ed. Pitman, 1986. p. 468.

GOMES, Sônia Maria da Silva. O uso das informações contábeis como instrumento orientador das negociações trabalhistas no Brasil. Dissertação de mestrado - Faculdade de Economia e Contabilidade da Universidade de São Paulo. São Paulo: FEA/USP, 1998.

GONÇALVES, Ernesto Lima (org.) Balanço social na América Latina.Tradução Maria Aparecida Ataliba de L.Gonçalves. Livraria Pioneira Editora. São Paulo: 1980.

GOULART, Josette. CVM quer publicação do balanço social. Gazeta Mercantil. São Paulo: 25 jun. 1999, p. A8.

GUERREIRO, Reinaldo. Modelo conceitual de sistema de informação de gestão econômica: uma contribuição a teoria da comunicação da contabilidade. Tese de doutoramento - Faculdade de Economia e Contabilidade da Universidade de São Paulo. São Paulo: FEA/USP, 1989. 
HALLER, Axel. STOLOWY, Hervé. Valued added in financial accounting, a comparative study of Germany and France - Advances in international accounting. Vol. II. JAI press inc. 1998

HUBERMAN, Leo. História da riqueza do homem. Tradução Waltensir Dutra. 17. ed. Rio de Janeiro: Zahar, 1981.

INSTITUTO BRASILEIRO DE ANÁLISES SOCIAIS E ECONÔMICAS - IBASE. Balanço social anual - 2001. Disponível em http://www.balancosocial.org.br/downbs/bsMODELO2001.doc. Acesso em: 21/03/02.

IBGE. Contas nacionais do Brasil. Disponível em http://www.ibge.gov.br/home/estatistica/economia/contasnacionais/tabela5.shtm.

Acesso em: 18/04/02.

Indicadores sociais mínimos. Disponível em http://www1.ibge.gov.br/ibge/estatistica/populacao/condicaodevida/indicadoresmini mos/conceitos.shtm. Acesso em: 11/03/02.

Síntese de Indicadores Sociais. Disponível em http://www2.ibge.gov.br/ibge/ftp/ftp.php?dir=/Indicadores Sociais/Síntese de Indic adores Sociais 2000. Acesso em: 11/03/02

. Sistema de contas nacionais - Brasil. Rio de Janeiro: Departamento de contas nacionais do IBGE, 1997.

IOSCHPE, Evelyn Berg. O balanço social das empresas. Folha de São Paulo. São Paulo: 01 abr. 1997.

IPARDES. Anuário estatístico do Estado do Paraná 2001. Paraná: 2001. Disponível em http://www.ipardes.gov.br/anuario2001 glossario.html. Acesso em: 13/02/02.

IUDÍCIBUS, Sérgio. Teoria da contabilidade. 6. ed. São Paulo: Atlas, 2000.

IUDÍCIBUS, Sérgio de, MARTINS, Eliseu, GELBCKE, Ernesto Rubens. Manual de contabilidade das sociedades por ações. 5 ed. São Paulo: Atlas, 2000.

KROETZ, César Eduardo Stevens. Balanço social, teoria e prática. São Paulo: Atlas, 2000.

LAPPONI, Juan Carlos. Estatística usando Excel 5 e 7. São Paulo: Lapponi Treinamento e editora, 1997.

LORES, Raul Juste. O que falta fazer. Revista Veja. São Paulo: 1709. 18 jul. 2.001. 
LUCAS, Fábio. Introdução ao estudo da repartição de renda. Belo Horizonte: Faculdade de ciências econômicas da Universidade de Minas Gerais, 1959.

MANFREDINI, Camila. Mais empresas publicam o balanço social. Gazeta Mercantil. São Paulo: 23 mar. 2001 p. A10

MANKIW, N. Gregory. Introdução à economia: princípios de micro e macroeconomia. Tradução Maria José Cyhlar Monteiro. 2. ed. Rio de Janeiro: Campus, 2001.

MARIANO, Rosimar Pereira. Elementos principais dos diferentes modelos propostos de balanço social. Pensar Contábil - Revista do Conselho Regional Contabilidade Estado Rio de Janeiro. Rio de Janeiro:, ano III, 27-32, nº 9, ago/out, 2000 .

MARTINS, Eliseu. Balanço social - idéia que merece permanecer. Gazeta Mercantil. São Paulo: 18 set. 1997, Caderno A, p. 3

Demonstração do valor adicionado - Alguns exemplos reais. IOB informações objetivas. São Paulo: TC boletim 31/97.

. Demonstração do valor adicionado de bancos. IOB Informações objetivas. São Paulo: TC boletim 30/97.

Uma nova demonstração contábil: a do valor adicionado. IOB informações objetivas. São Paulo: TC boletim 11/89.

Uma nova demonstração contábil no projeto de reforma da Lei das S/A: a do valor adicionado. IOB Informações objetivas. São Paulo: TC boletim $29 / 97$.

MARTINS, Gilberto de Andrade. Manual para elaboração de monografias e dissertações. 2. ed. São Paulo: Atlas, 2000.

MENDES, Abadia Eleuza, et al. Balanço social: exercício de cidadania. Revista de Contabilidade do CRC-SP. São Paulo: ano II, nº . 6, 76-82, nov. 1998.

PASTORE, José. A agonia do emprego. São Paulo: LTr, 1997.

CLT: o que pode e o que não pode ser negociado. Disponível em http://www.josepastore.com.br/artigos/relacoestrabalhistas/153.htm. Acesso em: 05/03/02.

Encargos sociais no Brasil: implicações para o salário, emprego e competitividade. São Paulo: LTr, 1997. 
_.Migração de empregos. Disponível em http://www.josepastore.com.br/artigos/relacoestrabalhistas/153.htm. Acesso em: 05/03/02.

PEROTONI, Marco Antonio. Balanço social: liberdade ou obrigatoriedade? Revista Brasileira de Contabilidade. Brasília: ano XXVII, nº . 110, 82, mar/abr. 1998.

Normas uniformes para o balanço social. Gazeta Mercantil. São Paulo: 25 set. 2001. p. A2.

PEROTONI, Marco Antonio, CUNHA, Aromildo Sprenger. Balanço social. Revista Brasileira de Contabilidade. Brasília: ano XXVI, nº . 104, 13-20, mar/abr. 1997.

PINHO, Diva Benevides, VASCONCELlOS, Marco A. Sandoval de (coord.). Manual de economia. 3. ed. São Paulo: Saraiva, 2001.

QUADROS, Waldir José de. ANTUNES, Davi José Nardy. Classes sociais e distribuição de renda dos anos noventa. Campinas: UNICAMP, n. 30, out. 2001. Disponível em http://www.eco.unicamp.br/publicacoes/textos/dowload/caderno.pdf. Acesso em: 11/03/02.

RIBEIRO, Maisa de Souza. Balanço social. Jornal do Economista, São Paulo: $n^{\circ}$. 122, 19 abr. 1999.

Balanço social. Revista Brasileira de Contabilidade. Brasília: $\mathrm{n}^{\circ}$. 115, 72-81, jan/fev. 1999.

RIBEIRO, Maísa de Souza, LISBOA, Lázaro Plácido. Balanço social: instrumento de divulgação da interação da empresa com a sociedade. In: Encontro da ANPAD, 23ํ, 1999, Rio de Janeiro. Anais..., 1999.

ROCHA, Sonia. Pobreza e desigualdade no Brasil: o esgotamento dos efeitos do Plano Real. Rio de Janeiro: IPEA, 2001 p. 2-3. (Texto para discussão $\mathrm{n}^{\mathbf{0}}$ 721). Disponível em http://www.ipea.gov.br/pub/td/td 2000/td0721.pdf. Acesso em: 11/03/02.

ROCHA, Wellington. Encargos sociais no Brasil antes e depois da Constituição Federal de 1988. Dissertação de mestrado - Faculdade de Economia e Contabilidade da Universidade de São Paulo. São Paulo: FEA/USP, 1991

RODRÍGUEZ, Alberto Almada. Quatro aspectos do levantamento da demonstração do valor adicionado nos setores públicos e privados. Revista Brasileira de Contabilidade. Brasília: ano XXIV, nº 62, 4460, mar/abr. 1996.

ROSSETTI, José Paschoal. Introdução à economia. 6. ed. São Paulo: Atlas, 1995.

SANDRONI, Paulo. (Org.) Novíssimo dicionário de economia. 6. ed. São Paulo: Best Seller, 2001. 
SANTOS, Ariovaldo dos. Demonstração contábil do valor adicionado- DVA- Um instrumento para medição da geração e distribuição de riqueza das empresas. Tese de Livre Docência - Faculdade de Economia e Contabilidade da Universidade de São Paulo. São Paulo: FEA/USP, 1999.

Demonstração de Resultados X Demonstração de Valor Adicionado. Anefac news. São Paulo:, ano I, nº 02, 3-4, maio 2001.

SANTOS, Ariovaldo dos, CARVALHO, L. Nelson. Balanço social, um indicador de excelência. Revista Exame. São Paulo: V. 31, nº . 19, 139, set. 1997.

SANTOS, Ariovaldo dos, FREIRE, Fátima S., MALO, François Bernard. O balanço social no Brasil: gênese, finalidade e implementação como complemento às demonstrações contábeis. In: Encontro da ANPAD, 23ㅜ, 1998, Foz do Iguaçu.Anais..., 1998.

SANTOS, Ariovaldo dos, LUSTOSA, Paulo Roberto B. Proposta de um modelo de DVA - Demonstração do Valor Adicionado - adequado ao novo desenho institucional e mercantil do setor elétrico brasileiro. São Paulo: Fundação Instituto de Pesquisa Econômica - FIPE, 1998.

SANTOS, Ariovaldo dos. PARMEZZANO, Cláudia Meca. Demonstração do valor adicionado - dois casos muito especiais. IOB informações objetivas. São Paulo: boletim TC $1 / 99$.

objetivas . São Paulo: boletim TC 49/99.

SANTOS, Hermes Mendes. ALMEIDA, Martinho Isnard Ribeiro de. Novos fatores geradores de riqueza na era do conhecimento: uma proposição estratégica. In: SEMEAD, V, 2001, São Paulo, Anais..., 2001.

SANTOS, Raul Cristóvão dos. Divisão do trabalho e capital na riqueza das nações. São Paulo: Instituto de Pesquisa Econômica - IPE/ Universidade de São Paulo - USP, 1995. (Programa de Seminários Acadêmicos, 21/95).

Riqueza e ciência econômica. São Paulo: Instituto de Pesquisa Econômica - IPE/ Universidade de São Paulo - USP, 1986. (Texto de discussão. Relatório Técnico).

$\overline{\text { jul.99. }}$

Riqueza e trabalho. São Paulo: Informações FIPE, n. 226, p. 20-23,

SÃO PAULO. Resolução 05/98 da Câmara Municipal da Cidade de São Paulo. Cria o dia e o selo da Empresa Cidadã às empresas que apresentarem qualidade em seu balanço social e dá outras providências. 
SCHARF, Regina. Balanço social identifica empresas. Gazeta Mercantil. São Paulo: 22 ago. 2001, p. A6.

SELDON, Arthur, PENNANCE, F. G. Dicionário de economia. Tradução Nelson de Vicenzi. 2. ed. Rio de Janeiro: Bloch, 1975.

SEMINÁRIO BALANÇO SOCIAL: CIDADANIA E TRANSPARÊNCIA PÚBLICA DAS EMPRESAS. 1998, Rio de Janeiro. Apostila... Rio de Janeiro: Instituto Brasileiro de Análises Sociais e Econômicas - IBASE, 1998.

SEMINÁRIO BALANÇO SOCIAL - UMA IDÉIA VIVA (3․ GRUPO). 1997, São Paulo. Apostila... São Paulo: JCA Treinamentos e FIPECAFI - FEA/USP, 1997.

SEMINÁRIO MERCADO DE CAPITAIS E O BALANÇO SOCIAL. 2001, São Paulo. Apostila... São Paulo: ABAMEC, 2001.

SIMONSEN, Mário Henrique. Macroeconomia. Rio de Janeiro: Apec, V. I, 1975

SINGER, Paul. Dominação e desigualdade: estrutura de classes e repartição de renda no Brasil. Rio de Janeiro: Paz e Terra, 1981

SILVA, César Augusto Tibúrcio, FREIRE, Fátima de Souza (org.). Balanço social: teoria e prática. São Paulo: Atlas, 2001.

SMITH, Adam. A riqueza das nações: investigação sobre sua natureza e suas causas. Tradução Luiz João Baraúna. São Paulo: Abril Cultural, 1983, Vol. I.

SOUZA, Herbert de. Balanço social: voluntário ou obrigatório? Folha de São Paulo. São Paulo: 07 abr. 1997, Caderno I.

1997, p. 2.

Empresa pública e cidadã. Folha de São Paulo. São Paulo: 26 mar.

STAUBER, Elza. Uma contribuição à elaboração da demonstração de valor adicionado aplicado nas instituições de ensino superior: uma abordagem social. Tese de doutoramento. Universidade Presbiteriana Mackenzie. São Paulo: Universidade Presbiteriana Mackenzie, 2001.

STEVENSON, Willian J. Estatística aplicada à administração. São Paulo: Harbra, 1981.

SUPLICY, Marta. O que é balanço social? Folha de São Paulo. São Paulo: 10 jun. 1997.

SUSSEKIND, Arnaldo. MARANHÃO, Délio. VIANNA, Segadas. Instituições de Direito do Trabalho. 14. ed. São Paulo: LTD, 1993. v. 1 e 2. 
TINOCO, João Eduardo Prudêncio. Balanço social - Uma abordagem sócioeconômica da contabilidade. Dissertação de mestrado - Faculdade de Economia e Administração da Universidade de São Paulo. São Paulo: FEA/USP, 1984.

TRIBUNAL SUPERIOR DO TRABALHO. Proteção do trabalhador. Disponível em http://www.tst.gov.br/ASCS/historia1.htm Acesso em: 05/03/02.

UNDURRAGA, Eduardo. Seminário responsabilidad social de la empresa y balance social. Organizacion Internacional del Trabajo. Lima: 1995.

WONNACOTT, P., WONNACOTT, R. Introdução à economia. Tradução Nuno Renan L. F. Pinto et al. São Paulo: McGraw-Hill do Brasil, 1985.

YOSHIOCA, Ricardo. Valor adicionado - Alguns conceitos econômicos que ajudam a entender a demonstração contábil. IOB informações objetivas. São Paulo: boletim TC 08/98.

YOUNG, Ricardo. Balanço social é responsabilidade do governo. Folha de São Paulo. São Paulo: 29 mar. 1997. 
ANEXOS 
Anexo A - Modelo de balanço social francês 
Anexo B - Modelo de balanço social chileno 
Anexo C - Modelo de balanço social belga 
Anexo D - Modelo de balanço social português 
Apêndices 
Apêndice A - Quadros e tabelas 